\title{
A DIALOGUE BETWEEN
}

REASON AND ADVERSITY

F. N. M. DIEKSTRA 
A DIALOGUE BETWEEN REASON

AND ADVERSITY 
PROMOTOR: PROFESSOR DR. G. STORMS 


\title{
A DIALOGUE BETWEEN \\ REASON AND ADVERSITY
}

\author{
A LATE MIDDLE ENGLISH VERSION OF PETRARCH'S \\ DE REMEDIIS
}

\begin{abstract}
EDITED FROM MS. II VI.39 OF THE UNIVERSITY LIBRARY, CAMBRIDGE WITH AN INTRODUCTION,
\end{abstract} NOTES AND GLOSSARY AND THE ORIGINAL LATIN TEXT

\section{PROEFSCHRIFT}

ter verkrijging van de graad van doctor in de letteren aan de katholieke universiteit te Nijmegen, op gezag van de rector magnificus Dr A Th L. M Mertens, hoogleraar in de faculteit der geneeskunde, volgens besluit van de senaat in het openbaar te verdedigen op 8 maart 1968, des namiddags te vier uur, door FRANCISCUS NICOLAAS MARIA DIEKSTRA geboren te Groningen

Te Assen bij

VAN GORCUM \& COMP N V. - DR. H. J. PRAKKE\& H. M. G. PRAKKE 
The publication of this work was made possible through a grant from the Netherlands Organization for the Advancement of Pure Research (Z.W.O.). 
To my wife
To my parents 

LIST OF ABBREVIATIONS. . . . . . . . . . . XXI

INTRODUCTION . . . . . . . . . . . . . . [1]

A. The Manuscript. . . . . . . . . . . . . . . . . . [3]

a. Description of the MS. . . . . . . . . . [3]

b. Use of the Volume, Provenance and Date . . . . . [8]

c. Note on the Letter Shapes. . . . . . . . . . . . . [11]

d. Punctuation Marks . . . . . . . . . . . . . . . . [12]

e. Editorial Practice. . . . . . . . . . . . . [13]

B. Sources of the Text. . . . . . . . . . . . . . . . [15]

I. Petrarch's De Remediis Utriusque Fortunae . . . . . [15]

a. Nature of Petrarch's Work. . . . . . . . . . [16]

b. The De Remediis a Humanistic Influence? Its Reception in England and on the Continent in the 14th and 15th Centuries. . . . . . . . . . . . . [19]

c. The Translation and its Relation to the Original . . [32]

II. Seneca's De Remediis Fortuitorum . . . . . . . . . [35]

III. Boethius' De Consolatione Philosophiae . . . . . . . [37]

C. Literary Genre and Theme. . . . . . . . . . . . . . . [38]

a. The Dialogue Form. . . . . . . . . . . [38]

b. The Interlocutors. . . . . . . . . . . . . . . [42] 
1. The Four Affections. . . . . . . . . [42]

2. The Figure of Ratio . . . . . . . . . . [43]

c. The 'Consolatio' . . . . . . . . . . . . [ [46]

d. The Goods of Nature, of Fortune and of Grace . . . [51]

e. The Happy Humanist and his Preoccupation with Misery: Petrarch's De Remediis and the Contemptus Mundi Literature. . . . . . . . . . [53]

THE TWO TEXTS PARALLEL .............. . . 1

A. A Dialogue between Reason and Adversity. . . . . . . . 1

B. Petrarch's De Remediis Utriusque Fortunae, Book II, Dialogues I-XI and Boethius' De Consolatione Philosophiae, Book II, Prose II . . . . . . . . . . . . 1 NOTES. . . . . . . . . . . . . . . 4 42

LANGUAGE. . . . . . . . . . . . . . . . 53

a. Accidence. . . . . . . . . . . . . 53

b. Phonology. . . . . . . . . . . . . . . 56

c. Vocabulary . . . . . . . . . . . . . . 64

d. Localization of the Dialect. . . . . . . . . . . 65

e. Style and Proverbs. . . . . . . . . . . . . . . . 70

f. Points of Syntax. . . . . . . . . . . 80

LIST OF WORKS CITED. . . . . . . . . . . . . . 115

GLOSSARY . . . . . . . . . . . . . 122

GLOSSARY OF PROPER NAMES . . . . . . . . . . 155

INDEX . . . . . . . . . . . . . . 156 


\section{PREFACE}

Of the treatise edited in this work there are no earlier editions. It has passed unnoticed in a single version in MS. Ii.VI.39 in the University Library, Cambridge, which is mainly known for its version of the Cloud of Unknowing.

In an article in Dominican Studies, I (1948) Dr. Doyle of Durham University had noted it in passing as a unique little piece in a collection for religious with contemplative interests. He suggested to me the editing of this treatise, which seemed promising from the point of view of language and style. It is full of proverbs, maxims and terse phrases, which mark it out as one of the more lively items among the common run of Middle English devotional texts, though it has no special literary distinction.

After some time I found that the treatise was an adaptation of part of Petrarch's Latin treatise De Remediis Utriusque Fortunae, which made it worth-while to study the nature of the early reception of this Petrarch text in England and the wider issue of the impact of humanistic writing on the later Middle Ages. Apart from Chaucer's use of Petrarch in the Clerk's Tale and the Canticus Troili this is the earliest adaptation of any of Petrarch's works in England.

I have attempted to pay equal attention to the literary affiliations and to the linguistic features of the treatise. The introduction includes a discussion of the sources, the literary genres of dialogue and consolatio and a discussion of Petrarch's reception in England in the 14th and 15 th centuries. In the language section I have paid especial attention to syntax and style. The glossary aims at completeness.

My deepest debt of gratitude is that to Dr. Doyle, who suggested the subject and provided leads and information at several stages of the work. My acknowledgements are also due to Professor McIntosh of 
Edinburgh University and to Professor Samuels of Glasgow University for their generous help with the dialectal intricacies. It is further a pleasure to thank Professor Dobson of Jesus College, Oxford and Professor Roberto Weiss of University College, London for answering some of my queries.

As for financial help I wish to express my thanks to the Netherlands Organization for the Advancement of Pure Research (Z.W.O.) for a grant enabling me to do part of my research in English libraries, and for a grant covering the costs of publication. Finally I wish to thank the Curators of the University of Nijmegen for leave from teaching duties during my stay in England.

The promptness and accuracy of Dr. F. Aarts and Drs. P. v. d. Eeden in reading the proofs have been a great help. 


\title{
ABBREVIATIONS
}

\author{
AF \\ Anglo-French \\ Angl. \\ Anglian \\ Bohn \\ H G Bohn, A Hand-Book of Proverbs, London, 1855 \\ $\mathrm{CF}$ \\ Central French \\ CHEL \\ Cambridge History of English Literature \\ CMS \\ Central Midland Standard \\ De Cons. \\ De Consolatione Phılosophiae \\ D R F \\ De Remedis Fortuitorum \\ Du \\ Dutch \\ Ecclus. \\ Ecclesiasticus \\ E.E.T.S. E.S \\ Early English Text Society, Extra Senes \\ E E.T.S. O.S \\ Early Englısh Text Society, Orıgınal Serıes \\ EME \\ ep \\ Early Muddle English \\ epistula \\ Ep.Mor. \\ F \\ Epistulae Morales \\ French \\ Fl.Doct. \\ It \\ Flores Doctorum by Thomas Palmeranus \\ MS I1 VI 39 in University Library, Cambridge \\ Jordan \\ L \\ LOE \\ Luick \\ LV \\ ME \\ MED \\ $\mathrm{R}$ Jordan, Handbuch der mittelenglischen Grammat $k$, I Te1l: \\ Lautlehre, Heidelberg, 1925 Zweite verb Aufl. by $\mathrm{H} \mathrm{Chr}$ \\ Matthes, Heidelberg, 1934 \\ Latin \\ Late Old English \\ $\mathrm{K}$ Luick, Historische Grammatik der englischen Sprache, \\ Lelpzig, 1914-40 (repr Oxford-Stuttgart, 1964) \\ Later Version \\ Middle English \\ A Middle English Dictzonary by F. $\mathrm{H}$ Stratmann, new ed. by \\ H Bradley, Oxford, 1891 \\ Migne J. P. Migne, ed Patrologıa Latina \\ ML \\ MMED \\ Medieval Latın \\ Michigan .Middle English Dictionary, ed $\mathrm{H}$ Kurath and S. M \\ Kuhn, 1952- \\ Must. \\ T F. Mustanoja, A Middle English Syntax, Helsınkı, 1960
}


ODP

OE

OED

OF

OI

OIr

ON

ONF

P L

RES

SATF

$\mathbf{t}, \mathbf{T}$

TPS

ULC

Ven

Visser, $H S$

Visser, More

WS

Yrksh Wr
Oxford Dictionary of English Proverbs, ed W G Smith, 2nd rev ed by Sur Paul Harvey, Oxford, 1952

Old English

Oxford English Dictionary

Old French

Old Icelandic

Old Irish

Old Norse

Old Northern French

Patrologia Latina

Review of English Studies

Société des Anciens Textes França1s

tome

Transactions of the Philological Society

University Library, Cambridge

The Venice edition of Petrarch's Latın Works, 1501

F Th Visser, An Historical Syntax of the English Language, Parts I and II, Lelden, 1963 and 1966

$\mathrm{F}$ Th Visser, A Syntax of the Language of St Thomas More, Parts I-III Louvain, 1946-56

West Saxon

Yorkshire Writers, ed C Horstmann, 2 vols , London, 1895 
INTRODUCTION 



\section{A. THE MANUSCRIPT}

\section{A. DESCRIPTION OF THE MANUSCRIPT}

In the Catalogue of the Manuscripts preserved in the Library of the University of Cambridge the treatise edited here is described as: 'A dialogue, in English, unfinished. On the Evils of Life, between Adversite and Resoun'. As the text has no title in the MS, I have decided to refer to it as $A$ Dialogue between Reason and Adversity.

The treatise is, as far as I have been able to ascertain, unique and is extant in MS. Ii.VI.39 of the University Library, Cambridge. This MS is a duodecimo on parchment, originally in paper boards, but since 1935 bound in two volumes and is entitled Varia Theologica ${ }^{1}$. It is made up of several sections of the same small dimensions $(5 \times 3$ ins.) but of varying dates ranging from the 13 th to the 15 th centuries and of no necessary connection. The treatises on leaves $67-188$, however, belong together and contain the work of contemplative religious compilers. This portion, in which the Dialogue comprises ff. $177^{\mathrm{b}}$ $188^{\text {b }}$, is written in a small and neat hand of the early fifteenth century ${ }^{2}$ which Dr. Doyle describes as a 'cursiva (anglicana) formata'. See p. [11]. Nothing is known of the history of the MS before it came to the University Library of Cambridge in 1715 with the Moore Collection,

1 Apart from the description in the ULC Catalogue of MSS, a draft description in the handwriting of M. $R$. James is available in the MS Room of Cambridge University Library. Part of the contents - ff. 67-188 - have been described by Dr. A. I. Doyle, 'A Prayer attributed to St. Thomas Aquinas', Dominican Studies, Vol. I (July 1948), 229-238.

- According to Dr Doyle, art. cit., p. 232 and Ph. Hodgson, The Cloud of Unknowing, E.E.T.S. 218, p. xiii, note; late fourteenth according to Horstmann, Yrksh.Wr. I, p. 162 and Helen Gardner, RES, IX, p. 145. 
in which it is no. $126^{1}$. Nor is anything known about the time when the several sections were put together.

There are 248 leaves, gathered in eights. Various leaves are missing: the second quire of section III lacks 1-7, section VII lacks 1-2, section IX lacks one folio. The lines to a page vary from 26-32, written in single columns. Paragraph marks are in blue and red with conventional filigree work.

CONTENTS: Four flyleaves from a book of lecture notes, probably logical or mathematical, almost illegible (14th century?).

\section{Section I}

1. ff. 5-64. LIBER PLATEARII, de Passionibus et eorum curis, in an early 13th-century hand. Begins: 'Amicum induit'... ends: ...' fistule truncatur'. Printed at Venice: Joannes Platearius, Expositio in Antidotorium, 1589. On ff. 65 and 66 receipts in several hands; a list of medical terms in three columns; a charm to stanch blood. At the bottom of fol. $66^{\mathrm{a}}$ is written in a fifteenth-century hand magister iohannes clastun, magistri mei and on fol. $66^{\mathrm{b}}$ petri durant; at the bottom of fol. $67^{\mathrm{a}}$ is written ser thomas colman in an early 16th-century hand. Only the last name belongs to the portion of the MS that contains the Dialogue.

\section{Section II}

2. ff. 67-71. The beginning of the MANIPULUS FLORUM or Flores Doctorum of Thomas de Hibernia (Thomas Palmeranus), a collection of wise sayings excerpted from patristic and classical authors and arranged under alphabetical headings: abstinentia, abusio, acceptio personarum, accidia, adjutorium, adventus, adulatio, etc. This extract stops at amor. Though the arrangement and most of the items are obviously based on Thomas Palmer's work, there are some entries which must have been incorporated later. Thus under accidia there is a quotation from Suso's Horologium Sapientiae which the thirteenthcentury Thomas Palmer cannot have known. First printed in Venice, 1550 and frequently since.

3. ff. 71-74. A TRETIS OF MAYNDENHOD. Begins: 'Sister we

1 E. Bernard, Catalogi Librorum Manuscriptorum Angliae et Hiberniae, Oxford, 1697, no. 9312 (Vol. II, pt. 1, p. 364). 
greten zow of inward herte'... ends: .... 'charite wip long abidingnes'. This is also extant in ULC MS Ii.VI.55 (there addressed to a 'suster in crist').

\section{Section III}

4. ff. 75-120b. Here begynnyth a bok of contemplacioun the wich is clepid DE CLOWDE OF VNKNOWYNG in pe wich a souzle is oned with God. One of the earliest copies and according to the latest editor, $\mathrm{Ph}$. Hodgson, closely related to and perhaps copied from MS. Harley 674, the basis of the critical edition. Begins: 'God vnto wom alle hertes ben open'... ; ends: ... 'of contemplacioun, deo gr.'

5. ff. $120^{\mathrm{b}}-122^{\mathrm{b}}$. Here beginnep A SERMOUN OF SEYNT AUSTIN how man is maad to pe ymage of pe liknes of god his makere. A translation of a pseudo-Augustine sermon printed by Migne among the works of St. Ambrose under the title: De Dignitate Conditionis Humane (T. XVII, col. 1105-1108) but also known under the title De Creatione and De Imagine et Similitudine. The sermon also appears in ULC Ii. VI.55 and Harley 2330 (both early 15th century) and is related, together with three other pseudo-Augustine treatises, to the Wycliftite Scriptural translations, according to Dr. S. L. Fristedt, The Wycliffe Bible, Part I, Stockholm, 1953, pp. 43 ff.

6. ff. 122-133. Here beginnep a book pat Richard of Seynt Victore maad vp pe historie of Joseph \& of his XII sones and is callid BENIAMYN. This is an abridged version of Richard of St. Victor's Benjamin Minor. ${ }^{1}$ At the foot of fol. 133 and continuing half way down the verso, a copy of the first third of a prayer attributed to Thomas Aquinas, abandoned by the scribe when he saw he could not fit it all on the same quire, and written in full ff. 163-165. Begins: 'O pou merciful lord god I beseche pe'...; ends: '... and in my trespassing'.

\section{Section IV}

7. ff. 134-157. HUGO DE CONSCIENCIA. This is an extract, the beginning and the end coinciding with the original, of the third book

1 ed. C. Horstmann, op. cit. I, pp. 162-172 and modernized by J. E. G. Gardner, The Cell of Selt-Knowledge, 1925, pp. 3-33. Ed. Ph. Hodgson, Deonise Hid Diuinite, etc., E.E.T.S., O.S. 231, pp. $12 \mathrm{ff}$. The Latin text is in Migne T.CXCVI. 
of Hugo of St. Victor's De Anima, printed in Migne among the works of St. Bernard of Clairvaux under the title: De Interiori Domo sen de Consciencia Aedificanda. (T. CLXXXIV, col. 507) Begins: 'Domus hec in qua habitamus'...; ends: .... 'quam terrestrium occupacione'. At the foot of fol. 157 in the same hand, very minute, part of an English poem on the sixteen points of Charity, extant in one other MS. ${ }^{1}$ Begins: 'Man among pi mirpe pis haue in mynde'... ends: '....as me wantip charite'. On f. $144^{b}$ there is a 16 th or 17 th-century inscription 'Simon Ball is the oner of this'.

\section{Section V}

8. ff. 158-162. SANCTUS ALREDUS DE VERA AMICICIA. An adaptation of the third book of Aelred of Rievaulx's dialogue $D e$ Spiritali Amicitia (Migne, T. CXCV, col. 659), long attributed to St. Augustine, which may have been the main reason for its medieval popularity. The dialogue as it is preserved in Ii.VI.39 is also extant in Trinity College, Dublin, MS 432 (D. 4.18), ff. 134-136 and has been edited by A. Hoste, Cîteaux, X, 1959, pp. 268-276. Begins: 'est enim ait regressus ad amicum'... ends: ...'cum deus fuerit omnia in omnibus'.

9. ff. $162^{\text {b }}-163^{\text {b }}$. BERNARDUS DE DIGNITATE SACERDOTUM. Not by St. Bernard but by a Brother Bernard of the late 13th century at earliest (cf. The Threefold Gift of Christ by Brother Bernard. Transl. \& ed. by a religious of C.S.M.V., London, 1954). Begins: 'O quantum dignitatem contulit vobis deus'; ends: .... 'omnibus dico vigilate. etc.'

10. ff. $163^{\mathrm{b}}-165$. ORATIO THOME DE ALQUIN (in English), a translation of a Latin prayer attributed to Thomas Aquinas which enjoyed considerable vogue beyond the Middle Ages. Ed. by Dr. A. I. Doyle (see above) who prints the Latin and the English text. Begins: 'O pouz merciful lord god'... ends: ... of gladnesse pat neuere schal haue ende. Amen'.

\section{Section VI}

\section{1. ff. 166-177. LIBER DE DOCTRINA DICENDI ET TACENDI}

1 MS. Lambeth 853, ed. F. J. Furnivall, Hymns to the Virgin \& Christ, etc. E.E.T.S., 1867, pp. 114-117. 


\section{A. THE MANUSCRIPT}

ab Albertano Causidico Brissiensi de hora sancte agathe compositus et comprlatus. Begins: 'Inicio et medio ac fine mei tractatus...' Ends: ....'ad eterna gaudia nos faciat peruenire, amen'. This is only the first book. The whole treatise was printed for the first time in 1490 and frequently since.

12. ff. $177^{\mathrm{b}}-188^{\mathrm{b}}$. A DIALOGUE BETWEEN REASON AND ADVERSITY edited below. Fol. $179^{\mathrm{b}}$ has later scribbles in English: 'And for me in the name of god amen'. The same occurs on fol. 189.

\section{Section VII}

13. ff. 190-196. In another hand. SCALA CLAUSTRALIUM que dicitur Scala Celi Auctore Adamo Carthusiensi (the latter words added by Bishop Tanner). Ascribed variously to St. Augustine and St. Bernard, but now generally ascribed to Guigo II, prior of Grande Chartreuse, who wrote it shortly after 1150 . Printed by Migne among the works of St. Bernard under the above title and in the Appendix Volume to the works of St. Augustine under the title Scala Paradisi. ${ }^{1}$ Begins: 'Cum die quadam corporali manuum labore'... ends: ...'delicatus est. sponsus est. nobilis est'. This is immediately followed on fol. 196 by a prayer beginning: 'Domine sancte pater eterne deus propter tuam largitatem'.... and one beginning: 'Omnibus consideratis'. On fol. 197 follows a rhythmical prayer beginning: 'O crux frutex saluificus vino fonte rigatus'... ends: .. 'eterne vite status. Amen'. This occurs also in MS. Thornton, ed. Horstmann, Yrksh. Wr. I, p. 382, there ascribed to St. Bonaventura. ${ }^{2}$

\section{Section VIII}

14. ff. 198-213. TRACTATUS DE XII UTILITATIBUS TRI$B U L A C I O N I S$. Ascribed by Tanner to Adam Scotus of Dryburgh but printed by Migne among the works of Peter of Blois (T. CCVII, col. 989)..$^{3}$

1 It is also extant in a ME version in three 15th-century MSS entitled $A$ Ladder of Foure Ronges in MS I1 VI 33, MS Douce 322, and MS Harley 1706; cf. Appendix B to Ph Hodgson's edition of Deonise Hid Diurnite, E E T S O S 231.

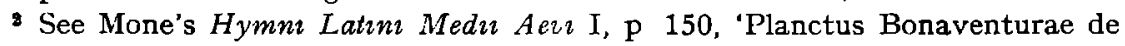
Christo'

3 For the English version from MS Rawl C 894 cf Horstmann, Yrksh Wr II, pp $391-406$ 
On fol. $213^{\mathrm{b}}$ follows a hymn to the Virgin beginning: 'Sponsa ioseph...' Fol. 214b-217 are blank but for scribbles.

\section{Section IX}

15. ff. $218-240$. In a late 12 th or early 13 th-century hand HIERONYMUS CONTRA IOUINIANUM. Begins: 'Satis habundeque christiane pudicicie'... ends: .... 'omnia vincit amor et nos cedamus amori'. Containing Lib. I, capp. 41-49; Lib. II, capp. 6-14; Lib. I, cap. 28; Lib. II, ult. cap. The treatise is printed in Migne, P.L., t. XXIII, col. $211 \mathrm{ff}$.

Some notes in a 13th-century hand follow on fol. $240^{\mathrm{b}}$, among which the explanation of the word Rome.

\section{Section $\mathbf{X}$}

Then seven leaves in various hands and two flyleaves. Fol. 241. The Miracle of St. Augustine at Compton. Begins: 'In pago oxenfordensi est villa cummeton (VI m. dist. a wudestok)'. Ed. Horstmann, Nova Legenda Anglie, I, p. 100 (abridged from Joh. Brompton's Chronicon).

Fol. $241^{\mathrm{b}}$ has instructive notes, ' $\mathrm{Si}$ vis scire qualiter hore diei cognoscuntur' and others. Fol. 242. Gloss on the Gospel of St. John: 'In principio erat verbum'. Fol. 243. Another gloss: 'Cum audieritis prelia et sediciones'. Fol. 243b. Stories and notes for sermons. Fol. 244a-b. A list of Latin words used in two or more senses. Begins: 'Augustus. ti. to. cesar uel mensis habeto'... ends: ... 'est bubo uolucris. est morbus bubo sub auo apostema'. On the same fol.: 'Femineis uerbis nec equo qui pascitur herbis', etc. With French equivalent: 'Chiual pu de regaine e a parole feminine'. At the bottom a distich on the Herods." Fol. 245. Gloss on the Apocalypse of St. John: 'Signum magnum apparuit in celo', etc. Fol. 245b: On the masses on Christmas Day: 'Sacerdos in die natalis ter celebrat'... Then a reference to the Dial of Ahaz and half way down the folio a sermon: 'Rex est hodie et cras moritur'... continuing up to $248^{\text {b }}$.

\section{B, USE OF THE VOLUME, PROVENANCE AND DATE}

As has been noted above, the sections of the MS are of different dates and the binding together of the various portions may have been

1 Also in MS. Arundel 507, ed. Horstmann, Yrksh.Wr. I, p. 424. 


\section{A. THE MANUSCRIPT}

determined mainly by the similar small size of the leaves. ${ }^{1}$ But the above survey of the contents at any rate shows that part of the MS formed quite a typical collection for religious with contemplative interests. ${ }^{2}$ The portion in the one hand suggests contemplative religious compilers and the other 14th and 15th-century Latin portions (the Scala Claustralium and De xii Utilitatibus Tribulationis) confirm this impression. $^{3} \quad$ As to the original ownership, the nature of some of the treatises, especially the Cloud, Benjamin Minor and the Scala Claustralium, suggests a religious house rather than seculars, but by the sixteenth century the ownership may have changed. The names 'magister iohannes clastun' and 'ser thomas colman' show at least clerical use of the volume, as one might expect. ('Ser', which is the English for 'Dominus', was used of secular priests, 'Magister' might be a religious).

The English sermon of Augustine (No. 5) is from a translator who had also been engaged on the Wycliffite Bible translations (see above, p. [5]). This is no evidence of unorthodoxy on the part of the owners. The presence of the Cloud and Benjamin Minor is equally significant of their tastes and sources. In the Dialogue the bible quotations do not show dependence on the Wycliffite translations.

As we shall see, the inclusion of the Dialogue in this volume, in spite of its 'humanistic' source, is no exception to the pronounced devotional character of the rest of the treatises. The abrupt ending of the text would suggest that the copyist had a fuller version in front of him. On the other hand, most of the treatises in the MS are extracts or compilations and Petrarch's treatise may never have been completely translated. One explanation of its unfinished state might be found in the nature of the topics discussed by Petrarch in the sections immediately following the point where the scribe ${ }^{4}$ stopped. These subjects-the heavy burden of a large family, money problems, gambling, law-suits, the burden of unchaste, barren and ill-tempered wives - would evidently be out of place in this collection.

1 E. Ph. Goldschmidt, Medieval Texts and their First Appearance in Print, London, 1943, p. 95, observes that the prime consideration in the binding of MSS was the size of the leaves, next that of subject-matter.

2 The tretis of maydenhod is addressed to women religious.

a The format of the volume is that of a small prayerbook and would have enabled the owner to carry it easily with him.

- but not necessarily the author. 
As for provenance, the MS affords no other clue than the names inscribed on fol. $66^{\mathrm{a}}, 66^{\mathrm{b}}, 67^{\mathrm{a}}$ and $144^{\mathrm{b}}$, which do not seem to be definitely identifiable. Only the names of Thomas Colman and Simon Ball occur in the portion that contains the Dialogue, the former in a sixteenth-century hand, the latter in a 16th or 17th-century hand. There was an early 14th-century Cambridge master by the name of Johannes Clastun, which is too early, and two in Alumni Cantabrigienses, ed. Venn, with the name Thomas Colman, both from Peterborough. One was a priest at Peterborough who was buried in 1589 at Cambridge, the other was ordained deacon at Peterborough and was rector of Brent Eleigh, Suffolk from 1625-42. These would fit the right area, roughly, which the analysis of the language indicates, but are on the late side. Emden lists two Cambridge graduates by the name of Colman, who are of approximately the right period. One, who as Emden notes was possibly the same as Th. Colman, was bachelor of canon and civil law and was vicar of Herne Hill, Kent till 1514 and vicar of S. Nicholas at Wade, Kent from 1514 till his death in 1517. The other Colman-whose Christian name is not known-was admitted to Cambridge in 1497. Peter Durant does not occur in the lists of Oxford and Cambridge graduates by Venn and Emden. The D.N.B. too, is silent about Simon Ball. The analysis of the language offers no obvious location either and even then it should be remembered that a well-defined type of language might be used by a scribe working elsewhere in the country. The ownership of Bishop Moore would fit the Eastern English provenance which the language suggests, since he was bishop of Norwich and other books of his are from that half of the country.

In default of any internal or external evidence in the text or the rest of the MS that might point to a particular author, no suggestion can be made as to authorship. It seems reasonable, however, to assume that he was a religious.

The date when Petrarch finished his De Remediis is quite exactly known: 4 October 1366. ${ }^{1}$ The date of MS.Ii.VI.39 is given variously as late fourteenth or early fifteenth century (see above p. [3]). According to Dr. Doyle the testimony of the handwriting, especially the simple $a$ and the occasional use in the MS of a secretary $s-a$ new form of continental origin, not the usual sigma shape-seems to support early

I See E. H. Wilkins, Petrarch's Later Years, Cambridge, Mass., 1959, p. 108. 



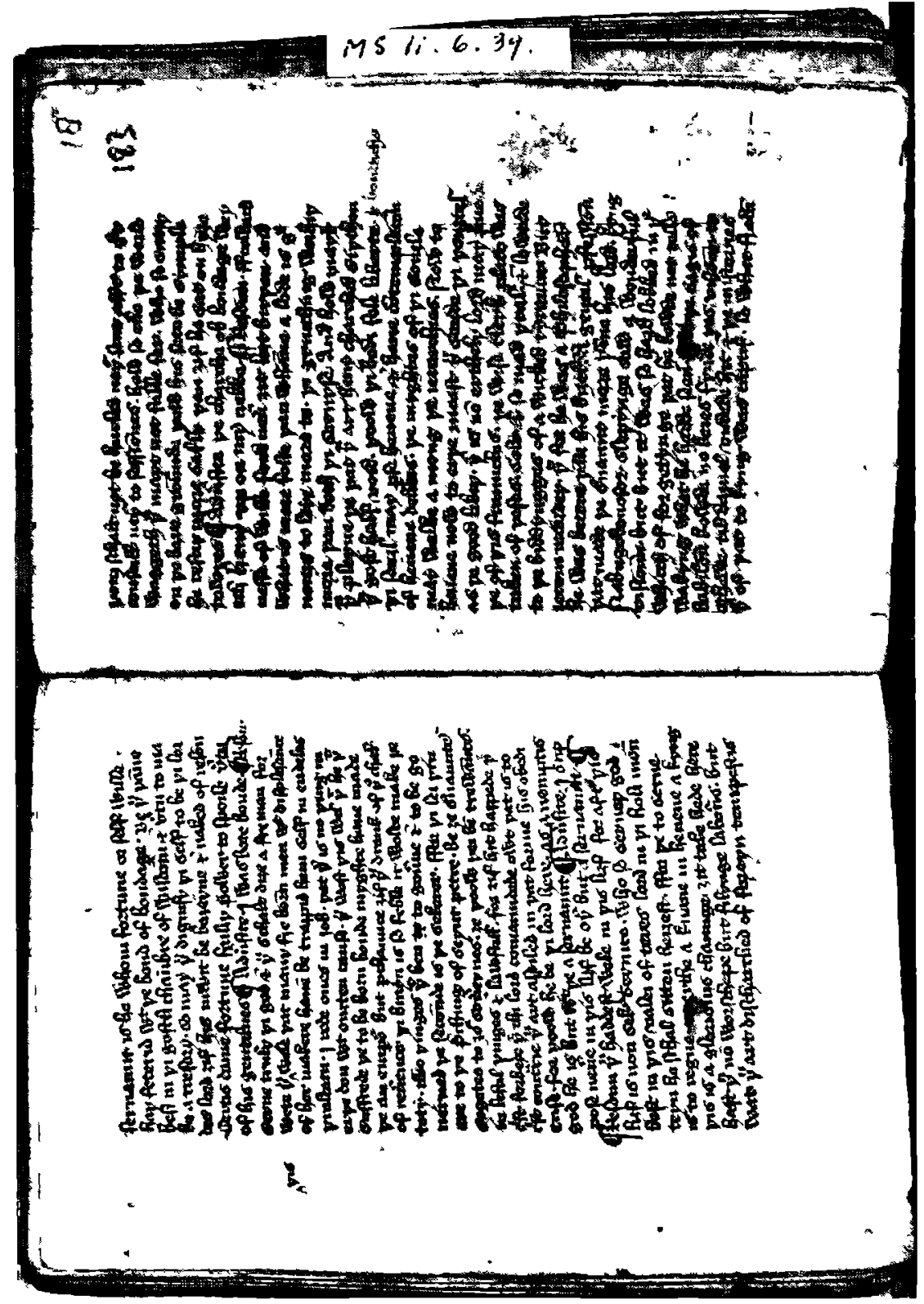

MS $11 \mathrm{VI} 39$, fol $182^{\mathrm{b}}$ and 183 , 


\section{A. THE MANUSCRIPT}

fifteenth rather than late fourteenth century. Indirect evidence can be derived from Miss Hodgson's assertion that the Cloud of Unknowing in MS. Harley 674 (early 15th century) was the model for the Cloud in our MS. As this version of the Cloud was written by the same scribe who wrote the Dialogue, the latter must surely be later than 1400 . However, these datings are based on examination of the script only without corroboration from other evidence, and one generally has to allow a possibility of a third of a century of error owing to the length of a scribe's career. The language, too, has some fifteenth-century developments and I would prefer to settle on a date in the first quarter of the fifteenth century.

\section{NOTE ON THE LETTER SHAPES}

N.B. Line references are to the reproduction of fol. $182^{\mathrm{b}}$ and $183^{\mathrm{s}}$ of the MS.

The hand is described by Dr. Doyle as a 'cursiva (anglicana) formata', with-mainly-unlooped uncial $d$, secretary $s$ as well as sigma $s$ finally and-mainly-simple $a$. The retention of looped $b, h, k, l$, long $f$ and $s$ and other features make this still basically a cursive script, but it is written with a degree of care, separating and stiffening of many letters which grades it as formalized. In the older nomenclature it would be called a 'semi-cursive' script.

Apart from capital A $\left(182^{b} / 7\right)$ there are two shapes of the letter $a$ namely the simple $a\left(182^{b} / 1\right)$, which is used almost throughout, and the occasional a (not found on the reproduction but it occurs e.g. on 185b/11).

There are three types of $s$, the long $s\left(182^{b} / 1\right)$ and, in final position, the usual sigma shape $\left(182^{b} / 1\right)$ which occasionally alternates with the secretary $s$ which looks like an 8 . This latter variety is not exemplified in the Dialogue, but it occurs in the Latin treatises, e.g. ff. 134 and 158. Note also the final $s$ at the end of $182^{b} / 18$ and 19.

There are three types of $r$, the long $r\left(182^{\mathrm{b}} / 5\right)$, the latin $r\left(182^{\mathrm{b}} / 1\right)$ and the 2-shaped $r$ used in the neighbourhood of $o\left(182^{\mathrm{b}} / 1\right)$. Occasionally this 2-shaped $r$ has a tag descending below the line $\left(182^{b} / 13\right.$ and bottom line).

$i$ has usually a fine slanting hairstroke $\left(182^{\mathrm{b}} / 3\right)$.

$y$ is dotted and has an upward stroke $\left(182^{b} / 4\right)$. It is thus well distinguished from $P$ which is like the OE wynn (182b/2). 
The yogh (3) is used initially for the front spirant and medially where it has often no phonic value (spirizt, whizs). The respective territories of 3 and $g$ are not consistently distinguished. $g$ is generally used for (d3) and for the back stop, but note hygnesse, higze, reygnede.

$e$, especially at the end of a line, has a variant which slides on its back, lengthening its final loop till it is almost closed (183a line 5 from bottom).

Unlooped (uncial) $d$ is predominant; less frequently, looped $d$ is found which looks like the number $8\left(183^{\mathrm{a}} / 1\right)$.

The vertical of $t$ rises only slightly above the crossbar which makes the $t$ occasionally liable to confusion with $c$. Occasionally the upward loop of $t$ reaches the crossbar, e.g. in hit $\left(182^{\mathrm{h}} / 20\right)$.

\section{PUNCTUATION MARKS}

The punctuation is to some extent meaningful as it is semi-rhetorical and indicates how the treatise was intended to be read. There are three devices which call for some comment: the paragraph mark $(\mathbb{0})$, the inverted semicolon (:) and the point (.). The paragraph mark is used at the beginning of a new dialogue and to introduce either of the interlocutors. The point and the inverted semicolon are devices to guide the reader's intonation and are to be regarded as a guide to the proper movement of the treatise rather than as a grammatical punctuation. Originally a liturgical notation to mark modulations in the pitch of the voice, this type of punctuation made its contact with the English vernacular through the homily, already in the late Old English period $^{\mathbf{1}}$ and was extensively used in devotional literature.

The point is used as an indication to the reader to momentarily suspend the voice, thus often giving more weight to what follows. The point will sometimes be placed where modern punctuation uses a comma but not necessarily, as in these examples:

He hap openyd to pe. pe ocasion of vertu $3 / 8$.

Comytte pe cure of thi bodi. to pe souereyne leche $9 / 32$.

Among pi progenitoures. pou schalt haue alle pe hole preisinge 13/8.

1 Cf. P. Clemoes, Liturgical Influence in Late Old English and Early Middle English Manuscripts, Occasional Papers 1. Department of Anglo-Saxon (Cambridge, 1952) p. 16. 


\section{A. THE MANUSCRIPT}

The inverted semicolon or punctus elevatus denotes that the reader should slightly raise the pitch of his voice, the rising inflection indicating that the sense-unit is not complete, although it may appear so. For example:

De same god pat wrouzte pis maistries in Joseph: kan zeue pe sich a grace in pi lordes sizt: pat... pou schalt no lengere kepe pe cloistre of bondache 25/30.

Who so hath non of hem: is not only pore: but a verrey wrecche $31 / 36$.

It is also often used to mark parallelism of sentence members:

As pou art pore of money! be pore of spiryzt 35/25.

Whanne cornes tymen not: wepith pe frangeleyn. 29/3.

Sometimes absence of punctuation obscures the sense as in:

Mightiboned men pat be dulwitted in pe naturel ordere of men kepen pe lowest degre $7 / 13$.

where a point after dulwitted might have helped.

\section{E. EDITORIAL PRACTICE}

Abbreviations are expanded throughout and marked in italics. The paragraph mark and the ampersand (printed \&) have been retained. I have introduced capitals, question marks and paragraph divisions where modern practice requires them, but I have preserved the significant punctuation of the text in accordance with what is said in the preceding section. Corrections made by the original scribe are silently adopted but footnotes give the MS reading. Letters or words supplied without the authority of the MS are printed within round brackets and the MS readings recorded in footnotes. The few letters or words in the MS that require emendation have been omitted in the text but are duly recorded in footnotes. A double diagonal bar is placed in the printed text at the end of each MS folio and the number of the new folio appears in the margin. Initial $f f$ is reproduced $F$, wt is reproduced with, $i$ and $j$ are treated as in the MS, but have been capitalized in proper names and, in the case of $j$, when it is used for the pronoun. Thus the words for 'jewel' and 'evil' are spelled alike juel.

The following marks of abbreviation deserve notice: 9 above the line stands for -us in copious, glorous, but for -es (-is) when used for 
the plural of nouns; - us for the latter forms only once occurs in full. $\sigma$ above the line stands for $u, u r$ in likerous, doctour, nature, also in pedur, but $-u r$ never occurs in full ${ }^{1}$ for usual $-e r$. In the case of $p$, though this is often transcribed par, I have preferred to transcribe per for the sake of convenience and consistency, but there may be a phonological significance. See p. 58. The stroke over a letter regularly indicates omission of a letter (mostly a nasal) but it is often meaningless, especially after final $g$. Similarly the crossed $l l$ is sometimes used for $l l e(s)$, but sometimes need not be expanded at all. The habit of the scribe of inserting space in words like a zens, a ferd, with drawe has been reproduced.

As regards the Latin text of Petrarch, this is taken from the edition of Petrarch's Latin Works published at Venice, 1501, fol. 93r-97r (according to the numbering in ink in the B.M. copy). In order to present a readable text, abbreviations are silently expanded; the spelling of $u$ and $v$ has been regularized according to modern usage. I have corrected occasional obvious misprints, but recorded them in footnotes, marked $V e n$.

The passage from Boethius is taken from the edition by $\mathrm{H}$. F. Stewart and E. K. Rand in the Loeb Classical Library, pp. 178-180. The $u$ when used for the consonant is transcribed $v$.

\footnotetext{
1 -ur occasionally occurs in full in other parts of the MS, e.g. fol. $128^{\mathrm{a}}$.
} 


\section{B. SOURCES OF THE TEXT}

I. PETRARCH'S 'DE REMEDIIS UTRIUSQUE FORTUNAE'

The dialogue is a translation or rather a cursory paraphrase, with additions and omissions, of the first ten dialogues of the De Remediis Utriusque Fortunae of Petrarch. The rubrics presented are the following:

\section{Dialogue}

$\begin{array}{lll}\text { I De Deformitate Corporis } & \text { VI De Obscena Origine } \\ \text { II } & \text { De Imbecillitate } & \text { VII De Servitute } \\ \text { III De Adversa Valitudine } & \text { VIII De Paupertate } \\ \text { IV De Ignobili Patria } & \text { IX De Damno Passo } \\ \text { V De Originis Obscuritate } & \text { X De Tenui Victu }\end{array}$

The division into chapters in the Latin text does not correspond exactly to that of the English text. The first two dialogues have been compressed into one (without heading), which thus deals with the deformity and weakness of the body. The chapter of pouerte in the English text comprises dialogues VIII and IX of the Latin text. This latter fact derives authority from certain MSS and printed editions where De Damno Passo was not entered as a separate dialogue but was one with the preceding and entitled De Paupertate et Dampno. (Thus e.g. MS Harley 2570, MS Lansdowene 781 and similarly in the first edition of the De Remediis, Basle 1474). The English text, then, presents the following chapter headings:
1. (No heading)
5. of birthe in leccherie
2. of siknes
6. of bondache
3. of vnnoble cuntre
7. of pouerte
4. of pore birthe
8. of feble fare 


\section{a. Nature of Petrarch's Work}

The 'Remedies Against Varying Fortune'-according to one of his latest biographers 'the least amiable of Petrarch's works'1 - is divided into two parts. In the first book, the Remedies against Prosperous Fortune, it is demonstrated that everything that is generally regarded as valuable and conducive to happiness is in reality worthless and miserable, whereas in the second book, the Remedies Against Adverse Fortune, it is explained that what is generally regarded as affliction and misfortune should from the Christian philosopher's point of view be regarded as a help to secure salvation.

The work is dedicated to the consolation and edification of Azzo di Correggio, tyrant of Parma, a figure with an abominable historical record but whose colourful life must have attracted Petrarch, who obviously saw more in him than a common adventurer. He kept a life-long interest in him and on Azzo's death he addressed letters of consolation to his widow and children. Azzo was well qualified to appreciate the subjects offered to his contemplation as he had ample experience of the wayward nature of Fortune, having suffered bad health, exile, favour and loss of friends, bereavements and the sudden fluctuations of Fortune causing his deposition and banishment.

The work, which was started in 1358, was not yet finished when Azzo died in 1362 and Petrarch continued working on it till 1366, including in it, as it would seem, many of his own pet aversions and prejudices.

To each book he prefixed a long introduction setting forth the plan of the work. In the epistolary introduction to the first book Petrarch surveys the general misery of man's life. Man is oppressed from all sides and subject to the most various vicissitudes so that he is tossed hither and thither like a tennis-ball. Nature has provided all other living creatures with a wonderful kind of remedy, namely a certain ignorance of themselves, but man is not only afflicted by the troubles of the present but equally by his past and future cares so that he has continually to fight as it were a three-headed Cerberus. He concludes that it would almost have been better for us to have lacked Reason altogether since we are apt to turn this heavenly power against ourselves. Any man who seriously considers his own life should admit,

1 Morris Bishop, Petrarch and his World, p. 329. 


\section{B. SOURCES OF THE TEXT}

Petrarch observes, that its beginning is blindness, its progress toil, the end sorrow and the whole course error'.1

The purpose of the book is to guide man's mind in the effort to conquer the influence of Fortune. The only remedy is to resort to philosophy, namely to the writings of excellent moralists. Taking as a starting-point the De Remedins Fortuitorum of Seneca (to which he refers as a well-known work), Petrarch observes that Aristotle and Seneca have written that it is more difficult to counter Adversity than Prosperity, but Petrarch with due diffidence ventures to put forward his own view that prosperous Fortune is more difficult to bear than adverse Fortune.

It is for this reason that he is offering his Remedies against prosperous Fortune. He has seen many who were equal to the blows of Adversity but of those who were able to bear riches, honours, power, he has never yet seen any..$^{2}$ Finally he explains the device of the

1 Nor did Petrarch in some of his other works definitely commit himself on the side of confidence in human powers to cope with the difficulties of life in this world Cf De Vita Solitaria (translated by Jacob Zeitlin, Urbana, 1924, p. 101). 'For man is not only a base and unclean animal but furthermore . pernicious, unstable, faithless, inconstant, fierce and bloody, unless by the rare grace of God he puts off his bestiality and puts on humanity, in short, he learns to make himself a man out of a common creature'

Cf also the following passage from Suum Secretum, where through the mouth of Augustine, he depicts the muserable state of man: 'Behold him naked and unformed, born in wailings and tears, comforted with a few drops of milk, trembling and crawling, needing the hand of another, fed and clothed from the beast of the field, his body feeble, his spirit restless, subject to all kinds of sickness, the prey of passions innumerable, devord of all reason, joyful today, to morrow sorrowful, in both full of agitation, incapable of mastering himself, unable to restrain his appetite, at once greedy and timid, disgusted with what he has, longing after what he has lost, discontented alıke with the past. present and future, full of pride in his misery, and aware of his frailty, baser than the vilest worms, his life is short, his days uncertain, his fate inevitable since Death in a thousand forms is waiting for him at last'

(translated by W H Draper as Petrarch's Secret or the Soul's Confluct wuth Passion, London, 1911, p 70-1)

2 This observation was not so revolutionary It is actually a common 'topos of the exordium', to begin a work by stating one is going to write 'things unattempted yet in Prose or Rhyme' (cf Curtus, p $85 \mathrm{ff}$ ) The same thought is found in Boethius, De Consolatione, Bk II, Prose VIII. 'Etenim plus homınibus reor adversam quam prosperam prodesse fortunam' The Prick of Conscrence quotes St. Gregory to the same effect. 'Si omnis fortuna timenda est, 
dialogue form he employs. It illustrates how the four passions of the mind, Hope, Joy, Fear and Sorrow, brought forth at simultaneous twin births by the sisters Prosperity and Adversity, assail the mind of man. It is owing to the power of reason which governs the chief castle, that man's mind is saved from their attacks.

Then in 122 dialogues follows an astonishing catalogue of the most various things generally regarded as subjects for congratulation. Long life, beauty, strength, and health are condemned as worthless. Good memory, eloquence, esteem, wisdom, and religion attain their only merit when put into the service of ethics. True freedom is in the grave. The fine arts, aesthetic pleasures, love of woman, books, the fame of one's country, victory, peace are unmasked by Petrarch with a truly Saturnine keenness. Any sort of luxury is held up as something to be despised. People who enjoy the possession of peacocks, pigeons, bees, monkeys or even elephants and camels are presented with some drawback to gall their enjoyment. The theatre is degenerate and immoral. The visual arts can never equal the beauty made by God in nature. Family life is a complete debâcle, etc.

Book II arrives at the same conclusions but approaches them by the opposite method by showing that all the misfortunes which adversity bestows, far from being sources of anxiety, should really be valued as blessings in disguise or rather as welcome exercises for death. In the preface to the second book Petrarch states that of all the things he ever read or heard nothing took more firmly root in his mind than Heraclitus' dictum that all things originate in discord (omnia secundum litem fieri). He then illustrates with a wealth of examples-which is a 'tour de force' in itself-how in all nature strife, discordance and contrariety are rampant. Destruction and strife manifest themselves in plants and beasts and equally in the life of man. But it is not only external strife, therc is also internal contention; man is divided against himself and everyone witnesses continual warfare with himself in the secret chamber of his mind, so that he is never able to direct his whole strength to one course, but is drawn now this way now the other. Having thus made clear what he thinks are the real affections causing man's unhappiness, Petrarch apologizes for the use of the word

magis tamen prospera quam adversa'. (ll.1311.f.). It is quoted as a common maxim in the Romance of the Rose, (English version, ed. F. N. Robinson, 11.5409 ff.). 


\section{B. SOURCES OF THE TEXT}

Fortune in the title and in the work itself. It should be clear to anyone, he says, that he ascribes no authenticity to Fortune (as St. Jerome says, there is neither Fortune nor Fate) but he merely uses the term as it is normal usage and for the benefit of the general reader. ${ }^{1}$

More than in the first book the reader is struck by the quizzical nature of Petrarch's arguments. It is very well to unmask smug prejudices, as he does in he first book, but he now takes upon himself to explain away human misery and it is clear that in the 132 dialogues of the second book he will have difficulty in doing this consistently.

At times Petrarch's reasoning borders on paradox and he indulges in frequent absurdities, at any rate in the eyes of a modern reader.

It is difficult to say whether Petrarch was being consciously funny when Ratio replies to Dolor's complaint that he has lost his wife: 'In the sense in which one loses the fever or the itch, sometimes loss is a sort of gain'. The consolation offered the blind is that one should be content with one's memory of the sun; if however one has never seen it, the desire of a thing unknown should grieve one the less. An occupant complaining of his cramped abode is 'consoled' with: 'If your house is small, think of your grave'.

For a further discussion of this aspect of the De Remediis I refer the reader to p. [46], where I deal with the 'Consolatio'.

\section{b. The De Remediis A Humanistic Influence? Its Reception in England and on the Continent in the 14th and 15th Centuries}

Petrarch is mostly hailed as the first humanist. It would therefore be tempting to deduce that the English adapter of Petrarch regarded his effort as a tribute to Humanism in England. But it is in fact a work like the De Remediis which serves as a reminder of the many ties with which Petrarch was still bound to the Middle Ages. He has the adventurousness of the modern when he resolves on making the ascent of Mont Ventoux, but when he reaches the top, he starts reading his

1 Petrarch expresses himself to the same effect in Rerum Senilium, VIII, 3 and in Epistulae Familiaves (a letter to his friend, Pierre de Poitiers, in 1362). Marcel Françon in an article entitled 'Petrarch, Disciple of Heraclitus', Speculum, XI, (April 1936), pp. 265-271, asserts (with spccial reference to De Remediis) that under the influence of Heraclitus Petrarch transformed the trite conception of Fortune into 'a profound view of the world'. See also K. Heitmann, Fortuna and Virtus, which concentrates on the De Remediis. 
copy of St. Augustine's Confessions and in typically medieval fashion reflects on the vanity of worldly desires. ${ }^{1}$

It has been stressed ${ }^{2}$ that caution is needed in assessing the value of Petrarch's works as humanistic influences. Everything depends on the way these influences were assimilated. The Italian writers could be read for a long time without any awareness of the change in standards for which they stood. "Some of Petrarch's and Boccaccio's Latin treatises are typically medieval productions; besides, by the end of the fourteenth century both these authors had acquired an authoritative status analogous to that enjoyed by such medieval writers as, for instance, John of Salisbury or Walter Burley... Jean de Montreuil considered Petrarch a 'devotissimus, catholicus ac celeberrimus philosophus moralis'."3

In MS Arundel 334 maxims extracted from the De Remediis occur grouped together with maxims from St. Bernard and Boethius, where the company in which he finds himself is equally significant of Petrarch's reputation as a moralistic writer. Jean Daudin, who made a French translation c. 1378, recommends the work as a storehouse of moral doctrine (cf. p. [23], note 1).

This falls in with Petrarch's reception in England as witnessed in Chaucer. It is significant that of all Petrarch's works Chaucer should pick out the story of Griselda as fit for adaptation and inclusion in the Canterbury Tales. Nowadays not many seem capable of a sympathetic understanding of the story, our expectation of psychological profundity, dramatic intensity and life-like characterisation standing in the way. ${ }^{4}$ But the medieval mind made much of it. Petrarch singled it out of all the Decamerone for especial praise and he thought it worthy of putting into Latin. ${ }^{5}$

There is however no point in asserting that Petrarch's De Remediis

$1 \mathrm{Cf}$ W Dulthey, Weltanschauung und A nalyse des Menschen sert Renaissance und Reformation, Gesammelte Schriften, Leipzig und Berlın, 1914, II Band, p 20

a Cf Roberto We1ss, Humanism in England during the Fifteenth Century, 2nd ed, Oxford, 1957, p 22, and J Huizinga, The Waning of the Middle Ages, (Pelican Books) pp 324-25.

Weiss, op cat. p 22 and note.

4 Cf D W. Robertson, Jr, A Preface to Chaucer, Princeton, 1963, p. 276

- His interest in the story was a moralistic one as he points out in his letter to Boccaccio, (translated in J H. Robinson, Petrarch, New York and London, 1908, pp. 196-198), explaining that his object in re-writing the tale was not that his readers should imitate the example of this wife, but that they should 
is either 'medieval' or 'humanistic'. Petrarch has been bandied backwards and forwards as a missile in the combat between the 'renaissancists' and the 'medievalists' but such discussions necessarily bog down in the unsolved question how either period should be defined. It is interesting, however, to compare the attraction of the De Remediis with that of an equally influential work, the De Contemptu Mundi of Innocent III. Both works stress the renunciatory and ascetic tendencies so frequently thought typical of the medieval period. The $D e$ Contemptu Mundi sweeps away this world in favour of the next with a complete single-mindedness, but Petrarch's 'spernere mundum' is not quite so wholehearted.

From the nature of the De Remediis it is evident that he was not so much interested in writing a book of edification preaching otherworldliness, as in producing a handbook of the philosophy of life in the tradition of the stoic philosophers ${ }^{1}$ (cf. for instance Bk. II, dialogue xviii which is in the 'cynical' consolatio tradition). In his detailed observation of human conduct, and in his constant tendency to observe, reflect and generalize, Petrarch implies a recognition of the importance of worldly values; he wants to come to terms with life in 14th-century Italy. One cannot help noticing that many of his arguments in favour of renunciation are pseudo-arguments defending now his own preferences and dislikes, now what he feels he ought to despise or applaud as a good Christian teacher. ${ }^{2}$ Körting $^{3}$ stresses the dual nature of

be inspired to emulate her constancy. 'Anyone, it seems to me, amply deserves to be reckoned among the heroes of mankind who suffers without a murmur for God, what this poor peasant woman bove for her mortal husband'. Far from being human persons Griselda and the Marquis represent Patience or Constancy and a testing agent, and apart from the folktale basis many biblical overtones have been pointed out. (Cf. J. Speirs, Chaucer the Maker, p. 154 and E. Salter, Chaucer: The Knight's Tale and The Clevk's Tale, p. $42 \mathrm{ff}$., where it is referred to as a religious fable). Its appeal is also illustrated by Petrarch's story in the same letter that one of his friends burst into tears on reading the story because his capacity for goodness was touched.

1 Cf. W. Dilthey, op. cit. p. 21. 'Er wollte der originale Lebensphilosoph seiner Zeit sein'.

2 A. D. Deyermond, The Petrarchan Sources of La Celestina, London 1961, finds book II much weaker than book I and suggests Petrarch did not put his heart in the work, the direct response, emotional as well as intellectual which appears in book $I$, being gone (p. 51); but the greater number of medieval transcripts of Book II does not confirm this verdict for the Middle Ages.

a Petrarca's Leben und Werke, Leipzig, 1878, pp. $558 \mathrm{ff}$. 
Petrarch - the Christian ascetic and the humanist-and demonstrates in the De Remediis Petrarch's failure to blend satisfactorily the Stoic and the Christian solutions. In fact he calls the De Remediis a production imparting a completely unchristian pessimism and nihilism.

And indeed, Petrarch's most definite pronouncements (see p. [17]) would place him definitely among the dour Stoic type of philosopher. Dilthey (op.cit. p. 22f.) has a similar view. He stresses Petrarch's insistence on 'ratio' and 'virtus' in the tradition of Seneca but not without a lingering look at the doctrines of Augustine. He imputes Petrarch's pessimism to the conflict between his courageous determination to trust in Reason, and the half-hearted attempts to rekindle a decaying trust in the old securities which expected to find 'tranquillitas animi' in surrender to divine assistance.

One of the difficulties is the discrepancy between the professed theme of the work and Petrarch's private convictions which are frequently out of harmony. The plan and the conception of the work compel him to deny the values of the goods he chooses to discuss and conversely to praise their corresponding opposites, but there are many instances in which the arguments of one dialogue weaken or contradict those of another. Petrarch's arguments are double-edged and it is evident that Petrarch often had to rationalize what he did not support himself, for instance his negative attitude towards art, books, fame. Similarly his eulogy on the beauties of nature, of which he shows the most sensuous awareness in his description of the juices of plants, of flowers, colours, tastes, sounds, views of hills, shady woods, leisure of the countryside, etc., contradicts the renunciatory line of the argument, which is to denounce the value of art. ${ }^{1}$

The manipulations with which he denies values to the 'goods' of life and ascribes virtue to the 'evils' of life sometimes look like the sleight of hand of a conjuror. There is no doubt that many of the arguments are arguments to silence the opponent in the tradition of the stoic philosophers and the medieval schools, an exercise of which Petrarch acquits himself with obvious enjoyment. This gives the work a sphinx-like character and may qualify Körting's view that it sets forth a cynical denial of any values whatsoever. It should be clear, at any rate, that Petrarch's asceticism is of a different order than the otherworldliness preached, for instance, by Innocent III-an impres-

1 For Petrarch's view on poverty, which in his later years did not agree with that expressed in the De Remediis cf. p. [62]. 
sion only strengthened by the triumphant display of his intoxication with the Classics.

To the fourteenth century the De Remediis must have seemed a treasurehouse of consolation and edification, in 'sentence' only equalled by Seneca and Cicero. ${ }^{1}$ It kept away from systematic theology, dogma, doctrinal niceties, original sin, the sacraments and other theological specialities. Petrarch cites the Bible and the Fathers of the Church, but also the Latin Classics and it seems that Petrarch's greatest interest in the work was to show off his profane reading, often adducing a wealth of citations to illustrate a point which to convince did not need a single one. The additional attraction of the gloss of modernity must have been mainly the unrivalled knowledge of classical anecdote ${ }^{2}$ and also his authoritative cynicism which must have appeared extremely unorthodox. Adrianus Carthusianus in a preface to an abridgement he made of the work remarks that if anything in the work should displease or offend the reader it is not himself who is to blame but Petrarch. ${ }^{3}$

Petrarch himself valued his philosophical and moralistic writings far above his vernacular writings, expecting that his fame with posterity would be that of a moral philosopher. There is evidence that many of his contemporaries held the same opinion. ${ }^{4}$

1 In the preface to his translation (c. 1378) of the De Remediis Jean Daudin specially recommends it as a work habondant en tout fruit de doctrine morale... He cites at length the authorities incorporated in Petrarch's work for additional praise. Cf. L. Deslisle, 'Anciennes Traductions Françaises du Traité de Pétrarque sur les remèdes de l'une et l'autre fortune', Notices et Extraits des Manuscrits de la Bibliotheque Nationale, Paris, 1891, pp. 273-304.

y Körting, op. cit., p. 464, suggests that Petrarch must have been collecting these scraps of information from his wide reading with the industry of a bee. But much, too, is of course derived from florilegia, esp. Valerius Maximus.

- 'Preterea si quid in hiis (libris) inventum fuerit, quod lectorem offendat, si tamen aliquis attingere dignetur, vel quod ducat in errorem, quod honestatem non sapiat, vitam non instruat, virtutem non excitet, vel quod non edificet ad salutem, id noli esse meum protestor humiliter, revocans ac poscens correctionem'. (Preface to the printed ed., Cologne, 1470).

- Of the Latin works it was the De Remediis which enjoyed the greatest popularity, being the earliest work of Petrarch to be printed, (Basle, 1474) and the work which for centuries required the most new editions. But time has not confirmed this verdict. Though it was printed 20 times in the period 14701650 , in the last 300 years there seems to have been no need of a new edition, the latest edition dating as far back as the 17 th century. There is no critical edition. Today the work is mostly cited as an illustration of the medieval side 
The De Remedns enjoyed at once an enormous vogue. Before it was finished, the German Emperor Charles IV invited Petrarch to bring the work and read out passages to him Its populanty continued for centuries after it was written Numerous manuscripts copied it, selected maxims found their way into devotional manuscripts, translations appeared in all the principal European languages, ${ }^{1}$ various adaptations were made ${ }^{2}$ and its influence is evident in a number of other works ${ }^{3}$

As the dialogue of Aduersite and Resoun is not a literal translation, it would be unprofitable to search for the Latin text which the adapter used. Most of the manuscripts of the De Remedus in England are from the fifteenth century or later One 14th-century manuscript is known:

of Petrarch (cf $\mathrm{p}$ [19] and note) Zettln (The Life of Solvtude by F Petrarch, Urbana, Illino1s, 1924) remarks 'Of the De Remedus Utriusque Fortunae one may remark without a sigh that it had its day and ceased to be' (p 15)

1 Czech 1501, French 1523 (by Nicole Oresme or, more probably, Jean Daudin) and 1660, German 1532 (bk I by Peter Stahel, bk II by Georg Burckard Spalatınus, with a preface in verse by S Brant), 1539 and 1551 (by Stephan Vigiluus), 1596, 1604, 1620, 1637 A translation by Niclas von Wyle of dialogues 25 (de infamia) and 18 (de uxore amissa) of bk II, entıtled Trōstung $\imath n$ Widerwartıgkett is published among his other translations in the Bibliothek des Litt Ver Stuttgart, Italian 1549, 1589, 1863, 1867, Spanish 1510, 1513, 1516, 1518 , 1523, 1533, Dutch 1606 There is one English translation by Thomas Twyne Physicke against Fortune (1579) One other book purports to be a translation

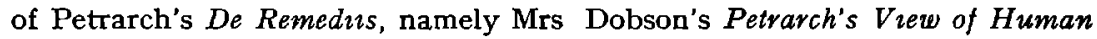
Life, 1791 and 1797, but this bears hardly any resemblance to the original

2 About 1410 Adrianus Carthusianus, a monk of the Carthusian convent of Geertruidenberg, Holland, made an adaptation comprising about one-third of the length of the original The arrangement in chapters is abandoned and the names of the disputants have changed into 'turo vanitatis' and 'cultor virtutis' This adaptation served Dirc van Herxen, rector of the Brotherhouse of Zwolle from 1410-1457, as a model to write some Remedia sive consolationes contra quedam adversa spiritualibus accidenina, a dialogue between Vecors and Consultus It formed part of his Devota Exercicia, an 'anthology' of edifying treatises According to his own testimony, he had also recourse to Petrarch's treatise and he supplemented the text with subjects adapted to the contemplative interests of the brothers under his guidance See below p [30] Johannes Pinicianus madc an adaptation in Latin distichs which was often incorporated into translations and Latın editions, as if they were by Petrarch Albrecht von Eyb (1420-1475) gives a highly condensed summary of the second book in Latin

- e g Fernando de Roja's La Celestina and Johannes von Saaz's Der Ackermann von Boehmen 
MS CCCC 40, which once belonged to John Blodwell, Dean of St. Asaph's c. 1429-33. (See note by M. R. James in the catalogue of the MSS preserved in Corpus Christi College Cambridge). Though beautifully executed, the text is inferior, abounding as it does with wrong sentence divisions, omissions, faulty spellings of classical proper names, etc., and it could hardly be the copy which served the adapter, as in various instances he shows the better readings.

The following is a brief survey of further manuscript evidence of the early reception of Petrarch's De Remediis in England. Master John Newton, treasurer of York Cathedral from 1393, left a copy of the De Remediis together with many other books to the Cathedral Chapter in his will of 1414 (Testamenta Eboracensia, ed. J. Raine, Surtees Society, 1836). In 1440 Robert Alne, 'Parson' of the Choir at York and officer in the ecclesiastical court there, in his will of this date, besides bequeathing several books to the Cathedral Church and other places, made a special grant to the University Library Cambridge of works of Thomas Aquinas, Aristotle, Boethius, Richard Rolle, Thomas of Hoveden and also Petrarch's De Remediis, which Mr. John Otryngham, Master of Michaelhouse in Cambridge was to retain during his life. ${ }^{1}$ Some other fifteenth-century manuscripts in English libraries containing the De Remediis or adaptations of it are:

British Museum, MS. Harley 2570

MS. Harley 1883

MS. Harley 3579

MS. Additional 10, 342 : complete

14, 808 : book II only

27, 336 : the adaptation of Adrianus Carthu-

MS. Arundel 334

Bodleian Library, MS. Rawlinson 455 All Souls College, Oxford, MS. 91

Peterhouse Library, MS. 271

Cambridge University Library, MS. L1.V.21 siensis

: 'flosculi' only, no dialogue form the adaptation of Adrianus Carthusiensis

complete

'Sententiae quaedam ex Petrarcha, Bernardo et Boethio desumptae'

extracts from both books

complete (owned and later donated by James Goldwell, bishop of Norwich)

: complete (in two French hands)

the adaptation of Adrianus Carthusiensis

1 Charles Sayle, Annals of Cambridge University Library 1278-1900, Cambridge, 1916, p. 19. 
MS. Ll.V.21 is in a Low-Countries script, but was acquired for Norwich Cathedral Priory by a monk who was sacrist in 1444.

The catalogue of the Augustinian Friars of York has an addition by a late 15 th-century hand listing the 32 'libri magistri Johannis Bukwode' (who does not occur in the lists of Oxford and Cambridge graduates by A. B. Emden). Among these MSS Petrarch's De Remediis is listed as no. $345 .{ }^{1}$

In an unidentified library catalogue in B.M. Harley 2268 of the mid-fifteenth century the compiler (apparently a Northern Englishman) has noted, f. $114^{b}$ 'Franciscus $P$. de remediis utriusque fortune in librario maioris ecclesie'. It is not certain, however, whether this Petrarch was in England in the first quarter of the fifteenth century, the period which concerns us. Other items in the catalogue show that much was collected abroad at the councils of Constance and Basle.

Humphrey, Duke of Gloucester owned three manuscripts of the De Remediis; one was presented by him to Oxford in 1439, another in 1444 and the third is now in the Bibliothèque Nationale, Paris. ${ }^{2}$

As is evident from the associations of some of the manuscripts listed above, the relatively wide circulation of the De Remediis in England and elsewhere does not necessarily point to humanism. In the first quarter of the fifteenth century - the period roughly to which our treatise is most probably to be assigned-we must not expect to find any literary circles in England engaged on humanistic pursuits such as existed in Italy. Humanistic interests developed slowly and were dependent on isolated patrons like Humphrey, Duke of Gloucester or on the leisured pursuits of prominent prelates like Bekynton and Adam de Moleyns. ${ }^{3}$ The real beginnings of English humanism date from the second half of the fifteenth century. The circulation of the Latin works of Petrarch in England from the second half of the fourteenth century does not imply that they exerted humane influence. They were appreciated for their lofty moral tone, the 'many fressh stories'4 and because of their style. The first impact of Italian humanism was,

1 M. R. James, The Catalogue of the Library of the Augustinian Friars at York in Fasciculus Ioanni Willis Clark dicatus, Cambridge, 1909, pp. 2-96. James notes that nine-tenths of the MSS were subsequently lost including the Petrarch.

a R. Weiss, 'An Unnoticed Manuscript of Humphrey, Duke of Gloucester', Bodleian Library Record, V (1955) 123-4.

s On Gloucester, Bekynton and Moleyns see Weiss, Humanism in England.

- Lydgate, see p. [28] and note 2 . 


\section{B. SOURCES OF THE TEXT}

significantly, not that of its spirit but that of the letter. The first thing that was grasped was the possibility to improve one's style, not the notion that one was confronted with a movement which would completely transform cultural values. Beaufort and Gloucester, the first fifteenth-century patrons of letters, were first of all desirous to enhance the prestige of their chanceries by employing as their secretaries Italian humanists like Poggio, Frulovisi and Decembrio. English men of letters too, when confronted with humane letters, seemed at first mainly anxious to devote their efforts to the cultivation of an elegant epistolary style which could compete with the correspondence which reached them from the Curia and the chanceries of Italian princes. To acquire a position at the chancery of a high official it was no small asset if one could boast the literary qualifications to conduct correspondence in accordance with the canons of classical Latin. The pursuit of belles lettres, in short, became a key to preferment. ${ }^{1}$

In the fifteenth century several English students attended Italian universities to continue their studies after taking their degrees at Oxford or Cambridge. But this did not necessarily mean that they fell at once under the spell of humanism. Even William Grey, who attended the lectures of Guarino da Verona in Ferrara-from 1445 onwards-, though he proved receptive to humanistic studies, kept theology as his main interest. Many others returned to England with their scholastic outlook unchanged. ${ }^{2}$

Before Poggio came to England in 1418 it is quite impossible to find any traces of humanism in England. ${ }^{3}$ To be sure, Englishmen visited Italy and doubtless came into contact with Italian humanists. But the real nature of the cultural innovations seems to have escaped them. Chaucer's diplomatic missions to Italy were not without effect on his literary development, but did not promote humanistic studies.4 Richard de Bury is known to have met Petrarch as early as 1330 when he was sent as envoy to the pope at Avignon. Petrarch described him

1 Weiss, Humanism in England, p. 75.

2 Weiss, p. 84.

3 Weiss, pp. 7, $11 \mathrm{f}$. On the term 'humanism' and the innovation humanistic studies represented as compared with medieval studies of the Classics see Weiss, introduction, pp. 1-5 and the various studies of P. O. Kristeller.

- The Canticus Troili in book I of Troilus and Criseyde is a fairly close rendering of Petrarch's Sonnet 88, 'S' amor non è', and one is of course familiar with Chaucer's adaptation of the Griseldis story in The Clerk's Tale. 
as vir ardentis ingenii, nec litterarum inscius ${ }^{1}$ and their common love of books must have provided them with many points of contact. Bury, however, could not follow Petrarch in all his interests. He remained unquestionably a schoolman, who held that knowledge was pre-eminently a weapon for the defence of the faith. Incidentally, it must be through visitors like him-or Italian officials in Englandthat the humanistic works found their way across the Channel. Bury died, however, in 1345, twenty-one years before Petrarch finished his De Remediis, which excludes him as the channel through which the work first reached England.

Other fourteenth-century scholars like Walter Burley or, later in the century, Thomas Walsingham, the chronicler of St Albans, though interested in classical literature, were still fettered by their medieval attitudes. Their Latin writings can hardly be credited with more than superficial humanistic influences. An English Augustinian friar, known as Thomasius de Anglia or Thomas de Clifton, was teaching in Florence in 1395. According to Weiss, English Miscellany, 9 (1958), p. 19, his interests were the new nominalist dialectics rather than humanism. Towards the end of the 14th century Adam Easton, bishop of Norwich, had brought manuscripts from Italy.

In the fifteenth century Lydgate shows familiarity with Petrarch's De Remediis in the Prologue to his Fall of Princes ${ }^{2}$ but nothing leads us to assume that Lydgate's knowledge of Petrarch was anything else but superficial or that his appreciation of the Classics was 'humanistic'. $^{3}$ It is suggested that humanistic influence was evident in the circle of John Seguarde-or Seward-(fl. 1414), centered in London, who practised the art of letters 'in not quite the old way'. ${ }^{4}$ Poggio's influence activated the humanistic interests of at any rate two Englishmen who were employed at the household of Henry Beaufort simultaneously with Poggio. They were Nicholas Bildestone and Richard Petworth. Bildestone's anxiety to read Petrarch and his

1 Epistulae Familiares, III, 1, quoted in CHEL, I, p. 216.

2 Lines 257-68, ed. H. Bergen, E.E.T.S. E.S., 122, pt II, p. 476.

3 F. Brie, 'Mittelalter und Antike bei Lydgate', Englische Studien, 64 (1929) $261 \mathrm{ff}$.

- V. H. Galbraith, 'John Seward and his Circle', Mediaeval and Renaissance Studies, I, London, 1943, p. 86; but see Weiss, Humanism, p. 7. 
attempts to acquire Petrarch's Latin works ${ }^{1}$ show his interest in the new literature.

Duke Humphrey's association with Italian humanists originated in his personal contacts with collectors and envoys sent to England by the Roman Curia. Piero del Monte, papal collector in England from 1435 to 1440, in particular, exerted great influence on the Duke and guided his interests in books and personalities. It was to a large extent through Humphrey's repeated donations of parts of his library to the University of Oxford that humanistic studies could advance there. Besides the three manuscripts of the De Remediis referred to above, Duke Humphrey possessed some of Petrarch's other Latin works including the De Vita Solitaria and the Rerum Memorandarum.

As for Cambridge humanism, the only humanistic work registered in the Cambridge University Library Catalogue, compiled in $1473^{2}$ is the $D e$ Remediis, ${ }^{3}$ the other authors being classical writers well-known during the Middle Ages. The St. Catharine Hall Catalogue drawn up in 1475 includes four modern Italian entries, these being two copies of Petrarch's De Remediis, Bruni's Ethics and Decembrio's Republic.

John Whethamstede, abbot of St. Albans from 1420 to 1465 , acquired a taste for humanism - but kept an abominable, turgid Latin style. He is known to have visited Italy in 1423 where he met humanists and probably inspected the very important Visconti Library at Pavia, which contained Petrarch's collection of manuscripts. ${ }^{4}$ Though appreciated highly for his classical scholarship by his contemporaries he remained fundamentally unaffected by modern influence. Of Petrarch he knew the De Viris Illustribus.

Richard Bole, secretary to Grey, presented among other books Petrarch's Secretum to Balliol College Oxford, which was copied in 1450.

Another Latin work of Petrarch which is found in a considerable number of manuscripts is the Historia Griseldis. In MS. Cotton Vespasian E. XII and in MS. Royal 8.13.VI it is found among a number of medieval moral treatises.

It is not necessary to extend this account beyond the first half of the fifteenth century. The general picture afforded by the accomplishment

1 In Rome during the year 1424, Weiss, p. 19.

2 Printed in Henry Bradshaw, Collected Papers, Cambridge, 1889, pp. 16-54.

a Probably the copy left by Robert Alne, cf. p. [25] above.

Weiss, p. 32 and note 8. 
of individuals and the type of Petrarch manuscripts available in England is consistent in showing a preference for his Latin moralistic works, among which the De Remediis is conspicuous. Moreover, the medieval company in which the De Remediis finds itself in most of the early manuscripts and the well-known medieval authorities with whom he was associated bear witness to the fact that in the period that concerns us Petrarch was received as a moralistic writer. It was quite well possible for medieval readers to appreciate his De Remediis without even knowing of the existence of his Canzoni and Trionfi, on which his fame with posterity rests.

A comparison with Petrarch's early reception on the continent presents a similar picture. In the Netherlands, for instance, Petrarch's reputation was at first that of a moralistic writer, who deserved a place beside the Fathers of the Church. Petrarch texts appear among devotional manuscripts in monastic libraries, in particular the moralistic works De Vita Solitaria, De Otio Religiosorum, De Contemptu Mundi, Historia Griseldis and the pseudo-Petrarchan Septem Psalmi Poenitentiales.

Presumably the oldest mention of Petrarch in The Netherlands is a reference to the De Remediis in a treatise entitled Sompnium Doctrinale (c. 1400) of Arnoldus Roterodamus (van Geilhoven), a monk interested in humanism. ${ }^{\mathrm{I}}$

Among the Brethren of the Common Life Petrarch's ascetic works found an easy acceptance. It is not difficult to see why. His works breathed the same spirit of renunciation and the same moralistic preoccupation which they valued in the patristic treatises. Petrarch's ideal of creating a harmony between scholarship and faith must have roused the sympathy of the more educated adherents of the Devotio Moderna.2 Among them Willem Vornken, rector of the Windesheim Chapter in the first half of the fifteenth century counted the De Vita Solitaria among his favourite literature. Dirc van Herxen (1381-1457), rector of the Brotherhouse of Zwolle, ${ }^{3}$ made use of Petrarch's $D e$ Remediis-or Adrian the Carthusian's version, see p. [24], n. 2-in his Devota Exercicia (1492) in an adaptation for the inmates of the Zwolle

1 See Catharina Ypes, Petrarca in de Nederlandse Letterkunde, Amsterdam, 1934, pp. $5 \mathrm{ff}$.

Ypes, P. 7.

s On Dirc van Herxen see P. H. J. Knierim, Dirc van Herxen (1381-1457), Rector van het Zwolsche Fraterhuis, Amsterdam, 1926. 


\section{B. SOURCES OF THE TEXT}

community. Beside the more Petrarchan subjects such as slander and tax-levies, van Herxen introduces such subjects as the distractions while praying, and impatience with regard to laxness and disobedience of those entrusted to the care of the brothers. Familiarity with Petrarch's De Vita Solitaria appears from van Herxen's Speculum Iuvenum.

Dionysius Carthusianus ( $\uparrow 1471$ ) cites in his works from Petrarch's De Vita Solitaria. The De Remediis is cited in Specula omnis status humanae vitae in two passages pleading for the study of letters, which should provide man with moral guidance (cf. De Remediis II, dial. 145: 'de scriptorum fama'). He further cites from II, dial. 7 in his discussion of obedience.

In this connection it is interesting to note the analogous reception of the Griseldis story in The Netherlands. The Griseldis story became known here through the Latin version of Petrarch rather than through Boccaccio's version. It is extant in a number of 15th-century translations, which are all included in collections of edifying literature. The spread of the story was to a large extent dependent on the moral interpretation given to it. In a version edited by J. H. Gallée ${ }^{1}$ a long ending is tagged on, which provides the poem with a spiritual interpretation, as is expressly stated in the title. In a perfect allegorical interpretation - four and a half pages in print - the virtue of patience becomes the main content of the poem. The germ of this interpretation had been provided by Petrarch himself in the letter prefixed to his Latin version, in which he stated that the story typifies man's obedience before God. But the elaboration of it seems to have been the condition on which the work became acceptable reading for nuns and brothers.

A Dutch translation of the pseudo-Petrarchan Historia de Arono et Marina, entitled Teghen die strael der minnen ${ }^{2}$ is equally provided with a moral interpretation. In this case the subject-matter is hardly edifying, but the moral tag manages to turn a dangerous subject into a spiritual parable.

It would seem then, that in The Netherlands as in England, the introduction of Petrarch texts points to humanistic interests, but the

1 'Een Nedersaksische novelle van Griseldis. Griseldis histori mit eynre geestelike bedudenisse', Tijdschrift voor Nederlandsche Taal-en Letterkunde, 4 (1884) $1-44$.

2 ed. R. Pennink, Twee uit het latın van pseudo-Petrarca en Petrarca veraalde middelnederlandse novellen. Zwolse Drukken en Herdrukken. Zwolle, 1965. 
adaptations show that they were received under definite conditions with a firm desire to neutralise non-devotional elements. It is possible that travelled Englishmen and Dutchmen of humanistic tastes brought the Latin materials from Italy, which were then given this hybrid form in religious communities, to occupy the minds of brothers, monks and nuns at mealtimes.

\section{c. The Translation and its Relation to the Original}

We have seen that the nature of the reception of the De Remediis in England and the audience for which it was designed, explain the fact that the 'Father of Humanism' should find himself adapted for use in a devotional manual. The manner in which the translator dealt with the work points the same way. A 'consolatio' has been turned into a 'contemptus mundi'.

The translation is by no means a close one. For comparison I print the Latin text ${ }^{\mathbf{l}}$ facing the English text, with the corresponding passages in italics. Thus one can witness the translator skimming through his original, sometimes omitting entire passages and adding other matter, sometimes summarising a passage by a proverb or a maxim (see Style and Proverbs, p. 70ff.).

One of the features of Petrarch's work is the dignified tone and the authority with which he introduces his readers to the fantastic and heroic world of antiquity. Now Petrarch's 'tour de force' in illustrating the most out-of-the-way topics with quotations and analogues from the classics found no echo in the translator. Of all the classical analogues in Petrarch the adapter takes over only the ones which would be familiar to a medieval audience. Where such is not the case he either omits the entire passage or cites an analogous example from the bible or from saints' legends. For instance in the first dialogue, De Deformitate Corporis, Petrarch illustrates his point, that beauty often stands in the way of virtue, by citing the case of Helen of Troy: if nature had made Helen or Paris deformed, Troy would still stand. Further he quotes the case of the beautiful youth from Thusca (borrowed from Valerius Maximus) who, having discovered that his beauty was a

1 The De Remediis is not readily accessible. In default of a critical edition I have used the rather scarce Venice edition of 1501, which offers the best text. The Basle editions of 1554 and 1581 are more generally accessible, but are marred by misprints and general careless press-work. 
cause of bad reputation, voluntarily maimed his face. In the English version nothing of this is mentioned, but instead the biblical analogue of Thamar and Amnon is cited: hadde Thamar Dauid is dowter ben a fougl leyth damesele. behap Amoun here bropur. hadde here not oppressed, with further conventional matter on the foolishness of women's toilet and Augustine's authority for the future splendour of the body at the resurrection.

Even in war a tall and well-shaped body is not a necessary requirement, says Petrarch. The great general Marius did not muster tall but strong-chested soldiers. Our author has instead the biblical illustration of the prophet Samuel, who was advised to forgo the tall stature of Eliab and to elect the little David king of Israel. Similarly, the paragons of strength, Milo and Hercules, appear as Josue, Judas Machabe, Ector and Arthour, who belong to the 'Nine Worthies' familiar to the Middle Ages. The result is that the general effect of the first dialogue is very much like the discussion of the transitoriness of beauty in a work like The Book of Vices and Virtues. ${ }^{1}$

To illustrate the fame of those who are 'of vnnoble cuntre' the case of Ruth is presented, while Lucifer is a case of one unworthy of his noble origin. In dialogue four 'of pore birpe' a longish passage is interpolated contrasting dame Fortune with dame Grace in favour of the latter, who enables children of men to become heirs to the crown of heaven. When Petrarch illustrates how slaves may rise in the social scale through their personal abilities, he takes the case of Terence's rise to fame as a writer of comedies. The English author prefers a biblical analogue and takes Daniel's interpretation of King Nabuchodonosor's dream and the story of the captivity of Joseph and his later royal status. In the chapter on poverty he inserts a eulogy on Job's patience in poverty. Consequently, Dr. Doyle's impression of the dialogue-before he was yet aware of the ascription to Petrarch-that it was 'in a common medieval convention' still seems a fair enough verdict. ${ }^{2}$

It should be clear that the alterations introduced by the translator are not in any way due to ignorance or 'simplicity'. We have to do here with an intelligent work of an independent author who manipulated

1 ed. W. Nelson Francis, E.E.T.S. O.S. 217, pp. 79-80.

2 A. I. Doyle, 'A Prayer attributed to St. Thomas Aquinas', Dominican Studies, Vol. I (July 1948), p. 233. 
the Petrarchan original skilfully to attain his own ends. Admittedly, he can hardly have been familiar with all the events and personalities Petrarch presents, and he may have preferred to omit what he did not understand. On the other hand, the quality of the translation shows a sure treatment of the Latin treatise. What he left out clearly did not interest him sufficiently, or rather did not suit his purpose of adapting Petrarch to an audience of religious. If he was writing for nuns or monks, his treatment is not narrowly pietistic. He extols literary fame, nobility and freedom as valuable goods-though he insists that they shall be subject to the conditions of virtue. His style is easy and assured and he has some flashes of wit and verbal puns which are independent of Petrarch. He freely picks his way through the original, succinctly compressing the moral wisdom, and goes off on his own when he thinks fit. In these cases his language is rich in terse sayings and pithy expressions. The string of maxims beginning at $9 / 6$ are all his own. At a stage where it suits the argument, he interpolates a passage from Boethius' De Consolatione Philosophiae (see below p. [37]). More than once, when Petrarch is silent about a Christian authority for one of his dicta, the translator supplies it explicitly, which may indicate that he knew the source independently or was in a position to check it (see e.g. note to $23 / 35$ ).

$\mathrm{He}$ also quotes authorities not mentioned by Petrarch, as e.g. Aristotle's dictum that there are servants of two kinds, servants according to nature and servants according to the law, 21/5. He supplies the names of St. Peter, of St. Paul and of Pernylle, which Petrarch, for some reason, does not mention. The comparison of a poor man to a naked wrestler is not in Petrarch, but occurs in a bible commentary, cf. note to $27 / 25$. Similar cases occur more frequently, as can be seen in the Notes. It should be noted, that the Flores Doctorum of Thomas Palmeranus may have provided some of the quotations. See e.g. note to 19/5. Part of this florilegium of biblical and classical authorities is extant in the manuscript (item five), written in the same period. This is, however, no necessary indication that this copy was available to the author.

The dialogue form, which already has an unconvincing pretence of liveliness in Petrarch, did not inspire the translator to any new effort. The English version abandons many of the frequent interpellations of Adversity and gives full rein to Reason as the moral teacher.

A suggestion as to why the translator (or copyist) stopped after the 
eleventh dialogue is ventured above, p. [9]. There is no evidence that the adapter had recourse to a French version, though there was one by Jean Daudin, canon of the Sainte-Chapelle, translated round the year 1378. ${ }^{1}$

\section{SENECA'S 'DE REMEDIIS FORTUITORUM'}

Properly speaking this is not a direct source of the English text, but I include a few remarks because it is the source which inspired Petrarch's De Remediis.

In the Preface to book I Petrarch professes to have been inspired to write his work by a 'libellus' by the hand of Seneca dealing with adverse fortune. This is a reference to the De Remediis Fortuitorum of Seneca. He adds that he has no desire to emulate the achievement of Seneca - though this is obviously his aim-but he wishes to do for his friend Azzo what Seneca did for his friend Gallio, in other words to write a consolatio.

Seneca's work has the following lemmata:

1. De morte

2. De decollatione

3. De morte in peregrinatione

4. De morte in iuventute

5. De morte sine sepultura

6. De aegrotatione

7. De maliloquio malorum

8. De exilio

9. De dolore

10. De paupertate
11. De impotentia

12. De amissione pecuniae

13. De amissione oculorum

14. De amissione liberorum

15. De naufragio

16. De rapina latronum

17. De inimicis

18. De amissione amicorum

19. De amissione uxoris.

All these subjects are also found in Petrarch's work but in random order. Petrarch's work is of much larger scope and Seneca's work is in comparison not more than a skeleton frame. In Haase's edition of 1853 it comprises only 12 pages. ${ }^{2}$

Whether it is genuinely Senecan is a matter of dispute. Lipsius (1615) notes that a blind man must see that it cannot be by Seneca,

1 See L. Delisle, 'Anciennes Traductions Françaises du Traité de Pétrarque sur les Remèdes de l'une et l'autre Fortune', Notices et Extraits des Manuscrits de la Bibliothèque Nationale, Paris, 1891.

' L. Annaei Senecae Opera Quae Supersunt, Vol. III, Lipsiae, 1853, Pp. 446-457. 


\section{INTRODUCTION}

but Haase (1853) is definite in admitting it as authentic. There is no doubt at any rate that in the Middle Ages it was generally accepted and respected as a work of Seneca. ${ }^{1}$

In some catalogues of manuscripts Seneca's De Remediis Fortuitorum is occasionally confused with Petrarch's De Remediis Utriusque Fortunae. Thus MS. Additional 27,336 (Adr. Carthusiensis's version) has the entry: liber de remediis fortuntorum and MS. Harley 3346 has Liber de Utriusque Fortunae Remediis whereas it refers to Seneca's work.

Its influence seems to have run largely parallel with that of Petrarch's work. There are numerous medieval manuscripts; just as in the case of Petrarch's De Remediis, Seneca's De Remedirs was his first work to be printed (Cologne, 1470); its influence was still alive in 1547 when Robert Whyttynton published an English translation. ${ }^{2}$ A certain Val. Boltz produced a German translation in 1552. In Dutch there is a medieval (14th-century) adaptation called Dit syn Seneka Leren, a dialogue between a father and his son. ${ }^{3}$

The relation between Seneca's and Petrarch's De Remediis was strengthened by the fact that some 14th and 15th century MSS incorporated additions drawn from Petrarch in the text of Seneca's De Remediis Fortuntorum. Thus even Haase in his edition of 1853, probably under the impression of producing something new, added to the text a number of Additzones which occurred in one of the MSS he used, thus perpetuating the medieval confusion. ${ }^{4}$

As for the occasional presentation of the work in dialogue form (mostly between Sensus and Ratio) I refer the reader to the discussion of the Dialogue (p. [38]).

1 e g by Tertullian ( \pm 250 ) in his A pologetrcus, Guillaume de Conches ( \pm 1150 ) in his Moralıum Dogma, Jacobus Magnus ( \pm 1400 ) in his Sophologium. Vincent of Beauvais $( \pm 1240)$ in his Speculum Histonale, and Walter Burley ( \pm 1300 ), who inserts a large extract of it in his De Vita et Moribus Philosophorum

2 ed. R G Palmer, Seneca's De Remedins Fortuntorum and the Elizabethans, Chicago, 1953

a ed. W. H D. Surngar, Dit syn Seneka Leven, Le1den, 1895

- Already there Haase suggests that they are possibly not Senecan, but by an imitator 'ut videatur Petrarcha alıquis', a supposition he later elaborated in an article added to the Index Lectionum in Unvers Litter. Vratislaviensi per hremen a. 1859 habendarum But in the later editions of 1872 and 1892 no alteration was made in the text 


\section{BOETHIUS 'DE CONSOLATIONE PHILOSOPHIAE'}

In the dialogue of pouerte there is an interpolation from the $D e$ Consolatione, Bk II, Prose II, namely the well known passage where philosophy addresses Boethius in the style and manner of Fortune. This is obviously the standard reference to the fickle nature of Fortune. The same passage is also paraphrased by e.g. Thomas Usk, ${ }^{1}$ The Roman de la Rose, ${ }^{2}$ in Chaucer's poem Fortune and by Machaut. ${ }^{3}$

Petrarch's text, which itself leans heavily on Boethius, may have given the cue. Referring to Fortune he writes: 'Non tibi fecit iniuriam' where Boethius has: 'Quam tibi fecimus iniuriam?' at which point the English adapter chose to make his own adaptation of Boethius, curtailing the text in the same free manner as he did with Petrarch's. I print the Latin text in between Petrarch's for comparison. ${ }^{4}$

As for the occasional brief digressions not found in Petrarch or Boethius $^{5}$ there is no one single source and there is no great profit in trying to hunt their sources.

Wherever I have identified a source or found an analogue I have mentioned this in the Notes but it should be realized that an analogue or source does not imply direct borrowing. In an age of compilation and endless regard for 'authorities' quotations freely circulated and one has to be content to note the conventionality of the idea. As might be expected these additions strengthen the devotional nature of the treatise.

1 The Testament of Love, Bk. I, Ch. X, ed. W. W. Skeat, Chaucerian and Other Pieces, Oxford, 1897, pp. $43 \mathrm{ff}$.

2 In the discussion on friendship, Engl, version $11.5201 \mathrm{ff}$. and $4353 \mathrm{ff}$.

s Remede de Fortune, 11. 2613 ff., ed. Ernest Hoepffner, Oeuvres de Guillaume de Machaut, Anciens Textes Français, Tome II, Paris, 1911.

- The text used is that edited by H. F. Stewart in the Loeb Classical Library, London, 1962, pp. 178-180.

5 Dr. Doyle drew my attention to the permeating influence of Boethius in the English text. Apart from the instance quoted, it is clear that the English author had a knowledge of Boethius which is independent of Petrarch. 


\section{LITERARY GENRE AND THEME}

\section{A. THE DIALOGUE FORM}

The dialogue form in Petrarch's De Remediis is not elaborated to any credible proportion-and in Reason and Adversity even less so. Dolor's part is restricted to short plaintive utterances, often repeated in similar phrasings, which are refuted in detail by a pontificating Ratio, whose part dominates the whole. The dialogue form as a literary composition is a familiar device in the Middle Ages, but it was used only in a few conventional applications and with a very narrow conception of its powers. 'Dialogue' is as vague an indication of contents as 'Summa', 'Sermo' or 'Speculum'. The Platonic type of dialogue, typically conveying the illusion of creative conversation and inviting the reader to join in a quest for truth, is scarce; the verse debate (débat, estrif, altercatio, conflictus) is mostly a jeu d'esprit fostered by the dialectic of the schools; but the most frequent type is the didactic dialogue. Most medieval dialogues are a schoolmaster's device to facilitate instruction ${ }^{2}$ or a moralist's vehicle to impart edification.

In many cases what might equally have been a prose treatise or sermon appears in the form of a dialogue with no more functional reason than is expressed in Wyclif's dictum: 'Locutio ad personam multis plus complacet quam locutio generalis'. Similarly, Wyclif remarks at the beginning of the first chapter of his dialogue Speculum Ecclesiae Militantis that he makes use of dialogue because many persons take pleasure in 'loquela dialogi'. The disputations of the

1 Cf. R. Hirzel, Der Dialog, 2 vols., Leipzig, 1895, who sees the medieval and modern dialogue as a dead form in comparison with its great past.

- Bede recommends the dialogue especially for children (Migne, P.L. XC, 614) and note also Aelfric's Colloquy. 


\section{LITERARY GENRE AND THEME}

schools were part of the cleric's education and it is natural that this habit which provided so much scope for display of acumen and wit should prove a favourite literary vehicle.

Among the humanists the dialogue, next to the oration and the letter, was the favourite literary genre. Here, too, one often looks in vain for that spirit of improvisation which lends life to the Platonic dialogue. The medieval dialogues are too often expositions of a preconceived theme and the dialogue form is adopted only as a pleasing method. ${ }^{1}$ The type is aptly characterised by $\mathrm{C}$. H. Herford ${ }^{2}$ who calls it a variety of monologue, 'a literary hendiadys'. With their uneven distribution of speeches Petrarch's De Remediis and the English Reason and Adversity show a tendency to this type of expository treatise.

On the other hand, the dialogue form here cannot be viewed apart from the genre of the 'consolatio' of which it often formed a corollary. It is probable that Petrarch adopted the dialogue form in deference to this time-honoured genre which found its most celebrated representative in Boethius' De Consolatione Philosophiae. According to P. A. Auer $^{3}$ the device of dialogue, presenting the 'consolator' as actually addressing the afflicted, is not a mere accidental device, but is itself part of the consolation, essential to the genre as form belongs to subject-matter. Often, however, in the course of such 'consolationes' the dialogue form recedes into the background and the 'consolatio' assumes the form of a moral treatise. This function of the dialogue in the 'consolatio' is not the same as in the classical dialogue between individuals. Many 'consolationes'-Boethius' De Consolatione and Seneca's 'consolationes' might be mentioned to start with-have only partially arisen from the need to console others; rather they rise from the need to quiet one's own mind. This gives to these dialogues the character of interior monologues, a struggle of thought with thought.

1 This type had equally its representatives in the classical period, witness such works as Cicero's treatises De Oratore, De Senectute, De Amicitia. Many of Seneca's treatises pass under the name of dialogues without the slightest claim to that title. Aristotle relegated the dialogue to the region of the popularisations of philosophy, for really scholarly writing the treatise was the proper vehicle (Cf Hirzel, Der Dialog, I, p 373)

S Studies in the Literary Relations of England and Germany in the Sixteenth Century, Cambridge, 1886, p 23

- Johannes von Dambach und die Trostbucher vom 11 bis zum 16. Jahrhundert, Munster 1 W , 1928 In Beitrage zur Geschichte der Phılosophie und Theologie des Mittelalters, XXVII, 1-2, pp $260 \mathrm{f}$ 
As E. Merrill shows, ${ }^{1}$ Boethius' dialogue De Consolatione inherits traits from the Platonic dialogue in its drawing out of thought by skilful questioning, but the limiting of the speakers to two and the fact that these speakers in some sense represent two conflicting tendencies in the writer's own mind, shows a trend towards the distinctly medieval debate. The disputation is transplanted to the inner man and becomes a conflict of opposing passions and personified abstractions. This device satisfied the desire to objectify one's inner motives and gratified the medieval tendency to give allegorical shape to psychological conflicts. Augustine's Soliloquies belongs to this type of dialogue. In Petrarch's Suum Secretum or the conflict of the Soul with Passion, two sides of Petrarch's character are opposed; the one, his everyday self, represented by Fransiscus and the other, his conscience, the critic, by Augustinus. The dialogue is an introspective exploration of his inner motives. Petrarch's De Remediis might have belonged here, if the work had been true to Petrarch's pretensions in the Prologue to Book I. Actually, the dialogue here is a purely formal device, used without exploiting its possibilities. This had its influence on the work as a whole. Petrarch has no consideration for unity of content or for a coherent structure. By having Dolor and the other figures utter ever new complaints, he is free to pass easily from one topic to another and to include any subject which comes to his mind: the frogs that pester him, the itch, bad smells, anything.

More directly, the dialogue form may have been suggested to Petrarch by the form which Seneca's De Remediis Fortuitorum assumes in some 14th and 15th century MSS. ${ }^{2}$ Whether the original text of Seneca implied a distribution to two interlocutors is uncertain (it certainly is absent in some MSS), but the form of the text which offers alternately threats like: Morieris! Decollaberis! Exulabis! and lamentations like: Aegroto! Pecuniam perdidi! Amisi liberos! would lend itself to adaptation into dialogue. This is at any rate the case in the quotation from the work in Guillaume de Conches' Moralium Dogma, ${ }^{3}$ where the interlocutors are Timor and Securitas, or Homo and Securitas or Fiducia and Securitas. Walter of Burley in his De

1 The Dialogue in English Literature. Yale Studies in English XLII, New York, 1911, pp. $15 \mathrm{ff}$.

2 e.g. MS. Harley 2268.

S Guillaume de Conches, Moralium Dogma Philosophorum, ed. J. Holmberg. Uppsala, 1929. 


\section{LITERARY GENRE AND THEME}

Vita et Moribus Philosophorum ${ }^{1}$ makes a point of including part of the De Remediis Fortuitorum as a consolation in adversity to his readers. Here the disputants are Sensus and Ratio. In various manuscript versions of Seneca's work ${ }^{2}$ the disputants are Gallio and Seneca, Nero and Seneca, or 'Sensus conquerens et Ratio confortans', demonstrating the triumph of reason over emotion in the Stoic tradition. In the 14thcentury Dutch adaptation in verse the dialogue is between a father and a son. ${ }^{3}$

In another branch of literature, the theological and devotional works in Latin of the medieval divines, similar disputants are found, as there are Augustine's Soliloquies between Ratio and Augustine, Ambrose's Dialogus Animae Conquerentis et Rationis Consolantis, Adam Scotus of Dryburgh's Soliloquium de Instructione Animae between Ratio and Anima and Isidore of Seville's Synonyma de Lamentatione Animae Peccatricis where the disputants are Homo and Ratio. Here, just as in Seneca's work, Homo complains of injustice, exile, poverty, humiliation, etc., and Ratio teaches how to bear this with equanimity.

The prime example of a dialogue between Fortune and Man is Boethius' De Consolatione Philosophiae which has influenced nearly all writers remotely dealing with the subject. I need only mention Machaut's Remède de Fortune $( \pm 1342)$ primarily based on Jean de Meung and Boethius, ${ }^{5}$ L'estrif de Fortune et de Vertu by Martin le Franc (after 1447); De Consolatione Rationis of Petrus Compostellanus (mid 12th century), the Controversia Hominis et Fortunae (13th century) and the Elegia de Diversitate Fortunae et Philosophiae Consolatione by Henricus of Settimello ( \pm 1193 ). Examples can be multiplied $^{8}$ but it may suffice to note the universality of the works, which, taking their cue from Boethius, explore the workings of Fortune in dialogue form. The De Remediis owes indeed quite as much to Boethius as to Seneca's De Remediis Fortuitorum.

1 Walter Burley, De Vita et Moribus Philosophorum, ed. H. Knust, 2 vols. Stuttgart, 1886.

2 e.g. in MS. Harley 2268 and MS. Harley 3436.

s ed. W. H. D. Suringar, op. cit.

4 Instructions for those who have newly adopted the religious life but are still troubled by worldly temptations. Ed. J. P. Migne, P.L., T. CXCVIII, 843-872.

s The editor, Hoepffner, notes that Petrarch evidently did not know this work. Op. cit., p. XVIII, note.

- See H. R. Patch, The Tradition of Boethius, New York, 1935, Ch. IV, Imitations and Influence. 


\section{B. THE INTERLOCUTORS}

\section{The Four Affections}

Petrarch's original conception of the dialogue form seems to have been quite definite, - the struggle of the Emotions with Reason-and is expressed in the Prologue to Book I:

'Sic autem ad legendum venies quasi quatuor ille famosiores consanguinee passiones anımı. Spes seu cupıdıtas \& gaudıum metus \&. dolor quas due sorores equis partibus prospentas $\&$ adversitas pepere hinc illinc humano anımo insultent Que vero arcı presidet ratı: his omnibus una respondeat clypeoque et galea suisque artıbus \&o propria vi. sed celestı magis auxilı circum frementıa hostıum tela discutat'

and further in the Prologue to the second Book:

'Quenam tandem illa passionum quatuor tempestas ac rabies' Sperare seu cupere \& gaudeve, metuere \&. doleve que rerum inter scopulos procul a portu miserum alternıs flatıbus anımum exagıtant

The four affections referred to by Petrarch as 'famosiores' are the 'unreasoning passions' of the Stoics. Ultimately derived from Plato's Phaedo, the idea is found e.g. in Cicero, Horace, St. Jerome, St. Augustine and Boethius. Virgil's verse hinc metuunt, cupiuntque, dolent gaudentque was especially influential. Petrarch knew it, as is evident from his copy of Virgil where he glossed this passage with a reference to Augustine's discussion of it in the De Civitate Dei, Bk. XIV.1 In Guillaume de Conches's Moralium Dogma we find the doctrine of these four passions elaborated into an all-round psychological analysis of the mind with further subdivisions into the various mixtures possible:

'Ad hoc notandum est, quod quatuor sunt affectus seu passiones in homine, de quibus Boethius

Gaudia pelle

Pelle timorem

Spemque fugato

Nec dolor adsit (De Consol Liber I, Metr VII)

Hi quatuor affectus debent taliter ordınar. primo dolor, secundo gaudium, tertio timor, quarto spes, nam dolor et gaudrum debent esse sıbı conjuncta, quia dolor sine gaudium nimium dejıcit, gaudıum sine dolore nimium extollit Similiter timor et spes debent esse conjuncta, quia tımor sine spe inducit desperationem, spes sine timorem facit praesumptionem Dolor ergo et gaudium sunt

1 See Klaus Heitmann, Fortuna und Virtus, Eıne Studie zu Petrarcas Lebenswershert, Cologne and Graz, 1958, p 127 


\section{LITERARY GENRE AND THEME}

duae molae, inter quas debemus semper vertı Aliae duae sunt tımor et spes; et nota, quod dolor et gaudium sunt de praesentı, tımor et spes de futuro, item dolor et timor tantum de malo, secundum cum quarto ambo de bono, item primo cum secundo, quia ambo de praesentı, tertium cum quarto, quia de futuro Istı quatuor affectus errant, nisı quatuor virtutibus dirigantur. Fortıtudo ergo necessaria est contra dolorem, temperantia contra gaudium, prudentia contra timorem, justitia autem contra spem' 1

This describes the plan of the De Remedtis even better than Petrarch himself does. The four affects are misguided dispositions of the mind and can be regarded as illnesses (aegritudines) according to the Stoic view and as sins in the Christian view. Petrarch associates them with the seven deadly sins in Suum Secretum as was commonly done from early Christian times onwards. Only Reason is able to subject these affects to his rule with the assistance of the four cardinal virtues Temperance, Fortitude, Justice and Prudence. Spes is probably best translated by 'cupidity', gaudium as 'elation', dolor as 'dejection', and metus as 'anxiety'. The ruthlessness and consistency with which Petrarch denies all values to the 'goods' and attributes value to the 'evils' of life is characteristic of the Stoic conception of reason and the passions, and is Stoic rather than Christian in emphasis.

\section{The Figure of Ratio}

Petrarch evidently concentrated on Ratio's part at the cost of Dolor and the other disputants. Only once, in dialogue 114 of the second book, is Dolor allotted more than his usual one-line utterance. He complains that Ratio's arguments are plausible in the schools and celebrated in books, but that they are not able to give assistance on the rack, or to climb into the beds of the sick; they are more easily spoken and written than practised. To many modern readers this sole outburst must seem to come rather late in the day and one might feel disappointed that even this complaint of Dolor is not given a fair chance. Reason is indeed a most longwinded bluestocking, whose advice is too rationalistic for modern taste. But this view is different from the prevailing medieval conception of Reason and the implications it had to the medieval mind. In modern everyday usage the term has lost much of its wider

1 Quoted from Thor Sundby (ed), Della Vita e delle Opere di Brunetto Latın, Appendice Terza: Gualterı ab Insulıs liber quı dicitur Moralıum Dogma, Furenze, 1884 
meaning and often bears the connotation of merely the dry logical faculty and a regrettable absence of emotion: 'the heart' is often favourably contrasted with 'the head'. But in medieval references the emphasis is the other way round. Reason is the faculty through which man can rule his life and it is favourably contrasted with his emotions, through which he is at the mercy of events. Seneca, the great authority for the Middle Ages, says that Reason should rule the passions. Reason in his conception follows nature. It is only when man strays away from nature that he is compelled to be a slave to all casual chances. ${ }^{1}$ Cicero declares that 'virtue can best be summed up as right reason'. ${ }^{2}$ Seneca says similarly that virtue is nothing else but right reason. ${ }^{3}$ St. Augustine writes: 'Reason rules the passions and other vicious parts of the soul.'4 Alanus de Insulis contrasts reason with lust: 'The one dishonours man, the other mightily transfigures him into a God'. ${ }^{5}$ The fact is that Reason is nearly always linked with virtue. ${ }^{6}$

Man's life was regarded as a perpetual struggle of the lower elements against the higher, or of reason against the senses; it was a conflict in which the victory of reason resulted in virtue, defeat in sin. By many writers this conflict was depicted allegorically as one between 'Sensus and Ratio' or 'Reason and Sensuality'. Virtue could only be achieved by coercion and repression of the passions by Reason. Both Christian asceticism and Stoicism had this conception, but interpreted it differently. Thus Reason could act as the stoic agent that could affect an internal adjustment between two extremes of feeling-a result achieved only by a few very wise men - and, in a more Christian spirit, it could be viewed as one of the gifts of partial divinity in man, 'a gleam of God's face'. But in the Christian view Reason could only succeed in its conquest of virtue through the mediation of divine grace.

Reason, when defined as the power to distinguish between good and evil, tended to be equated with conscience. Reason could similarly be equated with the soul. Reason, indeed, was an overwrought term.

1 Epistulae Morales, xcviii.14.

2 Tusculan Disputations, IV, xv.34.

a Epistulae Morales, lxvi.33.

- The City of God, Bk. XIX, Ch. 21 (A Select Library of the Nicene and PostNicene Fathers, Vol. II, Buffalo, 1887).

5 Planctus Naturae, Prose III.

- Cf. C. S. Lewis, The Discarded Image, Cambridge, 1964, p. 158: 'nearly all moralists before the eighteenth century regarded Reason as the organ of morality'. 


\section{LITERARY GENRE AND THEME}

According to R. Hoopes, 'Right Reason' has been 'invoked variously in the history of western thought as a rational concept, a moral principle, and a human faculty. It denotes, in other words, a mode of knowing, a way of doing, and a condition of being'. ${ }^{1}$ The strict distinction of scholastic philosophy between Intellectus and Ratio is not a feature of medieval popular or poetic usage. To Thomas Aquinas Ratio refers to the plodding, step-by-step progression by which man deduces one proposition from another, whereas Intellectus is the single uncompounded grasp of an intelligible truth. Thus the contemplation of God was typically a function of the Intellect. In less strict usage Ratio generally meant Rational Soul and as such implied both Intellectus and Ratio. It was the superior faculty by which man was distinguished from the beasts, who have only the Vegetable Soul and the Sensitive Soul. Ratio in this wider sense stood for the moral consciousness and for the contemplation of the truth; it presided with equal validity over the realms of intellect and morality.

Petrarch voices a sceptical feeling towards Reason in the Prologue to book I of the De Remediis when he says that so many men turn this power against themselves. But there is no doubt that the plan of the work accepts Ratio as the organ of morality, 'the force of our heavenly nature'. In the same Prologue Petrarch says he is going to demonstrate that Reason overcomes the passions suis artibus et propria vi; sed celesti magis auxilio. He states here, consequently, the orthodox view that reason relies on divine grace and thus stresses the Christian view as opposed to the Stoic view. It should be noted, however, that the Stoic element weighs heavier in the De Remediis than is here announced by Petrarch. He relies pre-eminently on the power of the intellectual approach and on his rhetorical aptitude. Only when the struggle of life becomes too strenuous, is Petrarch prepared to invoke the auxiliaries of God's grace. Besides, the normal assumption that Reason leads to virtue is subject to some qualification, as virtue in Petrarch is not without its worldly aspects. ${ }^{2}$

As regards the formal possibilities of the presentation of Reason at war with the four affects of the mind, one would think that Petrarch had found an admirable vehicle to present his conviction that the never-ending cycle of strife, witnessed everywhere in nature, is equally

1 Right Reason in the English Renaissance, Cambridge, Mass., 1962, p. 1.

2 On some of the humanists' interpretations of 'virtue' see pp. [59] and [65]. 
present in the mind of man. Thus one might have had an exploration into happiness, misery, fear, etc., in which the dialogue form would have been functional in presenting the various passions of the mind struggling for predominance. His ability to present his own inner questionings in a well-balanced dialogue is evident from his Secretum. But in the De Remediis Spes, Gaudium, Dolor and Timor, rather monotonously, merely serve as a device to introduce a subject for discussion. No retort is ever made to the capable arguments of Ratio. The Stoic conception of the nature of the misguided affects can, of course, never admit a sensible retort to the arguments of Ratio. Ratio is not a partner in the discussion, he is the sole authority. In the words of J. H. Whitfield, the lines of Spes and Gaudium, Dolor and Metus do not provide 'an interlocutor, but a sort of bell-press to start Reason off again'. ${ }^{1}$

The effect is the same in the English version. What is thus stressed is the contrast of the blind, unreasoning importunity of Aduersite, helpless against the slings of Fortune, and the capable, well-organised figure of Resoun who in the role of the preacher provides a wealth of moral maxims.

\section{THE 'CONSOLATIO'}

Petrarch states that his motive for imitating Seneca's De Remediis Fortuitorum was the desire to do for his friend Azzo what Seneca had done for his friend Gallio, that is, to provide him with advice how to seek redress from the blows of Fortune. In this he was impinging on a literary genre which had many analogues in classical and medieval literature, namely the genre of the 'Consolatio'.

The consolatio has an interesting philosophical ancestry and derives ultimately from the Greek 'diatribe', of which it gradually became the most popular representative. ${ }^{2}$ The 'diatribe' was a popular conference on a philosophical theme addressed to a non-specialized audience to assist them in the hardships of life. ${ }^{3}$ Without exploring the more abstruse subjects of philosophy its aim was to popularise a philosophical

1 Petrarch and the Renascence, Oxford, 1943, p. 55.

2 C. Favez, La Consolation Latine Chrétienne, Paris, 1937, p. 10.

- Cf. E. Albertini, La Composition dans les Ouvrages Philosophiques de Sénèque, Par1s, 1923, p. 304. 
doctrine and, above all, to propagate a moral. It was par excellence a product of the cynic-stoic school. The form it acquired may be regarded as a debased form of the Platonic dialogue. The dialogue which Plato used was too difficult to reach broader layers of the public; the downright dogmatic and didactic treatise was too blatant. The 'diatribe' provided a middle form to supply those interested in philosophy with the necessary teachings in a medium which was sufficiently attractive and suggested a modicum of improvisation and interplay of opinion. ${ }^{1}$ The type is characterised by various rhetorical devices which ensured a direct appeal: the use of a familiar and realistic vocabulary, pithy metaphorical language, quotations from favourite authors, proverbs and maxims, and in general a striving after rhetorical effects which would be as many pretexts for applause. ${ }^{2}$

In the field of practical morality the 'consolatio' became the chief representative of the 'diatribe' and, gradually moving out of the sphere of pure speculation, it naturally adopted many of the characteristics of the sermon and the didactic treatise.

The genre of the consolatio was first practised by Crantor $( \pm 300$ B.C.) in his treatise on Sorrow. In Rome it was practised by such famous authors as Seneca (Ad Helviam de Consolatione, ad Polybium de Consolatione, ad Marciam de Consolatione and De Remediis Fortuitorum), and Cicero in his Disputationes Tusculanae. And, naturally, Boethius' De Consolatione Philosophiae belongs here. The genre was, as Favez demonstrates, readily assimilated by Christian authors like Paulinus of Nola, Ambrose, Jerome and Cyprian. ${ }^{3}$ Later in the Middle Ages the De Duodecim Utilitatibus Tribulationis of Petrus Blesensis, ${ }^{4}$ Albertano da Brescia's Liber Consolationis et Consilii ${ }^{5}$ and the Consolatio

1 Cf. U. v. Wlamowitz-Moellendorff, Antıgonos von Karystos, Exkurs 3, Der Kynısche Predıger Teles, Berlın, 1881, p $292 \mathrm{ff}$

2 P Wendland, Philo und die Kynisch-Stovsche Dratvibe, Berlin, 1895, p. 3 f.

3 Favez, P $15 \mathrm{ff}$ Recently a case has been made out for taking the $\mathrm{OE} W$ anderer and the ME Pearl as Christian 'consolationes' Cf J E Cross, 'On the Genre of the Wanderer', Neophrlologus, XLV (Jan 1961) 63-75 and V. E. Watts, 'Pearl as a Consolatio', Medium Aevum, XXXII (1963) 34-36

- Also in two medieval English versions: The Twelve Profits of Tribulation, Yrksh.Wr., II 45 and 390

b ed Thor Sundby for the Chaucer Society, London, 1873. This is the indurect source of Chaucer's Tale of Melibeus, which, with its wealth of maxims, the dialogue form and the figure of dame Prudence, displays some characteristic features of the 'consolatio' 
Theologiae of Johannes of Dambach (Johannes de Tambaco) ${ }^{1}$ show the persistence of the genre, not in the last place through the steady influence of Boethius.

It was especially the Stoic philosophers who preferred to avail themselves of this type of composition. They regarded it as their mission to guide their fellowmen to conquer the hardships of life. It became even a sort of profession. The great houses in Rome had such 'directors of conscience', exercising the delicate functions that are now the domain of the confessor or the psychiatrist. They would offer such a 'consolatio' mostly to serve a specific case-a bereaved father, a husband pestered by a difficult wife, the loss of a friend, or of wealth. In this respect these compositions have the character of letters of condolence and encouragement. On the other hand they would have a more general application and in that respect they would resemble didactic treatises.

The subjects entered for discussion consist invariably of a limited number of recurrent themes, whose treatment acquired a stereotyped form. The same consolations are presented again and again, the most frequent being those concerning death, exile, old age, blindness, loss of possessions, bereavements, etc. ${ }^{2}$ The comfort offered is mostly of the following nature: When we mourn somebody's death we should remember that we might equally well have mourned at his birth: it was then he started to die. When a son has died young we may be comforted by the fact that the number of his virtues will equate what others have achieved in years. Against exile the comfort offered is that the whole world is our fatherland or that our true home is in heaven. If somebody has lost his eyesight he is presented with a catalogue of the evils that are now spared him. If somebody is oppressed by grief, he is told that if his sorrow is acute, it will be brief, if it is long, it will be bearable.

The genre has a pronounced rationalistic character. Worse, many of the arguments make the impression of sophistic exercises. C. Martha

1 Cf. above p. [39], note 3. Auer's work considers a wealth of 'consolationes' and affords a useful illustration of how widespread the genre was, especially in the later Middle Ages.

2 Cicero refers to this type of literary composition in Disputationes Tusculanae, III, 81 and Seneca in Epistulae Morales 94, while in Ep. 95 he professes the solution of these evils to be his proper mission, regarding the consolatio as a part of ethics. 


\section{LITERARY GENRE AND THEME}

notes that the consolations offered are frequently of a surprising feebleness or of a cruel puerility. ${ }^{1}$ To cite an example from Seneca who affords consolation to a man who has lost his eyesight: 'Habet et nox suas voluptates'. ${ }^{2}$ In Petrarch the argument adduced to console Dolor in his complaint that he has lost his money is pure sophistry: 'Ut non amisses si tua esset: sic si tua non erat emittere nequivisti'....' Often wordplay serves to silence the opponent: 'Dolor: Pecuniam perdidi. Ratio: Bene si te illa non perdidit'."

In Reason and Adversity there is the same type of argument. In answering Aduersite's complaint that he is 'oppressid with pouerte', Resoun concludes by saying: 'to pleyne pe pat pou berest heuye: wanne pou berist litil! is a wrong formed pleynt.' ${ }^{5}$ When Aduersite complains: 'Pe charche ob bondage weyith heuy vp on my nekke', Resoun answers: ... how mayt pou pleyne pe pat pou art heuy charched sipthen pou gost half void?'

It seems hard-hearted and hardly in good taste to present someone who is in the throes of suffering, with commonplaces and abstruse reasonings which add up to: 'Are you mad to be miserable?' These 'preceptes outrés, pointilleux, inhumains' seem to be an inevitable accessory of the consolatio ${ }^{6}$ and it may be worth while to examine this aspect somewhat more closely. It is exactly in this that the consolatio is true to its philosophical and rhetorical heritage. The rhetorical exercise of countering the objections of the opponent is evident. But to stress this element too much is to approach the 'consolatio' from the outside and to do injustice to the genre as a part of philosophy and ethics. Paradoxically it is not their lack of sympathy which induced the writers of consolations to indulge in what irritates us as an exaggerated degree of rationalism. Rather it is the poignant need for the perspicacity of reason in the chaos of emotions which stimulated them to sharpen their rhetoric and muster all their ingenuity. The conviction

1 C. Martha, 'Les Consolations dans l'Antiquité' in Etudes Morales sur l'Antiquite, Paris, 1883, pp. 135-189.

2 De Remediis Fortuitorum, XII, 1.

- De Remediis Utriusque Fortunae, Book I, Dialogue xiii.

4 ibid. Similarly Seneca: 'Pecuniam perdidi. Et ea quam multosl' D.R.F., XI, 3.

5 See text $27 / 26$.

- C. Martha, op. cit., p. 167. He cites a consolatory letter of Descartes to a friend who had suffered the loss of his hand in war and afterwards the loss of his brother, advising him to note the similarity of both experiences and not to be affected by the second loss any more than the first. 
dominating the 'consolatio' is a profound belief in the power of Reason, in the salutary effect of the frequently repeated maxim and the magic of the rhetorically pointed phrase.

The 'consolatio' presupposes as a prime exercise the 'praemeditatio futurorum malorum'. ${ }^{1}$ By constantly keeping before his eyes man's mortality the philosopher does not become a pessimist, nor 'accidentprone', but he is concentrating his strength to face disaster wellprepared and lessens the risk of losing his equanimity. He is convinced that without a good dose of rationalism one cannot dominate one's emotions and that the ideal of impassiveness is only achieved by an unconditional adherence to the precepts of Reason.

Concordant with this faith in Reason, and indeed a special aspect of it, is the faith in the power of the word. The word is able to evoke a possibility in a compelling way so that it may become almost magically present. This is the point where the sophists draw upon all their resources of rhetoric. It is as if no sooner than a remedy is formulated it becomes a magic word, whose salutary power we may cling to; as if the more it is repeated, the more it becomes true. This may sound magical, but it is primarily rationalistic in its assumption that there will be a direct correspondence between one's contemplation of the possible and one's experience of reality. The well-phrased consolation can transform our sorrow, divest it of its immediate poignancy and put our individual sorrow in the wider perspective of human misery. The consolatio does not deny the potency of grief. It does not explain away or belittle it. It only refuses to accept the sufferer's presentation of it. The consolatio administers an antidote ${ }^{2}$ and this naturally should activate different faculties from those causing our grief. What should not escape us under the grim aspect of the stoic attitude is the constant concern with happiness. It may appear harsh towards the selfpitying sufferer but it has understood the secret that grief has a purifying effect when viewed as a part of the human condition. Instead of despair the consolatio offers the rule of Reason. Even if the stoic consolatio should go so far as to deny the actuality of suffering, this should hardly be called insensitivity; it is rather the determined counter-movement

1 See Dr. Corn. Verhoeven, 'Filosofie van de Troost' in: Rondom de Leegte, Utrecht, 1966, p. 65.

2 C. Martha calls the consolatio a 'pharmacie morale' and it is thus regarded as a kind of psychotherapy. 


\section{LITERARY GENRE AND THEME}

against an all too vivid realisation of the disturbing power of the emotions and of the necessity to hold them in check.

Naturally, the demands made on Reason and the word are more exacting, the more the belief in their magic is fading. The occasional sophistries must be seen in this light. They become ridiculous once the force animating them is gone. But originally they were part of the attempt to exorcise the passions. The true stoic must have delighted in them, as the more sophistic they were, the more they marked his advance in subjecting his Emotions to his Reason.

If we are irritated by the commonplaces and cliche's we should take care not to underrate their social value. It is precisely the commonplaces, which, if rightly administered, hold most power to soothe and console. They constitute a common fund of wisdom and it is their truth, tested by generations, that offers an escape from individual misery. The most shocking truths do not seem readily amenable to original formulation and it is the old commonplace which can suddenly be filled with new meaning.

\section{THE GOODS OF NATURE, OF FORTUNE AND OF GRACE}

It is clear that in the 120 odd lemmata of each of the books of the $D e$ Remediis Petrarch has expanded his range of subjects considerably beyond the conventional topics the 'consolatio' afforded. It has been suggested that Petrarch like a bad-tempered old gentleman used the work as a storehouse for his own personal dislikes. ${ }^{1}$ Though this may be true it should be stressed that the subjects form quite a neat catalogue of the 'Goods of the Body, the Soul and of Fortune', which division was a familiar 'topos' from late antiquity onwards.

The division of the goods into those of the body, the soul and fortune already occurred in Aristotle's Ethics and featured frequently in the discussions about the definition of the summum bonum. The distinction is found also in Cicero's De Officiis, in Augustine's De Civitate Dei, in Boethius' De Consolatione and in Thomas Aquinas' Summa Contra Gentiles. But it seems to have been reserved for the Middle Ages to make a veritable science of the subject.

A particularly elaborate classification is found in the Moralium

1 Morris Bishop, Petrarch and his World, London, 1964, 'The De remediis is the work of an aging man indulging his insufferable petulance', p. 330. 
Dogma Philosophorum, the work of the epitomator Guillaume de Conches (1080-1150), professor of philosophy and grammar at Paris. ${ }^{1}$ $\mathrm{He}$ provides the following table with subdivisions:

\section{BONA CORPORIS}

dividuntur in:

Pulchritudinem. Nobilitatem. Velocitatem. Robur. Magnitudinem. Valetudinem.

BONA ANIMI

dividuntur in:

Scientias. Virtutes

$$
\begin{aligned}
& \text { COMMODA FORTUNAE } \\
& \text { dividuntur in: }
\end{aligned}
$$

Opulentiam. Praelationem. Gloriam

$$
\begin{gathered}
\text { Opulentia } \\
\text { dividitur in: }
\end{gathered}
$$

Aedificia. Agros. Clientelas. Peculium. Thesaurum. Ornatum.

This classification, sometimes in slightly different forms, provided a framework for discussions of the seven deadly sins in such works as the Somme des Vices et des Vertus of Frère Lorens (1279) and hence in the English Azenbite of Inreit and the Book of Vices and Virtues.

It is also found in Deschamps ${ }^{2}$ and in Chaucer's Parson's Tale, where the subject is treated in connection with the sin of pride. The goods are inspected one by one and warned against as as many sources of that sin.

In the devotional works mentioned above, the three kinds of divine gifts show a different order. The gifts of Grace are added but, in order to preserve the threefold classification, the goods of the body and the goods of the soul have been grouped together as 'goods of nature'. Thus Chaucer's Parson's Tale has the following classification:

1 J. Holmberg (ed.), Guillaume de Conches, Moralium Dogma Philosophorum, Uppsala, 1929. Formerly the work was attributed to Gualterus ab Insulis, e.g. by Thor Sundby in the 3rd appendix to his Della Vita e Delle Opere di Brunetto Latini, Firenze, 1884.

Oeuvres, S.A.T.F., III Pars, T. X, 450.

2 F. N. Robinson (ed.), The Works of Geoffrey Chaucer, Boston, 1957, p. 241. 


\section{THE GOODES OF NATURE}

1 goodes of body

heele, strengthe, delivernesse, beautee, gentrice, franchise.

2 goodes of the soule

good wit, sharp understondynge, subtil engyn, vertu natureel, good memorie.

II. THE GOODES OF FORTUNE

richesse, hyghe degrees of lordshipes, preisynges of the peple.

\section{THE GOODES OF GRACE}

science, power to suffre spiritueel travaille, benignitee, vertuous contemplacioun, withstondynge of temptacioun, and semblable thynges.

In this connection it may be noted that the familiarity of the discussions of the three goods in medieval devotional works may have facilitated-and determined the manner of - the adoption of Petrarch's work in the medieval English context.

E. THE HAPPY HUMANIST AND HIS PREOCCUPATION WITH MISERY: PETRARCH'S DE REMEDIIS AND THE CONTEMPTUS $M U N D I$ LITERATURE

It may seem surprising after reading Burckhardt's ${ }^{1}$ appraisal of the Renajssance 'emergence of the individual' and the 'discovery of the world' to find so many humanist writers concerned with an adverse view of the goods of this world and with a decided preference for a retired life 'procul negotiis'. The question imposes itself how so much antagonism to a lusty, worldly existence could possibly be present in the thought of the humanists, when the time in which they lived provided plentiful examples of boisterous, or calculated pursuit of wealth and pleasure.

The Italian humanists of the fourteenth, fifteenth and sixteenth centuries produced an extraordinarily large number of treatises on

1 Jacob Burckhardt, Die Kultur der Renaissance in Italien, 1860 (many editions). 
happiness, the summum bonum, human dignity, fortune and fame, but it is striking that most of these come down on the side of stoic renunciation rather than on contented enjoyment or a sense of achievement. The fact that in our present age peace is a frequently discussed subject does not prove that we live in an age of peace. The same sceptical view is applied to the abundant crop of discussions of happiness in the Renaissance period by C. E. Trinkaus. ${ }^{1}$ In his study of the Italian humanists' writings on happiness and the related subjects of nobility and human dignity he comes to the conclusion that 'the happy humanist' is a modern creation and that in reality their philosophy displays 'insecurity, resignation and despair'. These are forceful terms which, however, present a valuable modification of the common emphasis on the humanists as uninhibited and passionate personalities and on their inordinate appetite for enjoyment. ${ }^{2}$ A large number of the humanists stressed the inner antagonism of human nature; they preached contempt of the worldly goods and stressed the need to curb the demands of the senses. The distinctly negative view of man as exhibited in Innocent III's dour work De Contemptu Mundi found continuation among the humanists in Conversino da Ravenna's De Miseria Humanae Vitae. One wonders, consequently, in how far the spernere mundum theme as found in Petrarch's later works presents the same otherworldly asceticism as is found in the works of the medieval divines and whether it is necessary to assume any original humanist contributions in this discussion.

Critical interest in these treatises has not generally credited them with originality or much intrinsic interest. The various opinions agree

1 Adversity's Noblemen, New York, 1940. Some of the works which Trinkaus discusses are: Petrarch (1304-1374) Secretum de Contemptu Mundi; Giovanni Conversino da Ravenna (1343-1408) De Miseria Humanae Conditionis; Coluccio Salutati (1331-1406) De Saeculo et Religione; Francesco Zabarella (1366-1417) De Felicitate Libri Tres; Mafeo Vegio (1407-1458) De Felicitate et Miseria Dialogus; Leonardo Bruni (1369-1444) Isagogicon Moralis Disciplinae; Lorenzo Valla (1407-1458) De Voluptate ac De Vero Bono Libri Tres; Poggio Bracciolini (1380-1459) De Miseria Humanae Conditionis Libri Duo; Bartolommeo Fazio (1400?-1457) De Viri Felicitate; Buonaccorso da Montemagno (1391?-1429) De Nobilitate and Matteo Bosso (1427-1502) De Tolevandis Adversis Dialogus.

2 'Trinkaus' book represents the tendency to revise Burckhardt's neglect of the ascetic tendencies of the age, and to consider social forces as factors in the shaping of the humanists' attitudes. 
only in granting them a new interest in aesthetic form and an increased interest in ancient literature. The cultivation of a new lofty style purified from the barbarisms of their medieval predecessors was one major concern of the humanists. After all, the humanistic movement arose in the field of grammatical and rhetorical studies and the humanists were really the successors of the medieval rhetoricians. Their most characteristic contribution was the new perspective they brought to the study of the classics. Instead of looking-in the typically medieval style-for scattered scraps of wisdom, or anecdotes interpreted allegorically, they were able to appreciate the ancient spirit for its inspiration and beauty of form and cull from it the stimulus of moral grandeur.

The humanists also held the chair of moral philosophy. Their professed interest was to be the restorers of leaming and introduce the wisdom of the classics as a new vogue, couched in the pure Latin of Cicero. They made it their task to discourse in large terms on human values and man's position in this life, never forgetting beauty of form and elegance of expression. However, in many of them the dullness of the Middle Ages reappears in loftier terms. Their moral philosophy presents little more than exercises in verbose moralising and-in Kristeller's words - if we try to sum up their arguments and conclusions, leaving aside citations, examples, and commonplaces, literary ornaments and digressions, we are frequently left with empty hands'.1

Ascetic and otherworldly tendencies have been asserted as fundamental traits of Renaissance thought. ${ }^{2}$ It is especially these treatises on human happiness which support the tendency of some scholars to reject the notion of a clear-cut Renaissance spirit and to stress the powerful medieval affinities of the period. On comparing Petrarch's

1 P. O Kristeller, Renaıssance Thought, Harper Torchbooks, New York, 1960, pp. $17 f$

2 Thus D Bush, The Renarssance and Engltsh Humantsm, Toronto, 1939, p 68. The classical humanism of the Renaissance was fundamentally medieval and fundamentally Christian' Conversely, L Thorndike, Scuence and Thought in the Fifteenth Century, New York, 1929, refuses to see anything 'humanistic' in the moral treatises he examines except 'a slight classical coloring in nonessentials' (p 194).

For a histoncal perspective of the changing views of the Renaissance see W. K. Ferguson, The Renaissance in Histoncal Thought, Cambndge, Mass., 1948 
De Remediis with Roger de Caen's Carmen de Mundi Contemptu of the eleventh century we find many of the same traditional arguments, which have sometimes survived in very similar phrasings.

Thus power is denounced because it entails danger; the poor man is better off because in violent storms he remains unharmed. Riches are denounced because the rich man is perpetually worried by his desire for gain; the poor man on his miserable straw mattress enjoys unperturbed sleep. Precious stones are base ornaments; man, the image of God, has no need of them. One should adorn oneself with virtues to secure honour in the eyes of God. How transient the value of splendid dwellings is should be evident on consideration that one will be buried within the narrow confines of a coffin. The possession of large estates is an encumbrance rather than a source of happiness. One really needs very little to live. Instead of cultivating one's land one might more profitably cultivate one's soul. True nobility is not inherited, it is acquired through virtue. High position is denounced for two reasons: it is not what it seems; the burdens are greater than the profit; fame is short-lived and its possession is insecure. Secondly, the soul is perturbed in striving to retain it. It is better to be a servant than a master. Through his continuous worry the master is worse off than the servant who can regard him as his steward. The possession of health is an unstable good; how can one love what the pest and death can instantly wrench away? Honour, glory and riches are no safeguard against death. Strength is a despicable good; some animals are stronger than man. Youth will turn to decrepit old age. Beauty is transient, it is the enemy of chastity, an obstacle on the road to virtue. Woman is the ruin of man's liberty and rest. Her interest in cosmetics and her toilet arrangements are ridiculous, unnatural and disgusting. If one suffers for the death of one's children it is good to remember that they have died young, before the age of passion in which they might have indulged in sin.

The general line of thought regarding these goods can be summed up in the following argument which can be traced in Augustine's $D e$ Civitate Dei, Bk. XIX, in St. Thomas' Summa Contra Gentiles, Bk. III, pt. I, in Platina's De Vera Nobilitate and in the De Nobilitate of Buonaccorso da Montemagno.

Human happiness is not to be found in the goods of forlune, such as money, power, dwellings, and honours, since they are sought for the body or the soul, and bring cares, dangers, and enemies. Nor is it to 
be found in bodily goods, which are subject to the slightest injury and easily lost. It has to be found, by an internal adjustment, in the goods of the soul. But it is not found through the irrational part of the soul, which possesses the power of acuteness and enjoys pleasures, since many animals excel man in acuteness, and since pleasures are often mixed and followed by long and heavy sorrows. It is not found in the exercise of the natural powers of the rational part of the soul such as acumen, memory, boldness of will, because they can be employed for evil purposes. It has to consist, therefore, in the acquired powers or virtues. Of these especially efficacious are the speculative virtues culminating in the contemplation of God.

The debate on 'true nobility' which features so largely in these treatises, had been a common topos since classical times. It was treated in much the same way and with the same arguments by Seneca in his letters, by St. John Chrysostom in his Homilies on the Gospel of St. Matthew, IX, 7, and by the 12th and 13th-century troubadours who, in order to place themselves on the same social level as the great ladies of the courts with whom they were associating, defined nobility as the possession of virtue. ${ }^{1}$ The general view in these discussions is that true nobility is not inherited, hence the descent from noble ancestors is no guarantee for the heir, for noble parents have often had wicked children. Nobility depends on personal merit. ${ }^{2}$ Many persons of low birth have become great men, as is witnessed by the example of Cicero, Cato, Socrates and Euripides. On the other hand, the descendants of great families have often been wicked, disgraceful or obscure. Virtue and nobility come only by one's own exertions, since the soul, the seat of virtue, is not inherited and is superior to the body.

In these discussions of nobility the subject of poverty is regularly incorporated and it is demonstrated that poverty and nobility can exist side by side. Poverty - not destitution or beggary, but contentment with very little-is true wealth. Poverty is an easy guest and accords well with virtue and nobility since it removes the more serious obstacles.

Especially when the argument is summarised the sameness of these

1 See Curtius, European Literature and the Latin Middle Ages, trans. Trask, pp. 179 f., where further instances and sources are found.

- The adjective 'noble' nowadays more usually connotes ethical respectability than lofty birth. This spiritualised meaning has gradually grown out of these perennial debates. 
views is striking. The differences become evident when attention is paid to variations in emphasis and details of treatment.

The first difference lies in the totally different audience. Roger de Caen writes for a cloistered company of monks. His arguments extol the monastic life and are coloured by the tactical device not to allow any regret to rear its head for the world they have left. His reasonings prove more than once sophistic and he is not afraid to distort human values. ${ }^{1}$ Petrarch does not write for a group of religious specialists, he addresses his fellow-humanists who shared his interest in humane letters and often took an active share in the life of the city. Their focus had changed to a particular and individual preoccupation with their own place in the universe and the moral, philosophical and aesthetic consideration of it all. They explored, and found it worth exploring, the concrete uniqueness of their feelings, their opinions and their surroundings. ${ }^{2}$ Besides, it is unwise to regard these humanist treatises simply as phases in the history of thought in a political and social vacuum. Thus, in spite of what has been said about the conventionality of the themes discussed, it is to be noted that the theme of nobility and the debate of the vita contemplativa versus the vita activa had acquired a particular urgency in fourteenth-century Italy. It is not that the subject is approached differently or that the arguments change. It is rather that the social environment was peculiarly apt to foster heated debates on the nature of true nobility, man's status in society and the relative merits of his pursuits. In these discussions nobility was virtually treated as the summum bonum, as happiness; to prove one's title to it was the justification of the ultimate aim of one's existence.

In Florence, the matrix of early humanism, a new civic wealth had fostered a strong sense of achievement and power among the merchant class. Feudal class stratifications had become less important; social intercourse began to ignore distinctions of caste; birth and origin were of less importance than wealth. The civic society of Florentine merchants had long been conscious of the flagrant contrast between the old ideological notion of power - that of the medieval feudalism of Church and State-and the reality of power of the cities, and took a lively interest in defending their title to nobility. As von Martin, Baron

1 R. Bultot, La Doctrine du Mépris du Monde, Tome IV, 2, Louvain, 1964, p. 71 .

3 Kristeller, Renaissance Thought, p. 20. 
and Martines, ${ }^{1}$ among others, have maintained, the humanist circle was closely associated with the ruling class of wealthy citizens. ${ }^{2}$ They shared their ethical and political interests which they supported ideologically by creating a public opinion which accorded with the social situation. ${ }^{3}$ The manifold relations between the moneyed bourgeoisie and the new intelligentsia originated in their common civic origins and their mutual interests-for the former the new forms of social 'representation', for the latter material and social support.4 The humanists who represented the civic attitude, identified nobility with virtir, which they interpreted as probity and energy in action and, more particularly, as success in business pursuits. Thus the rich bourgeoisie found a recognition of their economic labours in this new nobility which at the same time they denied the dissipated and wasteful 'nobility'. It was a form of spiritual competition which ran parallel with and supported the economic and political competition. ${ }^{5}$ Poggio in his treatise De Nobilitate vents his anti-feudal resentment when he writes that a man is the further removed from true nobility the longer his ancestors have plied the trade of brigands.

Thus the idea of virtue presents a semantic problem here. Instead of stressing the need for reliance on the grace of God, which was and is the principal connotation of 'virtue', the humanists used the word in its original sense of 'manly vigour'6 and, in particular, it stressed the notion of 'public merit', and reliance on one's own prudence and cunning. It became the characteristic notion of a society in which fame and the achievement of a spectacular career had become for many a goal of life.

As for themselves, the humanist writers similarly claimed a share in

1 A. von Martin, Soziologie der Renaissance, Frankfurt am Main, 1949, p. 67; H. Baron, The Crisis of the Early Italian Renaissance, 2 vols., Princeton, 1955, passim; L. Martines, The Social World of the Florentine Renaissance, Princeton, 1963, pp. $267 \mathrm{ff}$.

- The common alternative view, that the humanists were rootless men of letters, mostly necessitous and forever looking for support and employment is very incomplete and results from a one-sided reading of Burckhardt and Voigt.

s von Martin, p. 67.

ibid., p. 73.

s ibid., p. 66.

- Cicero gives vir as the etymology of virtus in 2 Tuscul. xviii. Boethius says virtus is so called quod suis viribus nitens non superetur adversis, De Cons., IV, Prose vii. 
'nobility' by identifying nobility with virtus which here acquired the intellectualised meaning of the pursuit of their own special brand of literary studies. ${ }^{1}$ In their own view the practice of virtue was most perfectly exemplified in the life of the humanists, namely the ideal type of philosopher contributing to the common good.

This intellectualising of the idea of virtue is a heritage of stoic and generally of antique philosophy. When one proceeds from the assumption that virtue is determined by knowledge it is the next step to regard the pursuit of knowledge as the pre-eminent moral virtue. Hence the application to study was the best suitable way to live. Just as study contributed to one's own good, eloquence enabled others to share in one's knowledge. The cultivation of eloquence often came close to being considered virtue itself. We have seen the value attributed to eloquence by the consolatio. The humanists by equating their rhetorical and philosophical studies with the ideal life saw themselves in the high role of the restorers of learning, as the sages who instructed the public in the virtues of useful citizens. The vindication of eloquence-which had traditionally been associated with moral philosophy or 'civil philosophy' - was at the same time a justification of the social value of the studia humanitatis as opposed to the more sterile specializations of contemporary philosophers. Garin has shown how for Petrarch eloquence as literary discipline and philosophy as cultivation of the soul are closely related.2 Another humanist, Ermolao Barbaro, could say: duos agnosco dominos, Christum et litteras.

In the best humanists the educational and social value of their literary studies seemed to warrant their term studia humanitatis. On

1 Trinkaus finds the humanists' emphasis on equating nobility with their way of life an indication of a feeling of insecurity They had to convince others that nobility in its 'real' or 'true' sense coincided with their own life-and thus hoped to convince themselves A similar stress on the humanists' feeling of insecunty is found in E Fromm, The Fear of Freedom, Routledge Paperback, London, 1961. According to him the Renaissance individual was above all concerned with the problem of man's personal adjustment in a hostile world. While in the medieval framework of society man had his proper place assigned to him, the men of the Renaissance had lost the security the medieval social structure had offered 'The new freedom brought two things to them: an increased feeling of strength and at the same time an increased isolation, doubt, scepticism and - resulting from all these-anxiety ' ( $p$ 40)

2 E Garin, Der Italienische Humanısmus, Bern, 1947, p 11 


\section{LITERARY GENRE AND THEME}

the other hand, with lesser minds, there was the tendency, equally noticeable, to degrade litterae to nothing more than rhetoric, the cultivation of which degenerated into ephemeral beauties.

The subject of poverty was subject to many fluctuations of opinion among the Florentine humanists. They sometimes act as the mouthpiece of the Florentine merchant class who in reality took pride in their wealth as the true source of Florentine greatness; sometimes they stress poverty and renunciation as the sole justification of their existence : the wise man's independence of social position and material possessions. This rejection of worldly standards and the substitution of ascetic and otherworldly moral or religious standards has been variously accounted for. According to Trinkaus it indicates a doubtful attitude towards man's condition in this world and was 'clearly a desire and a hope to overcome or transcend the social and material insecurities and the accompanying emotional stress of this life'. ${ }^{1}$ But Trinkaus draws copiously from the works of highly placed or wealthy humanists, whose economic independence and social position can hardly be called insecure. ${ }^{2}$ On the other hand, the cultivation of the stoic and apostolic ideal of poverty - at any rate in theory - was a pose assumed by many. Petrarch, for one, had successfully published this image of himself. A humanist, poet, scholar, and restorer of a greater past should also exhibit in his personal character the superior virtues of the ancients, and should be free from envy, greed and search for preferment. After Petrarch this pose became a conventional element in the self-presentation of the humanists who in reality were often openly vain, profitseeking and greedy. It probably served to induce self-respect and to give a sense of ultimate purpose and moral value to the practice of humanism. It implied that a person such as a humanist, who subordinated his worldly desires to ascetic or otherworldly ends was a superior and more truly human person. Trinkaus calls this their intellectual snobbishness and suggests that in reality the renunciation

1 Trinkaus, p. 70.

- As Martines has shown, 'nearly all (Florentine) humanists belonged to the ranks of the ruling class' (p. 267); 'In part, in large part, the force of humanism in the Florentine community was the disguised force of the ruling class itself' (p. 270). Though in some cases their stress on poverty and asceticism may have been 'sour grapes' induced by their own necessitous living conditions and lack of support, this can hardly explain the insistence on poverty of a humanist like Salutati, who occupied the Florentine chancellery for a long time. 
of honours and of ambition displays despair of attaining them. ${ }^{1}$ In this respect they assumed a decidedly uncivic attitude; as the representatives of the intelligentsia they held themselves aloof from the settled citizens who naturally valued their wealth. ${ }^{2}$

Petrarch's position with regard to wealth is ambiguous. ${ }^{3}$ His early years were ruled by the ideal of Franciscan poverty and renunciation in which the classical praise of poverty and the Christian examples seemed to meet and be reconciled. It was in his semi-monastic flight from the world during his stay in Vaucluse that these views seemed vital and congenial. But the influence of his splendid career soon caused conflicts, voiced, for instance, in his Secretum. His coronation as a poet in the Capitol (1341), his vain endeavours to obtain a priorship in Central Italy and his acceptance of the protection of the Visconti tyrant mark his straying away from the renunciation of fame, worldly riches and social position. On the whole, Petrarch never entirely forswore positions of wealth; he gradually came to adhere to the golden mean', for which he could find authority in Cicero and Senecathe same authorities cited in favour of poverty by his contemporaries.

Petrarch's views underwent within the span of his life the evolution that would continue among the humanists for more than a century after him. Though in the De Remediis the aged Petrarch clung to the traditional stoic convictions, it is evident from confidential letters to his friends that he was really converted to his new ideas of the golden 'mediocritas', for which he could find admirable historical examples in his reading. At the end of his life he had come to the position that wealth and poverty made little difference and that everything depended on an internal solution.

Closely allied with the subject of wealth is the discussion of the relative merits of the vita activa and the vita contemplativa, which took on its own special flavour in Renaissance society. As H. Baron has

1 This is the very argument with which Augustinus-the interlocutor in Petrarch's Suum Secretum - deflates Franciscus' denial that he has entertained thoughts of ambition and honours. 'You mortals renounce many things, not because you despise them, but because you despair of attaining them'.

2 In their praise of poverty the humanists often indulged in a political romanticism by contrasting the simplicity and indifference to material needs in the early history of the Roman Empire with its later wealth and degeneracy, cf. De Remediis, dialogue ix (p. 32, $11.31 \mathrm{ff}$.).

- See H. Baron, 'Franciscan Poverty and Civic Wealth as Factors in the Rise of Humanistic Thought', Speculum, XIII, (Jan. 1938), 1-37. 
repeatedly emphasized, it was not until the beginning of the fifteenth century that the civic view came to full fruition in Florence when it heroically defended its freedom against the threat of tyranny. 'The heart of the change since the early Quattrocento is that a revolt has taken place against the ideas of the time when humanistic scholars had been content with a philosophy that compounded medieval ascetic ideals with stoic precepts of the aloofness of the true sage from society and public duties. From the end of the Trecento onwards, the ever-recurring leitmotifs in the humanistic philosophy of life were the superiority of the vita activa over 'selfish' withdrawal into scholarship and contemplation; the praise of the family as the foundation of a sound society; and the argument that the perfect life is not that of a 'sage', but that of the citizen who, in addition to his studies, consummates his humanitas by shouldering man's social duties, and by serving his fellow-citizens in public office.'1

In itself the debate on the superiority of the active life as compared with the contemplative life is not a criterion of 'modernity'. Petrarch was able to state the arguments for each effectively, as is evident from his De Viris Illustribus and Africa on the one hand and the De Vita Solitaria and DeOtio Religioso on the other. To him both could represent the good life. It is really one of those perennial debates in which the humanists, like thinkers in other periods, took different sides. Yet it is instructive to take note of Baron's illustrations of the particular function this debate assumed in the early Quattrocento.

As Baron has said, the humanists, in their study of the classics, at first tended to read only what they thought confirmed their renunciatory views. 'Of the complex world of antiquity they (the 14thcentury humanists) recognized only the features akin to the pessimism and renunciation of life which took possession of mankind in the period following the terrible epidemics in the middle of the fourteenth century. Seldom in the course of the Middle Ages has so much been written concerning the 'miseria' of human beings and human life as here at its end, and it was particularly the advocates of Petrarch's humanism who contributed to this literature.'2

The civic view is represented in the writings of Salutati, Poggio and Bruni. Instead of Seneca and the monastic tradition, Cicero is cited in support of the active life, not the aloof stoic sage of the Middle Ages,

1 H. Baron, Crisis, I, pp. $6 \mathrm{f}$.

2 Baron, 'Franciscan Poverty', p. 12. 
but the Cicero who combined political and literary activities in a perfect expression of the civic ideal. Similarly, instead of the old theory of the mind-body cleavage-which could disqualify all the claims of participation in active life simply by introducing the mind-contemplation-God progression-the Aristotelian notion was restored to honour that man by his very nature is a social and political being. Decembrio, as a representative of a later generation, criticised the rigidity of Petrarch's views in the De Remediis as untenable. Platina now turned to Aristotle's definition of nobility as the combination of old riches and virtues and states that 'nobility consists in having an old family with inherited and acquired wealth'. Poggio in his dialogue on nobility says that nobility combines three factors: old wealth, excellence of blood, and a record of service in public office.

In the company of these writings even Petrarch's admittedly renunciatory works such as the De Vita Solitaria, Suum Secretum and the $D e$ Remediis have elements that mark a break with the medieval religious otherworldliness. Petrarch's De Vita Solitaria, which was copied so enthusiastically in the monasteries by monks who saw in it the glorification of their mode of life, in reality did not preach the devout quiet life of the cloister, but the refuge from disturbance of the scholar devoted to study, the luxury of intercourse with the beauties of nature far away from the noise of men. It is the flight of the aesthete from the philistines in the city, who enjoys the secluded life of his villa and cultivates his garden. In contrast with Roger de Caen's Carmen de Mundi Contemptu, learning is not here counted among the valueless goods. Petrarch is quite express in his view that reading and writing are his major passions.

In the Suum Secretum many worldly tendencies can be found. Petrarch's 'rest' is not really God but primarily rest for his overwrought nerves. Though the work is very revealing about Petrarch's personality, it is not a profound religious confession comparable to the depth of Augustine's Confessiones. It remains fundamentally a rhetorical exercise ${ }^{1}$ and displays Petrarch's fascination with his emotional experiences.

The De Remediis presents a system of practical moral wisdom and is typical of the humanists' programme in its combination of rhetoric, history and moral philosophy. Though the actual solution offered is in

1 See A von Martın, 'Petrarca und Augustın', Archiv fur Kulturgeschichte, XVIII, (1928), pp. 57-96. 


\section{LITERARY GENRE AND THEME}

nearly all cases renunciatory in spirit, Petrarch's detailed consideration of the worldly goods is worldly in itself and asserts what he denies in his express statements. Though in Suum Secretum Petrarch admits he has qualms about his pursuit of classical studies-just like St. Jerome and many other medieval lovers of the classics - the reverse view is evident in the implied values he extols in the $D e$ Remediis. In his discussion of nobility in II, dial. 5, his fascination with classical heroism and personal fame is paramount. He extols the virtues of the Romans as incitements to his compatriots. In this dialogue, after his relation of Ventidius' military successes, he says: 'These are the steps to rise by, these are the degrees unto virtue, whereby men are advanced, not only to glory and higher fortune... but also enthronized within heaven.' This is a far cry from Roger de Caen. In II, dial. 9, he illustrates his dictum that only virtue is the supreme art against all misfortune and poverty with the example of the philosopher Aristippus. When cast by shipwreck on a foreign shore, he immediately won affection and renown through his merits as a scholar, and was provided with all he needed. Virtue and its rewards have a firmly established worldly meaning here. ${ }^{1}$

It is interesting to see what the English adapter did with these sections. 'Virtue' in the sense of 'excellence', with the related notions of 'personal or public merit', would not agree with his notion of the prevailing sense of the word (but see OED s.v. virtuous). By way of explicit commentary he inserts passages contrasting fortune with grace and thus shows how to him nobility arises from moral excellence and reliance on the grace of God.

It is clear that in Petrarch's ascetic works much of the older period remains by the side of his essential innovations. There are indications that to Petrarch the dour ascetic views were not as vital as they are sometimes made out to be. As so often happens with notions on the brink of being replaced they are stressed with a rigidity which thrusts the door wide open to a change of standards. Depending on the reader, however, it was easy enough in interpreting them to lean to the one side or the other in emphasis. In the England of around 1400, where Poggio could still sneer at barbarous Englishmen, there was as yet no audience for Petrarch's humanistic tastes. This is illustrated by the changes thought necessary in the English version of the De Remediis.

1 See also K. Heitmann, Fortuna und Virtus, who notes the ambiguity of Petrarch's conception of 'virtue' (P. 80) 

THE TWO TEXTS PARALIE 
II. Franciscı Petrarche poete Oratorısque Clarıssımı consolatın operıs su ad Azonem de Remediss utrusque fortune Liber secundus de Adversa fortuna disputans feliciter incipit

\section{DE DEFORMITATE CORPORIS}

II. Dolor Egisse mecum nimis illiberaluter naturam queror que deformem

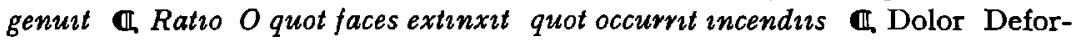
mem genuit natura $\mathbb{I}$. Ratio Non dedit quod delectet si quod prosit dedit satis est mitte querelas $\mathbb{0}$. Dolor Non dedit forme gratiam natura II. Ratio Dare nolunt quod egritudo corrumperet quod senectus enperet Dedit forte quod nec mors ipsa contingere audeat II Dolor Formam corporis natura negavit a. Ratio Si formam anımı largita est maxımı debitor exıgui repulsam alta mente despicito et offensam speculı conscientia solare (II Dolor Invidit natura formam corporis $\mathbb{G}$, Ratio Non invidit sed erubuit dare quod quotidie minuatur et pereat Vera liberalitas mansuro munere noscitur Putria et caduca azar etram donant Forma fugax et fragile nature donum paucis ad utılitatem multis ad pernitiem nullı ad salutem veramque gloriam data est (I. Dolor Forma mihi corporis negata est II Ratio Raro admodum forma insignis honestasque uno sub lave habitant Bene tibi accidit si peiori exclusa

20 hospes melior tecum est \&. Dolor Nullum forme decus obtigit $\mathbb{a}$ Ratio Quid hinc doles aut quid penitus sanctum piumque anımo volvis? In quod tıbi necessanam aut omnino usuı et non potius impedimento esse corporis formam putes? Mullos forma fecrt adulteros castum nullum Multos per lubrica voluptatum duxit ad infamem mortem qui deformes sine dedecore periculoque vixissent Et quid multos dixi? Innumerabiles in discrimen fere omnes in crimen trahit $\mathbb{C}$. Dolor Cur me deformem genut natura? đI. Ratio Ut ipse te ornares ac formosum faceres ea forma que tecum esset in senıo in grabatulo in feretro in sepulchro essetque tua non nature laus aut parentum Pulchrius est pulchrum fien quam nasce Illud enim casus hoc

so studı est (II. Dolor Corporis multa deformitas me premit II Ratio Deformitas quidem hec apud quosdam infelicitatis quedam portio est $T u$ crede dicentibus non deformitate corporis fedari animum sed pulchritudine animi corpus ornari Non te hoc igitur inhonestat aut premit sed honestandi anım materiam assurgendique aditum per virtutes aperit II. Dolor Deformem natura

s5 parens genuit II Ratio $S_{1}$ deformem Helenam genusset vel ut viros loquar si deformem Parıdem fortasse Ilion adhuc staret II Dolor Deformis in luce editus queror $\mathbb{C}$. Ratio Pauci bonı formam corporis amarunt nullus optavit quidam etiam proiecerunt Quod fecisse laudatur ille Thuscus adolescens qui precları vultus eximıam speciem quam suspectam multis 40 adversamque fame sue senserat et pudicitie aliene illatis sibi sponte vulnenbus deformavit quam tibi dissimilis qui id optes quod ille sibi abstulit et quo rarı nunquam innocue usı sint (II Dolor Forma careo $\mathbb{a}$. Ratio Tutius est caruisse quo in experimentum tui anceps ac laboriosum sepe

7 Ven quod occurnt 
177b // Nature was not my frende pat suffrede me to be bore of vnsemeli schap.

đI. RESOUN: Nature was not pyn enemye for pat pou wantes pi delizt he dede it for pi profizt. Wenne synne wolde asaile pe pi 5 deformite ofte withstondip. Pyn vnsemelynesse is a poole pat sleknyp helle brondes. Kynde wolde not ziffe pe pat ping pat be siknes my3t be corupt ne pat age myght be neme pe. Rote pinges $\mathcal{E}$ faylynge are $z$ iftes of negardes. He hap openyd to pe. pe ocasion of vertu. For faire fetoured bodi $\&$ clennesse of souzle selden nestele 10 pei to gedere.

đI ADUERSITE: Whi was I born so vnschaply?

II. RESOUN: For pou schuldest honoure pi self with sich a beuzte pat schulde kepe pe fair. pat wanne pi face schal rongle \& alle pi lemes schal feblen. pat is fairenes of souzle pat deth may not quen-

15 chen. Doow bou were born wonder schaply whi schuldest pou be preised? Peynte pi souzle with vertues $\&$ panne art pou pank worthi. for pat is of pyn owne studie. He pat wolde be comendid for his schap is semely spoilip nature of his rizt.

đ. ADUERSITE: I ham had in despit be cause I ham vnsemeli.

20 C. RESOUN: As noping pat longep to man is glorious but vertu: so noping is contemptible in man but synne alone. With no shap. with no stature is vertu at debate. Deformite of bodi defilith not pe souzle. but pe fairnes of pe souzle honoureth pe body. Semelynesse made neuere 3 it man or womman chast. Hadde Thamar Dauid is 25 dowter ben a fouzl leyth damesele. behap Amoun here bropur. hadde here not oppressed. Lufly schap of bodi: is lemman to lechery. Seyntes lete but lizt be bodili bewte. For litil worth is pe blosme: 178. but ony frute folwe. //

II. ADUERSITE: I wolde fayn be faire.

so III, RESOUN: Strife not penne a zeyn kynde lest pou be fouzlere. Pese wymmen pat peynten hem self with crafti wateres. how fouzle pei ben to loken vp on: experiens schewet. Whanne pei of borwed

1. Nature: capital illuminated.

9. MS. faire superscript between For and fetoured with caret in between.

25. MS. fouzl in margin and caret between a and leyth. 
venturus sis. Multis forma nocuit: cunctos exercuit: quosdam post insultus varios mollivit et vinci faciles dedit atque ab honestate transversos in culpam trusit. II Dolor. Deformis et brevis nimium statura est. II. Ratio. Non est ut reris prosequendum querelis incommodum longe conspectior est statura: brevis

5 expeditior agiliorque. If Dolor. Statura perbrevis est. II Ratio. Quid vetat: ut in parva domo magnum virum: sic in parvo corpore magnum animum habitare? $\mathbb{1}$. Dolor. Corpus exiguum est. I. Ratio. Id scilicet lamentaris quod teipso non es ornatus sed levis et facilis et ad cuncta versatilis. II Dolor. Pevexiguum est corpus. $\mathbb{\mathbb { I }}$. Ratio. Quis unquam de exigua conquestus est sarcina?

10 Justa hercle dolendi causa quod non pressus mole corporea sed indutus: neque ipse tibi tedio sed usui sis. II. Dolor. Contemptibili sum statura. đ. Ratio. Ut gloriosum nihil nisi virtus: sic contemptibile nihil nisi vitium. Nullam virtus respuit staturam. II Dolor. Exigua corporis statura est. II Ratio. Non staturam corporis virtus exigit sed animi. Hec si longa: si recta: si ampla: si magni-

15 fica: si decora est: sit illa altera qualiscunque: nihil ad rem: Non solum domi sed ne militie quidem nisi magis obesse videretur. Nosti ut Marius summus dux: non longos sed torosos et validos milites eligebat. Id quam feliciter: quam consulto faceret: crebre et ingentes indicant victorie. Habet corporum proceritas maiestatis plusculum non vigoris. II. Dolor. Brevis est statura.

20 II. Ratio. Hec non impedit quin vir bonus et magnus esse possis. Insuper et rex si sors tulerit et imperator. Et si enim Africanus Scipio celsus corpore: Julius Cesar statura fuerit excelsa brevi tamen Alexander macedo et Augustus Cesar nec eorum magnitudini brevitas obfuit: nec detraxit fame. II Dolor. Vellem esse altior et maior. II Ratio. Assurge animo cresce virtutibus: maior eris atque altior. Hoc utilius hoc facilius incrementum. II. Dolor. Cuperem esse formosus. C. Ratio. Disce amare atque optare meliora. Stultum est amare periculum suum: Stultum optare quod nullo studio queri potest. Nempe si contra naturam formosus fieri studeas: nil ultra proficies quam ut deformior videare. 때 Dolor. Formosus esse nequicquam nitor. $\mathbb{I}$ Ratio. Nitere autem bonus esse:

so Id non frustra enim facies. Hoc inter multa precipuum virtus habet: queri potest: eripi non potest. Cum reliqua in arbitrio sint fortune: nec obstante illa queri valeant nec servari: Sola virtus fortune legibus libera est atque illa obluctante clarius nitet.

\section{DE IMBECILLITATE}

II Dolor. Natura me genuit imbecillem. II. Ratio. Ut in putri vagina ensis ferreus: sic in fragili corpore fortis sepe animus latet. $\mathbb{0}$. Dolor. Imbecillis natus sum. II. Ratio. Non eris idoneus vectandis oneribus aut arvo fodiendo: sed honestis studiis sed iustis imperiis. Sic in navi robustior quisque remum agit: 40 at prudentior clavum regit. Vita quasi navis rerum fluctibus et mundi pelago iactata suos remos habet suumque gubernaculum: $A$ vilioribus repulsus officiis ad nobiliora convertere. $\mathbb{0}$. Dolor. Imbecillem genuit natura. (I. Ratio. Quid si robustissimum genuisset? An perpetuum robur erat: an non robustior egritudo? Ut sileam casus innumeros qui repente totum hominem debilitant 45 atque enervant: Animi robur optabile est: quod nec dies minuit nec fortuna. 
her. feynen hem hornes panne falle pei fro faymesse to pe liknesse of Lucifer. $\&$ forfeten a 3 en pe lore of Petir $\&$ Paule. Bif pou list to be faire: lerne to leue weel. Pyn vnlusti schap pou pleynes on so meche! is lent pe but for a tyme. With jnne a fewe daies wole deth 5 sende his messanger $\&$ robbe pe per of. and 3 if pi souzle penne be clopid in pe garnement of charite. at domes day whan it schal be knyt to pe cors a zen. pi bodi schal be enduet with so gret a clernesse: hit schal be bryghter seuene sithe panne pe sonne is now. Denne schal deformite be exiled per fro for euere. Pus enformeth vs 10 holy wryt \& Austeyn pe doctour.

(I. ADUERSITE: I ham of litil stature.

व. RESOUN : Pat is no cause of grucching. Litel cors. litil cariage. Dou art no burpen to pi self. Glorious to pe eyze is a long stature. but more swipper is pe schort comynly \& more spedi. What for15 bedep a meche man to inhabit a low hows? So may a gret souzle wonen in a schort body. Nouzt I mene pat pe souzle schulde of quantite be gret. but gret of kunnynge of goodnesse $\&$ of manhod. Hit harmep not pat pe bee is but a litil thing! his hony $\&$ his wex recorden of his vertu.

20 II. ADUERSITE: Mi stature is but litil.

0. RESOUN: Pere inne is no impediment but pat pou mai be a good man. a gret man ze a kyng. an emperour 3 if god wele it suffre.

$178^{\mathrm{b}}$ Gret Alisaundere was no larche man. 3it pe brefnes of $/ /$ his bodi hyndirde not his fame. Wanne Samuel was sent in to Bedlem to enoynten on of pe sones of Iesse to gouerne Israel as god hadde preuyded he was beden be pe lord he schulde not take to pe semblaunt ne to pe altitude of pe stature of Helyab but litil Dauid was ennoynted pat afterward reygnede. Pe litilnes of pis Dauid lettid hym in no poynt to haue pe victorie of Goly pat was six cubites so long.

I. ADUERSITE: Mi desir were to be heyzere.

(I. RESOUN : As pou encresis in age: encrese in vertues. panne pou schalt be verili more. \& welde a worthi hygnesse.

II ADUERSITE: I ham feble of bodi.

95 II. RESOUN: A fyn sweerde is ofte houzsed in a roten schepe. $\&$ a strong souzle herbored in a feble bodi. Bou art not apt to turnementes or to wrastelinges. Perauenture pou hast abelte to honeste

27. One or two letters erased before litil. 
đI. Dolor. Corpore imbecillis sum. I. Ratio. Animum fove atque exerce suis artibus quas meliores esse diuturnioresque non ambigis: Laborem corporis linque ruricolis: nautis: fabris. II. Dolor. Nulle mihi ab origine fuere vires. a. Ratio. At idipsum non habuisse: quam perdidisse tolerabilius est. Nempe 5 si fuissent non mansissent. Nam et Milonis senuerunt vires: et Herculis senuissent. Non sic Socratis: non Solonis: non nestoris: non Catonis. Melioribus utere: Nil potest delectare magnum animum quod non duret. II Dolor. Corpusculum imbecille est. If Ratio. Si organum inhabitanti animo sufficiens fuerit satis est virium. Corpus nanque propter animi servitium fecisse naturam:

10 Nemo tam corporis servus est qui nesciat id si proprio munere fungitur: Quid accusas seu quid amplius requiris? Nam qui ingenio fragiles: corpore prevalent hi beluis proxime accedunt: et sepe quod miserum est: aliis serviunt. Sepe vero quod miserrimum : atque ubi humane miserie summa est: animum ipsi suum servire corpori suo cogunt servitute fedissima. (4. Dolor. Corpus invalidum est mihi. T. Ratio. Vera et generosa vis hominis in animo est. Corpus est quasi quedam domus animi quam robusta: quam fragilis: nihil ad hospitem: paucorum precipue dierum: modo ne corruat: tunc migrandi necessitas in aliud: idque perpetuum domicilium hinc exclusos transfert. Plus dicerem si plus capere posses nec vulgari strepitu prorsus obsurduisses:

20 Corpus ipsum non animi domum esse sed carcerem: nec amicum certe sed domesticum hostem: cuius tibi fragilitas sit optanda quo tu liber maturius sis ac victor. II Dolor. Nulle sunt mihi vires. II Ratio. Nulle penitus dum valeas: non sunt: quod si non vales: alia est querela. Non ergo nullas vis dicere: sed parvas vires. Non es robustus: ut ille coetaneus turs: neque is: ut ille alius 25 neque ille ut bos utque elephas: Suus cuique virium modus est: cuique quod sat esset indulgentior natura distribuit parens optima: et suorum fetuum amantior quam quisque sui. Non potestis de defectu queri de imparitate querimini. Turbidum genus et querulum: qua sublata mundi decor intereat necesse est: sic quod optimum est in rebus id fertis egerrime.

\section{a. DE ADVERSA VALITUdinE}

\section{DIALOGUS III}

III Dolor. At adversa valitudo est. III Ratio. Quod expectabam audio: cognate etenim sunt querele. At si caro spiritui hostis est vicissimque contra se militant: Quod in se expertus ille magnus veri amicus: in omnibus verum dixit: conse-

35 quens est ut quod alleri obest: prosit alteri. Quod si spiritus carne nobilior meliorque est: cui maxime sit favendum vides ac fortassis intelligis valitudinem: quam adversam dicis esse prosperrimam. II. Dolor. Invalida valitudo est. II. Ratio. At est valida hortatrix parsimonie dehortatrixque libidinum: et magistra modestie. II. Dolor. Mala est valitudo corporis. II. Ratio. Si valitudo 40 animi bona est: pone sollicitudinem: quicquid corpori evenerit: salvus es. (1. Dolor. Corpus egrum infirmumque est. đI. Ratio. Multis ad salutem anime profuit corporis egritudo. Ille vir altus ex humili: ex aquis vectus ad sydera: celique claviger effectus: cuius umbra sola morbos corporum molestiasque pellebat: Interrogatus aliquando cur filiam ipse suam gravi morbo pressam sineret: 45 respondit: Sic expedit ei. Tu quid scis: an et tibi sic expediat? $\mathbf{6}$. Dolor. Diu 
studie. Redines of conseil $\&$ prudence of gouernaunce hath rered vp many feble \& made hem to sitten with princes. Doouz pou were al so strong as Sampson whas zif seknesse \& age hadden fowten a while with pe: pe victorie schulde be heren. Josue Judas Machabe

5 Ector \& Arthour. deth hath taken hem presoneres. Verrei strengpe is in pe souzle. for it is perpetuel 3 if it be wel norisched. In pinge pat moste nede failep a gentil souzle hap no delit.

II ADUERSITE: I haue but litil strengbe.

II. RESOUN: Perchaunce pou art not so stronge as he pat is pin 10 euenehelde. ne he pus as an opur pat is of euene age. nepur he 3 it 179 as an hors or an // olifaunt. Eche ping hath his mesure. Poow strengpe haue schewede pe glad semelaunde. $z$ if kyndly wit be inned with pe. pou hast pe bettere gest. Mightiboned men pat be dulwitted in pe naturel ordere of men kepe $n$ pe lowest degre. for in pat drawe pei next to bestis apt to bere lordenes.

đI. ADUERSITE: Mi body is ful feble.

II. RESOUN : 3if hit be an instrument sufficient to serue pe souzle: it is strong jnow. for per to was it ordeined. It is non conseille to the. but 3 if pou haue forzeten. how Paule pe apostle wrytip. pat pe

20 flesch is rebel a zens his lord pe spirit. Sithen pe bodi penne is pi famyliar enemye. his debilite dop meche for pe. For with pe lasse labour maist pou be maister.

\section{OF SIKNES}

II. ADUERSITE: Seknesse holdep me lowe.

I. RESOUN : Panne nedith pe not to borwe a merour to see what pi self art. Ping pat may not dize: may not be sik. Boow siknes be non lithsum fere: a feipfullere felow found pou neuere to warne pe of pi perelles. As often sik as often sumned to zelden a rekening of pi beli be fore pe hize juge. 3if pi souzle haue good hele kepe it bisily. \& what so happeneth of pi bodi pou schalt be safe.

II ADUERSITE: I suffre greuouzs siknesse.

a. RESOUN: Prey pacience helpe pe to bere \& lizt schal be pi birthen. Were pou frende to pi souzle. pou pleynede pe not of pis.

24. Seknesse: capital illuminated. 
corpore sic affectus sum $\mathbb{\text { II }}$ Ratıo Ille ıdem de quo loquor fuliam mox ut tuto sanam fierı posse cognovit et sanavit et sanandis alıs hablem fecit Et tu facito ut secura tibi sanitas tua sit fortasse sanabere Denique quod tuum est anımum cura celestrque medico curandum offer De reliquo unum 5 hoc intrepide dixerim et si non quod iuvat at profecto quod expedit spera (II. Dolor Valitudo anxia est a. Ratıo Est que oblivionem somnumque discutiat et torporem abigat (I. Dolor Valitudo infirma est (I. Ratio In infirmitatibus gloriare et virtutem perfice Duo hec unius magistri ore didicistı II. Dolor Valitudo misera est $\mathbb{\mathbb { I }}$. Ratio Comes inuucunda sed fidelis que te 10 crebro vellicet iter signet et conditzonis admoneat optrmum in periculis monitor fidus (II Dolor Valitudo corpons extrema sine remedio est II. Ratio Sile et gaude rumoso carcere vinctum te egrediere facilıus ac cutıus 
Wilis pe flesch \& pe spirit wrastlen to gedere: hinderyng of pe ton is forthing of pe topere. Fauere (pe) betere. Hadde neuere infirmite haue asailed Job \& Tobye: here holinesse hadde not $z^{\text {it }}$ be fully opened.

5 đI ADUERSITE: Me heuyep // with my sekenes.

II. RESOUN: Greuous infirmite makip sober souzle. A wantoun wille to be refreined nedith a bridel of arest. Not alwey pe fader strokes his sones heued. but wanne he findep him fawty rebukip him with a scour(g)yng. Depertip not pe fleil be corn fro pe schaf?

10 A bittur drinke purcheth wikkid humour. Wel worth pe wand pat makip wilde childer tame.

II ADUERSITE: Whi haue I infirmite? I synnede neuer gretly.

I. RESOUN: Whi is a wilde colt teyzed pat neuer harm dede? Pat we be not ouer flowed with pe salt water: is long of pe see banges.

A bitinge plastere conseruede pe apostele after pat he had be rauyched to pe pridde heuene fro pe swellinge of veyn glorie. Jueles pat ben vnder lok in stronge bounde wycches arn in saf warde. How precious a juel pat pi souzle is prouep pi redempcion. Pe wisest marchaunt of pe worlde paizede perfore a copious raunsum. \& for 20 it schulde be surely kept. pou art leid in goddisbondes. Grucche not pat Crist hath loked vp fro pefes his chosen tresour.

II ADUERSITE: I prey to god after hele. \& I ham not herd.

II RESOUN: Neper Paule hadde his askyng. wanne he preizede for remocion of siknes before seid. For pus pe lord answerede: Mi grace sufficyp to be. for vertu in infirmite is perfitly mad. A prudent phisician with drawep from his pacient ofte sithes for his beste ping pat is likerous. Seint Peter be whom god helede many maladies myraculusly suffrede his dowter Pernylle to langure in a palsie.

180 Wenne Titus him freynede what was pe cause. // he answerede pat so (it) was to here expedient. Paule 3 af him not preizere to hele sik Tymope. but he enformede him for to vsin medicyne. What wost pou. what is speedful to pe? Comytte pe cure of thi bodi. to pe souereyne leche $\&$ douzteles triste pi lizf schalt pou haue. or elles god schal dispose. as bettere for pe.

(1. ADUERSITE: Mi siknesse is incurable.

2. MS, pou.

9. MS. scourryng.

10. MS. pe in margin with caret between worth and wand.

30. $M S$. is. 


\section{G. DE IGNOBILI PATRIA}

\section{DIALOGUS IIII}

đI. Dolor. Ignobilis patrie civis sum. I. Ratio. Esto tu nobilis: Nam nil vetat: nihil cum patrie nobilitate tua nobilitas mixtum habet. I. Dolor. Parve urbis

5 incola sum. IL Ratio. Et magne urbes parvos cives habent: Immo fere ex his constant: et parve magnos quosdam habuere. Quin in silvis abiectus ac nutritus Romulus: omnium urbium reginam urbem romam condidit: quam evertere voluit in maxima urbe genitus Catilina. II Dolor. In exigua patria natus sum. I. Ratio. Magnificare illam stude. Nihil eque civitates amplificat

10 ut civium virtus ac gloria. Qui hoc edificiis aut fertilitate melius atque opibus fieri putat: fallitur: ut singulos viros: sic et urbes et regna et imperia : non vetustas: non turres ac menia: non platee: non palatia ac templa marmorea non statue: non picture: non aurum non gemme: non campi legionum et classium pleni portus: non peregrinis referta mercibus emporia: et lucri

15 amore equor omne sulcatum: non postremo civium forma vel numerus: non rerum copia exundansque cibis forum: non purpuree chlamydes virorum: onusteque miris cultibus: non fastus: non delitie: non voluptates: sed virtus sola nobilitat: gestarumque rerum fama quam viri pariunt: non muri. ㅈ. Dolor. Parvi municipii civis sum. II. Ratio. Nescis Biantem Pirenneum fuisse:

20 Pythagoram Samium: Anacharsim Scytham: Democritum Abderitem: Aristotelem Stragyritem: Theophrastum Lesbium: Tullium Arpinatem. Chous Egei maris brevis insula: et poetam non ignobilem Philitem tulit: et medicorum patrem et sculptorum ac pictorum principes: Hippocratem scilicet et Phidiam et Apellem: ut intelligi possit ingeniorum magnitudini locorum

25 angustias non obstave. II. Dolor. Ignobilis est patria. II. Ratio. Nobilitare the illam pro virili parte si velis: potes cum te illa facere non possit ignobilem. Nec Nume quidem Pompilio ad romanum regnum: nec Septimio Severo ad imperium obstitit soli natalis humilitas. Summo hominum Augusto: et si recens romana: quia ipse scilicet in palatio natus sit: origo tamen gentis

so antiquior Veliterna est. Gaio Anthias: Vespasiano autem vici incogniti reatini. Contra vero Larisseam famam vulgavit Eacides: et Peleum a seculis fuscum nomen atque humile: quod Philippus erexerat: Alexander ad celum tulit. Non satis est civibus obscuritatem patrie non nocere: nisi civium claritas patrie prosit. Asylum ignobile atque opus pastorium roma fuit: que non ante

35 claresceret quam res illam geste et suorum virtus excellens civium illustrasset. II Dolor. Obscure patrie sum addictus. II Ratio. Lumen virtutis accende: quo inter tenebras enitescas: in quibus hoc saltem boni erit: ut vel parva luce clarissimus videare: sic vel illa te clarum faciet: vel tu illam. $\mathbb{H}$ Dolor. Humilis patrie habitator sum. II. Ratio. Esto et tu humilis habitatorque tui animus

40 humilis sit. Habes publice matris exemplum: ne te nido latius extendas nisi his tantum quas tibi virtus alas fecerit. His enim uti licitum: usosque feliciter

38. Ven. vel tu illa. 
a. RESOUN : Panne glad be pi spirizt. his presoun is ruynouzs he schal pe sunnere be deliuerid.

\section{OF VNNOBLE CUNTRE}

(I. ADUERSITE: I whas born in a cuntre of litil reputacion.

II. RESOUN: Be pou pi self noble \& pou art neuer pe lesse worthi. Pou may worschepe pi cuntre. $\mathscr{F}$ it may do pe no vilany. Of pi nobilite $\mathcal{F}$ of pe nobilite of pi cuntre may no medle be mad. Pe dymmere pat pe fame of pi cuntre is: pe lithlier may pe bryztnesse of pi name be sene. for in derk place. litil lizt is sone aspied. Pis 10 witnessith pe storie of pe good woman Ruth. Her vertu is now more knowen porw al holichirche be cause pat sche was of pe region of Moab: panne pat sche hadde be born in middis of Ierusalem. Lucifer pou may be a schamed pat pou where made in heuene. for \& pou haddist ben made in erpe: pi falle hadde semed pe lasse.

II. ADUERSITE: I whas born in a litil porpe.

II. RESOUN: Often tymes grete treis springen vp in streyt gardeines. Narwnes of place withstandep nepur wit nepur vertu. Aristotele \& Ypocras men of gret sciens. were of smale townes.

180 Ouzr sauyour. chese not. to // be born in Ierusalem nor in Rome pat 20 were rial cetes but in pe town of Bedleem pat was meche lesse of fame. Pe nobilite of a cete stondep neper in hize toures nor in grete richesses: but in famouse storye of pe induellande. Place makep no man holy! but man makep holy place. Sum men pride hem alle one of nobeley of pere cuntre. Bat is a frenetik pride.

4. Aduersite: Capital illuminated.

12. MS. pat superscript between panne and sche with caret in between. 
complures modo diximus. Proinde mortalis hoc saltem insolentie frenum tene. Quidam de sola patrie nobilitate superbiunt: Stultum genus.

\section{a. DE ORIGINIS OBSCURITATE}

\section{DIALOGUS V}

5 G. Dolor. Obscuris parentibus natus sum. ब1. Ratio. Non est forsan ut tu reris odiosa conditio: nescio an et optabilis ignobilem nasci: utramvis vite viam spectes. Nam seu voluptatibus obsequi: vulgique vestigiis tritum iter sequi statuis excusabilior fiet veri ducibus domesticis carens error cessabitque improperium illud acerrimum degenerantium a parentibus claris: eo quod nulla tibi domi sit claritas quam obscures: Sin virtutis semitam raro pede signatam eligis: eo clarior fies: quo maioribus tenebris pressus ac circumventus emerseris: tota claritas erit verum particeps tuarum ullus occurret. Nullam partem glorie decerptura erit imitatio. Nihil tibi parentes eripient: nihil avi proavique: nihil consiliarii ac magistri: Quicquid bene gesseris: solus inde fa-

15 mam metes: solus inde laudaberis: solus auctor generis fundatorque vocaberis: quod non fieret si nobilis natus esses. Vides ne igitur quanta tibi nove laudis occasio data est: Nobilem per te fieri: et nobilitatem dare non accipere. Dabis hoc posteris tuis ut nobiles nascantur: quod parentes tibi non dederunt tui. Plus est multo nobilitatem fundare quam fundatam ab aliis invenisse. If Dolor. Nova et rudis origo est. $\mathbb{a}$. Ratio. Atqui clarior est habitus ille pastorius urbis rome conditor: quod in silvis arcem posuit: et facili culmo exiguam ac squallentem regiam texit: quam tot postea principes qui ingentia menia testudinesque marmoreas atque aureas erexere: tanta semper novitatis egregie ac magni principii laus est. (11 Dolor. Ignobili primordio genitus sum. (II. Ratio. Stude ut fine sis nobili. De principiis enim labor: de fine fructus qui si immaturus carpitur: longevus esse non potest. ㄸ. Dolor. Radicem glorie precidit ignobilitas. II. Ratio. Non precidit quidem: sed infodit altius ut validior licet serior surgat. Ceterum non ignobiles modo sed ignotos ex omni genere hominum dabo: qui virtute atque industria evasere notissimi. Et sane

3o si verum nobilem virtus facit: non intelligo quid quemque volentem fieri nobilem impediat: aut quid ita facilius sit nobilitare alios quam seipsum. II. Dolor. Ex ignobilibus parentibus descendo. I. Ratio. Quid Socrates: Euripides: Demosthenes: quorum primus marmorarium patrem habuit: obstetricem matrem: secundus matre patreque: ultimus non solum humilibus sed incertis. Vester ille Virgilius rusticanis parentibus fuit: Nec se libertino ac precone patre natum Flaccus erubuit: Ambo tamen ad insignem gloriam et summi principis gratiam pervenere: usque adeo ut cui reges omnes colla submiserant: cuius e manibus magna omnia poscebantur: atque unde omnium ferme mortalium precipueque nobilium spes pendebant: cuius demum

40 familiarem promeruisse notitiam summis licet hominibus summum erat: Ipse horum duorum ignobilium: quos romam scilicet Mantuanum Venusinumque rus miserat amicitiam et convictum ceu grande aliquid blandis ac dulcibus epistolis flagitaret: et quam multos tunc in palatio nobiles ut sepe sunt inutiles atque indoctos credimus fuisse: quibus horum nobilis ignobilitas atque invidiosa: nec immerito videretur. (.) Dolor. Parentibus sum obscuris. 


\section{(1) OF PORE BIRPE}

II ADUERSITE: De stok of my natiuite is simple \& pore.

II. RESOUN: Mater of mekenesse is non odiouzs condicioun. What menep pe but vanite pat pou wolt pat men talede of pe pat were come of higze blod? Fro depe rotes and derke proceden deleitable braunches. 3if fortune or vertu profer pe frenchip pou may lefulli ascende $\&$ if hit happe pat pou sitte in a place of dignite pi glorie schal (pe) not be denyed. Among pi progenitoures. pou schalt haue alle pe hole preisinge. What so euer pou weel dost pou schalt repe pe pank pi silff. \& 3 if pou haue lawful issu pou schalt be kald a foundere of a gentil lenage. wich name pou mayst not kalenge be rizt 3 if pi aunceteres hadde ben noble. Deme now wepur is fairere to zeue cleernesse with pe sunne. or lizt to borwe with be mone.

(10. ADUERSITE: Homly folk \& rude brouzt me in to pis worlde.

II. RESOUN : Pou art pe more excusable 3 if pou be rude pi silf. $\delta$ zif pou be man of sich honeste pat pou be worthili magnified pe 181 brizt bemes of pi fame schal worschipe // alle thi kynne. Virgil was of low kynne. 3 it pe sors of his wisdom was of so swete an odour? pat it was deynte to princes to haue knowlech of him. Pat 20 pe sones of pore men gouernen may riche remes. telle it for no typingges: for it is no nouelte. Azenward pe nobleye of many gentilmennes children suffren sich a clips pat wereof pei profiten vnnepe it is perceyued. Emperours \& kynges sitte pei neuere so hize. here trone tremblip vndur hem but vertu holde hem vp. Fiche 25 pi feet per fore in pe path of vertu for be his grees maist pou most sekirli ascende.

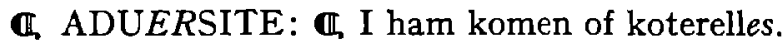

व. RESOUN: Open it is pat fortune scheweth not chere jlik to alle men at here first komynge in to pis world. for summe sch(e) lullith in 3o clopis of gold $\&$ on summe sche vouchep saf vnnepes a fewe ragges.

2. Aduersite: capital illuminated.

8. MS. schal not be not denyed.

20. MS. riche in margin with caret between may and remes.

28. MS. openen.

29. MS. sch. 
II. Ratio. Non movent animum hec exempla: Altioribus agam. Marcus Cicero: ut de illo scriptum est: ex ordine natus equestri de radice humili per egregias artes perque honestos gradus ad consulatum venit: quo nescio an alter unquam salubrior rei publice consulatus fuerit. $\mathbb{T}$. Dolor. Rustica et 5 ignota patrum series est mihi. a, Ratio. Sordent hec ut video: Altius etiam nunc aspiras. Certe et Marius rusticanus vir: sed vere vir ut concivis suus ait Cicero: diu arator apud Marsos fuerat: rome septies consul fuit: Tanta gloria: ut bis Italiam obsidione et metu servitutis liberasse eum compatriota licet idem suus vere dixerit: et Marcus Cato plebeie vir originis parvique opidi diu quidem obscurus incola: post in maxima urbe clarissimus advena: mox civis eximius et consul et censor fuit. Si ne id quidem satis est et fortasse regnum cogitas: Profecto neque illud sperare suffragio meritorum humilitas vetat originis: Tertium et quintum et sextum romanorum regum ad memoriam refert Tullus Hostilius: ut probati perhibent auctores: et si apud alios de illo tale nihil scriptum sit: infans in agresti tugurio educatus: in adolescentia pastor fuit. Tarquinius priscus patre negociatore advena: nec Italice insuper originis. Servius Tullus: serva: quamvis: ut alii volunt: captiva quidem: alioquin vero nobili matre natus: virtute regnum rome meruit. Nec miraberis si Platonicum illud tenes: Neminem regem non ex servis: neminem servum non ex regibus descendere. Sic res hominum: longa etas ac fortuna permiscuit. Sileo ceterarum reges gentium: e pecudum gregibus vilissimarumque artium tabernis ad inopinum subito diadema subvectos. Alexander Macedo hortulanum in Asia regem fecit. Et fuit ex illis actibus laudatis iste non ultimus. Contraque alios sileo: e regni fastigio ad servitium usque pro-

25 lapsos. Sic suas res fortuna moderatur: tamen plurimum potest virtus. $P e r$ illam tuto conscenditur ad supremos gradus cuius calle deserto: sciant reges se in tremulo stare neque descensum modo instare sed ruinam. Que nam igitur: ut ad te redeam: ista calamitas nascendi cui nec spes regnandi eripitur nec successus? II Dolor. Obscura de radice prodeo. II Ratio. Omnis radix obscura et 30 squalida est: unde tamen et floridi et frondentes rami prodeunt. Non unde quicquam prodierit sed quale sit queritur. $\mathbb{a}$. Dolor. Parentibus infimis natus sum. $\mathbb{a}$ Ratio. Sentio summum ad imperium stilum vocas. Septimius Severus de quo supra diximus: equestris et ipse ordinis. Helius pertinax et ipse libertini filius et lignorum vilis utique negociator mercis: uterque romano prefuit

35 Imperio: cui et Philippus pater ac filius Arabes humillimi generis : et Maximinus et Maximus prefuere. Obscurissimis ille parentibus ac barbaris : quorumque cum arepto imperio: puderet: hic ferrario an lignario patre genitus incertum. Certe Vespasianus inter bonos principes numeratus: e non clara stirpe clarissimus et rempublicarn gessit eximie: et duos ex ordine filios successores imperii virtutis unum habuit: Quamquam quid minora prosequimur: cum super ipsius Augusti cesaris origine ambiguitas multa sit? Summa est humane cursum sortis origine non preverti: Undecumque licet assurgere: seu fortuna manum porrigat seu virtus. II. Dolor. Humile nimis atque infimum genus est. II Ratio. Quod ad humane potentie gradum spectat

11. Ven. Sine. 
But grace is of a more gentil condicioun. What mannes childe pat euere hit be pat komep to pe fonstone. sche welkomep hit worschipfulli of clenly a raizeth it $\&$ alle po childryn pat dame grace kissip ben so acceptable to pe kyng of kyngges pat he makep hem gentil

- folk \& wol be callid here fader. Sik not poow pou were born nakid of sibreden of wordli princes wilis pou art son to sich an emperour \& coseyn vn to seyntes. Falle not fro pat fairehed pou toke in pi baptim \& pou maist lawfulli cleyme heuene for heritage. Pou tellist pat pin beginnynge was of pore reputacion: studie to haue a glorous $181^{\mathrm{b}} 10$ ende. // Affter pe frute is pat is lengest abiden. is a tree demed good or badde.

II. ADUERSITE: I ham komen of a pore nest.

II. RESOUN : So is pe most part of men. Pe nedip to be a schamed pou ast so faire a felawschepe. Neuerpeles pus seith pe philosophur

15 Plato. pat per is no kyng but he kam of seruauntes neper no seruaunt but he kam of kynges. Was not Sauzel of low degre pat wente (to) seken his faderis assis? Kepte not Dauid his faderes schep? \& 3 it pe prophit Samuel ennoyntede hym bope kynges to regne vp on Israel. De moder of our sauyour whas a pore mannes wif sche leide 20 here sone in a crasche in stede of a cradel. In non hyze halle but in a simple howsel was pat babe founden. Feyre maiden where were pe curteynes of pi bed? Dou wantede riche clopes to leize pi child jnne. O. swete Iesu pi most pore natiuite schul descounfed oure prouzde hertes. wenne we be $n$ a schamed of oure pore progeny. Alwey fy on pride.

16. $M S$. so.

24. MS. oure superscript with caret between of and pore. 
exempla posuımus quibus iam irı altıus non possit unum restat non imperio aut regno sed suapte alıa quadam maiestate memorabile Ventıdius bassus esculanus matre humil patre ignoto capta patna lam pubes in triumpho Cneı Pompen Strabonis qui pompeil magni genitor fuit inter captivos alıos

5 ductus Idem postea variante fortuna dux populı Romanı contra Parthorum regem et antıqua potentia et recentı victoria insolentem felicissimo pugnavit eventu et filıo regis interfecto cesisque hostium legionibus quod ad eum diem nullı romanorum ducum fata promiserant insignem illam romanorum stragem et Crassorum mortem magnificentissime ultus ipsum in quo victus alenos currus ornaverat ac carcerem vinctus intraverat victor ac triumphans capitolium propris curribus honestavit et Romanum carcerem acie captivorum hostium implevit Et quo gratius spectaculum esset mirabiliorque victoria eodem ipso die parta erat revolutis annis quo clades illa terribilis apud Carras accepta fuerat Quis ambitiosus adeo tamque avidus regni est ut non hanc gloriam sine regno quam inglorium regnum malit? El quid oro nocunt Ventidio ad felicitatem et ad summum decus quod humiluter natus esset et prima etate fortuna humul usus ac misera? Certe virum esculs despectum Roma suspexit et clans suorum civium nominıbus llud peregrını fuscuin nomen inseruit $\mathrm{He}$ sunt ad ascensum scale hi virtutum gradus

20 quibus non ad glonam modo altrovemque fortunam nitendo sperando vigilando sed ad celum usque pervenias Proinde et tu natus humiliter ut conscendas enitere primum et ulimum virtutis in vestigio pedem figens nec declinans alıcubi nec subsistens a. Dolor Humile principium fuit II Ratio Illud preterint que sequuntur cogita $\mathrm{Nec}$ me latet ut primus et ultımus vite dies 25 quibusdam visı sunt humane conditionis statum maxime moderar sive at ipsi dicunt contınere De ultımo nempe consensenm de primo autem non ita Et si enim ut ipsi volunt plurimum intersit quibus auspicus inchoetur Et si cum his sentıens Satyricus ubi de ipso loquitur Ventıdıo ita scripserit Discas enim que sydera te excipiant modo primos incipientem edere vagitus so et adhuc a matre rubentem Nos tamen ista respuimus et hec auspicia et hanc tantam syderum vim negamus conditon almo syderum omnia relınquentes a quo creatum nullum penitus ab hoc virtutis et felicitatis et glorie

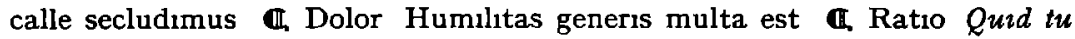
autem? Multam ne superbiam esse malles? Aut quid hinc tibi nunc deesse s5 sentis nisi ne fumosis imaginıbus atrium truncisque statuis bustumque famile semesis plenum titulis spectaculo pretereuntıbus tibı insanie sit qua in trivis de his quos non noveris elato supercilio fabuleris? II. Dolor Ignobilis natus sum $\mathbb{C}$. Ratio Ignobilem non nasci tantum sed et vivere quibusdam felıcitas visa est An in Tusculano saltem a Cicerone positum non

40 legistı illud potentıssimı regis anapestum qui laudat senem et fortunatum esse dicit quod inglorius sit atque ignobilis ad supremum diem perventurus

\section{a DE OBSCENA ORIGINE}

\section{DIALOGUS VI}

II Dolor Ongo non tantum humils sed obscena est II Ratio Vera et sum- 
THE TWO TEXTS PARALLEL

I OF BIRTHE IN LECCHERIE

(1) ADUERSITE: I was juel born for ouzte of matrimonye.

2. Aduersite: capital illuminated. 
lor. Male natus sum. (I. Ratio. Qui bene vivit bene nascitur: bene moritur. At qui male vixerit bene natus esse non potest. Nam quid refert quam fulgido tramite cecus incesserit: aut quid refert unde venias: si in miseriam et in culpam venis? $\mathbb{I I}$, Dolor. In peccato genitus sum. $\mathbb{0}$. Ratio. Deflet hoc quidem 5 ille vir maximus. Et profecto nemo non in peccato nascitur. Cavete autem graviora superaddere: quamquam ne his quoque purgatio sua desit: sed prima illa deformitas in ipso sepe vite limine sacris undis abluitur niveusque animam candor subit. II Dolor. Male me parentes genuere. If Ratio. Quid ad te quisquis male genuerit: tu bene genitus fuisti nisi alieno flagitio tuum

10 iungis. II. Dolor. Fede pudet originis. II. Ratio. Iam quod alieno tumescitis non miror: et alieno simul erubescitis: Et omnino ubique potius quam in vobis et bona et mala vestra reponitis: que alibi tamen quam in vobis esse non possunt. Quod nisi pudendum ipse aliquid penitendum ve egeris: quod tuum crimen: aut quis pudor impudicus pater? tu modo ne paterni dedecoris

15 hereditatem adeas cave: atque illi dissimillimus hac in parte fieri stude. Qui te ignarum genuit: invito tibi suas maculas impressisse non potuit. In te sit et ex te prodeat necesse est unde obscurus aut clarus fias. II. Dolor. Inhonestis parentibus in lucem veni. O. Ratio. Omnis parens honestus filio videri debet: sed non ut verendus: sic sequendus: omnis filio parens: Est ubi deseruisse

20 consilium sit. Eia igitur in diversum abi: si verus est parens deseri volet: seque non suum vitium amari optabit. Unus hic inventus est modus: quo parentum nomen premere et calcare gloriosum filiis ac decorum sit vivendo aliter: castius scilicet ac sanctius. De parentibus inhonestis lingua filii taceat dissimilitudo vite: morum: actuum non taceat. Pulchra laus filii: cui a tergo dicitur: O quantum sene suo modestior adolescens: Contraque nulla gravior senilis nota lascivie: quam admota illi pudicitia iuvenilis: Equidem si parentum gloria filiis male viventibus onerosa est: quanto fasce verecundie filiorum laus patrum male viventium premit infamiam. O. Dolor. Damnata de venere procreatus sum. II. Ratio. Atqui malle debes impudici patris honestus filius

esse et dici : quam honesti impudicus. In omni enim seu laude seu vituperatione illa precipue estimanda sunt que cuiusque sunt propria. De alieno nemo iuste reprehenditur seu laudatur: Et si ut dixi vestrum quicquid id est: conspectius fiat suo contrario admotum. Ceterum ut cuiusque propria laus aut infamia est: sic laudis aut infamie propria causa sit oportet. Neque vero ut unius gladio alter perit: utque unius flammis res alterius uritur: sic unius culpa etiam fama perit alterius: eo quod animi bona solidiora sunt quam corporis aut fortune: ut invito nequeant possessore violari. If Dolor. Contra fas contraque leges genitus sum. (I. Ratio. Nil tu contra leges sed parentes tui egerunt: tu secundum leges age omnia. In hoc quidem nullum penitus tuum crimen fuit:

40 de ortu tuo alii tu de moribus tuis rationem reddes. Et quamvis odio vage libidinis in immerentes filios ultio legum civilium extendatur: deus tamen quenquam suis finibus metitur: nec filii iniquitatem patri imputat: nec filio patris. Ipsam quoque philosophiam iudicare aliter solitam: quam leges ab ipsis philosophis accepisti. Legibus ergo oppressus divino simul ac philosophico iudicio relevatus: habes animum unde soleris: Neque enim tibi ut privati patrimonii sic publice virtutis hereditas interdicta est. Illa enim institutis hominum: hec meritis datur: et antequam nascereris: ut nil glorie: sic profecto nihil infamie 
I. RESOUN : Lefe wel \& dize wel. \& panne schal pi birpe. be to pe no preiudice. Azenward 3 if pou dize in dedli synne $\&$ pou come of seyntes hit schulde not helpen pe. What profetid it Esaw pat was reproued of god for his juel leuynge. pat Isaak. his fader was a

- seynte. or what noizede it Abraham pat his fader Thare dede honour aliene goddes? In ech preisynge in eche blamynge! propere dedes ben to be charched. For aliene vertu. for aliene crime is non man iustli preisid ne lakkid.

II. ADUERSITE: I was vnlawfulli goten.

182 10 UI. RESOUN: Nowt pou but fader \& $/ /$ moder wrougt a 3 en pe lawe. Be pou not pe heiere in vnlawful leuyng. Enforce pe in pis perti to be vnlik to hem of pi conuersacioun \& nouzt how pou ware goten. At domes day schalt pou zeue a countes. More ouere pow pe lawe reuerently faueringe pe sacrement of wedlok ponysch on diuerse maneres children vnborn in mulori. he pat is endeles wisdam hath zeuen pis decre. pat pe sone schal not bere pe wickidnes of pe fader. of poow pe comen lawe inhibete pe to take holy orderes. in holi wryt is non obstacle pen pouz may be an holy lyuere. Statutes also suffre not pat pou be a lawful heire of erpeli possessioun: but

20 lefe pou vertuosly \& pe herytage of heuene schal not to be be entirdyte.

II ADUERSITE: I was gotyn in leccherye.

T. RESOUN: As it seid be fore. per of art pou not to wyte. Pou hast per by occasioun of mekenes not of heuynesse. Be vertu ne pe swete smel of pe rose is neuere pe lesse. pat his moder is a porn. Vse honeste in lyuyng \& pou mayt haue no betere besom to swepe a wey pe motes of infames birpe.

10. In lower margin of $781^{\circ}$ the catchword moder.

16. decre: illegible $\mathrm{c}$ corrected by superscript $\mathrm{c}$.

23. to superscript with caret between not and wyte. 
meruisti. If Dolor. Origo illicita et incesta est. II. Ratio. Quid de incestu: quidve de adulterio nasci queat: indicio sunt Romulus et Alcides. Perses Macedonie: Jugurtha Numidie rex fuit: uterque legitimis fratribus regno exclusis: malo quidem more pessimisque artibus sed exclusis tamen Alexan5 der Macedo Philippi dictus: cuius vere sit creditus audisti. Denique Philippum extremo vite Alexandrum non suum filium predicare solitum: Idque sibi ultro confessam Olympiadem: hancque ob causam repudio dimissam scriptores rerum prodidere. Constantinus ipse ex concubina genitus licet insigni pre legitimis fratribus ad imperium venit. Adderem his Arturum

10 regem nisi quod historiis miscere fabulas nihil est aliud quam mendacio veri fidem imminuere. Ad summam vero: non est quod te deiciat origo: Undecumque ortos virtus extulerit satis est glorie. a. Dolor. Male natus sum. (II Ratio. bene vive: bene morere: qualiter natus sis: nec tuum est: nec meminisse quidem potes: nec magnopere inquiras: quod ad te non pertinet: nisi forte ut humilior mitiorque: non ut mestior sis. II. Dolor. Turpiter natus sum. II Ratio. Morum candor et claritas vite: non maculas modo: sed memoriam omnem fede originis delebunt. Hoc remedium dum licet arripe: aliud mihi crede nullum est. II. Dolor. Pudet infamium parentum. II. Ratio. Pone hunc pudorem: Unus omnium pater deus: una omnium mater terra.

\section{DE SERVITUTE}

\section{DIALOGUS VII}

(1. Dolor. Servus in hanc vitam intravi. II Ratio. Ne doleas: liber egrediere velis modo: sicut multi qui ex adverso intrarunt liberi: sevvi exibunt. a. Dolor. Serviliter natus sum. II. Ratio. Liberaliter vive: meliore tui parte liberum esse nil prohibet: una est peccati servitus gravissima: sed que premere nescit invitos: Illam excute liber evis. II. Dolor. Servum fieri voluit fortuna. OI. Ratio. Potest velle contrarium: Et si moribus suis utitur: scis quid speres. Nosti monstrum illud: nosti ludos et prestygia: non liber modo: sed domini tui dominus fieri potes: quamquam quid velit aut quid nolit: nihil ad rem: ut so sit inexorabilis: quod interdum est: nullum illa tamen in animum ius habet. In omni autem adversus illam certamine ab illius hoste poscendum auxilium. Sepe quem fortuna servum: liberum virtus fecit. I. Dolor. Servitio premor gravi. đI. Ratio. Jugum qui fert volens leve efficit. Ostendam tibi lenimen unicum ac peculium immortale: dominique tui quamvis potentis arbitrio exemplum: quod te liberum, atque ipso domino ditiorem faciet: Sapientie studio incumbe: Illa te in libertatem asseret. Dictum Catonis est a Cicerone firmatum. Solus sapiens liber est: ea scilicet libertate qua certior nulla est. I. Dolor. Sub durissimis dominis vitam traho. II Ratio. Nulla re melius quam fide et obsequio mollientur: et fortassis adeo ut quod multis accidit: inde tibi so ventura sit libertas: unde te servum luges: forsan et aliunde. Hunc siquidem temporalis dominus liberat: hunc eternus. Scis quanto periculo Malchus minas heri persequentis evaserit: sed evasit tamen. Interim de domino sic cogita: hic te nutrit tuique curam omnem in se transtulit: Cum libertate sollicitudinem amisisse: quid nisi utile damnum voces? Multis serva libertas: multis est libera servitus. Non tam grave iugum hominum quam curarum 
ADUERSITE: I ham boonde. sich is myn hap.

II. RESOUN: Be greuest bondage pat may be is to be sugget to synne. Ley not pi schuldres vnder pe zok of malice. $\mathcal{E}$ penne is pi

- better pat is pi souzle free. Aristotele wrytip. pat sum men ben seruaundes be lawe. \& sum men be kynde. A naturel seruaund is he wos souzle is vnable to haue pe zifte of discrecioun. for siche men $182^{\mathrm{b}}$ (ben) vn apt to bere pe zerde of gouernaunce. A legale // seruaunt is he whom fortune or self wille hap feterid with pe bond of bondage.

10 Be pou panne besi in pi gostli chaumbre of wisdom \& vertu to make a tresory. So may pou dignify pi self to be pi lordes lord 3 if his inwit be bareyne $\&$ naked of resoun. Certis dame fortune failip power to spoile vertu of his gentilnes.

a. ADUERSITE: I was bore bonde.

II. RESOUN: Serue truly pi god \& pou schalt dize a fre man. for wete pou pis wele pat many fre born men with displesaunce of her makere hauen be trappid hem self in endeles praldam. I rede ones

2. Aduersite: Capital illuminated.

8. $M S$. siche men vn apt.

16. MS. pis in margin with caret between pou and wele. 
est: qui hoc excusserit: illud ferat equanimis. Huic tu servus, huic uni es deditus: immo hic tibi: hic tuus est dominus: immo procurator est tuus. Non habebis honores equidem, nec labores publicos: non simultatum studiis: non forensibus procellis: et consiliorum volubilitate rotaberis: non navigii 6 tarditas: non agri sterilitas aut annone caritas te torquebit. Has molestias domino tuo linquens: sepe illo dormies vigilante. $\mathbb{\mathbb { I }}$ Dolor. Difficilis et imperiosus est dominus. $\mathbb{a}$ Ratio. Non sine causa illi in sortem obvenisse in animo tuo pone. Quicquid igitur iustum iubet: deum ipsum iubere credito. Sin iniustum aliquid: maioris domini meminisse conveniet: qui ut te ad honesta quamvis difficilia servum patitur: sic ad inhonesta vult liberum. Sic intelligo quod gloriosorum terre vereque fidei principum: alter servos dominis carnalibus obedire per omnia: alter vero subditos esse in omni timore dominis precipit: Illud adiiciens: ut hoc non tantum bonis et modestis exhibeant: sed etiam discolis: neque enim de domino iudicare servum decet: sed mores eius qualescunque perferre. Quo enim immitior dominus: eo clarior patientia servi est. Et hec est gratia cuius apud horum alterum sit mentio: nec tamen ut mores pati: sic et imperia exequi semper oportet. Sunt enim que iustissime recusentur: si imperio domini superioris adversa sint: Cui si conferatur hic tuus dominus: non dominus sed conservus habebitur. Sic ergo per omnia dominis

20 obediant servi: si iusta precipiunt: non difficultas retrahat: non labor: non obsequia vel negata premia: vel quod est in rebus amarissimum: irrogata supplicia: In omnibus obediant: modo iniustitia atque inhonestas abfuerit: Alioquin contumacia et libertas: atque ipsum pectus et iugulus iniquis preceptis ac turpibus opponendus est: servandumque memoriter: quod premis-

25 sorum alter ait: qui cum servos obedire per omnia dominis precipisset: addidit: Non ad oculum servientes quasi hominibus placentes: sed in simplicitate cordis timentes dominum. Ex his vides status tui conditio que nam sit: Non totus est servus qui ad indigna imperia cogi nequit. II Dolor. Superbo domino servio. II Ratio. Quid scis an ille superiori domino serviat?

30 Forsan uxori: forsan meretricule: forsan his ipsis quibus imperat: Quot suorum servorum servos undique cernimus? Postremo que durissima omnium est servitus: forsan et ipse sibi: hoc est vitiis et passionibus ac violentis affectibus suis servit? Quid vis dicam? Pauci in veritate sunt liberi : et si qui sunt: eo illis laboriosior vita est quo altior. Multo enim citius multoque facilius

35 fidelis servi quam iusti regis implentur officia. Diocletiani iam privati et de preterito iudicantis: et experientia edocti dictum memorabile est. Nihil difficilius quam bene imperare: Propter quod videri potest ipsum quidem imperium dimisisse. Tu igitur sortem tuam letus amplectere: fuscam fateor atque humilem: sed facilem ac tranquillam: nisi forte feliciorem reris in specta-

40 culo anhelantem quam in cubiculo quiescentem. II Dolor. In servitium mea me sors impulit. II Ratio. Libens facito quod oportet: Est et illud quoque notissimum: ac necessitatibus humanis aptissimum consilium. Cupias quodcunque necesse est: sic vim ipsam necessitatis eluseris. Fer fortune sarcinam patienter: quam quidam etiam sponte subiere. Utque alios servitio liberarent: 45 sibi servitium delegere. In quibus est clarissimum Paulini nomen Nolani

3. Ven. simulatum.

44. Ven. liberaret. 
in Job. pat per is no ping in erpe don with ouzten cause. Dou wost pis wel pat he pat suffrede pe to be born bonde myghte haue made pe an emperour. but perchaunce $z^{\text {if }}$ pou drank of pe chalis of reuerence. pi binyn is so feble it wolde make pe toty. Two pinges per ben pin ere to pe preching of seynt Petre: Be ze seruauntes sogetes to 3 our souereynes. 3 e poow pei be $n$ trewauntes. in leful pinges $\&$ lawfull. for 3 if it happede-pat Crist forbede-pat thi lord comaundede owt pat is to Crist contrarie pou art asoiled in pat forme his

10 obediense. for poow he be pi lord here? as anemptis god he is but with pe a seruaunt.

II. ADUERSITE: I suppose neuere in pis lizf be opur but a seruaunt.

(II. RESOUN : bou haddest wele in pis lizf: for after pis lizf is non sekur seruice. Who so seruep god best in pis valei of teres: lord in pi holi mounteyn he schal sitten heizest. For pe to serue! is to regne. In erthe a knaue in heuene a kyng. pis is a gloriouzs chaunge. 3it take hede. here hast pou non worschepe but filynge labourus. But wat pou art discharched of foreyn tempestis! // Pouz schalt not be 2o hurled nopur sent affter to gret conseilles nepur to sessiounes. How so euere pe world waggeth pou mayt not falle fer. Who so sittip on pe bare grounde pow his sete be symple he restip more safly pan 3 if he sat on hyze towres.

II. ADUERSITE: Pe charche ob bondage weyith heuy vp on my nekke.

(1. RESOUN : Frowardnesse of wille fond neuer zit lizt birpen. and what is more folie pan whanne a lode is greuouzs to leye more to? Di grucching weihip more pan doth pi seruyse. And how mayt pou pleyne pe pat pou art heuy charched sipthen pou gost half void? Doow so pi bodi fele bondache. pi souzl may perse heuene $\&$ haue contemplacion of heuene delices. Pe myghtes of pi souzle may walke a mong pe ierarchies. Now to heuene now to erpe maist pou sende pi pouztes as pe good likip. $\mathrm{Per}$ is non erthely lord may priue pe of pis fraunchis. De wise clerk Plato was taken of pefes. sold. \& so mad pral. \& lowtede to pe biddyngges of a wicked tyraunt. But Jerom recordep. pat for he was a philosophore. he was betere pan his biz-

4-5. to expuncted in MS. between ben and to.

30. MS. fele liberte followed in margin by $\cdot \mathrm{i} \cdot$ bondache apparently added later by the same scribe in smaller handwriting. 
presulis cuius spontanee servitutis exitus fellx ut debuit fuit $Q u$ dam parvo se precio vendidere ut servi effect suos dominos peccat 2 vinculis absolverent atque ad veram reducerent libertatem in quibus Serapion quidam egyptius heremicola noblitatus est $\mathrm{Hec}$ tibi magis exempla profuerınt quam lamenta

5 Experire et tu tale alıquid quo vel utilis alter vel faclis tibi saltem servitus tua sit Non id quidem quod non habeas optare sed eo quod habeas bene uti sapientis est Illud ommibus contingit hoc paucis II. Dolor Mortalı domıno mortalıs servio (II Ratıo Immortalı servire incıpe Ille tıbı et libertatem spondet et regnum quamvis et in hoc statu nec honestis artzbus operam dave nec sperare meliora sit vetutum Et Terentius servus fuit et didicit haud servilı quidem ingenio et comedias scripsit haud servilı stılo quo et Iibertatem et inter poetarum duces meruit locum Quomodo ergo virtutem solidum anime bonum servitus impediet que nec adventitia studia nec externam gloriam impedire potest' Plato ipse in servitium delatus tamen ut scriptum est quia philosophus maior emente se luit Generosa professio que maiorem domino servum facit Et est haud dubie servus eruditus eo maior indocto domino quo fortuna qualibet maior est animus et in libero corpore serva mens habitat et in servo libera Obstare servitus potest fon actibus non animi Cuna servum respuit at non virtus non industria non fides Titon

20 Ciceronis servus fuit sed his artibus libertatem adeptus elegantem de patron 10cis librum posteris liquit Non potest servus imperator exercitus aut Senator esse at philosophus at orator at vir bonus potest Aliquando etiam discusso servitio imperator et rex quoque Neque ad regnum modo et imperium ab hoc gradu pervenisse aliquos novimus sed ad celum ipsum

25 Non potest servus militare hominı deo potest elusque mlitie stipendium est regnare Del servus rex est omnium socius angelorum horror demonum Dei autem servus et servus hominis esse potest atque ita celestı felicitati

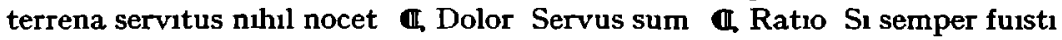
consuetudo luctum leniat $S_{1}$ minus spera posse te iterum non esse quod 30 quandoque non fuerıs ar. Dolor Servus sum a, Ratio Si speras maln finem minuat spes dolovem $S_{\imath}$ desperas patientia neque malum malo cumules neque te angas supervacue screns volensque que totrus humane dementre summa est Sed certe nihil est desperandum si cuncta defuerint mors aderit que te invito domino dissolvat ac liberet 
ere. A gentil professioun pat made pe seruaunt more penne his lord. Kyng Nabugodonosor. slepynge saw a wonderful visioun. But it was so hard lokked in pe whicch of forgetynge pat he kowde not telle wakyng what he hadde seen. Alle pe sagis of Babiloun kowde

5 no keies fynde pis visioun to schewe. til Daniel vndede hit $\mathcal{F}^{\circ}$ pe misteries per of. pat to kyng was captif. Lo what fredam // was zeuen to pe seruaunt of god to vnloke hid pouztes. He vnbond his byndere of his heuy stodie. And wolt pou haue on schort word: Bonde body \& free souzle a corden wel jnow to gedere. but bonde 10 souzle \& free body pryuen neuer wele.

(I. ADUERSITE: De lord pat I serue is to me a tiraunt.

(1. RESOUN: 3 if pou suppose to wynne ouzt of his daunger. let hope be pi mynstrelle. \& 3 if pou be in dispeir. hepe not sorwe vp sorwe: on sorwe suffices. But certes in dispeir per pe not be. deth

15 hiep faste. \& wil pi lord nyl pi lord he wole deliuere pe out of his seruise.

II ADUERSITE: Vnder an hard lord \& a steerne. lede I my lizf. व. RESOUN: Dere is no schortere weyze to soften his dures: pen with a buxum herte to do hym feithful seruise. \& perchance it may 20 be tide to pe pat hap don to manye. pat porw pi true seruise: pou schalt be weddit to liberte. Forzete pou not pis olde prouerbe: Alle is wel pat endep wel. \& rule per affter. Often hast pou herd pat Joseph was twies sold. first to Hismalitis $\&$ sithen in to Egipt. how obedient he was to god $\&$ to Putiphar his lord his souereyne. for his goodnesse hadde to him sich afiaunce pat he ordeynede him gouernour of his houzshold. Affter pis poruz a fals tale of his fals lady. be cause pat he nolde be fals to his maister he was falsly en presound. but trupe pat may not be slayn. poow it be beten: brak at pe laste his feteres. \& losede him of his praldom \& made he was a gret prinse. Be same god pat wrouzte pis maistries in Joseph: kan zeue pe sich a grace in pi lordes sizt? pat porw pi good be // ryng pou schalt no lengere kepe pe cloistre of bondache.

2. but is written twice in MS.

11. a expuncted in MS. after is.

21. holde in MS. with h expuncted. 


\section{DE PAUPERTATE}

\section{DIALOGUS VIII}

II. Dolor. Paupertate pressus sum: assurgere nequeo. II. Ratio. Sepe quidem paupertas modestiam persuasit reluctanti animo: quodque nequaquam philo5 sophia temptaverat: hec implevit. II Dolor. Paupertas meum limen obsidet. I. Ratio. Non obsidet sed custodit: neque hoc illi novum aut insolitum: ut que urbem Romam multis olim seculis custodivit. Inter tentoria equidem paupertatis sobrie atque sollicite: luxus iners: sopor marcidus ac vitia languida et enervata non subeunt. $\mathbb{I}$ Dolor. Domum meam paupertas invasit: $\mathbb{\mathbb { I }}$. Ratio.

10 Ultro illi ut occurras consulto. Venientem leto animo bipatentibus valvis excipiens atque amplectens: prima enim fronte rigida ac subtristis: nec immerito viatori ac viro armato exequata: eo quod celer minaxque sit adventus eius: At cum in familiaritatem admissa fuerit et minime sumptuosa et secura ac facilis hospes erit. $\mathbb{a r}$ Dolor. Foribus meis paupertas insultat. $\mathbb{a}$. Ratio. Aperi

15 ocius antequam vectes subita vi confringat: atque ostiis vulsis a cardine victrix introeat: ut enim resistentibus permolesta: sic cedentibus periucunda est. II Dolor. Dornum meam paupertas irrupit. đI. Ratio. Adversus fures et peiores furibus voluptates pervigil excubitrix: Adversus vulgi morsus et insulsa iudicia atque avaritie seu prodigalitatis infamiam: que raro alibi quam locuple-

20 tum sedet in limine. Ab his malis nullo melius ingenio custodivi potuit domus tua quam illam custodivet paupertas. Ut dives et si largus sit si quid tamen sibi reservat: avarus vulgo dici solet: sic pauper cupidus quoque largus habebitur. Invidet opibus vicinia: pauperiem miseratur. Illas cupit ac vituperat: hanc horret et laudat. II Dolor. Domum meam occupat paupertas. C. Ratio.

25 Iam nullus tibi superbie locus evit: nec invidie: nec damnis insignibus: nec damnorum metui: nec suspitionibus mille: nec insidiis: nec nausee: nec podagre divitum hospitibus: Quibus exclusis habitatura latius tecum quies et tranquillitas et virtus: Cui eo plus loci erit: quo fortune minus. $\mathbb{I}$. Dolor. Lares meos dura subiit paupertas. đI. Ratio. Quid queraris scio: Mollius divitie so subiissent: sed paupertas tutius. Nulle autem opes sunt: quibus non sit anteponenda securitas. Cum ad felicitatem enim omnia quecumque agunt cupiuntve homines disponantur: esse illa sine opibus quidem potest: sine securitate non potest. (1. Dolor. Paupertate importuna diu premor. II. Ratio. Ut nihil importabile diu fertur: sic nihil breve difficile. Sed hoc dicis gravius: Excute

35 autem illam cum divitiis an plus auro tribuis quam virtuti? An et hoc in paradoxis stoicis non legisti: quod solus sapiens dives est: $A$ legisti forsitan sed sprevisti? quod plerique faciunt legentes: ut fabulentur ornatius: non ut melius vivant: nihil ad honestatem: omnia ad scientiam atque eloquentiam referentes: quo nihil est vanius.

15. Ven. ostii. 
ADUERSITE: I ham oppressid with pouerte.

II RESOUN: Refreyning of pi lustes calles pou oppressing. Nouzt so but it kepip pi place fro mochers and peues. ze. \& fro fleschli 5 lustes. pat ben meche werre. Glotenye $\&$ slauzpe ben a ferd of his loke for he hath often vntid hem $\&$ letted hem of her reste. Doow hym seme heuy chered $\mathcal{E}$ sterne: at pe firste komyng. were pou a queynted a while with hym. pou schuldest fynde hym. an hesi gest. He is no ping suptuouzs. he lokep nepur to be fed with partrik ne 10 with fesaund. confecciones \& swete wynes he knowep nepur nopur. Dou maist make hym a feste with a fewe ferpinges. Bow pride loue not his felowschepe. 3 it enuye spekep of hym none ille. Go were pou wolt. 3 if pouerte kepe pin hows pou derst not be a gast. ne haue suspescion to pin neyzebour. pat pei wole breke pi walles $\mathcal{E}$ bere a wey pyn huches. 3if pou walke be pe kuntre \& pouert go with pe pou schalt kun demen pat ilke straunge man pat pou metist. is a robere. Haue pou (no) more felouzschepe but him an pi staf: pou maist go more sekerly pan a gilt spore with his fyne hors. Many a likerous man hap pouerte with chastesinge tawt to kepe temperaunce pat philosophie with fayr speche myghte neuere brynge hem to. $\&$ how scholde pouerte priste pe doun. sythen euere pe porere pou art: pe lesse art pou charched. Also litil as pei may wel lest: pilgrimes trussen with hem. Pe naked man komynly ouer rennep pe cloped. Haue mynde pou art here a straunger \& hast fer to go. // Men loue 25 not to wrastele clothed for pe swan. Bei enemye may werst holde haue of pe wanne pou gost alderest bare. To pleyne pe pat pou berest heuye: wanne pou berist litil: is a wrong formed pleynt.

II. ADUERSITE: It is an hard ping to be pore.

II. RESOUN: Pere is non bed soft to a seke man. Were pin appetit so helid of couetise pou schuldist pinke pouerte a restful kouzche. To be riche is solempne! but to be pore is more sekur. Now bou knowest pis wel pat alle men kyndely desiren felicite. May not felicite be had with ouzten worldes welpe? 3 is. but were sekirnes is wane:

2. Aduersite: Capital illuminated.

4. mochers. MS: mocherers.

16. Before ilke $a \mathrm{p}$ is faintly legible as if it had been pilke.

17. $M S$. haue pou more.

32. MS. not in margin with caret between may and felicite. 


\title{
BOETHIUS
}

\section{DE CONSOLATIONE PHILOSOPHIAE}

\author{
LIBER II, PROSA II
}

Vellem autem pauca tecum fortunae ipsius verbis agitare. Tu igitur an ius 5 postulet, animadverte. 'Quid tu homo ream me cotidianis agis querelis? Quam tibi fecimus iniuriam? Quae tua tibi detraximus bona? Quovis iudice de opum dignitatumque mecum possessione contende. Et si cuiusquam mortalium proprium quid horum esse monstraveris, ego iam tua fuisse quae repetis, sponte concedam. Cum te matris utero natura produxit, nudum rebus

10 omnibus inopemque suscepi, meis opibus jovi et quod te nunc inpatientem nostri facit, favore prona indulgentius educavi, omnium quae mei iuris sunt affluentia et splendore circumdedi. Nunc mihi retrahere manum libet. Habes gratiam velut usus alienis, non habes ius quevelae tamquam prorsus tua perdideris. Quid igitur ingemiscis? Nulla tibi a nobis est allata violentia. Opes honores ceteraque

15 talium mei sunt iuris. Dominam famulae cognoscunt; mecum veniunt, me abeunte discedunt. Audacter adfirmem, si tua forent quae amissa conquereris nullo modo perdidisses. An ego sola meum ius exercere prohibebor? Licet caelo proferre lucidos dies eosdemque tenebrosis noctibus condere. Licet anno terrae vultum nunc floribus frugibusque redimire, nunc nimbis frigoribusque confun-

20 deve. Ius est mari nunc strato aequore blandiri, nunc procellis ac fluctibus inhorrescere. Nos ad constantiam nostris moribus alienam inexpleta hominum cupiditas alligabit? Haec nostra vis est, hunc continuum ludum ludimus; rotam volubili orbe versamus, infima summis summa infimis mutare gaudemus. Ascende si placet, sed ea lege ne utique cum ludicri mei ratio poscet, descendere iniuriam putes. An tu mores ignorabas meos?' (etc.)

\section{D.R.U.F. continued :}

\section{a. DE DAMNO PASSO}

\section{DIALOGUS IX}

(II) Dolor. Opes cunctas trux fortuna preripuit. $\mathbb{\mathbb { U }}$ Ratio. Non tibi fecit iniuriam: suum tulit: sed vetus et nota hec ingratitudo est: dati immemores: meministis ablati. Itaque vare ac tepentes gratie: crebre ac jervide sunt quevele. $\mathbf{0}$. Dolor. Fortuna ferox: vite quoque necessaria subtrahit. (I. Ratio. Necessaria subtrahere potest nemo: quandoquidem vere necessarium est nihil sine quo bene vivitur. Dico autem bene: non voluptuose: non insolenter aut splendide: sed prudenter: sed sobrie: sed honeste. In quibus nullum sibi ius esse quamvis insolens fortuna fatebitur. Et certe cum nec toto quod est usquam auro: neque omni gemmarum pompa atque omnigenum rerum copia: cupiditas expleatur: paucis admodum: et si desint: levi lingue vel manus artificio comparandis tollitur aut lenitur necessitas naturalis: sic virtuti modicum: vitio nil sufficit. $\mathbb{0}$. Dolor. Victum vestitumque necessarium avara sors negat. II. Ratio. Aliunde petendum. Virtus liberalior quam fortuna est: nihil negat 
pere is non verrei blisse founden: Wanne opinions risen of werres $\mathcal{E}$ bateilles panne dreden lordes. perelles of pe see feren grete marchauntes. \& whanne cornes tymen not? wepith pe frangeleyn. Wanne alle pese wanten nyghtis reste! panne liggeth pe pore grom in his herden

5 shetis \& slepith ful sauerly. A. haue pou litil katel: litil kare. pis olde sawe is soth.

II ADUERSITE: Fortune hath fro me taken pe riches pat I hadde.

I. RESOUN: What iniurye hath he don? Sche hath taken but her 10 owne. Lent ping is not zeuen. Dignite $\&$ richees hap non man here but of borwyng. Whanne nature broughte pe forp naked in to pis world: dame Fortune lent pe kouerynge. Sche norschede the $\&$ heder too hath fownden pe of here owne koueres. Sche hath plesid pe longe with affluens of godes. $\&$ now here lust sum del to with drawe here hand. Sche hap not raft pe all. zit for old felouzschep (and) frensche-

15. MS. felouzschep frenschepe. 
nisi quod et permissum noceat et negatum prosit: nihil eripit nisi quod habuisse damnosum amisisse utile sit: Non differt: non imperat: non retrahit manum: non rugat frontem: non attollit supercilium: nullum despicit: nullum destituit: nullum fallit: non sevit: non irascitur: non mutatur: una 5 semper et ubique est: nisi quod magis magisque degustata dulcior in dies: et propius conspecta fit pulchrior. Ut sis igitur verus dives: ab hac poste non te fastidiet nec repellet: quamvis exerceat: difficiles habet aditus primos: cetera prona: iucunda: facilia. Semel vero ubi ad illam perveneris : non senties paupertatem. II Dolor. Spoliavit me bonis meis omnibus fortuna. I. Ratio. Fallit te opinio: malum commune mortalium. Nam profecto non bonis: et ut bona permiserim: non tuis: sed que tua forsitan vulgi more credideras. Mirorque si nondum intelligis aliena. $\mathbb{T}$. Dolor. Fortuna me nudum liquit atque inopem. (I. Ratio. Virtus te vestiet: ni respuis ac ditabit: nisi forte pluris aurum et purpuram quam decorum generose mentis habitum facis. Quod si faceres:

15 tunc vere inopem nudumque te dicerem. II. Dolor. Contra fortune impetum et inopie molestias nullo satis artificio tutus sum. G. Ratio. Quid miraris: artificium tuum omne et arma quibus te tueri cogitas in manibus hostis sunt. Illa capulum tenet: in te cuspis obversa est. Si consilium queris : his omissis age aliud: artibusque illis ingenium applica in quibus fortuna ius non habet. Non divitiis virtus: sed virtute divitie queruntur. Virtus una contra fortunam omnem contraque pauperiem ars optima. Legisti ut ad littus Rhodium naufragio eiectus Aristippus: et ipse nudus inopsque rerum omnium: quas dare potest fortuna vel auferre: dum locorum novitate captus: ut fit: oculosque circumferens: forte illos in quasdam descriptiones geometricas defixisset: exclamans consolatus est comites: et bono animo iussit esse: neque enim desertis locis applicuisse: cernere se hominum vestigia: Inde oppidum introgressus ad gymnasium litterarum recto calle contendit: Atque ibi philosophicis disputationibus admirationem primo: dehinc amicitias optimatum et munera meruit: quibus non tamen sibi sed etiam sociis victum ac vestitum et profectioni necessaria ministraret. Cumque digressuri quererent: quid ille nunciari domi vellet: hoc unum iussit: nunciarent eas opes filiis parandas que naufragio non perirent: quas nec maritima nec urbana nec bellica tempestas eriperet preclare. (II Dolor. Rerum atque animi inops sum. (II Ratio. Primum te expeditum: secundum plane inopem facit et miserum. Sed ut

95 Aristippi consilium: sic et Theophrasti dictum te legisse arbitror: Quid vero lectio sola profuerit et meminisse oportet et in usus tuos lecta convertere. II. Dolor. Domo: familia: necessariis atque ornamentis omnibus spoliatus: quid agam: quo me vertam? $\mathbb{I}$ Ratio. Ad eas opes quibus spoliari nequeas: que te undique comitatum divitem et ornatum prestent: Et quoniam ut 40 video: excitanda memoria est: Theophrasti quod memorabam dictum ad hunc se habet modum: Doctum ex omnibus solum: neque in alienis peregrinum: neque amissis familiaribus et necessariis inopem amicorum: sed in omni civitate esse civem: difficileque fortune sine timore posse despicere casus: At qui non doctrinarum sed felicitatis presidiis putaret se esse vallatum labidis itineribus vadentem: non stabili sed infirma conflictari vita.

9. me/Ven. ne. 
185 pe! sum what hap sche left pe. But it is // pe olde manere of vnkynde folk sone to forzete what is don for hem. but 3 if ouzt displese hem per onne pei penken longe. Pankynges kepen to meche silens. but pleynynges chateren faste.

5 II. ADUERSITE: I haue not offendit. whi fortune schulde with drawe here fauour fro me?

II RESOUN: It semep pat pou knowest not pe condicions of fortune. Whi schulde sche alle one be forfendit for to vse here right? De sonne clopith pe eire on daies in his bemes. on nyghtes he hidip 10 hem $\&$ leuep pe aire nakid. Sum tyme pe mone starith brode. sum tyme it lokith narwe. Now pe wynde is lowd: now is it stille. Pe see ebbith \& flowip \& so many opere. A zens pese mutacions grucche no man for pei ben naturel. $\&$ als kyndeli it is to fortune to be chaunchable. Telle me panne. whi schulde a coueitous herte constreine here to be constaunt? Here proper werkyng is to turne her wheel a bowte. 3 if pou climbe on pis wheel loke affter non opur. Whanne pou komest to pe heizest poynt: pere mayst pou not longe sitte. For whi? It is a zens pe lawe of her gamen. $\mathcal{E}$ zif it happe pat pou falle. kach hope be pe skirt. it is possible to ascende as hize as pou were. While 20 wele $\&$ woo pleyen at pe balle. nepur of hem kan holde longe pe balle stille. but hedur \& pedur it (gop) contynuely. Dus sum men ben ofte doun \& recouere a zen. 3 e sum tyme wen men loken lest after socour: panne is goddis grace ner pan pe bischops dole.

II. ADUERSITE: Fortune hath spoiled me of my goodes.

II. RESOUN : A comen opinioun. pat fals is hap deceyued pe. De affeccions of meche folk // aren so faste fetered in pe panter of auarice pat 3 if a man wante richesses: pei seize he hath no good. But wisdam redeth vs a noper lessoun: $\mathbf{P} e r$ ben pre manere of goodes. goodes of grace. of nature. \& of fortune. De laste hap lest of goodso nesse. $\&$ pe firste ben best. Fro pe may fortune nouzt bere: but pat sche may bringe to pe. Richesse $\&$ dignite ben here two handymaidenes pei komen $\&$ gon with here. but kunnynge $\&$ vertu howen here non seruice. Ding pat may be raft pe a zenes pi wille: was neuere properli pin. but pat is verily pin owne! pat may not be taken

s5 fro pe with ouzten pin assent. Such goodes are vertues. Who so hath non of hem: is not only pore: but a verrey wrecche.

2. MS. 3if superscript between but and ouzt with caret in between.

21. $M S$. hedur \& pedur it contynuely. 
I. Dolor Patrimonium paternum habuı perdıdı quid consılı capiam? II Ratıo Patrimonium paternum duplex Alterum ex rebus pereuntıbus quod fortuna moderatur ex virtutibus et doctrinis alterum quod extra fortune regnum procul in tuto positum ledi nequit Hoc est illud quod in

5 primis amantissimi patres filıs tradunt quod nisı repudietur eos in finem et post finem viteque exıtum exornat possessonbus suis non equevum modo sed vivacius multoque perennius Idque attendens illa nobilis morum et eloquentie et legum parens Athenarum civitas Cum grecarum omnium leges urbium indistincte filios ad prestanda parentibus alımenta compellerent eos solos statuit alı oportere qui liberos erudissent quod hi solı patrimonium certum suis stable relıcturı essent II Dolor Multa mih ad vitam desunt II. Ratro Cur pauca suffrciunt quomodo desint multa non video Sed deesse vite dicatıs quod avaritıe deest Ita fit ut non multa tantum sed omnia vobis desint et que habetrs et que cuptis quod et ulla tangere non audetis et hec assequi non valetıs utrobıque par vel miseria vel egestas $\mathbb{\pi}$. Dolor Nimium pauper dego II. Ratıo Solare anımum comitıbus magnıs et illustribus Valerius Publicola unus e romane libertatis auctoribus Menenius Agrıppa romane sequester pacis unde sepelirentur quia de proprio non erat de publico habuere Paulus Emilius Macedonum regum victor finitorque regn famosissımı et antıquı

20 tam dives glorie tam pecunie inops fuit ut nisi agello tanti viri vendito restituı conıug dos non posset Attılius Regulus Cneus Scipıo Quintius Cincınatus romanı imperı defensores tanta reı familiarıs inopia fuere ut primus in Africa maximas res gerens secundis in Hispania Ille propter villici mortem hic propter filie dotem missionem a senatu petere cogerentur

25 et obtinuissent nisi senatus reipublice consulens optimorum civium succurrisset inopıe Quintıo autem quaterna agn ıugera arantı senatus et populı consensu rebus in extremis summum imperium deferretur $H_{1}$ accedant Curius hortulo dives et Fabricius parvo potens qui oblatas contempsere divitias et nihil preter ferrum dextrasque et anımum habentes ditissimum

30 grecie regem ac potentissimum itahe populum domuere Auro ipsi eque ac ferro inexpugnabiles et invictı Et quid loquimur cives cum et ıpse populus romanus omnis exımie fons atque exemplar historie tamdiu bonus fuent ut dicere ceperam quamdiu pauper fuit At libidinibus probrisque Nero obrutus opes suas metirı ac dinumerare non poterat At Varıus Heliogabalus effeminatissimus turpissimusque homınum at vestr pudor imperu ventris onus dictu fedum et auditu sed pro feda cupiditate mortalium forsitan non sılendum non nisi auro excıpı dignabatur cum non supenorum modo talıum vurorum cenas sed deorum sacra fictılıbus agı solere meminisset $O$ urbs misera ad tam turpes manus fatis lapsa volventibus Sed o aurum avaritie votum 40 ingens $O$ spes ultima et laborum terminus humanorum in quos usus oculorum stupor ac mentium vertebaris Laudarem factum aut certe non arguerem quod errori hominum tam obsceno nulla aptior esset insio s1 ab homine sane mentis id fieret Nunc preclaras optandasque divitias quis negare audeat que si ferro ac scelere peti velint dum sic spretis optimis sic pessi-

45 mis affluunt? $\mathbb{E}$. Dolor Pauperem in laboribus vitam duco $\mathbb{O}$. Ratio Cleantes hauriende aque et rigandis oleribus Plautus sarcinas mole manuarie locare operas urgente inopia coactus est Quantus lle phulosophus hic poeta 
व. ADUERSITE: Me wantip manye pinges necessarie to my leuyng.

đI. RESOUN: How may manye pinges wante: where fewe pinges sufficen? Nede may sone be riche jnow. but couetise seyzeth neuer

5 hoo. Als meche as he wolde haue! as meche him faylith. For pi wille seuer. pat not he pat lest hap! but he pat most coueitep: is most pore. Pe more pou laborist wel here \& hast litil reward: pe more mede is to komen. Manye hap per ben. $\mathrm{pa}(\mathrm{t})$ for desire of heueneli richesses. hauen ioifulli chosen pouerte to peramour \& pat most is

10 of alle. pe emperour of blisse at whos list ertheli kingges ben corowned $\&$ deposed: likidde to leuen pore $\&$ naked to deth. Now feith zeuep no man licens for to suppose. pat per be // any hender path to heuene panne his ensaumple.

(14. ADUERSITE: I ham not so riche as I was wont to bee:

(II. RESOUN: Wel. panne schalt pou lernen to be pe more lowly. Richesse taken neuere here leue be per one. for myse \& mowtes folwen hem euere. Frowardnesse $\&$ falsnes of seruauntes gon with hem. $\&$ (on) pat opur side mekenesse. soburnesse. sekurite $\mathscr{\sigma}$ reste. loue wel pe cumpanye of symple pouerte. Were pouerte $\&$ paciens 20 wonen to gedere: pere is rich pouert. Set be for pin eizen pe lif of holi Job. Wanne he was in his flouzres of wordli auer his handes were euere open to pe dedes of mercy. Widwes $\&$ fader(l)es childrin fownden hym a freend. pe hungri $\&$ pe pristi wiste be experience what sauour pat his mete $\&$ his drinke hadde. pe naked man blessid bothe him and his schepe. pe weiferande at his zate hadde free entre. Al boow pese werkes ben comendable zit pe pacience pat he hadde in his pouerte: is before al pese rehersid in pulpit. Sodeyn slawter of his childryn. seknes of him self. pe los of his goodes were ouer weyk: for to opin his lippes folily to grucche. O. blessid Iob so what worschepe is pis! Pi dedes prechen alle men how pei schul be pacient. Seli were pe creature pat wolde folwen pi steppes. It myght be seid of sich on pat he was born to be a myrrour of sufferaunce to men in desese.

8. pat. $M S$. pa.

18. $M S$. \& pat opur side.

21. Wanne he ... This sentence is written a second time in the MS.: When he was in his flowres of worldli auere his handes weren euere open to pe dedis of mercy.

22. MS. faderes.

31. $M S$. pat pat. 
simulque quam pauper ille hortulanus: hic pistor reliquias temporum necessarie debitas quieti: tanta animi vis erat: philosophicis ille vigiliis dedicans: hic scribendis quas venderet Comediis Lactantius Firmianus vir doctrine multiplicis: rarique inter suos eloquii: filii quoque summi principis magister.

5 Idem summa rerum omnium: etiam communium egestate vitam egit. Pauper natus est Flaccus: Inops vixit Pacuvius: Inops Statius. Uterque victus causa : fabulas vendicavit. Inops demum aliquando Virgilius: donec preter suum morem: opes ingenio accessere. Multa sunt talia quolibet hominum in statu: Et omitto illos quoniam nimis multi sunt: qui celestium opum desiderio: non inopiam modo sed famem: sitim: nuditatem et extrema omnia in terris: non equis tantum sed letis atque exultantibus animis elegerunt. Si his quasi exemplis humilibus atque terrestribus non moveris: Ipse celi dominus hic pauper fuit: it exemplo doceret hanc inopie viam esse: qua tamen ad veras divitias pergeretur. Ipse inquam per quem reges regnant: pauper natus: pauper vixit: nudus obiit: cui cuncta interim obsequabantur elementa: Tu homuncio domini tui sortem ters moleste: nec inepte pudet insolentie. Certe quisquis illum cogitans se virtute vallaverit: in ipsa paupertate ditissimus nulliusque egens rei: opes regias non requiret. (II. Dolor. Nulla mihi opum copia est. II Ratio. Ut animo inopi ac deiecto nulle sufficiunt opes: Sic diviti atque erecto nulla non sufficit paupertas: Nempe ille alieno nititur: hic proprio fidit: Edificare in alieno iactura est: questus in proprio. I. Dolor. Pauperrimus sum. I. Ratio. Si necessitatibus obsequeris: pauper numquam esse potes: $\mathrm{Si}$ cupiditatibus: numquam dives. $\mathbb{0}$, Dolor. Hactenus pauper: immo mendicus sum. $\mathbb{0}$, Ratio. Fortuna hominum non stat: et ut summis ex opibus ad inopiam extremam:

25 sic a paupertate ultima ad divitias magnas creber est transitus. Legisti reor apud Quintum Curtium historicum: ut Abdolominus quidam Alexandri iussu seu permissu: ex hortulano inopi Sidonis rex: et contemptu regni maior est habitus quam regno. Certe quod non legisse non potes : Et Romulus e pastorali tugurio tante urbis conditor romanum primus diadema suscepit:

30 Et regum sextus ex humillima: utque aliqui credidere: e servili fortuna ad ipsum regni culmen ascendit: nec Alexandri Priamide: nec Cyri illius inter Persarum reges famosissimi inter opulentiora primordia: aut alia fere sunt rudimenta quam Romuli Gaius Marius qui fuisset et futurus sepe esset Rome consul: et antequam honorum gradus ullos attingeret: mercenarius arator primos in arvis vite annos egerat: et deinde post tot victorias ac triumphos: interque illos suos septem consulatus: preter latebras palustres ac carcerem exiguum quoque mendicavit panem. Julius Cesar futurus mundi dominus: et testamento dominos mundi relicturus adolescens pauper fuit. Tu hac talium comitiva non potes aut sperare opes aut contemnere. II Dolor. Solito

40 pauperior sum. II Ratio. Bene habet et solito eris humilior: expeditior: liberior. Vacui amant incedere qui arduum iter agunt. Carebis solitis opibus: simulque solitis muribus ac furibus et protervis servis: hisque quibus solent abundare divitie: fictis amicitiis: sequacibus atque tenacibus parasitis: totoque illo grege domestico arridentium tibi teque ridentium atque rodentium. Denique

17. Ven. ditissmus.

34. Ven. anttingeret: mercennarius. 
II ADUERSITE: Sum tyme per was no jongkerie but I whas per atte. Now pouert partip felowschep.

II. RESOUN: A noble dyuors! pat departip a man fro wast expun-

186b ses. Now may pou be certein // with owten inquisicioun who hap 5 ben pi feined frendes. Poow pi dore stond wide open. flateres wole passen bi. jdel men with per feet schul not defile pi preschfold. jogolours $\&$ japeres wolen not liste ones to loken on pe pak of pin hows. Pof pis maner men be ful of pi cumpanye! it is no gret charche. Pouert may not breke pe bond of true felowschep. for $\&$ evere 10 haddest pou feithful fere zif he may more pan pow: now schalt pou be dere to hym. $\&$ if pou be elles. man of oni vertu. sad man $\&$ whizs wol joize of pi presens. Alle only dame pride $\mathcal{E}$ here nyse dowteres haue scorn of pore men. Who so dispisith pe pore for non opur cause but for pei be pore! in pat alle pore he dispisip. \& so dispisith he Crist pat was most pore.

II. ADUERSITE: I ham wondur pore.

đI. RESOUN: Pou were bore wel porer \& so schalt pou passen. Flater fortune neuere so faste a man in his middil leuynge sche may not lette pouerte to drawe bope endes of pis dedly lif. Euere pe 20 euyere chere pat pe world schewep pe! pe gladder schalt pou be to part from his felawschepe. $\mathbf{P} e r e$ is no man as I wene pat lift here so pore. but he schal wille at his ende. pat he hadde lyued porer. ne no man suffrep seknes be it neuer so greuous: but he schal desire wanne dep komep pat he hadde suffred mech more. As pou art pore of money! be pore of spiryzt. $\&$ panne hap Crist be hight pe: pe kyndom of heuene.

22. MS. he superscript between but and schal with caret in between. 
si amissas opes cum amissis tediis conferas: lucrum voces. Certe ut securitatem sileam: humilitatem: sobrietatem: requiem: modestiam paupertatis comites: si nihil boni aliud illa secum afferret quam quod et fallacium gregibus adulantium et servorum tyrannide superborum liberat: abunde erat cause ut non ferenda

5 modo esset sed optanda: immo etiam arcessenda pauperies. Sed iam satis sit: Maior enim quam pro re querela est: quam in te mirarer: nisi olim ferme in omnibus notassem nullum gravius: nullum crebrius lamentum: adeo nihil inter homines paupertate melius nihil odiosius. a Dolor. Pauperior sum in vita. $\mathbb{a r}$ Ratio. Eris letior in morte. Nemo tam pauper vixit: ut moriens nollet 10 vixisse pauperior.

\section{(1, DE TENUI VICTU DIALOGUS $\mathrm{x}$}

(1. Dolor. Tenuis victus est mihi. I. Ratio. Et tenuis voluptas et munda sobrietas. An te gule studio contrarium malles? II. Dolor. Asper est victus. II Ratio.

15 Equanimis fer gule illecibris caruisse: cum ad manum sint alie dulciores et queri faciliores et servari. Habet et suas virtus illecebras: Ciceronis utor verbo: has gustare et ruminare cum ceperis: illas magnopere non requires. II Dolor. Durus est victus. II, Ratio. Duricies amica virtutibus: mollicies voluptati. Quot autem magni viri ultro se voluptatibus abdicantes: hunc quem tu 20 refugis victum elegere: quorum aliqui cum possent laute vesci: panem et aquam in delitiis habueve? An vero voluptati quenquam sic obnoxium opinemur: ut non illam valde oderit si adiunctum illi dedecus intueri oculis possit? Sed funesta suavitas: virtutum hostis acerrima et titillatio bestialis: quam qui sequitur: homo quidem videri potest: vere autem animal brutum est. Ad hec et familaritas contracta cum vitis et consuetudo rerum pessima: mortalem prestringit obtuitum: ut discerni nequeat: quam decorum sit quod torqueat fedumque quod mulceat. II Dolor. Nimis angustus est victus. CI Ratio. Immo nimis ampla: nimiumque capax gula est. Unum visu angustum: ve autem unum omnibus in animam irruentibus vitiis patens iter. Hac flamma

so libidinum: hac torpor ingenii: hac irarum et iurgiorum fervor ingreditur: hac imperiosa cupiditas omnia pati iubens: atque facere dum necessaria creditis: que damnosa sunt et munimen vite dicitis: quod ruina est. Hac invidie faces et emulatio implacata indignantibus animis: tam gule alium obsequentem quam vos esse gloriamini: inde laudem sperantes: unde pudor metuendus erat. Hac postremo superbia dum inflatus nec se capiens venter: animo suum affricat tumorem: et persuadet illi esse se homine aliquid maius: quod ambrosia et nectare pastus sit: vides ut vitium unum ex omnibus aditus: neque hunc si aliter nequit inopie vectibus clausum cupis. $O$ paupertas amabilis: que continentie tibi sumis officium. Utile est cogi ad id quod facere 40 tua sponte debueris. I. Dolor. Tenuis me victus extenuat. II. Ratio. Malles ne igitur tumefieri? Hec tenuitas podagram tuis pellet e finibus: dolorem capitis auferet: cerebrique vertiginem vomitumque et ructum et nauseam et sudorem tediumque et fastidium tui ipsius: pallorem alternum ac ruborem: odorem quoque et oris et corporis tibi atque aliis importunum sistet. Preterea pedes 45 instabiles: manus tremulas: nutans caput: quodque est optimum: animum 
ADUERSITE: My fare is ful pinne of mete $\&$ of drink.

T. RESOUN: Din fare. pi(n) lust: pi soburnesse is pe more. Dou haddist leuere be a glotoun but pi weize is stoppit. \& wel. for 5 glotenye is a modur to alle maner of visis. With here stikkes sche fedith pe flawme of leccherie. \& slawt kan sche make slepe al nyzt in his hode. When men ben pechir prouzd. panne risith bate lithly. penne bost kan not holden his pees. grete opes fle faste. Be a fool drunken. he is whise jnow he passith in his owne opynyoun. a meyster of diuinite. What schulde I more seye? Glotenye transformeth a man in to a beeste. Pis is a gret vilanye. who so hadde eyzen to se. Feble fare remouyth occasioun of pese harmes. Dis is not a litil god.

II ADUERSITE: I haue but hard fare.

15 II RESOUN: Hardnes is freend to vertu. \& softnes to lust. It was $\mathcal{E}$ is pe manere of deuouzt men wilfulli for to chese hard fare pat pou hatest. of whom summe pat myghte have had alle maner deyntees: hadde delit to be fed a mong with bred \& water. Perchaunce pus hast pou rad pi self. but I ham a ferd lest pou suffre pe

20 same febre pat is a mong clerkes comyn. Summe whanne pei reden of pe abstinence of Jerom $\&$ German $\&$ of pe pacience of Job it tikelith pe eres: but wanne pe asaye to soujpe of pe same broth: panne is it so bitter pei may not per of. Manye studien seche stories: not for pei wolde lifen betere. but for to kunne talke of perfeccioun.

$25 \&$ what is more veyn?

187 (I. ADUERSITE: Selden go I to bedde with ful douzblet. //

II RESOUN : Pou wakest at morn meche pe merier. Pe nedest not

2. Aduersite: Capital illuminated.

3 MS. pi. 
ipsum moderabitur frenabitque Et quid igitur tam multa corporis atque anımı bona parvo cibi desiderıo ac momentaneo gustus incommodo tibı parta conquereris dignus his preditıs gustuı deservire ? I. Dolor Tenuis victus me fatigat $\mathbb{C}$ Ratio Contrarius fatigaret nisi forte onus requiem vocas

5 Num legisti lautioris vite tedia magna esse ita ut quinque diebus continuis non possit sine fastıdıo tolerarı ab homınıbus temperatis et altiora spectantibus quam palatum et ventrem? $\mathbb{I}$. Dolor Supra modum victus est tenuis II. Ratio Fuit etas quando hic fuisset et est adhunc gens alıqua ubi esset victus amplissimus Verum mundo in detenus lapso vos deterrımı omnium

10 esse nitimin publice semper principes rune ut qui optımı omnium fuistis versis usquequaque vestıgis sitis omnium pessimı et in temporum vitus ac locorum precipuum teneatis gradum $\mathbb{C}$. Dolor Victus tenuis mihi non placet II Ratıo Victum tenuem et virtutis et voluptatis amatores ac patron laudant $T u$ quam heresim sis amplexus nescio Plato Syracusias menses

damnat nec ullo modo sibi placere ait bis in die saturum frerı Epicurus in oleribus suis voluptatem ac delitias ponit et hunc quem tu fugis victum rebus ac verbıs probat Denique ut ait Cicero Nemo de tenuı victu plura dixit Tu duarum notissimos si viarum duces spernis quid est reliquum nisi ut impetu tui errons et virtutis hostem nec amicam voluptatis onerosam

20 sequans ingluviem fedum finem nec tam hominis quam iumentı quodque indignanter ac dolenter dixerim iumenta mulium quidem sed pro captu suo ventri ingerunt Solv vos animantium domin mensuram vestram et nescitis et frangitis Neque de nuhlo est quod multı mirantur qua patrum et avorum memoria vinee multo pauciores essent homines autem totıdem aut plures vina tamen viliora erant Sic in dies crevit ebriorum sitis a. Dolor De lauto victu ad tenuem sum redactus $\mathbb{a}$. Ratio Bene habet quod modestia neglexit implet inopia Optımum est sponte agere quod debeas proxımum vel coacte

\section{G. DE ORIGINALI INOPIA}

C. Dolor In paupertate etiam natus sum (II Ratıo Quis non nudus utero matris egreditur? Nil hic precipuum habent reges (II. Dolor Antequam nascerer pauper fuı ar Ratio Bone memone es si meministı delicacissimus si sensistı (I. Dolor In paupertate sum genitus II Ratio An tue tibi quer1monie parum sunt? Hec non tua quidem sed parentum fuerit बi. Dolor In paupertate natus sum ol. Ratio In paupertate moriturus Similis prncipio finis manet nisi forte monentis langoribus meden aurum censes quod in arcule fundo est o. Dolor In paupertate vite mihı principium fuit G. Ratio Medium false sepe divitie at principıum et finem vera paupertas tenet

40 nudum nasci nudum mon humana vere conditio est Nam quid queso purpureum cuble quid funeralis lectus aureus et quecumque sub ipsum vite finem mortalis ambitio meditata est quid ad febrem quid ad mortem ipsamque de qua loquimur morientium nuditatem? An ut equum phalere sic panetem aule delectant? Mulcere ista oculos possunt intuentium Sensu carentibus delectabıle alıquid inesse potest delectatio autem nulla đi. Do- 
to conseille with pi stomak wanne pou schalt rise. Pe odour of pi mowth $\&$ of pi bodi bope schal be lesse inportune to pe $f$ to opere. Dou schalt not nede to wynde pi tepet for pe hed ache. De podagre fro pi feet schal be pe ferper. \& for to seyze schortly. pe phisisian 5 schal haue pe lesse of pi moneye. Mete $\delta$ drynk schulde be taken be maner of medycin for to susteyne kynde pat schulde elles faile. Vnresonable bestes poow pei eten meche: zit pei kepe pe mesure pat nature hath tawt hem. but man pat schulde be here lord kan no rule kepe. It is wreten pat for surfet many on hath perched. ze glotenye 10 sleeth mo pan pe sweerd doth. O. amyable pouerte pat compellith pe gredi to be mesurable. profitable is pat nede pat constreynep a man to ping pat hym awte to do. with his good wille.

II. ADUERSITE: Per kummep no vitalles on my bord but simple \& pore.

II RESOUN: Wel I haue aspied. pat pou $\mathcal{E}$ lust wolde kisse. were it not pat pouerte kepith zow on sund $u r$. Many men per be as presoneres \& opere pat wolde receyue with a lawyng chere seche vitailles as pou letist litil by. Hungur dispisip no maner of mete. pou mayst no betere plesen hym. pan driue hym a wey. Haue he

20 barly bred or a ryze kake! he wol not a bide. to pou seende for symnelle to pe bakers houzs. Haue he a mes potage $\&$ stor of houzse him pinkith he hath // a feste be pe wombe ful. Nature lokep after no delicacies. but pe lippes of lust be so likerouzs him liste not euen soupe. but 3 if he haue wilde foul. Peniale is to him odious. His delicate appetite is his phisicion. What mete sauoreth him best. pat pinkep him most holsom. Sich a beli seruaunt hap no consideracion! how pe more likerous pat pe mete is: pe sunner it bringith a man to do surfet. Pe apostele Paule was of an oper scole. for pus he writith to Tymope: Haue we our sustinaunce $\&$ clopes to kouer so vs hold we vs content. Neper he speketh of swete morselles neper of skarlet robes. but of liflode necessarie. Seyntes couden ete wel jnow poow pe powder box bleuz not on here sawser. For haue pe seruaunt of god hungur \& salt: he wol not be angry for oper sause failyth.

II ADUERSITE: I dele with non deyntes. I haue but homly fare.

II. RESOUN: Bou art pe more able to sorwe for pi synne. Crisostom seyzt. pat as it is inpossible fire to bren in water! so it may not be.

16. MS. pat superscript between not and pouerte with caret in between.

33. $M S$. seruuaunt. 
lor. Nudus inops natus sum. (II Ratio. Humanas res pene omnes alterna sors variat: Eadem quasdam equat quo reliquarum soletur imparitatem: harum prima et maxima est ipsa hec originis ac mortis equalitas. Multi et varii viventium sunt amictus: nuditas una nascentium atque morientium:

5 nisi quod illi multa reperiunt ignari : hi omnia deserunt scientes : ut exigui damni sensum debeat ipsa rerum pereuntium lenire cognitio. đI. Dolor. Nudus in hanc miseram vitam veni. II Ratio. Id recolens animo equiore abibis nudus. 
pat contricioun prife a mong delices. \& skele whi. delices causen lawter $\mathcal{E}$ myrpe. $\&$ contricion is $\bmod u$ r of weping $\mathcal{E}$ heuynesse. We reden in pe olde lawe. pat hony was forbede in pe sacrifice of pe lord for to be offered. in fugure. pat lusti leuyng wich is to meche 5 folk swete as hony. is not to god acceptable but a meke spirizt pat is holili trubled $\&$ contrite of his wickidnes. sendith vp to heuene a swete smellynge offryng. O. swete Ies $u$ pe bitter galle pat pou tasted in pi passioun is ful fer fro pe mynde of a likerous glotoun. Man whan pou grucchest for pou farist harde! woldest pou suffre pi

10 mynde to // wete pi mete in Cristes wondes pou myght fynde no betere sause to make pi mete sauery. Pe wateres of Marath were so bitter pat pe folk of Israel mygth not dryngen of hem. Penne god schewede a tre to Moyses. wich wan it towchede pe flod. a non it was turned in to swete licor. Dis tre be tokenep pe cros of our sauiour. wich \& it were wel inpressid in a mannes herte: not al only hard fare of mete $\mathcal{E}$ of drynk. but also oper tribulaciones it schulde turne to swetnesse.

(I) ADUERSITE:

3. ony corrected to hony by superscript $\mathrm{h}$ and caret, with hony in outer margin. 


\section{NOTES}

N B The sources noted in this section do not imply that Petrarch or the English adapter necessarily had recourse to any of these sources directly, but simply intend to indicate the general currency of the ideas among moralistic writers The cumulative effect of the type of borrowings is a useful indication of their reading interests It becomes clear to what a large extent Petrarch, too, apart from his classical references, draws on the bible commentaries, homilies, saints' legends, the 'dust of apocryphal invention' and, in general, the storehouse of medieval moral instruction In some cases the English adapter explicitly provides the authority where Petrarch is silent and, from the wording of some quotations, it would seem that he checked the sources and sometimes quoted from them independently See e g note to 23/35 Seneca is often quoted, but in most cases the Flores Doctorum (see $\mathrm{p}$ [4]) may have been the intermediate source, sometumes quoted independently by the excerptor

\section{OF VNSEMELY SCHAP}

3/9 farve fetoured bodi \& clennesse of souzle selden nestele per to gedere Cf Juvenal, Sative X, 297 'Rara est (adeo) concordia formae atque pudicitrae' This poem 'On the Vanity of Human Wishes' was very congenial to the moralising Middle Ages (see also note to 27/15) All the assets of prosperity, beauty, long life, nches, power, pride of place, etc, are deflated in this depressing and pessimistic poem

3/18 spoilip nature of his rizt Cf Augustine in Lib Ser Dom quoted in Flores Doctorum under 'ornatus' 'Quanta amentia est, effigiem mutare naturae, picturam quaererel' The argument that cosmetics are 'unnatural' and insult 'God's image' is a common feature of medieval denunciations of fashion

3/19 I ham had in despit According to the medieval physiognomists deformity of body pointed to treachery of character Cf the English translation of Secreta Secretorum. E E T S E S 74, p 231 'And thay whyche bene 11 mesurid of body bene dysposyd to trechury and othyr ill tecchis And thay wyche bene wel mesurit of body ben Iuste and ryghtfull men' 3/22 Deformite of bodi defilith not pe souzle Cf Seneca, Epistulae Morales, 
66,4 quoted in Fl Doct under 'ingenium et ars' 'Non enim deformitate corporis foedatur animus sed pulchntudine anime corpus ornatur'

3/24 Thamar On Thamar and Amnon see II Kings, xu

3/27 For linl worth is pe blosme Possibly an allusion to the proverb. 'Beauty is but a blossom' (Oxf Dict Eng Prov)

3/32 Whanne per of borwed her feynen hem hornes (When they show off their imitation horns of borrowed hair) Cf e $g$ Ayenbite of Inwyt, E E T S O S 23, p 176 ' po pat makep zuo greate hornes of hare here/oper of opren/ pet hı semblep wel fole wyfmen' Borrowing not only of harr, but of clothes for proud display, was frequently denounced by preachers Cf Handlyng Synne, $113457 \mathrm{ff}$

5/1 falle per fro fayrnesse to pe liknesse of Lucrfer For simnlar illustrations denouncing the foolishness of women's tollet see John Bromyard, Summa Predicantium under 'ornatus' and G $\mathrm{R}$ Owst, Literature and Pulpit in Medieval England, 2nd ed, Oxf 1961, pp 390-411

$5 / 8$ pi bodi schal be bryghter seuene sithe panne pe sonne is now This is not found in the Bible but it occurs in the Elucidarium III, 79 ( $l^{\prime}$ Elucidarium et les Lucidarres, par Yves Lefèvre, Pans 1954) 'D At dic qualıa corpora habebunt sanctı M Septies quam sol splendidiora et prae animo agihora' The genesis of the idea can, however, be reconstructed from the B1ble It is said that the blessed will shine like the sun (Matth xul, 13) which on Judgment Day will shine seven times brighter than it does now (Isa, xxx, 26)

5/10 Dus enformeth vs Austeyn pe doctour Augustine discusses the splendour of the body at the resurrection in De Civitate Dei, Bk XXII, Ch 19, which is also the source of the following quotation in Fl Doct under 'resurrectio': 'Resurgent sanctorum corpora sine ullo vitio, sine ulla deformitate, sine ulla corruptione, sine difficultate in quibus tanta facilitas, quanta felicitas erat'

$5 / 13$ Glorious to pe eyze is a long stature but more sunpper is pe schort comynly or more spedi Cf the Latin longe conspectior est statura brevis expeditior agiliorque Some other editions have longa for longe and different punctuation Longa might then be taken as ablativus comparationis or as subject Longe, the adverb, leads to the following translation by Thomas Twyne the lowe stainre is more comelie, light, and nimble Our translator must have had a text with longa, he translates it as a nominative

5/15 What forbedep a meche man to inhabut a low hows' So may a gret souzle wonen in a schort body Cf Seneca, Ep Mor , 66,3. 'Potest ex casa vir magnus exure, potest et ex deformi humilque corpusculo formosus anımus ac magnus exure' Quoted in Fl Doct under 'ingenium et ars'

5/16 Nouzt I mene pat pe souzle schulde of quantite be gret Possibly an allusion to Augustine's De Quantrtate Anzmae (Migne, $P L, \mathrm{t}$ XXXII, col 1037) 'Euodius dic nunc quanta sit anma Augusinns Quomodo quaeris quanta sit? Non enim intelligo utrum ejus quası spatium latıtudinis vel longitudinis, vel roboris, vel horum simul omnium requiras, an quantum valeat nosse velis'

5/18 pe bee is but a litıl thing Cf Ecclus xu 'Non laudes virum in specse sua 
neque spernas hominem in viso suo, brevis in volatılıbus est apıs, et initıum dulcorss habet fructus illius'

$5 / 22$.. 3if god wele $2 t$ suffre. The Latin has: 'si sors tulent'.

$5 / 25$ Iesse. The Wyclif Bible has Isa1 or Ysa1

5/27 Helyab, Eliab, cf. I Kings xv1, 6 .

5/29 Six cubites, of I Kings xvu, 4: 'altitudinis sex cubitorum et palmu'.

5/35 A fyn sweerde is ofte houjsed in a roten schepe. Proverbial' See below, Style and Proverbs, $\mathrm{p} 78$.

5/36 A strong souzle (is) ofte herbored in a feble bodı. Proverbial, cf. H. G. Bohn, $A$ Hand-Book of Proverbs, London, 1885. 'A little body often harbours a great soul'.

5/37 Pevauenture pou hast abeste to honeste studue The value of 'honest study' is typical of the humanists' message Whereas Petrarch in an anstrocratic vein contrasts the low workman with the magistrate, the English adapter here prefers to stress the contrast between the questionable fame acquired through wrestling and tournaments, and the glory of wisdom as praised in the Brble. See next note.

7/1 Redines of conseil ... made hem to sitten weth princes. Cf Ecclus. x1, 1: 'Sapıentıa humıliatı exaltabit caput illus et in medıo magnatorum consedere llum faciet'

7/4 Josue, Judas Machabe, Ector \& Arthour They belong to the 'Nine Worthies' whom 'Fame holds in remembrance'. This theme continues till long after the Middle Ages. See also Chaucer, The Monk's Tale, Hawes's Pastıme of Pleasure has the above figures plus five others. Maccabeus was adopted also as a hero of romance.

7/6 In pinge pat moste nede fanlep a gentıl souzle hap no delit. It is not impossible that the $\bar{p}$ in faile $\beta$ is a scribal error. The Latin has: Nil potest delectare magnum animum quod non duret Compare also Seneca, De Brevitate Vitae. xvil, 4. 'Neminem porro casura delectant'. The sense without the $P$ would be: 'In a thing that must needs perish a noble soul has no delight'. However, as the text stands it makes tolerable sense: 'In a thing that does not meet the greatest need a noble soul has no delight'

$7 / 10$.. nepur he $3^{2 t}$ as an hors or an ollfaunt Cf. Boethus, De Consolatzone, Bk. III, Prose vu, 4: 'Non enim elefantes mole, tauros robore, tıgres velocitate prehibitis'.

7/11 Eche ping hath his mesure. Proverbial.

7/18 Paule pe apostle Petrarch does not mention Paul or Peter 9/27 by name but uses a long-winded circumlocution

$7 / 20$... pe flesch is rebel... Cf. Paul to the Galatians v, 17.

7/21 . . pi famyliar enemye. . Cf Cicero in Verrem II, 1, 15, quoted in Fl. Doct. under 'inimicus': 'Nulla pestis efficacior ad nocendum quam famulians inimicus'. Also in Boethius, De Cons., III, Pr v. Cf. the proverb 'Nothing worse than a famliar enemy'.

\section{OF SIKNES}

9/1 Hinderyng of pe ton is forthing of pe topere. A frequently expressed idea. 


\section{NOTES}

Cf. 'St. Bernard on Man's Three Foes', Minor Poems of the Vernon MS., Part II, ed. F. J. Furnivall, E.E.T.S. O.S. 117, p. 511 f., 1l. 74-78: 'And pat is pi flesch, pi furste fo, / pat pou pamprest and seruest so, / zif ich hit dorste seyen. / pou dost pi souzle muche wrong, / Whon pou makest his fo so strong / To fihten him azeyn.' Cf. also Fl.Doct.: 'Fortitudo corporis est imbecillitas animae et rursum imbecillitas corporis est fortitudo animae', quoted from St. Jerome.

9/6 Greuous infirmite makip sober souzle. Cf. Ecclus, xxxi, 2: 'Infirmitas gravis sobriam faciat animam'.

9/7 A bridel of arest. The figure of the bridle and the comparison of man's passions to a wild horse is very common, also in art. Cf. D. W. Robertson, A Preface to Chaucer, Princeton 1963, pp. 253-54 and fig. 6. Similarly Ayenbite of Inwyt, E.E.T.S. O.S. 23, p. 204 where the bodily wits are likened to a horse without a bridle, which should be restrained with the bridle of reason. For a biblical source see Ep. Jacobi, iii, 3.

9/8 Rebukip him with a scourgyng. Cf. Ecclus, xxx,1: 'Qui diligit filium suum assiduat illi flagella' and the proverb: 'Spare the rod, spoil the child'. cf. Bede, 'Proverbiorum Liber', Migne, P.L., t. XC, col. 1091: 'Qui parcit virgae odit filium'.

9/9 Depertip not pe fleil pe corn fro pe schaf? Cf. Petrus Blesensis, De Duodecim Utilitatibus Tribulacionis, (P.L.,t. CCVII, col. 994): 'Sicut flagellum cogit granum exire de palea, sic tribulatio cogit cor humanum ab amore humano separari, quia mundus displicet cordi tribulatio'. Similarly the Eng. tr. in Horstmann, Yrksh.Wr. II, p. 50.

9/10 A bittur drinke purcheth wikkid humour. Cf. De XII Util. etc., col. 992: '...nam, sicut amare potione purgantur mali humores, sic per tribulationes purgantur animae mali mores'. Attributed to St. Gregory in the English version, MS Arundel 286, fol. 103: 'ffor seynt gregore seip: rizt as pe bittur medicyn purgep pe wicked humours of pe body! so tribulacioun purgep pe wicked condiciouns of pe herte'. cf. also Adam Scotus of Dryburgh, Soliloquium de Instructione Animae, cap. III (P.L., t. CXCVIII, col. 849): '.. nec sine amara potione noxius a mentis stomacho humor ejicitur'.

9/10 Wel worth pe wand pat makip wilde childer tame. Proverbial. cf. J. Werner, Lateinische Sprichwörter uxd Sinnsprüche des Mittelalters, 2nd. rev. ed. by Peter Flury, Heidelberg 1966: 'Indomitos pueros aspera virga domat'.

9/15 A bitinge plastere... 'mordax emplastrum'. Not in the Bible, but cf. Biblia Latina cum Postillis Nicolai de Lyra, Venetiis 1489, the commentary on II Corinthians, xii: 'Propter quod. Hic consequenter ponitur circa dictum remedium Apostoli petitio. Circa quod sciendum quod infirmus ignorans medici processum, quando imponit sibi mordax emplastrum, rogat medicum ut removeat ipsum: quem tamen medicus non exaudit ad nutum, licet exaudiat ipsum ad bonum suum, sciens infirmitatern suam aliter non posse curari'.

9/18 How precious a juel... Cf. I. Cor. vi, 20: 'Empti nam estis precio magno'. 9/25 Mi grace sufficy $p$... II. Cor. xii, 9.

9/28 Pernylle. Not mentioned by name in Petrarch. The story of Peter's daughter Petronilla, who died as a Christian martyr in defence of her purity, 
can be found in the Greek Apocryphal Acts of Nereus and Achilles (Hans Achelis ed., Acta SS. Nerei et Achillei, Texte und Unters. zur Gesch. der Altchristl. Lit., Bd. 11, Leipzig 1893).

Her legend is also found in the South English Legendary, MS Vernon fol. $31^{\mathrm{b}} \mathrm{f}$. One of the Minor Poems of Lydgate is devoted to The Legend of St. Petronilla (E.E.T.S. E.S. 107, Part. I, pp. 154-159).

9/30 Paule 3af him not preizere to hele sik Tymope... See I. Tim. v. 23: 'Noli adhuc aquam bibere, sed modico vino utere, propter stomachum tuum et frequentes tuas infirmitates'. In the commentary of St. Jerome (P.L., t. XXX, col. 885): 'Dat ergo ei consilium, ut plus doctrinae causam, quam abstinentiae curet: et simul ostendit quas infirmitates creaturum medicina possit sanare'. The argument of this illustration and the one of Pernylle is that Adversity should not propose his own remedy, where Peter and Paul gave diametrically opposed advice. Hence the conclusion: 'What wost pou what is speedful to pe?'.

9/32 Comytte pe cure of thi bodi to pe souereyne leche... Cf. De XII Utilitatibus, $P . L .$, t. CCVII, col. 989: 'Suscipe igitur cum humilitate medicinam tibi a Domino missam qui est summus medicus cognoscens intimam complexionem cordis tui, quia scit quantum potes sustinere, et nihil tibi dabit nisi quod utile tibi fuerit'.

11/1 His presoun is ruynouzs... The idea of the body as the prison of the soul is, of course, extremely frequent. For a biblical authority see Paul, II. Cor. xi, 25-27.

\section{OF VNNOBLE CUNTRE}

11/22 Place makep no man holy: but man makep holy place. Proverbial, cf. A. Otto, Die Sprichwörter und sprichwörtlichen Redensarten der Römer, Leipzig, 1890, p. 196: 'Homo locum ornat, non hominem locus'. Also in Bohn: 'It is thou must honour the place, not the place thee'.

\section{OF PORE BIRPE}

13/8 Among pi progenitoures. pou schalt haue alle pe hole preisinge. Cf. Chrysostomos in Matth. IX, 7, quoted in Fl.Doct.: ' ...qui autem de contemptibili genere clarus egreditur, rota gloria claritudinis cius solius est'. Petrarch borrows here extensively from this homily of Chrysostom.

15/10 Affter pe frute is pat is lengest abiden. is a tree demed good or badde. This seems to be a compromise between Petrarch's text: 'De principiis enim labor: de fine fructus qui si immaturus carpitur: longevus esse non potest' and the biblical proverb: 'A tree is known by its fruit'.

15/14 Dus seith pe philosophur Plato. pat per is no kyng but he kam of seruauntes... Cf. Plato, Theaetetus, Loeb ed., p. 174, E. Quoted in Seneca, Ep.Mor., 44,4: 'Platon ait neminem regem non ex servis esse oriundum, neminem servum non ex regibus'.

15/16 Sauzel... wente to seken his faderis assis. I. Kings, ix. Saul, when seeking his father's asses met Samuel who recognized him as the future king of Israel. 
15/23 O. swete Iesu. pi most pore natiuile schul descounfed oure prouzde hertes... St. John Chrysostom's Homily on the Gospel of St. Matthew, iii is devoted to the theme that the poor birth of Christ should teach us never to be ashamed of our ancestry.

\section{OF BIRTHE IN LECCHERIE}

17/1 Of bivthe in leccherie. In some MSS and printed editions of Petrarch's treatise (e.g. the printed edition of Le Preux, Bern 1595) this is given as De Obscura Origine. This may be due to confusion with dialogue IV or to misreading of De Obscena Origine.

19/5 Or what noizede it Abraham pat his fader Thare dede honour aliene goddes? This illustration is not in Petrarch, but see Chrysostom's discussion of nobility in Homilies in Matth. IX, 7, quoted in Fl.Doct. under 'nobilitas': '...quid nocuit Abrahae quod patrem habuit Tharam luteorum deorum cultorem... nec potuerunt eius gloriam sordidare paterni errores'.

19/6 In ech preisynge ... propere dedes ben to be charched. For aliene vertu... is non man iustli preisid... Cf. Seneca, Ep.Mor. 41: 'In homine quoque illud laudandum est quod ipsius est... Quid stultius est quam in homine aliena laudare?' Quoted in Fl.Doct. under 'laus'.

19/16 Pe sone schal not bere pe wickidnes of pe fader... Cf. Ezekiel, xviii, 20: 'filius non portabit iniquitatem patris'.

19/17 Doow pe comen lawe inhibete pe to take holy orderes... One would expect 'canon law', but it is not necessary to assume scribal confusion. Comen lawe must here refer to the common law of the Church, hence the general law as opposed to provincial constitutions, papal privileges, etc.

The prohibition against illegitimate children-and sons of priests, deacons, subdeacons and canons-taking orders is first recorded in a number of documents dating from the end of the eleventh century. ${ }^{1}$ It arose within the framework of the so-called Gregorian Reformation of the Church which took a strong line against the widespread secularization of the clergy. ${ }^{2}$ In particular this prohibition was directed against the common practice of finding ecclesiastical careers for illegitimate sons of the nobility and the clergy, who in the secular sphere were debarred from enjoying their patrimonial heritage.

Though the above decretals had at first a restricted application they became part of the general canon law in accordance with the custom of basing the

1 Synod of Poitiers, 1078, canon 8; further in a letter of Urban II of 1089 (ed. Migne, P.L., t. 151, letter no. 24, col. 306); canons 11 and 25 of the synod of Clermont, 1095, also under the supervision of Urban II; and the Decretum Gratiani, $1140-42$.

2 Cf. A. Fliche, La Réforme grégorienne et la Réconquête chrétienne (1057-1123), Paris, 1946 in A. Fliche et V. Martin, Histoive de l'Eglise, vol. 8, p. $281 \mathrm{f}$., which gives the text of the prohibition together with comments on the historical conditions. See also the article on Urban II in Dictionnaire de Théologie Catholique, vol. xv, 2 (cols. 2269-2285), col. 2283. 


\section{NOTES}

general law on private constitutions. ${ }^{1}$ The prohibition came to form part of the Decretum Gratiani, promulgated in the years 1140-42, and soon acquired the strength of a decretal of universal application. This custom was implicitly confirmed by Pope Gregory IX when in 1234, he formally pronounced the Liber Extra-which was a supplementary collection of constitutions drawn up after the Decretum Gratiani-as a universally binding part of the canon law.

\section{OF BONDACHE}

21/5 Aristotele wrytip. pat sum men ben seruaundes be lawe. of sum men be kynde. Cf. Aristotle, Politics, Bk. I, Chapter II, 13. This quotation not in Petrarch. $21 / 17$ I rede ones in Job ... Cf. Job v, 6: 'Nihil in terra fit sine causa'.

23/6 De preching of seynt Petre: Be ze seruauntes sogetes to zour souereynes... Cf. I Peter, ii, 18. With the restrictions following cf. St. Jerome's commentary on Paul's Epistle to Titus ii, 9, 10 (P.L., t. XXVI, col. 584).

23/7 trewauntes. The Vulgate text has 'dyscolis', which in the Wycliffite version is translated by 'tyrauntis'. The Glossa Ordinaria glosses 'dyscolis' as 'indisciplinatis', which may have given rise to both 'tyrants' and 'truants'. The translation 'trewauntes' is in accord with the further commentary of the Glossa to I Peter, ii, 18 (P.L., CXIV, 648): 'Schola Graece, Latine locus, in quo ad audiendos magistros liberalium artium conveniebant, unde schola vacatio interpretatur, quia ibi vacabant studiis. Scholastici igitur sunt eruditi. Dyscoli indocti et agreste'. Similarly, both the Catholicon Anglicum, an English-Latin Wordbook dated 1483, (ed. Sidney J. H. Herrtage, E.E.T.S. O.S. 75, 1881) and the Promptorium Parvulorum gloss 'trowant(t)' as 'discolus'.

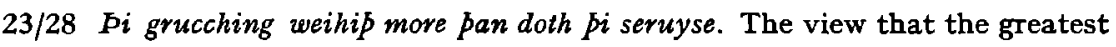
burden is that which we cause to ourselves by our own fancies is found in a similar way in Seneca, Ep.Mor., 78.13: 'Noli mala tua facere ipse graviora et te querelis onerare; levis est dolor, si nil illi opinio adiecerit...' Also Petrarch in dialogue 24 of the second book.

23/31 De myghtes of pi souzle may walke a mong pe ierarchies. Possibly an allusion to the powers or virtues of the angelic hierarchy.

23/35 But Jerom recordep... Cf. Epistola liii (ad Paulinum), P.L., t. XXII, col. 541: '...captus a piratis et venundatus, etiam tyranno crudelissimo (Dionysio Siciliae) paruit, captivus, vinctus, et servus; tamen quia Philosophus, major emente se fuit'. The authority of Jerome is not in Petrarch and the English is based on the above quotation rather than on Petrarch's text.

25/2 Kyng Nabugodonosor... Cf. Daniel, ii. Petrarch has instead the illustration of Terence's rise to fame through his achievement as a writer of comedies, which raised him from servitude to the heights of literary eminence.

25/23 Hismalitis: the Ishmaelites, cf. Genesis xxxvii, 28.

1 A. M. Stickler, Corpus Iuris Canonici in Lexikon für Theologie und Kirche, 2nd ed., vol. iii, cols. 65-69. 


\section{NOTES}

25/28 Trupe... may not be slayn. poow it be beten. Proverbial? Cf.: 'Truth may be blamed, but cannot be shamed' (O.D.P.).

\section{OF POUERTE}

$27 / 15$ zif pou walke be pe kuntre... fyne hors. This passage is a bit obscure and possibly corrupt. The addition of no is only an attempt to make the argument slightly more logical. The general meaning, however, is clear. It is a frequently expressed sentiment in discussions of poverty, ultimately derived from Juvenal's Sative X, 22: 'Cantabit vacuus coram latrone viator'. It is found in Seneca Ep.Mor., 14, 9: 'Nudum latro transmittit; etiam in obsessa via pauperi pax est', quoted in Fl.Doct. under 'paupertas'. It is found in Boethius, De Cons., II, Prose v, in Chaucer, Wyclif, Lydgate and cf. also Speculum Christiani, E.E.T.S. O.S. 214, p. 216: 'Seneca: A riche, couetous man dredes theues or wey-lyers and other men. He sees a strangar man than he, and he wenes he wer a thefe or a rauenour. $\mathrm{He}$ sees a poore man and suppose he wer a robber.'

27/18 A gilt spore: symbol of the knight.

27/22 Also litil as pei may wel lest: pilgrimes irussen with hem. Cf. Gregory, Homiliarum in Evangelia Libri Duo, P.L. t. LXXVI. col. 1233: ' ...peregrinus vitat sui ipsius nimiam onerationem: quanto minus potest secum portat de vestibus et aliis quibuscunque'.

27/25 To wrastele for the swan. Mostly the prize for victory in a wrestling-match was a ram or a cock. Cf. J. Strutt, The Sports and Pastimes of the People of England, new edition by W. Hone, London 1883, pp. 82-83.

27/25 Dei enemye may werst holde haue of pe wanne pou gost alderest bare. Wrestlers had at least the upper part of the body uncovered, cf. A. Wettwer, Englischer Sport im 14. Jahrhundert, Göttingen, 1933, p. 87. The comparison of a poor man to a naked wrestler is not in Petrarch, but can be found in Gregory, Homiliarum in Evangelia Libri Duo, P.L., t. LXXVI, col. 1233: 'Nudi ergo cum nudis luctari debemus. Nam si vestitus quisquam cum nudo luctatur, citius ad terram dejicitur, quia habet unde teneatur. Quid enim sunt terrena omnia, nisi quaedam corporis indumenta?'

27/29 Dere is non bed soft to a seke man. Not in Petrarch, but cf. Seneca, Ep.Mor., 17,12 (trans. Loeb ed.): 'Just as it matters little whether you lay a sick man on a wooden or on a golden bed, for whithersoever he be moved he will carry his malady with him; so one need not care whether the diseased mind is bestowed upon riches or upon poverty. His malady goes with the man'.

29/5 Litil katel: litil kave. Proverbial, cf. Bohn: 'Little goods, little care'.

29/7 Fortune hath fro me taken... This is where in the corresponding Latin of some MSS and printed editions a new chapter De Damno Passo begins.

31/9 Fe sonne clopith pe eire on daies... The changes of natural phenomena are tokens of the variability of worldly things. Cf. Boethius, De Consolatione, Bk. II, Metrum iii.

31/20 While wele $\&$ woo pleyen at pe balle... This representation of the workings of Fortune is not discussed by Patch, The Goddess Fortuna in Mediaeval 


\section{NOTES}

Literature The figure of the ball by the side of the usual wheel is however common enough Cf Chaucer's Truth, line 9 and Lydgate, Troy Book, 1, 1506, 11, 2027 In various medieval illustrations the twin figures of wele and woo (Prosperitas and Adversitas) appear in the centre of the wheel or as the two parts of the castle to which Fortune assigns her guests (Patch, p 143 and $\mathrm{P}$ 164)

31/20 Nepur of hem kan holde longe pe balle stille but hedur \&o pedur $2 t$ (gop) contynuely It seems safest to assume that some such verb as $g \circ p$ has been omitted here by the copyist As the text stands it would mean that hedur and pedur are adverbs converted to verbs governing an object The first instance recorded in OED of hither and thither as verbs is from the early 19 th century and only in an intransitive function

31/23 Fanne is goddis grace ner pan pe bischops dole Possibly a variation on the proverb 'God's help is nearer than the door' adapted to this context Cf Bohn for examples of other variants

31/30 Fro pe may fortune nouzt bere but pat sche may bringe to pe Cf Seneca, Ep Mor , 39, 10 'Nihil eripit fortuna nisi quod dedit' Quoted in Fl Doct Entered as a proverb in Bohn 'Fortune can take from us nothıng but what she gave us'

33/3 How may manye pinges wante where fewe pinges sufficen? Cf Seneca, Ep Mor , 17, 9 (trans Loeb ed ). 'But, you say, I shall lack the necessities of life In the furst place, you cannot lack them, because nature demands but little

33/4 Nede may sone be niche jnow but couetrse seyzeth neuer hoo Cf Seneca, Ad Helviam de Consolatione, $\mathrm{X}, 11$ 'Cupiditate nihl satıs est, naturae etiam parum' and Boethıs, De Cons, III, Pr 111 'Taceo quod naturae minimum, quod avaritiae nihl satis est'

33/5 Als meche as he wolde haue as meche him fayluth Cf Boethius, De Cons, Bk II, Prose v 'verumque illud est permultis eos indigere qui permulta. possideant contraque minimum qui abundantiam suam naturae necessitate non ambitus superfluitate metiantur' Cf Horace, Carmına, III, 16, 24 'Multa petentıbus desunt multa', and Romance of the Rose, English version, 15720 'whanne he most hath, most he fallith'

33/6 Not he pat lest hap. but he pat most couentep' is most pore This 1s modelled on Seneca rather than on Petrarch Cf Seneca, Ep Mor, 2, 4 'Non qui parum habet, sed qui plus cupit, pauper est' Quoted in Fl Doct under 'paupertas', there attributed to St Jerome It is entered as a proverb in Bohn 'He is not poor that hath not much, but he that craves much'

33/19 Were pouerte \& paciens wonen to gedere' pere is rich pouert $\mathrm{Cf}$ Seneca, De Remedins Forturtorum, X 'Qui cum paupertate bene convent dives est' Quoted in Fl Doct under 'paupertas' Cf also the proverb 'Patience with poverty is all a poor man's remedy' (Bohn)

33/21 His handes were euere open Cf Prov xxx1, 20 'Manum suam aperuit nopi, et palmas suas extendat ad pauperem'

33/22 Widwes and faderles childrin Cf Job, xxix, 11-13

33/25 De werferande at his zate hadde fre entre Cf Job, xxxa, 16-22

35/2 Now pouert partip felowschep Proverbial 
35/4 Now may pou be certern with owten inquisicroun who hap ben pi ferned frendes Cf Seneca, Ep Mor , 20,7 ' Ob hoc maxıme amanda est paupertas, quia a quo ameris ostendit' Quoted in Fl Doct under 'paupertas' Also in Boethius, De Cons Bk II, Prose vill and in the Roman de la Rose, Chaucer's tr 11 5551-2 'For infortune makith anoon/To knowe thy freendis fro thy foon'

35/5 Flateres wole passen bi $\mathrm{Cf}$ the proverb 'Flatterers haunt not cottages' (Bohn)

35/7 Jogolours of japeres Jugglers had a notonous knack of inviting themselves, 'making an excuse of minstrelsy to obtain hospitality', C Hole, English Sports and Pastımes, London, 1949, p 87

35/15 So dispisith he Crist cf Prov, xvil, 5 'Qui despicit pauperem, exprobat factorı elus', and Prov xxi1, 22 'Non facias violentiam pauperı, quia pauper est'

\section{OF FEBLE FARE}

37/3 Fin fare pin lust The emendation of $p_{i}$ to $p_{i n}$ is suggested by the sense of the corresponding Latin Besides, the form pin in pin fare must mean 'thin' and not 'your' as in all other cases $p i$ is used before consonants

$37 / 7$ pechir prouzd Cf the similar formation 'pot-valiant'

$37 / 9$ Be a fool drunken he is whise jnow he passith in his owne opynyoun a meyster of diuinute Cf Prov xi1, 15 'Via stultı recta in oculis elus' and Bohn 'The way of a fool is right in his own eyes'

37/21 De abstinence of German This may be a reference to Germanus Augustodunum or to Germanus Autessiodurum, both equally famed for their abstemiousness The former was born at Autun about 496 and died in 576 He became bishop of Paris and founded the monastery of St Germain-desPrés His hfe was written by Fortunatus and is printed in Migne, $P L$, $t$ LXXXVIII, col 453-78 The latter was bishop of Auxerre and died in 448 It is this Germain who is often referred to in Middle English literature, as in $A n$ Alphabet of Tales, E E T S O 126, p 235 and Ayenbite of Inwyt, E E T S OS 23, p 190 His life was wntten by Constance de Lyon between 475 and 480 , a 13th-century MS of this is in the B M

37/23 Manye studien seche stories And what is more veyn' This is an example of a translation widely out of its context The corresponding Latin is on p 26, $1127 \mathrm{ff}$

39/3 Podagre The gout was traditionally regarded as caused by a combination of surfeit and sloth Cf Prick of Conscience, 2993 and Capgrave, Chron Rolls, quoted in OED

39/4 De phisisian schal haue pe lesse of pi moneye Allusion to the proverb 'Feed by measure and defy the physician'

39/7 Vnresonable bestes kepe pe mesure pat nature hath tawt hem .cf Samuel Singer, Sprichwörter des Mittelalters, Vol I, p 7 'Das Vieh weisz, wann es heim soll und geht vom Grase weg aber der Narr kennt niemals semes Magens Masz'

39/9 It is wreten pat for surfet many on hath perched Cf Ecclus xxxvu, 34: 'Propter crapulam multı obierunt' 


\section{NOTES}

39/10 Glotenye sleeth mo pan pe sweerd doth. Proverbial, cf. H. Bebel, Proverbia Germanica, ed. W. H. D. Suringar, Leiden, 1879: 'Plures gula quam gladio moriuntur'. Also Wyclif: 'ffor, as clerkes seyn comynly, glotorie slees mo pen dos swerde', Sel. Eng. Works of John Wyclif, Oxford, 1871, Vol. II, Cap xxvi. Also in Bohn: 'Surfeits slay mae than swords'.

39/18 Hungur dispisip no maner of mete. Proverbial and cf. Seneca, Ep.Mor., 119, 4: 'Nihil contemnit esuriens'.

39/19 Dou mayst no betere plesen hym. pan driue hym a wey. Cf. Seneca, Ep.Mor., tr. Loeb ed. 21 : 'The belly... is not a troublesome creditor; you can send it away at small cost...'

39/21 Haue he a mes potage... Cf. the maxim: 'It is better to have a mess of pottage in peace and quiet than a choice of a thousand dishes with a heavy and angry heart' (How the Wise Man Taught his Son, quoted by T. F. Mustanoja, The Good Wife Taught her Daughter, etc., Helsinki 1948, p. 64).

39/22 A feste be pe wombe ful. Possibly an allusion to the proverb: 'Little difference between a feast and a bellyful' (O.D.P.).

39/22 Nature lokep after no delicacies. but pe lippes of lust... Cf. Seneca, Ep.Mor., 17, 3: 'Parvo fames constat, magno fastidium'.

39/29 Haue we our sustinaunce... Cf. I Tim. vi, 8.

39/37 Crisostom seyzt. Not in Petrarch, but cf. St. John Chrysostom, De Compunctione Cordis I, 7: 'Sicut impossibile est, ut ignis inflammetur in aqua: ita impossibile est compunctionem cordis vigere in deliciis. Contraria enim haec sibı sunt invicem, \& peremptona : lla enim mater fletus, haec mater est risus: illa cor constringit, ita dissolvit'. Quoted in Fl.Doct. under 'deliciae'.

41/3 Hony was forbede in pe sacrifice of pe lord. Cf. Leviticus, ii, 11, 12.

41/4 In fugure, Lat. 'in figura', in biblical commentaries the usual way to introduce a symbolical explanation.

41/4 Dat lusti leuyng. Cf. Isidore, Quaestiones in Vetus Testamentum: In Leviticum, Cap. III, (P.L., t. LXXXIII, col. 322): 'Quod autem mel in Dei sacrificio non offertur indicat apud Deum nihil voluptuosum, nihil suave hujus mundi placere, nihilque, quod non habeat mordacis aliquis veritatis'. Also Nicolas de Lyra, Postillae: 'Dulcedo vero mellis significat lasciviam carnis, quae non debet esse in sacrificiis divinis'.

41/10 To wete pi mete in Cristes wondes... For a similarly plastic metaphor cf. The Book of Vices and Virtues, E.E.T.S. O.S. 217, p. 110 where the bread of life, made of our own dough, is said to have been fried and baked in the womb of the Virgin Mary, fried in the pan of the cross and truly fried in Christ's own blood.

41/11 De wateves of Marath, cf. Exodus, xv, 23-25.

41/14 Dis tre be tokenep pe cros of our sauiour... Cf. Nicolas de Lyra, Postillae: 'Moraliter: Per aquas amaras significantur tribulationes vitae praesentis... Per lignum autem intelligitur crux .i. passio Christi, quae si mittatur per fidem charitate formatam in cor hominis repletum aquis tribulationis, vertit illas in dulcedinem per virtutem patientiae \& spem retributionis eternae'. The same commentary is given in the Book of Vices and Virtues, p. 202: 'Pe bitter wateres ben pe tribulacions of pe world; pe tree pat makep hem swete, pat is pe crois pat goddes sone heng on for vs'. 


\section{LANGUAGE}

\section{A. ACCIDENCE}

NOUNS

1. Number. The majority of the nouns conform to the strong masculine type with $\mathrm{pl}$. in -es generally and occasionally $-i s,-s,-u s$ (once): goodes, jueles, tempestis, Hismalitis, condicions, jogolours, labourus. Apart from such plurals as schep, feet, rymmen, uninflected plurals occur after a numeral: seuene sithe, and in manere, sibreden. The weak pl. ending $-e n$ is to be found occasionally: eizen, eyzen, but eres, schuldres. Double plurals: children, childrin, childryn beside childer. OF richesse appears as richees, richesse used as plurals by the side of the double pl. richesses.

2. Gender. Nature and pouerte are referred to by masc. pron. (cf. Mustanoja p. 51). Fortune is referred to by a fem. pron. These are probably degrees of personification.

3. Genitive. The gen. sg. has the ending -es, but -is is also frequent: faderes, sones, worldes, treis, goddis, faderis; -s in bischops, bakers. An uninflected gen. sg. occurs in helle brondes. The ending of the gen. pl. is not distinguished from that of the sg.: gentil mennes children. The OE gen. pl. survives in heuene delices.

\section{A DJECTIVES}

4. The adjective has no distinctive declensional endings. A French pl. in -es is sogetes. The suffixes for the comparative and the superlative are $-e r(e)$ and -est: sekerer, fairere, better(e), feipfullere, greuest.

\section{A D VERBS}

5. By the side of the usual ending $-l i,-l y$ there are $-e s$ endings in 
togederes, vnnepes, ones, twies, ofte tymes, on daies, on nyghtes. Adverbs which originally ended in $-e$ occur in: starith brode, berist heuye, heuy charched, wide open.

\section{PRONOUNS}

6. Personal Pronouns. Nom. forms sg. 1. I, 2. pou, pow, pou3, 3. M. he, F. sche (he), N. it, hit. Oblique forms sg. 1. me, 2. pe (pi), 3. M. him, hym, F. her, here, N. it, hit.

Nom. forms pl. 1. $w e, 2$. ze, 3. $p e i(p e)$.

Oblique forms pl. 1. vs, 2. 3ow, 3. hem (hym).

Northern scho forms are absent, he for she is Southern or extreme East, pe (once only) for they is an unstressed form, $p i$ for thee is a by-form, cf. OED., hit by the side of $i t$ would point to the West Midlands but is also normal in certain areas of the East Midlands. Of the Scand. pronouns $p e i$ is used but for the oblique form hem only occurs.

7. Compound Personal Pronouns. Only the following occur: Sg. 2. pi self, pi silf(f), 3. him self; P1. 3. hem self.

8. Possessive Pronouns. The conjunctive forms are: Sg. 1. mi, $m y, m y n, 2$. $p i, t h i, \not y n n,(p e i)$, the forms with $-n$ being preferred before vowel or $h ; 3$. M. \& N. his, F. her (e). Pl. 1. our $(e)$, ouzr, 2. 3our, 3. her(e), per(e). The disjunctive forms are: Sg. 2. pin. Pl. 3. heren (the $-n$ is added in the South and Midlands on the analogy of $\min$ and $\operatorname{pin}$ ).

9. Demonstrative Pronouns. For the sg. we find pis, pat, such, sech, sich, ilke; for the pl. po, pese, siche. The OE instrumental survives in for $p i$ and in $p e$ followed by the proportional comparative.

10. Interrogative Pronouns. The following occur: who, what. Which is not used nor are the oblique forms of who.

11. Relative Pronouns. wos, whos, whom, wich, pat, (pa). Who is not used as a rel. pron. in the nom. It only occurs in generalising use: who so and in interrogative use.

12. Indefinite Pronouns. al, all(e), any, ony, oni, eche, ilke, no(n), nouzt, no ping, ouzt, owt, oper, sum(me), sum what, what so euer, bobe, nepur.

\section{ARTICLES}

13. Indefinite Article. Before consonants $a$, before vowels and $h$ an; a noper occurs by the side of an oper for 'another'. 
14. Definite Article. $p e$. The $t$ of the earlier form, OE pat an, survives in pe ton.... pe toper.

VERBS

15. Present Indicative. Sg. 1. -e, 2. -est, -ist usually: hatest, metist, but there are a few -es, $-i s$ forms: encresis, pleynes, wantes, calles; 3. usually $-e \bar{p}$, -eth, $-i p,-y p$, -ith, -yth: holdep, happeneth,

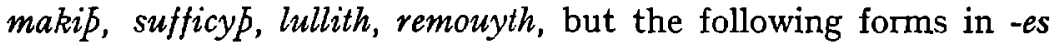
occur: strokes, suffices; -t endings have lift, schewet, seyzt and endingless are grucche and lust, liste (the former might be explained as a subjunctive and the latter are common contractions). Pl. 1.2.3. $-e,-e n$ or endingless: seize, peynten, forfeten, fle. A few hap forms can be explained on syntactical grounds as singulars.

16. Past Indicative. A. OE strong verbs. The past indicative usually shows the normal development from the $\mathrm{OE} \mathrm{sg.} \mathrm{form} \mathrm{of}$ the strong verb: chese, vnbond, fond, brak, drank. There is neither a Northern nor a Western preterite (Wyld, Sh. Hist. § 356). The pl. also shows the normal development from the OE type. Endings: $-e$ or zero for all persons.

B. $\mathrm{OE}$ weak verbs (and imported verbs). Sg. 1. -ed-e, 2. -ed-e: wantede, pleynede, but -ist in schuldist, haddist. 3. -ed-e: preizede.

17. Present Participle. The usual ending is -ing, -yng: filynge, faueringe. The two forms in -ande: induellande, weiferande are clearly substantives.

18. Past Participle. A. of $\mathrm{OE}$ strong verbs. The endings mostly contain an $-n$ : founden, taken, gotyn, goten, born, but some end in $-e$ : bore, forbede, come.

B. of $\mathrm{OE}$ weak verbs and imported verbs. Endings -ed, -id, -ede, -it: aspied, formed, lakkid, helid, schewede, weddit, enduet, offendit, stoppit. The OE prefix ge- has not survived.

19. Infinitive. The most frequent ending is $-e$; also $-e n,-i n$; some have no ending: deliuere, schewe, rise, seken, vsin, sewer, part.

20. Survey of the strong verbs. $(1=$ inf. or related form, $2=$ past. sg., $3=$ past pl., $4=$ past part.)

Class I 1. abide; 4. abiden; 1. driue; 1. bitinge; 1. rise; 4. risen; 1. writith; 4. wreten.

Class II 1. chese; 2. chese; 4. chosen; 1. fle; 1. forbede; 4. forbede. Class III 1. beginnynge; 1. byndere; 2 . vnbond; 4. bounde; 1. climbe; 1. dryngen; 2. drank; 4. drunken; 1. fynde $(n)$; findep; 
2. fond; 3. found; 4. founden; fownden; 1. helpe(n);

1. rennep; 1. voynne; 1. zelden; 1. springen.

Class IV 1. komen, kummep; 3. come; 4. come; 1. bere; 4. bore, born.

Class V 1. biddyngges; 4. beden; 1. breke; 2. brak; 1. ete $(n)$;

1. forzete, forgetynge; 4. forzeten; 1. 3eue, 3iffe; 2. 3af;

4. 3euen; 1. liggeth; 1. se(e); 2. saw; 4. seen, sene;

1. sitten; 2. sat; 1. spekep.

Class VI 1. drawe; 1. farist; 1. lawyng; 1. sleeth; 4. slayn;

1. stondi5; 1. taken; 2. toke; 3. taken; 1. with drawe;

1. withstondip; withstandip.

Class VII 2. blenz; 1. falle; 1. holde; 1. knowe; 1. lete; 1. reden;

2. rede; 4. rad; 1 . walke; 1 . wepith; 4. be hight; 4. beten.

21. Preterite Present Verbs. The following occur:

1. pr. 2 sg. wost; imp. sg. wete; pa. pl. wiste.

2. inf. kun, kunne; pr. 3 sg. kan; pa. pl. couden; pa. 3 ind. kowde.

3. pr. $2 \mathrm{sg}$. derst; pr. $3 \mathrm{sg}$. per (from OE pearf).

4. pr. 1 sg. schal; 2. schalt; 3. schal; pr. pl. schal, schul; pa. 2 sg. schuldest, schuldist; 3 . scholde, schulde; pa. pl. schulde.

5. pr. 2 sg. maist, mayst, mayt, may, mai; 3. may; pl. may; pa. 2 sg. myght; 3. myzt, myght (e), mygth.

6. inf. howen; pa. $3 \mathrm{sg}$. awte.

22. The Verb to be. Present indicative: Sg. 1. ham; 2. art; 3. is. Pl. 1.2.3. be, ben and (less frequently) are, aren, arn. Imp. sg. \& pl. be; past. part. be, ben. Past indicative: Sg. 1. whas; 2. were, where, ware; 3. was. Pl. 1.2.3. were $(n)$; inf. be, bee; pres. subj. sg. 2,3 be.

23. The Verb to have. Present indicative: Sg. 1. haue; 2. hast; 3. hab, hath; pl. hauen; past indicative 2 sg. haddest, haddist; other persons hadde(n). Infinitive haue; past. part. had.

\section{B. PHONOLOGY \\ SOUNDS AND SYMBOIS}

\section{A. The OE and ME Short Vowels}

1. $\mathrm{OE} a$ appears as $a$

I. in closed syllables and open: pat, hadde, faderes, pak, late. There are no $a a$-spellings and no indications of $e$-sounds. 
II. $\mathrm{OE} a+\dot{g}$ (palatal spirant) is spelled ai, ay or ey: fair, fayr, feyre, daies, maiden, slayn, fayn.

2. OE $a$, also ON \& OF $a$, EME $a$

I. EME $a$ in closed syllables and open is represented by $a$ : fals, askyng, asses, talede.

II. Late OE $a$ before a nasal or nasal + cons. (other than $b, d, g$ ) is represented by $a$ in closed syllables and open: man, wanten, many, kam, mad, name, tame, a schamed, pank, drank. pen, penne are frequently found by the side of pan, panne; wen, when, whenne are frequently found by the side of wan, whan, whanne.

III. Before the lengthening groups $n d, n g o$ is generally found, occasionally $a$ : brondes, stonde $b$, withstondip, among, longe $\overline{\text {, }}$ strong; handes, handymaidenes, withstandip.

IV. OE (Angl.) $a$ (WS ea) $+l+$ cons.

(1) before $l+$ cons. (other than $d$ ) $a$ is general: alle, falle, salt.

(2) the Anglian unbroken form appears as o before -ld: olde, holdep, holde, houzshold; euenehelde shows the WS fractured form, unless it is based on the OE sb. eldo.

V. F. a + nasal + cons. produces $a$, au: daunger, chaumbre, seruaunt, perchance.

VI. Late OE $a$ (and EME $a$ ) $+h$ is spelled aw, auz in lawter, tawt, awte, slawter (ON *slahtr), slawt and slauzbe.

VII. OE $a+g$ (voiced back spirant) appears as aw: drawe, lawe (from $\mathrm{ON})$, sawe.

3. $\mathrm{OE} e, \mathrm{EME} e$ appears as $e$ generally

I. in closed syllables before non-lengthening consonant combinations: best, better, betere, helpen, mennes, penken, telle, bedde.

II. In front of lengthening groups: $e, e e$ : sende, seende, ende, zelden, welden, endep.

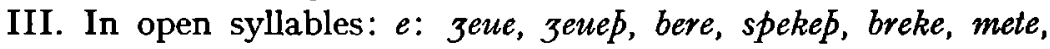
heuye, eten. The inf. ziffe may be due to the 2 nd and 3rd sg. cf. OED. IV. Note the following special cases, where $i$ for $e$ would be Northern or Eastern. (Luick $\$ 379$ and $\S 411$, Anm. 3)

(1) $e$ between $r$ and a dental: verecche.

(2) $e$ between $g$ and a dental: $3^{i s,}$, ${ }^{i t}$, togedere.

(3) before $d$ : stede.

(4) before $n+$ cons.: strengpe; the $i$ in pinke is due to OE pyncan. 
(5) before a palatal: lechery, leccherie, sleknyth, whicch and wycches (OE wecg). OE sēoc appears as sik, seke, siknes, sekenes.

It is clear that the $i$-forms are not dominant, and those with $i$ are quite common in other than Northern areas. Only whicch, wycches (wedge) is not common in the South.

V. ME er appears generally as er: seruaunt, lerne, seruice, zerde, hertes, herbored, werres, ferpinges, fer. -er spellings are more conservative than -ar spellings (Luick $\S 430$ ). Perti and depertip have the contraction sign for -er, but in full departip occurs.

VI. OE $e+\dot{g}$ (palatal spirant) appears as $e i, e i h, e y, e y z: a$ zey, pleyen, seyzeth, seith, weize, weyze, weyith, weihip. OE ongegen appears as azen, azens, a zenes, a zeyn.

VII. In unaccented syllables $y, i, e, u$ occur: certis, certes, gotyn, goten, blessid, sekirli, hungur, comyn, vsin, binyn, komynly, labourus, bittur, opur, wondur, webur, fugure. $e$ and $i$ are most frequent and it should be noted that the sign of contraction for -ur is used, but that the -ur form is not used in full. Similarly the contraction sign for -us is used, but in full -es or $-i$ s are the rule, except in labourus. $e$ and $i$ are characteristic of the North and neighbouring counties (Luick $\S 460,2 \mathrm{a}$ ); $-u \mathrm{r}$ and $-u$ f forms would be typical of the NW Midlands. (Luick $\S 460,2 \mathrm{a}$ ).

VIII. Final $-e$, which would have ceased to be pronounced, was sometimes lost in the spelling: seuer, part (inf.); $e$ is also lost in the inflexional endings of bakers, bischops, jogolours, emperours.

4. OE \& ME $i$

I. OE $i$ appears mostly as $i, y$.

(1) in closed syllables: bringith, brynge, sittip, bitter, lippes, children, springen, widwes, pridde, lift.

(2) in open syllables $e$ is quite frequent: leue, leuynge, ${ }^{1}$ wreten, wete, pedur, hedur, heder too, lemes, sekerer, also in skele (from ON) but $i, y$ in abiden, lyuyng.

(3) before lengthening groups: fynde, childe.

II. OF pretonic $i$ which became stressed in ME is spelled both $e$ and $i$ : cete, vilanye, merour, myrrour, pechir, negardes; desese and profetid show lowering of unstressed $i$; fugure has $u$.

III. ME $i$ from OE $y$ (also 'unfestes' $y$ )

1 In these two forms the $e$ may also derive from io/eo in Anglian. 
(1) in closed syllables: kynne, synne, kynde, pinne, kyndom, firste, kingges, chirche, kisse, knyt, list, birben have $i, y$. The only $e$ forms are werre, werst (the former is Northern cf. OED, also Luick $\$ 286$, Anm. 3) and lest, vb. burpen, lust have $u$.

(2) in open syllables: bisily, besi, juel, merier, bizere, dede (did).

(3) OE mycel, swylc, hwylc appear as meche, sich, sech, such, wich.

(4) in the combination wi the $i$ is rounded to $u$, spelled $o$ : wommen, but wymmen. The aux. vb. will has wele but more commonly wole in the present tense.

(5) OE wyrcan appears once in werkyng, which is probably modelled on the sb. werk. wer forms can be placed in the SE Midlands but can also be Northern.

Generally speaking the $i$ forms are regular. The $e$ forms in III cannot be regarded as evidence for the SE development $y>e$, which is borne out by the fact that also forms with original $i$ (I $+\mathrm{II}$ ) show the development to $e$. The question is complicated by the fact that the $e$ spellings in some cases may represent the lengthened vowel in open syllables. Lowering of $i$ to $e$ is a feature of East Anglia in the 14th century (Luick § 394) or may be due to a more general 15th-century lowering. meche and seche are however typical of the SE Midlands.

5. $\mathrm{OE} \& \mathrm{ME} o$ is generally represented by the spelling $o$

I. in closed syllables: broth, colt, folk, god. When followed by the back spirant $h$ the combination appears as ouz, ow, ough: pouztes, nowt, nouzt, ouzt, owt, brouzt(e), broughte, dowter, wrouzt, fowten.

II. before lengthening groups: hornes, porn.

III. in open syllables: rote, roten, chosen, hope, motes.

6. OE $u$ is usually written $v$ initially, $u, o$ medially: vnder, $v p$, vnnepes, lufly, sum, komep, kummep, hungur, porw; in open syllables: dore, sones. vnloke is a new formation on the analogy of pp. gelocen. The combination -nd does not seem to cause lengthening in wondes. OE $u+g$ (voiced back spirant) appears as ou in foul.

B. The OE \& EME Long Vowels

7. OE $\bar{a}$, EME $\bar{a}$ appears as $o, 00: b o p e, w o s t$, holsom, strokes, old, alone, on, homly, liflode, woo. An a spelling occurs in awte ('ought', vb.), 
which derives from a late $\mathrm{OE}$ form with short $a$. This doublet of ouzte according to Jordan $\S 105$ is restricted to certain areas, mainly the NW Midlands, but is more general in the 15th century (ibid. §287). The form $p a$ (once) is probably nothing else but a slip of the pen for pat.

$\bar{a}+g$ (voiced back spirant) produces ow: owne, howen.

$\bar{a}+w$ produces ow, ouz: knowest, souzle.

8. OE $\bar{a}_{1}$ (from W Gmc $\bar{a}$ )

This is usually represented by $e$. As there are no rhymes the phonetic difference from $e<\overline{\mathscr{e}}_{\mathbf{2}}$ is difficult to establish. Examples: dedes, pere, where, lete, slepynge, speche, schepe, dreden, her.

$\overline{\boldsymbol{e}}_{1}$ before shortening groups shows the usual variation a/e: rede, rad, according to the phase of shortening.

$\overline{\mathbb{e}}_{1}+g$ is represented by $e i$ : keies, but note neper.

ware (pa. subj. $2 \mathrm{sg}$. of to be) is probably from ON váru.

9. $\mathrm{OE} \widetilde{\boldsymbol{e}}_{2}$ (the result of $i$-mutation of $\mathrm{OE} \bar{a}$ )

This is usually represented by e/ee: mene, see, clenly, hele, gredi. When conditions exist for shortening, both $a$ and $e$ occur: clennesse, wrastelinges, fleschli, lasse, lesse, lest (least), lest (OE pjy lāes pe). $\mathrm{OE} \bar{a} n i g$ appears as ony, oni, any.

10. $\mathrm{OE} \bar{e}$ is usually represented as $e$, rarely ee: fele, kepe, also kepte (shortened), mede, seken, spedi, speedful, wepith, feet, swete, weping. OE $p \bar{e}$ appears once as $p i$.

LOE $\bar{e} 3$, êh appear as ei(3), i(3) and igh: hize, higze, lizt, heyzere, hygnesse, heizest, neyzebour, eizen, eyzen, eyze, teyzed, leize, be hight. The $e i$, ey spellings may be traditional or show dissimilation.

11. OE $i$, EME $i$ is usually represented by $i, y$ or $i z$ : driue, risen, nyghtes, lizt, sizt, wynes, whizs, wite. ei for $i$ occurs in the final syllables of Austeyn, gardeines, coseyn and once in pei (OE pin).

12. $\mathrm{OE} \bar{o}$ is usually represented by $o$, oo: oper, moder, goodes, godes, sone. boonde may derive from $\mathrm{ON}$ bonde or from $\mathrm{OE}$ banda, in which case the $o$ is open.

Before shortening groups: blosme; the $u$ in sunnere occurs in the south since 1300 . 
In the unstressed syllables of wisdam, wisdom, praldam $\mathrm{OE} \bar{o}$ appears as $o$ or $a$.

$\mathrm{OE} / \mathrm{ON} \bar{o}+$ back spirant $h$ is found as ow, ouz finally: jnow, poou3, poow, pow. 1 The form pof occurs once.

13. OE $\bar{u} \mathcal{E}$ OF ou are represented by ou, ow, ouz: kowde, couden, pou, houzs, hows, townes, fouzle, flouzres, flowres, mowth, out, ouzt, with ouzten, with owten.

OE $\bar{u}+3$ produces ow: bovee.

14. $\mathrm{OE} \bar{y}$ (also $\mathrm{OE} y$ before lengthening groups) is represented by $i, y$ : fire, whi, pride, thriste (ON prýsta), litil, defilith, myse, kynde, mynde, vnkynde, hidip, filynge.

C. The Short Diphthongs

15. OE ea (of various origin) is usually a: lazeter, laweyng, schat, schal. $e$ occurs in wex.

16. $\mathrm{OE} e o$ is usually represented by $e$, also before original lengthening groups: erpe, fer, heuene, herden. There are no traces of rounding. The group -eoht usually appears as -ight, -izt: right, rizt.

$\mathrm{OE}$ weorc appears as werk; $\mathrm{OE}$ weorold as world, worlde, wordli; weorp in worth, worthi, worschepe, worschipe; OE sweord occurs as sweerd (e).

D. The Long Diphthongs

17. OE $\bar{e} a$ usually appears as $e:$ ere, gret, hened, hed, deth. For the forms of $\mathrm{OE} h \bar{e} a h$ see $10 . \mathrm{OE} \bar{e} a+w$ produces ew: shewe, fewe.

18. OE $\bar{e} 0$ appears as $e, e e:$ theues, freend, frende, frendes, frenchip, depe, ferpinges, tre, sekenes, chese, lemman. èow appears as $u$, euz: trupe, truly, bleuz (OE blēow).

19. OE $i e$ (Anglian $\bar{e}$ ) becomes $e$, ee: nede (sb.); in positions where lengthening is not permanent: $e:$ herd.

1 The forms of 'though' may also derive from OE $p \bar{a} h$. 
E. The Main Consonant Developments

20. OE $c$

Initially before front vowels this is represented by $k: k e p e, k y n d e$, kyng, kynne; $c$ before back vowels: callid, corn, but $k$ is also frequent: kam, kare, katel, kome, kummep. The same in French words: comyn, komynly, cuntre, kuntre, kach, kouzche. $k$ is written before $n$ : knyt, $c$ before all other consonants: clopis, climbe, cloistre, crasche. Voicing is evident in dryngen, ronglen, banges, frangeleyn, a feature of the SE (Luick §369, Jordan § 178, Anm. 2). $A$ st shows loss of $k$.

21. $\mathrm{OE} \dot{c}$

Initially it appears as ch: chirche, childe, but schaf for OE ceaf and crasche for $\mathrm{OF}$ crache.

In medial position ch is usually found: chirche, riches, meche; $\mathrm{OE}$-lice appears as $l i, l y ; \mathrm{OE}$ alc appears as eche, $\mathrm{OE}$ hwylc appears as wich; $\mathrm{OE}$ swylc appears as siche, seche, suche. Partrik (OF pertriz) has $k$ for usual $c h$. See $\S 38$.

22. OE $\dot{c} \dot{c}$ appears as $c c h$, never as $t c h$ : wrecche.

23. OE $s c$ is usually represented by $s c h$, never by ss: schal, schewede, schulde, schort, schap, shap, shetis. $\mathrm{OE}$ ascian appears in askyng, pou ast (pr. sg.); -scipe appears as -schepe, -chip; ME perished, ravished appear as perched, rauyched.

24. $\mathrm{OE} c g$ is unvoiced in whicche, wycches (OE wecg). Liggeth may be from ON liggja.

25. $\mathrm{OE} n g$ is occasionally represented by ngg: biddyngges, typingges, kyngges. OE hläfording appears as lordenes. This change of unstressed -ing to -in is in the 14th century a feature of the North and NMidlands (Jordan $\S 175$ ) but becomes more general in the 15th century (Wyld, Hist. Coll., p. 289).

26. $\mathrm{OE} \dot{g}$ is generally represented as $z$, not $y:$ zeuep, zeuen, zate, zit, zelden, forzete $(n)$, but forgetynge with $g$ from ON $(g)$.

27. OF $g\left(\mathrm{~d}_{3}\right)$ is occasionally represented by ch: charche, chaunchable, purcheth, bondache, larche. 
28. $\mathrm{OE} h(\chi)$. The $\mathrm{OE}$ front and back spirants appear as 3 , gh or $g_{3}$ : neyzebour, nyzt, nyghtis; see also the forms of OE heah under 10. OE porh/ purh appears as porw, purz. In pof $(\chi)$ has been labialized; note the other forms for 'though': poow, pow, poouz. There are abundant examples which suggest that the $O E$ front and back voiceless spirants had disappeared finally and before $t$ :

(1) Spellings showing loss of spirant in medial and final position: dowter, poow, awte, lawyng, lawter, tawt, mowtes.

(2) Inverted spellings with insertion of inorganic 3: lizt, araizeth, souzle, kouzche, slauzpe (beside slawt), ouzt, (out), joize, pouz (OE $p \bar{u}$ ). weihi $\bar{p}$ (weighs) has an $h$, which is typical of the Suffolk area, cf. Bokenham and Lydgate.

29. $\mathrm{OE} h$

The initial aspirate appears as $h:$ hed, hode, but $h$ is sometimes dropped: vntid, enyere and inorganic $h$ is inserted in hesi, ham, howen, Hismalitis and Helyab.

30. OE hw appears as $w h$ but frequently as $w:$ what, when, whanne, while, wheel beside wich, wen, wilis, wan, wos (whose). According to Jordan, $\S 195$ the $w$ spellings belong mainly to the South and SE Midlands. Inverted spellings with wh for $w$ are: whizs, whas, where.

31. $\mathrm{OE} \& \mathrm{ME} d$

In final position $t$ is occasionally found: offendit, stoppit, enduet; $d$ is lost in an (and) and in howsel (household), frenchip and frenschepe.

32. OE $\&$ ME $t$ is sometimes represented by th: mygth, lithlier, lithly, lithsum. These spellings, like the ones in 28, illustrate loss of the spirant. Voicing of $t$, or more probably, inverted spellings illustrating the unvoicing of final $d(\S 31)$ are evident in: seruaund, seruaundes, descounfed and fesaund.

33. $\mathrm{OE} p$ is represented both by $\bar{b}$ and $t h$ : erpe, erthe. $t$ is to be found in final position, representing earlier $\bar{b}$ in schewet, seyzt, lift, mowtes (moths), slawet (sloth), which are dissimilations (Luick $\S 718$ ) and see above $\S 32$.

34. OE $l$ has disappeared in eche, seche, wich; in the unstressed form as (but als); in meche and in wordly. 
35. ME $m$ is lost in supruouzs which may be due to oversight of the abbreviation sign.

36. OE $f$ is always represented as $f$ in initial position. There is no suggestion of voicing. In medial position OE $f$ is usually represented by $u$ : leue, peues, pryuen, but lefe, pefes, prife. Of is assimilated to $a$ following $b$ in $o b$ bondage.

37. $\mathrm{ME} p$. Inorganic $p$ is spelled in solempne, Sampson, redempcion. anemptis.

38. OF $z$

In the (Northern) form partrik (OF perdriz, pertriz) the change of $-r i z$ to - rich is notable and so is the change of -rich to -rik in Northern English, comparable to hevenrik, kingrik, etc. See OED s.v. partridge.

\section{VOCABULARY}

The Scandinavian element in the vocabulary is amply represented but the nature of the words excludes direct Northern influence. Most of them were generally adopted in the Midlands and have survived in the modern standard language, e.g. angry, banges, birthe, bonde, bope, bren, calles, dize, felaw, felow, forgetynge, happe, gest, skele, triste, semely, pral, priste, pryuen, wante, werse. On the other hand the 'opportunities missed' where Scandinavian equivalents were available are numerous as in alwey, azen, blosme, chirche, fere, ziftes, zeuen, her, reved, seke. Definitely Northern forms are wand, sleknyth, partrik, werre, pof and rongle 'wrinkle'; the latter word occurs also e.g. in the Prick of Conscience as rounclen where a Southern transcript has wyrlynkeleth (cf. Kaiser, Medieval English, p. 237).

That the language used by the author was modern and up to date is attested by the fact that a considerable part of the vocabularyeither in all or in particular meanings - is first recorded in OED and MMED $^{1}$ in the last 20 or 30 years of the 14 th century. Many of these are first recorded from Wyclif's works, such as contemptible, sufficient, ruinouzs, odiouzs, nouelte, iniurye, necessarye, dispose, proceden, infames, ascende, ocasion, sauery, ierarchies, compellith, encrese,

1 The testimony of the MMED could only be used up to the letter $h$. 
magnified, progeny, forfend, dyuors, corupt, pp., inquisicioun, knowlech 'acquaintance', opinions 'rumours'; others are first recorded from Chaucer's works as condicioun, consideracioun, constreine, denyed, comendable, frenetik, constaunt, acceptable, arest 'check', famyliar 'of one's household', oppressed, toty, mutacions; and from Trevisa's translation of De Proprietatibus Rerum, such as apt, expedient, discharched, impediment.

A few words and phrases are not recorded in OED and MMED in the senses employed in our text: mulori 'legitimate wedlock', brefnes (of size), induellande (lit. inhabitants), binyn (sb.), me heuyep (impersonal), in no poynt 'in no sense', may 'like'.

The following words are recorded in OED \& MMED with earliest dates later than 1400 (the earliest OED record of the meanings relevant to our text follows between brackets): seuer 'distinguish' (1420), enduet (1447, MMED 1402), altitude 'height' (1420), remocion (1449), myraculusly (1494), inhibete 'forbid' (1460), naturel 'by nature, by birth' (1420), legale 'before the law' (1610), affluens (1447, MMED 1390), jongkerie (1449), mes potage (14 ...), delicacies (c. 1450, MMED c. 1410), powder box (1403), suptuouzs (1485), honoure 'adorn' (1528), medle 'mixture' (1440), debilite 'physical weakness' (1484, MMED ?a 1425), clips 'deprivation' (1598), dignify (1526, MMED 1449), sessiounes 'conferences' (1444), herden (adj.) (1522), professioun 'learned profession' (1541).

Some of these, but by no means all, are translations from the Latin of Petrarch. The testimony of the OED in this respect, though naturally inconclusive, suggests that the author, not in the last place through his knowledge of Latin, employed a modern vocabulary and had an alert eye for new connotations of words (cf. also the notes on style for his use of puns). On the other hand the nature of this last group of words does not necessarily mark him an innovator or a pioneer in the use of language. His interest is in pithy expressions and more typical of his use of language are perhaps the following popular combinations which are not recorded in the standard dictionaries: goddisbondes, beli seruaunt and pechir prouzd.

\section{LOCALIZATION OF THE DIALECT}

After the foregoing analysis of the accidence, the phonology and the vocabulary of the Dialogue we may attempt to determine the dialect 
boundaries of our text. With the aid of the Middle English Dialect map by Moore, Meech $\&$ Whitehall we arrive at the following conclusions:

1. OE $\bar{a}$ is represented by $o(o)$. This points to a region South of the Humber.

2. The pr. pl. ends in $-e(n)$. This lowers the Northern boundary to the middle of Lincolnshire.

3. The pr. sg. ending -eth (rarely -es) rules out the NE Midlands and the NW Midlands.

4. Shal and hem are used to the exclusion of sal and theim, which again excludes the NE Midlands.

5. The absence of $v$ for initial $f$ excludes the South, South West and South East.

6. The preponderance of $i$ forms for $\mathrm{OE} y$ likewise narrows the area in from the West as does the man/mon line.

7. The endings of the pres. part. (generally $-y n g$, -ing with only two -ande forms) again rule out the North but the few -ande forms do not necessarily rule out influence from the extreme East (cf. Moore, etc., p. 18).

8. Oakden's dialect test (MMED, Plan, p. 11) rules out the North of Norfolk, the North of Cambridgeshire and Rutland.

Therefore, the general complexion of the language is that of an East Midland dialect. The very few traces of possible Western influence would suggest that the district was far removed from the Western border of the East Midlands. On the other hand the small number of Scandinavian words and the fact that these are nearly all common words would suggest a district removed from the Northern areas, a fact which is underlined by the comparatively few Northern forms. Even so we are left with a rather large tract. Within this area of the East Midlands it is very difficult to localize the dialect of a text with anything like precision on linguistic evidence only. In the 14th century there developed in the central area of the East Midlands a written standard ${ }^{1}$ which, while based on the dialects of the Central Midland counties, especially Northamptonshire, Huntingdonshire and Bedfordshire, presented a type of language which was less obviously dialectal. This written standard was adopted for a large body of writings, religious as well as secular and copied in outlying districts where it can

1 Cf. M. L. Samuels, 'Some Applications of Middle English Dialectology', English Studies, Vol. XLIV, No. 2, April 1963, pp. 81-94. 
never have corresponded to the spoken dialect. Because of this degree of standardization the many slightly varying forms of this Midland Standard cannot readily be assigned to specific areas.

One way to obviate this difficulty is a closer examination of spelling variants. Professor McIntosh and Professor Samuels have stressed the importance of spelling variants as dialect criteria. ${ }^{1}$ Even when orthographic variation does not give a clue to phonetic variation, when plotted on a map these variations show regional distribution. In response to a request for advice, Professor McIntosh and Professor Samuels at first localized the text on the border between Hunts and Ely, a little North of the Cambridgeshire border, but some odd-looking features remained which suggested scribal mixture. Forms and spellings which are not typical of the Central Midland Standard are seche, meche, hym (for them), he (for she), affter, forme (from), final -et for -ed, porw, the frequency of $e$ forms in $\operatorname{pen}(n e)$, wen(ne). The form weihip (weighs) with an $h$ is typical of Suffolk, being paralleled by forms like neyhyn (approach), syhyn (sigh) in Bokenham (E.E.T.S. O.S. 206, especially scribe C). These forms can all be fitted into the Ipswich area of Suffolk.

The Suffolk characteristics find further confirmation from the rest of the scribe's work in the MS. The Tretis on Mayndenhod has occasionally such forms as hee (she), hundert, heere (their), weche, seche; Benjamin Minor has feer (fire), meche, mechil, mekil, crihep, myzthe, pres. part. in -ande, -inde, -ende by the side of usual -inge; the Cloud of Unknowing has ecche, wicche with two $c$ s (which do not derive from its exemplar, MS Harley 674, see below). These forms are equally characteristic of the Suffolk area. Spellings showing confusion between $t, t h$ and $h t$ as exemplified in myzth (might), mythtes (powers) in the Cloud and slaret (sloth), schereet (shows), seyzt (says), lithly (lightly), lithsum (pleasant) in the Dialogue are frequent in East Anglia (e.g. in The Book of Margery Kempe and in A Litil Tretys of the Suffolk writer Lavynham and in the works of Capgrave. The unvoicing of $\left(d_{3}\right)$ in charche, chaunchable, bondache, larche, etc., is also frequent in East Anglia, perhaps more in Norfolk than in Suffolk (Promptorium Parvulorum, Capgrave and the Paston letters).

The insertion of 3 in words like souzle, ouzre, houzs, lizf, etc.,

1 Cf. Angus McIntosh, 'The Analysis of Written Middle English', TPS, 1956, pp. 26-55, and M. L. Samuels $o p$. cit 
however, which is regular in all the MS, is not a typical feature of either 'Central Midland Standard' or the Suffolk dialect, but occurs mainly in a restricted area on the border of S. Beds., N. Bucks., and $\mathrm{N}$. Herts. It is not impossible, however, that this spelling habit, though commonest in the above surroundings, is occasionally adopted elsewhere and the fact that there are traces of it in other SE texts makes it reasonable for the Suffolk layer. The large percentage of hit forms by the side of $i t$ is typical of the West Midlands but is also normal in East Suffolk.

Other non-Central Midland Standard ingredients are pof, ilke, werre, partrik, rongle (vb. wrinkle), wand, pres. part. in -ande ${ }^{1}$ and the sprinkling of -es forms in the 3rd person sg. of the present. These features are too far North to fit a SEM cast of language. This makes the text look obviously non-homogeneous and there may be various layers, perhaps three or more, resulting from the imperfect scribal adaptation of the original copy. ${ }^{2}$

In such cases it is hard to sort out the various layers, especially in a prose text where there are no rhymes which might give clues to the original language and later accretions. Some help is however afforded by the fact that the version of the Cloud of Unknowing in our MS has a close connection with that in MS Harley 674. Miss Hodgson in her collation of the two versions in the above MSS has shown that the former is based on the latter and is possibly a direct copy from it (E.E.T.S. 218, p. xx).

It is a well-known fact that medieval copyists often 'translated' the dialects of their originals into their own idiom, but it is obvious that traces of their originals should remain evident. A comparison of the Cloud-version of MS Ii.VI.39 with that of MS Harley 674 shows that a number of forms that do not fit in with our scribe's usage in the rest of the MS can be explained from the text he was copying. ${ }^{3}$ Forms like

1 -ande is also possible in Suffolk

2 That our text is a copy is also evident from scribal mistakes such as repetitions of words and sentences, spellings confused with those of the next word, often through homoeoteleuton, letters mistaken or omitted through misunderstanding of the meaning of the sentence See footnotes to the text

3 Miss Hodgson's careful statement does not exclude the possibility that there is an intermediate stage of copying between the two MSS If so, this does not affect our argument that the Cloud was-at one stage-copied by a Suffolk scribe The odds are that if this intermediate copy existed, it must have faith- 
soche, moche(l), silue, fiier, fijr, fiir, peese in our MS can all be traced back to the scribe's exemplar in Harley 674. This indicates that the scribe did not consistently supplant the forms of his original by his own. The unique form $b e p$ (for usual ben, occasional aren) in Harley 674 is taken over and constitutes also the only $b e p$ form in Ii.VI.39. On the other hand he occasionally replaces soche by seche, mochel by meche, owne by ouzne, -ing by -inde, fiir by feer, charge by charche, chirche by cherche, $i(l) c h e$ by $e(c) c h e$, skile by skele, miztes by mythtes, mizt by myzth. ${ }^{1}$ These forms conform with his practice in the rest of the MS.

Taken as a whole the text of the Cloud in Ii.VI.39 represents a more $\mathrm{SE}$ dialect than its original (which Professor McIntosh is inclined to assign to Rutland). If one 'peels off' the features that are regularly changed in our scribe's version of the Cloud one finds that they can all be fitted into Suffolk.

As to the other treatises there is no indication that the Suffolk characteristics displayed in them are due to the original versions. ${ }^{2}$ It would seem then that the Suffolk characteristics constitute the top layer which was imposed on all the treatises whatever their original provenance.

On balance, the text of the Dralogue as it stands is not very tractable from a dialectal point of view. Apart from the Suffolk overlay one is left first with the additional features of SW Ely. It is hard to say whether this constitutes an extra layer due to an intermediate stage of copying or whether one has a case here of a scribe who in the main

fully transmitted the features of Harley 674, since they can still be traced in our MS The other possibility that the intermediate copy already contaned the Suffolk characteristics, which were subsequently taken over by our scribe, does not affect this argument either

1 See also Miss Hodgson's analysis of the language of MS Harley 674 with notes on the variant forms, op crt, $\mathrm{pp}$ xxvil-1

2 As long as one knows nothing of the versions which the copyist had in front of him, it is difficult to say anything definite None of the treatises, however, seem to have relations with the South East The Cloud in Harley 674 is NEM, the Sermon of St Augustine is related to the Wycliffite Bible translations The only other MS containing the poem on the sixteen points of charity, Lambeth 853 , is placed by Professor McIntosh near Hunts and the Cambridge border $A$ tretts of mayndenhod occurs also in MS It VI 55, which is a standard Midland text Benjamin Minor in our MS is closest related with the version in Westminster School Library MS 3 which is probably from the Peterborough area 
adhered to the 'Central Midland Standard' type but occasionally introduced forms from his own peripheral dialect. Secondly, the occasional -es endings for the 3rd. sg. present, pof, ilke, werre, partrik, rongle and wand are peculiar to the Dialogue and are not found in the other treatises in the MS. As to the presence of these few Northern forms one can only speculate but not say much that is definite. It is just conceivable that a scribe who was used to copying Northern or $\mathrm{N}$. Midland texts, might get into the habit of using some of the forms even when they were not in his exemplar. But the normal and usual interpretation is that they are from an earlier stage of copying, since then practically erased by subsequent stages. If any guess should be made as to the original language of the Dialogue, the above forms might point to an obscured N. Midland layer.

\section{E. STYLE AND PROVERBS}

In comparison with Petrarch's Latin prose style, which presents various types of rhetorical embellishment, the style of the English treatise is simple and straightforward. A comparison of the following passages will bear this out:

Carebis solitis opibus: simulque solitis muribus ac furibus et protervis servis: hisque quibus solent abundare divitie: fictis amicitiis: sequacibus atque tenacibus parasitis: totoque illo grege domestico arridentium tibi teque ridentium atque rodentium $34 / 41 \mathrm{ff}$.

with its display in a single sentence of homoeoteleuton, rhyme, alliteration and paranomasia; where the English paraphrase runs:

Richesse taken neuere here leue be per one. for myse $\&$ mowtes folwen hem euere. Frowardnesse $\&$ falsnes of seruauntes gon with hem $33 / 16$.

Here the only rhetorical figure is that of alliteration. Nor is the following type of wordplay (paranomasia) imitated:

Innumerabiles in discrimen: fere omnes in crimen trahit $2 / 25$

or Petrarch's punning on nitor and nitere in dialogue I, 4/29ff.

The text, as one might expect from the subject-matter, is considerably less 'encrusted with omament' than some other late medieval texts of which $A$ Talking of the Love of God is a striking example. Yet there are certain stylistic features which suggest that the author was 
conscious of a similar rhetorical tradition. His style need not have been directly influenced by his Latin original but is based on a long-standing tradition of devotional writing, in Latin as well as in the vernaculars, which favoured a highly ingenious prose rhetoric, based mainly on antithesis and balance of phrasing, the use of alliteration, rhyme and punning and various other formal devices. Medieval Latin epistolary style was fraught with these embellishments, but also devotional literature used them extensively. The Collects of the Mass infused the minds of the clerics with the cursus patterns and the rhythmic flow of the Latin examples. The desire to reproduce these effects in English had been influential in England since the days of Aelfric. There was, then, extant a native tradition of devotional rhetoric, which derived ultimately from Latin and which kept constantly in touch with the Latin patterns.

Here follows a discussion of the most obvious figures:

Alliteration forms a marked feature of the style; in most cases it is independent of the Latin example-though Petrarch, too, makes frequent use of alliteration-, as in the following instances:

Whanne pei of borwed her. feynen hem hornes panne falle pei tro fayrnesse to pe $l$ iknesse of $L$ ucifer. \& forfeten a 3 en pe lore of Petir \& Paule 5/1.

for which there is no Latin original.

For with pe lasse labour maist pou be maister $7 / 21$.

Doow siknes be non lithsum fere: a feipfullere felow found pou neuere... 7/26. ...pe lippes of lust be so likerouzs him liste not euen soupe... 39/23.

Seyntes lete but lizt be bodili bewte $3 / 27$.

The effect of alliteration is strengthened when the alliterating syllables coincide with the strong stresses of a cadence form, ${ }^{1}$ as in :

pe herytage of heuene (planus) 19/20.

How precious a juel (planus) pat pi souzle is prouep pi redempcion (tardus) $\quad 9 / 18$. wanne he findep him fawty (planus) $9 / 8$.

1 On Petrarch's use of the cursus see G. Lindholm, Studien zum mittellateinischen Prosarhythmus. Studia Latina Stockholmiensia X, Stockholm, 1963, pp. 88-110. On the influence of the Latin cursus forms on English prose and the manner of adaptation to the English language see M. W. Croll, 'The Cadence of English Oratorical Prose', Studies in Philology, XVI (1919), 1-55. Also N. R. Tempest, The Rhythm of English Prose, Cambridge, 1930. 
Alliteration also serves to reinforce other figures of style, as in the following instance of antuthesis:

Fro $d$ epe rotes and derke proceden deleitable braunches $13 / 5$

Similarly alliteration serves to add force to a metaphor:

Manye hauen rolfull chosen pouerte to peramour 33/9

Parallelısm is marked by alliteration in:

As often sik as often sumned . $7 / 28$

In the following Bible quotations alliteration is used:

Be ze seruauntes sogetes to zour souereynes $23 / 6$

where the Wycliffite version (L.V.) has:

Servauntis, be 3 e sugetis in al drede to lordis

Similarly:

Haue we our sustinaunce $\&$ clopes to kouer vs hold we vs content $39 / 29$

where the Wycliffite version (L.V.) has:

But we hauynge foodis, and with what thingus we schulen be hilid, be we pared with these thingis

Rhyme and homoeoteleuton, frequently employed in Petrarch's text, do not occur to any marked extent. But note:

3if hit be an instrument sufficient to serue pe souzle $7 / 17$

bestes kepe pe mesure pat nature hath tawt hem 39/7

to wete pi mete in Cristes wondes $41 / 10$

pe bitter galle pat pou tasted in pr passioun is ful fer fro pe mynde of a likerous glotoun $41 / 7$

for pat pou wantes pi del $\imath$ t he dede it for pi prof $2 z^{t} \quad 3 / 3$

Most of these instances are debatable and moreover only a greater frequency would convince us that the author seriously attempted to imitate his Latin example.

More striking is the figure of antithesis (often combined with balanced sentence-members). It may be noted that the frequency of this figure 


\section{LA N GUAGE}

is to be expected in a treatise which sets out to explain that things are the opposite of what they seem to be.

Bou mayst no betere plesen hym. pan driue hym a wey $39 / 19$.

Pe dymmere pat pe fame of pi cuntre is: pe lithlier may pe bryztnesse of pi name be sene $11 / 8$.

Fro depe rotes and derke proceden deleitable braunches $13 / 5$.

Often tymes grete treis springen vp in streyt gardeines $11 / 16$.

To be riche is solempne: but to be pore is more sekur $27 / 31$.

For pe to serue: is to regne 23/16

...porw pi true seruise: pou schalt be weddit to liberte $25 / 20$

Such pointed epigrams as in the following oxymoron of Petrarch are beyond the English adapter:

Multis serva libertas: multis est libera servitus $20 / 44$.

Isocolon (parallelism of sentence-members nearly equal in length) occurs regularly: ${ }^{1}$

Lufly schap of body: is lemman to lechery $3 / 26$.

As pou encresis in age: encrese in vertues $5 / 32$.

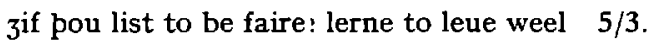

As pou art pore of money! be pore of spiryzt 35/25.

Epanados (free repetition of words sometimes with slightly varying implications [antanaclasis]).

... poruz a fals tale of his fals lady, be cause pat he nolde be fals to his maister he was falsly en presound 25/26.

Who so dispisith pe pore for non opur cause but for pei be pore: in pat alle pore he dispisip. \& so dispisith he Crist pat was most pore (etc.) 35/13.

.. \& poow pe comen lawe inhibete pe to take holy orderes. in holi wryt is non obstacle pen pouz may be an holy lyuere $19 / 17$.

Polyptoton (the appearance of the same word-base in various forms)

...feterid with pe bond of bondage 21/9.

... to be pi lordes lord $21 / 11$.

...he unbond his byndere $25 / 7$.

1 For the function of the inverted semicolon cf. p. [13]. 


\section{IANG UAGE}

Antimetabole (epigrammatic reciprocal change of a sentence resulting in an inverted order of repeated words) occurs principally, it should be noted, in proverbs and epigrams borrowed from other sources. The essence of the figure consists in the cleverly contrasted meaning.

Place makep no man holy: but man makep holy place 11/23.

...per is no kyng but be kam of seruauntes neper no seruaunt but he kam of kynges $15 / 15$.

...deformite of bodi defilith not pe souzle. but pe fairnes of pe souzle honoureth pe body $3 / 22$.

Bonde body \& free souzle a corden wel jnow to gedere. but bonde souzle \& free body pryuen neuer wele 25/9.

Petrarch delights in 'sententiae a verbo', in using words with overtones which borrow allusive force from the situation. ${ }^{1}$ The English author occasionally attempts to do the same. Thus in the following instances a word which is used by Aduersite in its obvious sense is taken up by Resoun to have some special aptitude in his argument (amphibolia).

Aduersite: I ham oppressid with pouerte $27 / 1$.

Resoun: ... how scholde pouerte priste pe doun. sythen euere pe porere pou art: pe lesse art pou charched $27 / 21$.

(In the Catholicon Anglicum ${ }^{2}$ oppressus is given as the Latin equivalent of thriste downe).

This type of word-play can degenerate into the 'beating thin of an idea'. A witticism very similar to the one just quoted is served up again in 23/29:

Resoun: And how mayt pou pleyne pe pat pou art heuy charched sipthen pou gost half void?

and again in $27 / 26$ :

...to pleyne pe pat pou berest heuye : wanne pou berist litil. is a wrong formed pleynt.

1 A striking example of this type of word-play is afforded by Seneca in Naturales Quaestiones $\mathrm{I} .16$ when, after describing a mirror in which all objects were enormously magnified, Seneca says that its disreputable owner ought to have been put to death in front of it-so as to suffer a more than ordinary death. Cf. W. C. Summers, Select Letters of Seneca, London 1910, p. LXXV.

${ }^{2}$ E.E.T.S. O.S. 75, p. 386. 


\section{A N G U A GE}

\section{Similarly in the next two quotations:}

...Paule pe apostle wrytip. pat pe flesch is rebel a $z$ ens his lord pe spirit. Sithen pe bodi penne is pi famyliar enemye. his debilite dop meche for pe. For with pe lasse labour maist pou be maister $7 / 19$.

Wilis pe flesch \& pe spirit wrastlen to gedere: hinderyng of pe ton is forthing of pe topere. Fauere pe betere 9/1.

The twofold sense of to honour ('adorn' and 'honour') is alluded to in:

Aduersite: Whi was I born so vnschaply? Resoun: For pou schuldest honoure pi self with sich a beuzte pat schulde kepe pe fair $3 / 12$.

The various senses of 'goods' are exploited in:

Aduersite: Fortune hath spoiled me of my goodes. Resoun: A comen opinioun. pat fals is hap deceyued pe... 3 if a man wante richesses: pei seize he hath no good. But wisdam redeth vs a noper lessoun: per ben pre manere of goodes. goodes of grace. of nature. \& of fortune. De laste hap lest of goodnesse... etc. $31 / 24$.

Note also the following instance with its differing applications of related words:

Aduersite: Mi desir were to be heyzere. Resoun: As pou encresis in age: encrese in vertues. panne pou schalt be verily more. \& welde a worthi hygnesse 5/31.

\section{Cf. Petrarch:}

Dolor. Vellem esse altior et maior. Ratio. Assurge animo cresce virtutibus: maior eris atque altior. Hoc utilius hoc facilius incrementum 4/23.

\section{Proverbs and pithy sayings}

Proverbs are a frequently used device in moralistic and monitory literature. To Aristotle the proverb was a recommended rhetorical figure comparable in effect to the simile, the metaphor and the hyperbole. Moreover the proverb was regarded as an authority by virtue of its being universally known and 'beyond the reach of corruption'. ${ }^{1}$ To begin or end a poem with a proverb is one of the methods recognized and approved by the medieval rhetoricians. ${ }^{2}$

1 Cf. Aristotle, Rhetoric III, xi and I, xv, transl. by Th. Buckley, Bohn's Classical Library (1851) p. 241 and 96.

2 C. S. Baldwin, Medieval Rhetoric and Poetic (to 1400), Gloucester, Mass., 1959, p. 180. 
Unlike the more modern antiquarian interest in 'the old proverb', in the Middle Ages the prime use of the proverb was for didactic purposes as in Cato's Distıchs, The Proverbs of Alfred, How the Wise Man Taught his Son and How the Good Wife Taught her Daughter. In Chaucer's Tale of Melibeus it is evident how proverbs and maxims could be adduced as evidence to corroborate one's thesis. A proverb was a ready-made epigram, a valuable conclusion to one's argument. In our present text 'alle is wel pat endep wel' is referred to as an olde prouerbe, 'litil katel: litil kare' as an olde sawe, while 'bonde body $\&$ free souzle a corden wel jnow togedere. but bonde souzle $\mathcal{E}$ free body pryuen neuer wele' is referred to as a schort word. These are, however, no strict distinctions; from the various references to proverbs ${ }^{1}$ it would seem that in the Middle Ages no serious attempt was made to distinguish the 'true' proverb from the adage, the epigram or the 'sententia'. Many medieval works have titles that suggest genuine collections of proverbs, but are often misleading as to therr real contents. Any one turning to the Proverbs of Alfred for the study of proverbs will be disappointed.

The medieval conception would include under the term 'proverb' all quotations from the scriptures (esp. the Book of Proverbs and Ecclesiasticus), the Fathers, in fact any quotation from a patristic or classical authority. As Baldwin shows, there were classified lists of proverbs extant for use in dictamen. ${ }^{2}$ Compilations and florilegia of memorable sayings equally served the author who was at pains to give point or weight to his argument. For the rest it is very difficult to tell 'popular' proverbs from 'learned' proverbs. What at first sight looks like a genuine popular proverb can often be traced back to some 'learned' source and its popularity may hence be due to its long standing 'learned' use through frequent quotation. But even then the question often remains whether in some cases the learned authority might not have borrowed from the popular tradition. ${ }^{3}$

The following quotations may illustrate the point that many 'proverbs' and proverbial sayings in this treatise belong to the tradition of devotional writing leaning on the Scriptures, the Fathers and the classical authors familiar to the Middle Ages.

1 Other terms used in Middle English are 'byword', 'an old clerkes sawe', 'an old sard saw' or 'a commune sawe'.

2 op cit $\mathrm{p} 191$

s On this problem sec A Taylor, The Proverb, Cambridge Mass, 1931, pp. $3 \mathrm{ff}$. 


\section{A NG UAGE}

Dere is non bed soft to a seke man 27/29 (Seneca) ${ }^{1}$

Per is no kyng but he kam of seruauntes neper no seruaunt but he kam of kynges $15 / 15$ (Plato)

Place makep no man holy but man makep holy place 11/22 (classical)

Not he pat lest hap' but he pat most coueitep' is most pore 33/6 (Seneca)

A bittur drinke purcheth wikkıd humour 9/10 (St Gregory)

Deformite of bodi defilith not pe souzle but pe farnes of pe souzle honoureth pe body 3/22 (Seneca)

What forbedeth a meche man to inhabit a low hows? So may a gret souzle wonen in a schort body $5 / 15 \quad$ (Seneca)

Greuous infurmite makip sober souzle $9 / 6$ (biblical)

Vertu in infirmite is perfitly mad 9/25 (biblical)

Nede may sone be riche jnow but couetise seyzeth neuer hoo $33 / 4$ (Seneca)

Als meche as he wolde haue' as meche him faylith 33/5 (Horace)

Farre fetoured bodi $\mathcal{E}$ clennesse of souzle selden nestele pei to gedere $3 / 9$ (Juvenal)

Der is no ping in erpe don with ouzten cause 23/1 (biblical)

Hungur dispisip no maner of mete $39 / 18$ (Seneca)

Fro pe may fortune nouzt bere' but pat sche may bringe to pe $31 / 30$ (Seneca)

The thoroughness with which proverbial lore permeates this popular style is even more evident from the fact that the author sometimes alludes to a proverb without actually mentioning it or provides a vanant, as in:

Haue pe seruaunt of god hungur $\varepsilon$ salt' he wol not be angry for oper sause fallyth 39/33 (Hunger is the best sauce)

Be a fool drunken he is whise jnow he passith in his owne opynyoun a meyster of diuinite 37/9 (A fool is ever wise to his own thinking)

Affter pe frute is pat is lengest abiden is a tree demed good or badde $15 / 10$ (A tree is known by its fruit)

Haue he a mes potage 6 stor of houzse him pinkith he hath a feste be pe wombe ful 39/21 (Little difference between a feast and a bellyful, ODP 1659 ${ }^{2}$ )

1 For more specific references see the Notes It is by no means implied that the source indicated between brackets is the only source or even the one which the author used

Many but by no means all of these proverbs are of course to be found in Petrarch

2 The dates refer to the first record in ODP 


\section{LANGUAGE}

Were pouerte $\&$ paciens wonen to gedere: pere is rich pouert 33/19 (Patience with poverty is all a poor man's remedy)

In the discussion of the value of beauty:

Litil worth is pe blosme: but ony frute folwe 3/27 (Beauty is but a blossom, $O D P$ 1616)

In the discussion of gluttony:

\& for to seyze schortly. pe phisisian schal have pe lesse of pi moneye $39 / 4$ (Feed by measure and defy the physician, ODP 1550)

In the discussion of poverty:

Flateres wole passen bi $35 / 5$ (Flatterers haunt not cottages)

A fyn sweerde is ofte houzsed in a roten schepe $5 / 35$

This may be a deliberate reversal of the familiar proverb: $A$ leaden sword in an ivory sheath on the model of e.g. A strong souzle is ofte herbored in a feble bodi $5 / 36$.

In the discussion of servitude:

Trupe may not be slayn. poow it be beten 25/28 (truth may be blamed but cannot be shamed, ODP 1450)

Goddis grace (is) ner pan pe bischops dole $31 / 23$ (ct. God's help is nearer than the fair even, $O D P 1641$, and variants)

Other proverbs and proverbial phrases are:

Eche ping hath his mesure $7 / 11$

cf. There is a measure in all things, ODP 1380.

A strong souzle is ofte herbored in a feble bodi $5 / 36$

cf. A little body often harbours a great soul, ODP 1611 and see note to $5 / 36$.

Often tymes grete treis springen vp in streyt gardeines $11 / 16$

Alle is wel pat endep wel $25 / 22$

In derk place. litil lizt is sone aspied $11 / 9$

Pouert partip felowschep $35 / 2$

To souzpe of pe same broth $37 / 22$

How so euere pe world waggeth pou mayt not falle fer $23 / 21$ 
cf. Let the world wag, ODP 1529 and Thus fareth the world that one goeth up and another goeth down, ODP 1481.

Wel worth pe wand pat makip wilde childer tame $9 / 10$

Glotenye sleeth mo pan pe sweerd doth $39 / 10$

This latter proverb is recorded earliest in ODP 1509, but it is found, apart from this instance, e.g. in Wyclif; see note to 39/10. It would seem that an early record for a proverb in English very often depends on an early rendering from Latin. Thus in our text the proverb: Fro pe may fortune nouzt bere: but pat sche may bringe to pe 31/30 is a reference to Seneca: Nihil eripit fortuna nisi quod dedit. The English version: Fortune can take from us nothing but what she gave us, is first recorded in ODP 1732.

In the dialogue Of Siknes $9 / 6 \mathrm{ff}$. there is a whole string of proverbs used by way of arguments. Such passages are reminiscent of the set exercises of the medieval schools in which proverbs were used as verbal ammunition or as 'authorities' to prove an argument.

Sometimes a proverb is used to curtail the argument of the longer Latin text as in: Litil katel: litil kare, where the Latin has: Iam nullus tibi superbie locus erit: nec invidie: nec damnis insignibus: nec damnorum metui: nec suspitionibus mille: nec insidiis: nec nausee, nec podagre divitum hospitibus: Quibus exclusis habitatura latius tecum quies et tranquillitas et virtus. Similarly in: Litil cors: litil cariage. pou art no burpen to pi self, where the Latin has: Quis unquam de exigua conquestus est sarcina? Justa hercle dolendi causa quod non pressus mole corporea sed indutus: neque ipse tibi tedio sed usui sis.

The debate on the value of noble birth is summed up in the following epigram: Deme now wepur is fairere to zeue cleernesse with pe sunne. or lizt to borwe with pe mone, where the Latin has: Vides ne igitur quanta tibi nove laudis occasio data est: Nobilem per te fieri: et nobilitatem dare non accipere. Dabis hoc posteris tuis ut nobiles nascantur: quod parentes tibi non dederunt tui. Plus est multo nobilitatem fundare quam fundatam $a b$ aliis invenisse.

These proverbs and terse sayings are but one exponent of a more general characteristic to find concrete and visual, and always easily grasped, equivalents for abstract thought, as one might expect in popular instruction. The author avoids abstract reasoning; his thought crystallizes at once into images. Thus he frequently employs personifications: 
...conseille with pi stomak $39 / 1$

...contricion is modur of weping $41 / 2$

...hauen ioifulli chosen pouerte to peramour $33 / 9$

Wel I haue aspied. pat pou \& lust wolde kisse. were it not pat pouerte kepith zow on sundur $39 / 15$

...let hope be pi mynstrelle $25 / 13$

Wilis pe flesch \& pe spirit wrastlen to gedere: hynderyng of pe ton is forthing of pe topere $9 / 1$

... kach hope be pe skirt $31 / 19$

While wele and woo pleyen at pe balle. nepur of hem kan holde longe pe balle stille. but hedur and pedur it gop contynuely $31 / 20$

This liking for concrete expressions is also evident in the graphic circumlocution of what in a style less bent on embellishment might be expressed by a simple abstract noun (or a noun preceded by an adjective).

... it (his dream) was so hard lokked in pe whicch of forgetynge $25 / 3$

De affeccions of meche folk aren... faste fetered in pe panter of auarice 31/26 With here stikkes sche fedith pe flawme of leccherie $37 / 5$

$\ldots 3^{\text {if }}$ pou drank of pe chalis of reuerence... it wolde make pe toty $23 / 3$

Be pou panne besi in pi gostli chaumbre of wisdom ... to make a tresory 21/10 ... feterid with pe bond of bondage $21 / 9$

... pou schalt no lengere kepen pe cloistre of bondache $25 / 32$

Sche hath plesid pe longe with affluens of godes $29 / 13$

\section{F. POINTS OF SYNTAX}

N.B. From a syntactical point of view this text offers some interesting features. $A$ few of them do not seem to have been recorded before and some others are rare. See sections $2,7,17,20,21,23,28,54,67 \mathrm{iii}$ and 70 a. No attempt has been made to give a complete and detailed description, which would be out of proportion with regard to the short length of the text. In particular I have often left out those features which are familiar in both present-day English and Middle English.

The treatment is based on the arrangement in F. Th. Visser's An Historical Syntax of the English Language, Parts I and II. References to this work are abbreviated Visser H.S. For the syntactical units with two and more verbs I have adopted the arrangement of F. Th. Visser's $A$ Syntax of the Language of St. Thomas More, references to which are abbreviated Visser, More. References to T. F. Mustanoja, A Middle English Syntax, Part I are abbreviated Must. 
I. Syntactical units with one verb

Verb and Subject

Subject not expressed

1. In the following instance the subject pronoun is omitted and has to be supplemented from the context:

Not alwey pe fader strokes his sones heued. but wanne he findep him fawty $\mathbb{\mathbb { O }}$. rebukip him with a scourgyng $9 / 8^{1}$

Both subject and predicate are absent in:

as often $\mathbb{U}$, sik as often $\mathbb{I I}$, sumned $7 / 28$

I was juel born for $\mathbb{I I}$ ouzte of matrimonye $17 / 1$

haue pou litil katel: $\mathbb{C l}$ litil kare 29/5

cf. $\S 15$.

2. The type me likep

There are a good many instances of the so-called impersonal construction, with a personal pronoun in the oblique case preceding the verb in the third person singular. The following instances reflect the $\mathrm{OE}$ construction:

me heuye $P$ with my sekenes $9 / 5$

This use is not recorded by either OED or Visser H.S.

panne nedith pe not to borwe $7 / 25$

pe nedith to be a schamed $15 / 13$

in dispeir $\mathrm{per} p e$ not be $25 / 14$

as $p e$ good likep $\quad 23 / 33$

him liste not euen soupe $39 / 23$

heve lust sum del to with drawe here hand $29 / 14$

poow hym seme heuy chered $27 / 7$

him pinkith he hath a feste be pe wombe ful $39 / 22$

me wantip manye pinges $33 / 1$

In the following instances nouns take the place of pronouns preceding the verb. In these cases, where there is no distinction zero case-ob-

1 The sign $\mathbf{C}$ denotes the omission referred to. 
jective case, there is often nothing to distinguish them from personal constructions with a subject.

3 if $a$ man wante richesses $\quad 31 / 27$

pe emperour of blisse... likidde to leuen pore $33 / 11$

(to like was used in personal constructions also in $\mathrm{OE}$ )

a wantoun wille to be refreined nedith a bridel of arest $9 / 7$

The interpretation of the above constructions is complicated by the fact that they are complemented by a noun in the common case. In $\mathrm{OE}$ this complement would often be in the genitive and can be regarded as an object. Here the complements can be taken as objects or as subjects, - it is impossible to decide which. The same applies to the following instance, where a pronoun in initial position shows no distinction between zero and objective case:

pat pinkep him most holsom 39/26

The structural ambiguity of constructions like the one above must have been one factor in the gradual decline of the impersonal constructions. Besides, as shown below, many of the verbs which are used in the impersonal construction also occur in personal constructions with unambiguous subjects. Some of them had had this rival construction since the $\mathrm{OE}$ period.

pou wantede riche clopes $15 / 22$

pou wantes pi delizt $3 / 3$

how may manye pinges wante $33 / 3$

as pei may wel lest $27 / 22$

zif pou list to be faire $5 / 2$

pou schalt not nede $\quad 39 / 3$

A contamination, illustrating the wavering between the personal and the impersonal construction, is:

pe nedist not to conseille with pi stomak $37 / 27$

cf. the two types pe nedith and pou nedist. 


\section{Subject expressed}

\section{It as subject}

It is used without reference to any agent in:

as it seid be fore $19 / 23$

4. Non-locative there as structural subject

per kummep no vitalles on my bord but simple $\&$ pore $39 / 13$

pere is non bed soft to a seke man $27 / 29$

This there is, however, not used in the following instances, where in $\mathrm{MnE}$ it would be preferred:

for after pis lizf $\mathbb{O}$ is non sekur seruice $23 / 14$

in holi wryt ar is non obstacle $19 / 18$

\section{Men as subject}

In this text men is mostly construed as a plural.

wen men loken lest after socour $31 / 22$

men loue not to wrastele clothed $27 / 24$

when men ben pechir prouzd $37 / 7$

a man + singular verb seems to be used in the same function:

3 if $a$ man wante richesses $\quad 31 / 27$

6. Apo koinou construction

The following construction consists of two syntactical units with one element in common, which functions as the subject in the second unit: per is non erthely lord may priue pe of pis fraunchis $23 / 33$

7. Relative pronoun as subject

The following construction with which as subject is not common in ME. According to Visser H.S. $\S 534$, note, the construction is more typical of the 16th-18th centuries in which it flourishes mostly in imitation of Latin. Visser's first quotation is dated 1481. But see Must. p. 203 with examples from Chaucer and Caxton.

penne god schewede a tre to Moyses. wich wan it towchede pe flod. a non it was turned in to swete licor $41 / 13$

Note that $i t$, the subject of was turned does not refer to tre, but to flod. 


\section{Subject repeated}

The pleonastic insertion of a pronoun after a noun is quite normal, especially when the noun-subject is separated from its verb by a lengthy adjunct. It is to be noted that this use is very frequent when the member repeated by the pleonastic pronoun is in initial position.

vnresonable bestes poow pei eten meche: 3 it pei kepe pe mesure pat nature hath tawt hem 39/7

pis tre be tokenep pe cros of our sauiour. wich \& it were wel inpressid in a mannes herte: not al only hard fare... but also oper tribulaciones it schulde turne to swetnesse $41 / 14$

faire fetoured body $\&$ clennesse of souzle selden nestele pei to gedere $3 / 9$

who so seruep god best in pis valei of teres: lord in pi holi mounteyn he schal sitten heizest $23 / 15$

When the subject is a syntactical unit it is occasionally repeated by $i t$ : wereof bei profiten vnnepe it is perceyued $13 / 22$

9. The anacoluthic subject

Sometimes a 'subject' in initial position is left in the air with no verb to serve as its predicate, a new subject being improvised instead. Such anacolutha need not be a sign of untutored style. They often serve rhetorical effects which Modern English cannot imitate.

summe whanne pei reden of pe abstinence of Jerom $\&$ German... it tikelith pe eres $37 / 20$

pese wymmen pat peynten hem self with crafti wateres how fouzle pei ben to loken vp on experiens schewet $3 / 31$

emperours \& kynges sitte pei neuere so hize. heve trone tremblip vndur hem $\quad 13 / 23$

10. Concord between subject and predicate

a. Plural verb through attraction.

In spite of a singular subject the verb may be in the plural owing to the proximity of a plural form:

pe nobleye of many gentilmennes children suffren sich a clips $13 / 22$

a zens pese mutacions grucche no man for pei ben naturel $31 / 12$

that grucche is modally marked is improbable, see context.

b. Singular verb accompanied by plural subject. 
This is often the case with introductory there in front position, but it is not true, as Visser H.S. $\S 84$ shows, that the subject character of there is the sole reason for this phenomenon.

per kummep no vitalles on my bord but simple \& pore $39 / 13$ manye hap per ben $33 / 8$

that these endings of the verb may represent southern plurals is unlikely as in unambiguous instances $-e(n)$ is always found. Compare the following instances where the plural verb is used:

two pinges per ben $23 / 4$

many men per be $39 / 16$

c. Richesse, richees-used by the side of richesses-are construed as plurals

richesse taken neuere here leue be per one $33 / 16$

d. Plural compound subject with singular verb

Sometimes two subjects, connected by and or ne are accompanied by a singular verb contrary to modern usage.

pus enformeth vs holy wryt \& Austeyn pe doctour 5/9

pe vertu ne $p e$ swete smel of pe rose is neuere pe lesse. pat his moder is a porn $19 / 25$

redines of conseil \& prudence of gouernaunce hath rered vp many feble $7 / 1$

e. A copula connects nouns of different number

In such cases the verb often takes the number of the first noun or of the second noun.

now may pou be certein... who hap ben pi feined frendes $35 / 4$

Who, which can be taken as singular or plural, is here obviously taken as singular.

\section{f. Nouns and referring pronouns}

Occasionally the referring pronoun is different in number from the noun to which it refers. Thus often with collective nouns.

many a likerous man hap pouerte with chastesinge tawt to kepe temperaunce pat philosophie with fayr speche myghte neuere brynge hem to $27 / 19$

it is pe olde manere of vnkynde folk sone to forzete what is don for hem $31 / 2$ 


\section{LANG UAGE}

pe affeccions of meche folk aren so faste fetered in pe panter of auarice pat 3 if a man wante richesses: $p e i$ seize he hath no good $31 / 26$

pou derst not haue suspescion to pin neyzebour. pat $p e i$ wole breke pi walles $27 / 14$

\section{Verb without Complement}

11. The following verbs have no complement, in which sense they are obsolete in MnE:

alle pi lemes schal feblen $3 / 14$

forzete pou not pis olde prouerbe... \& rule per affter 25/22

prey pacience helpe pe to bere $7 / 32$

12. may used independently

Independent may has the meaning of 'to have power, influence':

3 if he may more pan pow $35 / 10$

13. wil used independently in the idiomatic phrase:

wil pi lord $n y l$ pi lord $25 / 15$

14. The use of vicarious to do without an object

In the following than-clauses, dependent on a comparative, to do is used vicariously for the preceding verb:

3e glotenye sleeth mo pan pe sweerd doth 39/10

pi grucching weihip more pan doth pi seruyse $23 / 28$

In the latter example the subject follows to do, which is rare according to Visser H.S. § 191.

\section{Verb with Complement}

\section{A. Distinct subordination ('copulas')}

15. The semantic emptiness of the copula to be often causes it to be omitted, as in the following instances:

wel worth pe wand pat makip wilde childer tame $9 / 10$

as often sik as often sumned to zelden a rekening $7 / 28$

alwey fy on pride $15 / 25$

in erthe a knaue in heuene a kyng $23 / 17$ 


\section{A N G UAGE}

a gentil professioun pat made pe seruant more penne his lord $25 / 1$

a noble dyuors: pat departip a man fro wast expunses $35 / 3$

S. wel $37 / 4$

N.B. It should be clear that although some of the above cases present ellipsis of the copula, the above statements are complete as they stand. All these instances are exclamatory in character and the absence of the predicate is due to a striving after conciseness, cf. $\S 1$.

The complements of a copula which are discussed below include nouns, the word so and prepositional phrases.

\section{Complement a noun}

Absence of the indefinite article is regular in such collocations as freend to, etc., in which the noun is qualified by a prepositional adjunct.

hardnes is freend to vertu $37 / 15$

lufly schap of body: is lemman to lechery $3 / 26$

pou art son to ... an emperour \& coseyn vn to seyntes $15 / 6$

were pou frende to pi souzle $7 / 33$

In the following instance rebel should probably be taken as an adjective, cf. OED, rebel, adj. A.

pe flesch is rebel a zens his lord pe spirit $7 / 20$

As for the type: he is (a) lawyer (Visser, H.S. § 256) our text has mostly instances of the now normal construction with the indefinite article:

he was a gret prinse $25 / 29$

he was a philosophore $23 / 36$

his fader was a seynte $19 / 4$

pou art here a straunger $27 / 24$

in erthe a knaue in heuene a kyng $23 / 17$

17. Complement the word so

Aduersite: I ham komen of a pore nest. Resoun: $S o$ is pe most part of men $15 / 13$

This usage was not yet common in the Middle Ages. Cf. Visser H.S. $\S 287$ : 'This usage became common about 1600 '. 
18. Complement a prepositional phrase

pat s of pyn owne studie $\quad 3 / 17$

pat is of euene age $7 / 10$

Note the place of the prepositional phrase in:

pat to kyng was captif $25 / 6$

B. No distinct subordination (verb + object)

19. Indirect object as sole object

In the following construction the indirect object $p i$ is the complement of the copula $b e+$ adjective:

penne is $p z$ better pat is pi souzle free $21 / 4$

in which case $p \imath$ is to be explained as an occasional form of $p e$, the object pronoun corresponding with pou. Cf. Visser H.S. $\S 334$ under bet(ter).

In

pei. . feynen hem hornes $5 / 1$

the object hem is probably due to analogical formation of other French verbs such as se souvenir, s'étonner, cf. Visser H.S. § 328.

20. Indirect object used as heralding object ${ }^{\mathbf{1}}$

Paule zaf $\mathrm{htm}$ not preizere to hele sik Tymope 9/30

in which him refers to Tymope. This use of him is not recorded by the OED or by Visser.

21. Of-complement as sole object ${ }^{2}$

In the following construction:

wanne pe asaye to souzpe of pe same broth' panne is it so bitter pel may not per of $37 / 23$

it is just possible that may is used elliptically for may not souzpe. This would mean 'cannot eat' and does not very well fit the context; also the to before souzpe makes it improbable. It would, therefore, be

1 for the term 'heralding object' (or 'provisional object') see Visser HS $\$ 501 \mathrm{ff}$.

2 Visser's 'causative object', $H S \S 370 \mathrm{ff}$ 
tempting to take may as a notional verb in the sense of 'to like'. This construction with an of-complement is well exemplified for to like, smell, feel, etc. (Visser, H.S. § 375) but not for may. Nor is this meaning of may recorded in the OED. It should be noted that the idiom occurs in German and cf. the Dutch: 'Ik mag dat vette eten niet', literally translated: 'I may not that fat food'.

I am grateful to Professor Visser for pointing out to me that he has found a similar construction in the romance Emaré (ed. Rickert, E.E.T.S. E.S. 99) composed about 1400. Line 401 runs: Of pe mete non he myzth. Here the context clearly does not provide any verb which could possibly be connected with myzth.

22. Prepositional object as sole object

Note the following verbs and their prepositions:

sad man \& whizs wol joize of pi presens $35 / 12$

to regne vp on Israel $15 / 18$

noping pat longep to man is glorious but vertu $3 / 20$

pei... forfeten azen pe lore of Petir \& Paule $5 / 2$

he preizede for remocion of siknes $9 / 24$

but also:

I prey... after hele $9 / 22$

on summe sche vouchep saf ... a fewe ragges $13 / 30$

nature lokep after no delicacies $39 / 22$

zif pou climbe on pis wheel loke affter non opur $31 / 16$

pyn vnlusti schap pou pleynes on $5 / 3$

but also:

pou pleynede pe not of pis $7 / 33$

When the complement of a prepositional group-verb is where or there, the preposition follows these words immediately and sometimes forms one word with them.

per of art pou not to wyte $19 / 23$

vereof pei protiten vnnepe it is perceyued $13 / 22$

23. Place of the preposition

The normal order is for the preposition to precede the (pro) noun. 
his hony of his wex recorden of his vertu $5 / 19$

pei reden of pe abstinence of Jerom 37/21

End-position of the preposition is found in attributive clauses introduced by the particles pat, as and but, which cannot be preceded by a preposition (Visser, H.S. $\S 410$ ).

many men... wolde receyue... seche vitailles as pou letist litil by $39 / 18$

many a likerous man hap pouerte... tawt to kepe temperaunce pat philosophie... myghte neuere brynge hem to $27 / 20$

In the construction:

pin vnlusti schap pou pleynes on so meche: is lent pe but for a tyme $5 / 3$

there is immediate contact between antecedent and attributive clause (apo koinou construction) and the only possible place for the preposition is at the end. This type is rare before the beginning of the MnE period. Cf. Visser H.S. §412a.

24. Direct object as sole object

The reflexive object can be expressed by the compound personal pronoun:

pou schuldist honoure pi self $3 / 12$

many... hauen be trappid hem self in endeles praldam 21/17

so may pou dignify pi self 21/11

or by a personal pronoun:

how mayt pou pleyne pe 23/29

sum men pride hem alle one of nobeley of pere cuntre $11 / 23$

hold we $v$ s content $39 / 30$

24. a. When the object is a clause, it is often non-introduced:

haue mynde $\mathbb{C}$ pou art here a straunger $27 / 24$

he was beden be pe lord $\mathbb{G}$, he schulde not take 5/26

glad be pi spirizt. af his presoun is ruynouzs $11 / 1$

$\&$ made II he was a gret prinse $25 / 29$

douzteles triste II pi lizf schalt pou haue $9 / 33$

These semi-paratactic constructions could no doubt be used for effect in oral delivery. 
25. The heralding (provisional) object

Sometimes a syntactical unit functioning as the object of a transitive verb is first announced by $p i s$

now pou knowest pis wel pat... 27/32

wete pou pis wele pat... 21/16

pou wost pis wel pat... 23/2

These heralding objects are commonest in Old English and become scarce in Modern English. Their use seems redundant at first sight, but the device could impart emphasis to the following clause and clarify the structure of the sentence.

26. To haue is used as a notional verb with an object in:

whi haue I infirmite? $9 / 12$

neper Paule hadde his askyng $9 / 23$

eche ping hath his mesure $7 / 11$

perauenture pou hast abelte to honeste studie $5 / 37$

27. To haue + noun is often used in approximately the same sense as the verb etymologically related to the noun:

sich a beli seruaunt ha $p$ no consideracion how... 39/26

pou derst not... haue suspescion to pin neyzebour $27 / 14$

pi souzl may... haue contemplacion of heuene delices 23/30

haue mynde pou art here a straunger $27 / 24$

summe... hadde delit to be fed... with bred $\mathcal{E}$ water $37 / 18$

in pinge pat moste nede failep a gentil souzle hap no delit $7 / 7$

alle only dame pride $\&$ here nyse dowteres haue scorn of pore men $35 / 13$

pei enemye may werst holde haue of pe $27 / 25$

'The analytic type seems to be used to represent the action or proceeding as something experienced, got at, attained or enjoyed by the person denoted by the subject', Visser H.S. $§ 148$.

28. Hedur and bedur as verbs?

Though I have chosen to emend the sentence

While wele $\&$ woo pleyen at pe balle. nepur of hem kan bolde longe pe balle stille. but hedur $\mathcal{E}$ pedur it contynuely $31 / 21$ 


\section{LA N G UAGE}

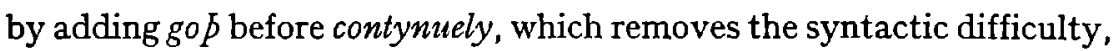
I draw attention to the possibility that hedur and pedur in their use as verbs with an object represent a nonce-use of the author; but it is difficult to find similar cases of conversion. Cf. also note to this sentence.

29. Will + object expressing will or desire

he schal wille... pat he hadde lyued porer $35 / 22$

what menep pe but vanite pat pou wolt pat men talede of pe $13 / 4$

30. To do + object is used in:

it bringith a man to do surfet $39 / 28$

to do... feithful seruise $25 / 19$

whi is a wilde colt teyzed pat neuer harm dede? $9 / 13$

From the above examples it appears that this use of to do + object is often equivalent to the verb etymologically related to the noun. Cf. $\S 27$.

31. Vicarious to do + indirect object

perchance it may be tide to pe pat hap don to manye. pat porw pi true seruise: pou schalt be weddit to liberte $25 / 20$

in this instance the first pat should be taken in the sense of 'that which' and hap don repeats be tide.

32. The object used twice

Sometimes the object, placed at the head of the sentence, is repeated in the form of the pronoun it after the verb. In the following instances the object is a syntactical unit:

pat pou wantes pi delizt he dede it for pi profizt 3/4

pat pe sones of pore men gouernen may riche remes. telle it for no typingges 13/20

Similarly with other pronouns:

Josue Judas Machabe Ector \& Arthour. deth hath taken hem presoneres $7 / 5$

33. Direct object + predicative adjunct

Occasionally the predicative adjunct is preceded by for:

telle it for no typingges $13 / 20$

cleyme heuene for heritage $15 / 8$ 


\section{LANGUAGE}

A dependent clause is also possible: trupe... made he was a gret prinse 25/29

cf. MnE 'made him a great prince'.

34. Place of the object in verb-adverb combinations

The place of the object is variable (cf. Visser H.S. $\S 668$ )

pou mayt haue no betere besom to swepe a wey pe motes of infames birpe 19/27 pei wole... bere a wey pyn huches $27 / 15$

pou mayst no betere plesen hym. pan driue hym a wey $\quad 39 / 19$

but vertu holde hem vp $13 / 24$

\section{The Present Tense Form}

35. The gnomic, or neutral, present takes up a good deal of the available presents.

place make $p$ no man holy! but man makep holy place $11 / 22$

The present is used occasionally where $\mathrm{MnE}$ prefers to be + form in -ing.

wilis pe flesch of pe spirit wrastlen to gedere $9 / 1$

Indeed, no instance of the 'progressive' occurs in this text.

The present is used with reference to future time in cases where futurity is implied by the context:

after pis lizf is non sekur seruice $23 / 14$

Similarly after injunctions in the imperative:

peynte pi souzle with vertues \& panne art pou pank worthi $3 / 16$

be pou pi self noble $\&$ pou art neuer pe lesse worthi $11 / 5$

The present alternates with schal + infinitive in:

pou wakest at morn meche pe merier... pou schalt not nede to wynde pi tepet for pe hed ache $37 / 27$

The present is also used to refer to an action that will be completed in the future:

whanne pou komest to pe heizest poynt $31 / 16$

wanne dep komep $35 / 24$ 


\section{The Preterite}

36. The preterite is often used where Present-day English uses the to have + past participle construction. The preterite is often accompanied by the adverb neuer (cf. Visser H.S. § 807)

a feipfullere felow found pou neuere $7 / 27$

I sinnede neuer gretly $9 / 12$

whi is a wilde colt teyzed pat neuer harm dede? $9 / 13$

homly folk \& rude brouzt me in to pis worlde $13 / 14$

But to haue (occasionally to be) + past participle is also used:

he... hath zeuen pis decre $19 / 16$

I ham komen of a pore nest $15 / 12$

fortune hath spoiled me of my goodes $31 / 24$

Just as there is a gnomic present there is a gnomic preterite:

semelynesse made neuere 3 it man or womman chast 3/24

The preterite is used modally

1. in the apodosis of hypothetical statements:

were pou frende to pi souzle. pou pleynede pe not of pis $7 / 33$

Similarly when such a statement is understood:

pou haddest wele in pis lizf $23 / 14$

Present-day English would prefer constructions with auxiliaries.

2. in conditional clauses:

3 if it happede $23 / 8$

E. euere haddest pou feithful fere... now schalt pou be dere to hym $35 / 10$

In later English constructions with should are used by the side of these modal preterites.

\section{The Modally Marked Form}

37. The modally marked form can be used

a. in independent units

i. to express a wish or a command: 
glad be pi spirizt $11 / 1$

wete pou pis wele $21 / 16$

sik not $15 / 5$

Crist forbede $23 / 8$

ii. with a 'tacit mental limitation on the part of the speaker' (Visser, H.S. $§ 859)$ in:

mi desir were to be heyzere $5 / 31$

seli were pe creature pat wolde folwen pi steppes $33 / 31$

iii. in the following type, which has a concessive character:

go were pou wolt. 3 if pouerte kepe pin hows pou derst not be a gast $27 / 12$

flater fortune neuere so faste a man... sche may not lette pouerte to drawe bope endes of pis dedly lif $35 / 18$

b. in dependent units

i. in subject clauses (or at any rate syntactical units that may be explained as such, cf. Visser H.S. § 863) after impersonal constructions.

3if it happe pat pou falle $31 / 18$

zif hit happe pat pou sitte $13 / 7$

it may not be. pat contricioun prife a mong delices 41/1

According to Visser H.S. $\S 864$ the difference from the frequent rival construction with a modally zero form is in the modality of conditionality imparted by 3 if. Here follows a modally zero form:

him pinkith he hath a feste be pe wombe ful $39 / 22$

ii. in object clauses dependent on verbs of wishing, allowing, thinking, entreating, etc.

statutes also suffre not pat pou be a lawful heire of erpeli possessioun 19/19

to suppose. pat per be any hender path $33 / 12$

iii. in final clauses

I ham a ferd lest pou suffre pe same febre $37 / 19$

lest pou be fouzlere $3 / 30$

iv. in temporal clauses

he wol not a bide. to pou seende for symnelle $39 / 20$ 
$\mathrm{v}$. in conditional clauses

3if hit happe $13 / 7$

be a fool drunken $37 / 8$

vi. in concessive clauses

what mannes childe pat euere hit be $15 / 2$

poow pi dore stond wide open $35 / 5$

be it neuer so greuous $35 / 23$

vii. in clauses of exception [conjunctions pen, but (zif), but (pat)]

litil worth is pe blosme: but ony frute folwe $3 / 28$

it is non conseille to the. but 3 if pou haue forzeten $7 / 19$

\section{The Infinitive}

38. Infinitive as subject

The following example is a construction containing a noun + infinitive with to as subject

a wantoun wille to be refreined nedith a bridel of arest $9 / 7$

The infinitive can be regarded as an adjunct to the noun. See Visser H.S. $\S 905$.

The infinitive with to may also be dependent on a group consisting of $i t+i s+$ adjective + noun

it is inpossible fire to bren in water $39 / 37$

As Visser shows, H.S. $\$ 911$, the noun was originally used as an indirect object. The construction was already losing ground in the ME period and came to be replaced by the construction with for or to preceding the noun (it is impossible for me to come).

39. The infinitive as object

In the following construction

enforce pe in pis perti to be vnlik to hem of pi conuersacioun $\&$ nouzt how pou ware goten $19 / 12$

enforce is complemented by to + infinitive as second object, but the expected second infinitive in the next unit fails to come and the construction falters. 
40. The infinitive as adjunct to an adjective

how fouzle pei ben to loken $v p$ on $3 / 32$

41. The infinitive as adjunct to a noun

In the following instance the infinitive is accompanied by a preposition in postposition:

pou wantede riche clopes to leize pi child jnne $15 / 22$

42. The infinitive as adverbial adjunct

In the following instance the construction with infinitive alternates with an adverbial clause of purpose:

manye studien seche stories: not for pei wolden lifen betere. but for to kunne talke of perfeccioun 37/24

The use of for to preceding the infinitive is not restricted to adjuncts of purpose, cf.:

he enformede him for to vsin medicyne 9/31

43. The infinitive after $p a n$

In the following instances an infinitive with or without to is used after pan, where MnE would have by + form in -ing:

pou mayst no betere plesen hym. Pan driue him a wey 39/19

pere is no schortere weyze to soften his dures: pen with a buxum herte to do hym feithful seruise $25 / 19$

44. The object to the infinitive

The object dependent on an infinitive often precedes it:

pe sagis... kowde no keies fynde pis visioun to schewe 25/5

\section{The Form in -ing (or-ande)}

45. The two forms in -ande occurring in this text function as

i. subject

pe weiferande at his 3 ate hadde free entre $33 / 25$

ii. prepositional adjunct:

famouse storye of pe induellande 11/22 


\section{LA N G UAGE}

They are really substantives and do not form part of the verbal system.

46. The form in -ing can be used

i. as a predicative adjunct to the subject:

kyng Nabugodonosor. slepynge saw a... visioun 25/2

he kowde not telle wakyng what he hadde seen $25 / 4$

ii. after a copula:

hinderyng of pe ton is forthing of pe topere $9 / 2$

In this position the form in -ing alternates with the infinitive preceded by to, cf.:

for pe to serue: is to regne $23 / 16$

No rigid rules as to the distinction between the two constructions can be given (Visser H.S. $\S \S 901$ and 1051).

Cf. also:

Here proper werkyng is to turne her wheel a bowte $31 / 15$

ii. as a related free adjunct. In the following instance it expresses reason:

pe lawe reuerently faueringe pe sacrement of wedlok ponysch... children vaborn in mulori $19 / 14$

Note the following forms in -ing-some of them in the plural-in purely nominal functions:

wrastelinges $5 / 37$, offryng $41 / 7$, pleynynges $31 / 4$, biddyngges $23 / 35$, kouerynge 29/12, leuynge $35 / 18$.

47. The object of the form in -ing

The -ing form may be followed by an of-adjunct, which is syntactically equivalent to a direct object:

hinderyng of pe ton is forthing of pe topere $9 / 1$ gret of kunnynge of goodnesse $5 / 17$

\section{The Past Participle}

48. The past participle, when used as an attributive adjunct, may be preceded by a 'flat adverb'.

a wrong formed pleynt $27 / 27$ 


\section{ANGUAGE}

II. Syntactical units with two verbs

\section{Direct Nexus of Two Verbs}

49. Syntactical units with two verbs can be of three types. The first verb is not subordinated to the second, the first verb is slightly subordinated to the second or the first verb is distinctly subordinated to the second.

Of the first type note the following construction with an infinitive not preceded by to:

I suppose neuere in pis lizf be opur but a seruaunt $23 / 12$

The most important type is that with distinct subordination of the first verb to the second and will be dealt with in the following sections.

\section{A. Auxiliary + Infinitive}

50. to be + infinitive

Occasionally the infinitive after to be has a passive implication:

per of art pou not to wyte $19 / 23$

but the construction with to be + past participle is also used (a fifteenth-century development according to Visser, More II § 413):

propere dedes ben to be charched $19 / 7$

to $b e+$ infinitive can express futurity with an admixture of predestination:

pe more mede is to komen $33 / 8$

The rival construction with shall and will is more frequent.

51. to haue + infinitive

to haue + infinitive is used to express duty or obligation in:

pou... hast fer to go $27 / 24$

However, the adjunct denoting distance, fer, shows great resemblance to a direct object and the construction thus approximates the type $I$ have nothing to eat. See Visser, More $§ 419$.

52. to do + infinitive

Periphrastic to do + infinitive occurs in: 
what noizede it Abraham pat his fader Thare dede honour aliene goddes? 19/5 According to Mustanoja p. 602 this use is probably rather similar to that of gin in the periphrastic preterite. The earliest prose instances date from about 1400 ( $M$ ust. p. 603). to do in negative declarative units with not is not found in this text, nor is it found in interrogative sentences.

\section{3. schal + infinitive}

i. in the following sentence schul, expressing what is right or becoming, is almost equivalent to should, ought to.

pi most pore natiuite schul descounfed oure prouzde hertes $15 / 23$

ii. schal + infinitive is also used to express the will of the speaker:

pe sone schal not beve pe wickidnes of pe fader $19 / 16$

iii. Another function of schal + infinitive is its use in statements accompanying conditional clauses (or equivalent generalising relative clauses or imperative units) in which the statement with schal denotes that the action will take place on the condition expressed in the subordinate conditional clause.

lefe wel $\delta$ dize wel. $\&$ panne schal pi birpe. be to pe no preiudice $19 / 1$

who so seruep god best... he schal sitten heizest $23 / 16$

Compare $\S 35$ where in a similar case the present is used and $\S 58$ iii where may + infinitive is used.

54. $w o l+$ infinitive

A rare occurrence of will + infinitive at this early date is its use to express a mild command or advice.

for pi wille seuer. pat not he pat lest hap: but he pat most coueitep! is most pore $33 / 5$

(Modern English 'please note').

This use of will + infinitive to express a mild command is first recorded in OED for 1824 and Visser finds the first example in Shakespeare (More, §438).

wol + infinitive, in accordance with its original meaning, is occasionally used to denote a future action dependent on the will of the speaker 


\section{A NGUAGE}

he wol not a brde to pou seende for symnelle $39 / 20$

with jnne a fewe daies wole deth sende his messanger $5 / 4$

55. schulde + infinitive is used

i. in statements of duty, obligation or propriety:

mete for drynk schulde be taken be maner of medycin $39 / 5$

man .. schulde be here lord $39 / 8$

in this sense it alternates with awte

hym awte to do $39 / 12$

ii. in questions, also rhetorical questions:

wh1 fortune schulde with drawe here fauour fro me? $31 / 5$

how scholde pouerte priste pe doun? 27/21

what schulde I more seye? $37 / 10$

iii. after phrases expressing expectation, thinking, knowing, etc.

nouzt I mene pat pe souzle schulde of quantite be gret $\quad 5 / 16$

iv. after verbs expressing desire, wish, etc.

he was beden .. he schulde not take to pe semblaunt . of Helyab 5/26

$v$. in headclauses to express the result of a hypothetical condition contained in the subclause

were pin appetit helid of couetise pou schuldist pinke pouerte a restful kouzche $27 / 30$

3if seknesse $\delta$ age hadden fow ten a while with pe' pe victone schulde be heren $7 / 4$

56. wolde + infinitive is used

i. to express volition in the past:

pel wolde hfen betere $37 / 24$

kynde wolde not 3iffe pe pat ping $3 / 6$

selı were pe creature pat wolde folwen pı steppes 33/31

ii. in a sense equivalent to 'would like to' in contexts where the timesphere is not really the past:

wenne synne wolde asaile be $3 / 4$

wel I haue aspied pat pou $\mathcal{E}$ lust wolde krsse $39 / 15$ 
Similarly with fayn:

I wolde fayn be faire $3 / 29$

Would + infinitive in this function is now obsolete.

iii. in hypothetical clauses

woldest pou suffre pi mynde to wete pi mete in Cristes wondes pou myght fynde no betere sause to make pi mete sauery $41 / 9$

iv. in independent units after a combination of a conditional and a hypothetical idea

3if pou drank of pe chalis of reuerence... it wolde make pe toty $23 / 4$

57. can + infinitive

In the following sentence the infinitive kunne is used where English now requires to be able + infinitive

manye studien seche stories... for to kunne talke of perfeccioun $37 / 24$

A construction with to be able occurs in:

pou art pe more able to sorwe for pi synne $39 / 36$

58. may + infinitive

i. may is often used where it has retained its original meaning and is interchangeable with can

non erthely lord may priue pe of pis fraunchis $23 / 33$

but cf. iii below.

ii. may not + infinitive is used in contrast with modern usage to denote absence of possibility:

pere mayst pou not longe sitte $\quad 31 / 17$

so it may not be. pat contricioun prife a mong delices $39 / 37$

ping pat may not dize: may not be sik $7 / 26$

The original meaning of 'to be strong, to have power' is still evident and the difference from can is not easy to ascertain.

iii. In some cases it is possible that may has a connotation of uncertainty: 


\section{A N G UA G E}

vse honeste in lyuyng $\&$ pou mayt haue no betere besom to swepe a wey pe motes of infames birpe $19 / 26$

nede may sone be riche jnow. but couetise seyzeth neuer hoo $33 / 4$

It is evident in:

perchance it may be tide to pe $25 / 19$

iv. may can be used as an auxiliary of modality in clauses dependent on negative or prohibitive statements. In the following instance it is dependent on a concessive clause:

poow pe comen lawe inhibete pe... in holi wryt is non obstacle pen pouz may be an holy lyuere $19 / 18$

v. in clauses expressing a comparison:

also litil as pei may wel lest : pilgrimes trussen with hem $27 / 22$

vi. after superlatives:

pe greuest bondage pat may be is to be sugget to synne $21 / 3$

59. might + infinitive is used

i. in the sense 'was able to' in which meaning it can alternate with could:

pe wateres of Marath were so bitter pat pe folk of Israel mygth not dryngen of hem $41 / 12$

cf. the construction with kowde:

it was so hard lokked... pat he kowde not telle... what he hadde seen $25 / 3$ pe sagis... kowde no keies $f y n d e$ pis visioun to schewe $25 / 4$

ii. in clauses dependent on a hypothetical statement, to express possibility:

woldest pou suffre... pou myght fynde no betere sause to make pi mete sauery $41 / 10$

60. dare + infinitive

pou derst not be a gast $27 / 13$

This is a case where derst (from OE durran) is subject to confusion with thar $(f)$. See OED tharf and dare. Derst is used here in the meaning of need. For the construction in dispeir per pe not be see $\S 2$. 


\section{B. Auxiliary + Past Participle}

61. to be + past participle

In some cases, mainly with mutative verbs, to be is used where modern usage has to have:

I ham komen of koterelles $13 / 27$

pat were come of higze blod $13 / 4$

To be + past participle of an objective verb is used for the passive in cases where in modern usage a rival construction is to have + been + past participle:

affter pe frute is pat is lengest abiden. is a tree demed good or badde $15 / 10$

per to was it ordeined $7 / 18$

were pin appetit helid of couetise pou schuldist pinke pouerte a restful kouzche $27 / 29$

However, as in modern usage, the predominance of the notion of state over that of action often accounts for the to be + past participle construction, there being hardly any verbal meaning left in the past participle. The form of $t o$ be can be interpreted as a copula in these cases. The following represent some more instances:

pou art leid in goddisbondes $9 / 20$

hony was forbede for to be offered $41 / 3$

pou were bove wel porer $35 / 17$

I whas born in a litil porpe $11 / 15$

but also:

her vertu is now more knowen ... be cause pat sche was of pe region of Moab: panne pat sche hadde be born in middis of Ierusalem 11/12

The verb to haue is occasionally used in a passive construction. In the first example it means 'to consider'

I ham had in despit $3 / 19$

may not felicite be had with ouzten worldes welpe? $27 / 32$

A passive construction opening with per is:

per is no ping in erpe don with ouzten cause 23/1

The earliest record of this type in OED is 1533 , but as Visser, More $\S 571$ shows, the construction is attested from OE onwards. 


\section{2. haue + past participle}

It may be noted here that the only rule that can be given as to the respective territories of the to have + past participle construction and the preterite is that the former can always be used, when no distinct separation from the present time-sphere is thought of or implied. The appellations 'resultative perfect' and 'continuative perfect' have been avoided. Compare the use of the tenses in:

whanne nature broughte pe forp... dame Fortune lent pe kouerynge. Sche norschede the \& heder too hath fownden pe of here owne koueres $29 / 13$

sche hath plesid pe longe with affluens of godes $29 / 13$

The have + pp. construction is often used to denote an action that happened once, more than once, frequently or regularly, in a period stretching from a point in the past to the present moment:

it is wreten pat for surfet many on hath perched $39 / 9$

it may be tide... pat $h a p$ don to manye $25 / 20$

many a... man $h a p$ pouerte... tawt to kepe temperaunce $27 / 19$

he hath often vntid hem \& letted hern of her reste $27 / 6$

manye hap per ben. pat hauen... chosen pouerte 33/9

now may pou be certein ... who hap ben pi feined frendes $35 / 4$

No separation from the present time-sphere is implied in the following instances:

fortune hath fro me taken pe riches pat I hadde $29 / 7$

often hast pou herd $25 / 22$

he hap openyd to pe. pe ocasion of vertu $3 / 8$

\section{3. hadde + past participle is used}

i. to express shades of modality, imagination, non-reality, etc.

pou haddist leuere be a glotoun $37 / 4$

ii. modally in the protasis and apodosis of a conditional proposition:

hadde Thamar... ben a fouzl leyth damesele. behap Amoun here bropur. hadde here not oppressed $3 / 24$

for $\&$ pou haddist ben made in erpe! pi falle hadde semed pe lasse $11 / 14$

In the former of these two examples the object is placed between hadde and the past participle, whereas it would now require post- 
position. The modern distinction between the two types was not yet significant.

$$
\text { C. Auxiliary + Form in -ing }
$$

It should be noted that the type he is coming is not used in this text. The present, especially the gnomic present, is predominant.

\section{Indirect Nexus of the two Verbs}

Only the following type occurs:

65. Verb + Pronoun + Infinitive

he enformede him for to vsin medicyne 9/31

Constructions with for to are now obsolete.

The type verb + (pro)noun + form in $-i n g$, which is scarcely used before the end of the ME period, is not found in this text, neither is the type verb + (pro)noun + past participle.

III. Syntactical units with three verbs

\section{Direct Nexus of Three Verbs}

66. A. Third verb an infinitive

The following constructions contain auxiliary + auxiliary + infinitive. The second 'auxiliary' has the function of a notional verb, as is often the case in ME:

pou schalt kun demren $27 / 16$

pou schall not nede to wynde pi tepet for pe hed ache $39 / 3$

67. B. Third verb a past participle

i. auxiliary + be + past participle

he... wolde be comendid $3 / 17$

pouz schalt not be... sent affter $23 / 19$

ii. a form of to be + to be + past participle 
In the following instance this construction expresses what is proper or fit:

propere dedes ben to be charched $19 / 7$

iii. auxiliary + haue + past participle

pat myghte haue had alle maner deyntees $37 / 17$

The use of myght here corresponds with that in the syntactical units with two verbs, cf. $\S 59$ above.

In the following construction:

hadde neuere infirmite haue asailed Job \& Tobye: here holinesse hadde not zit be fully opened $9 / 3$

had haue asailed can be interpreted as 'would have assailed' and since hadde asailed-cf. $\S 63 \mathrm{ii}$-would have served the same purpose, the second of the three verbal forms is a functionless word. There are many examples of this redundant have in the language of the 15th and 16th centuries. Cf. Visser, More $\S 676 \mathrm{a}$ and OED have, v. 26. The first instance cited by OED is for 1440 .

iv. hadde + ben + past participle

This construction is often used in a modal sense, just as hadde + past participle $(\S 63)$

a. in independent units:

here holinesse hadde not zit be... opened $9 / 3$

In modern usage 'would have been' + past participle is preferred in independent units.

b. in dependent units:

after pat he had be rauyched $9 / 15$

pat sche hadde be born in middis of Ierusalem 11/12

pou haddist ben made in erpe $11 / 14$

By the side of this construction the type with was/were + past participle is used, denoting either action completed in the prepast or resulting state, as in:

were pin appetit helid of couetise $27 / 29$ 


\section{A NGUAGE \\ II. Indirect Nexus of Three Verbs}

68. The following are examples of constructions of auxiliary + verb + noun + infinitive:

woldest pou suffre pi mynde to wete pi mete in Cristes wondes pou myght fynde no betere sause to make pi mete sauery $41 / 9$

sche may not lette pouerte to drawe bope endes of pis dedly lif $35 / 19$

The meanings of woldest and may agree with the ones in the syntactical units with two verbs, cf. $\S \S 56$ and 58.

IV. Syntactical units with four verbs

69. Only the following instance occurs:

hony was forbede ... for to be offered $41 / 3$

which is a double passive group amply represented in earlier and later phases of the language, cf. Visser, More $\S 709$ a.

The remaining syntactical features are summarily touched upon in the following sections.

\section{Nouns}

\section{Number}

Material nouns are used in the plural without necessarily referring to different kinds.

pe wateves of Marath 41/11

whanne cornes tymen not: wepith pe frangeleyn $29 / 3$

Abstract nouns occasionally have the plural number without necessarily having a plural meaning. The plural forms strengthen the nominal character of the -ing forms.

pe myghtes of pi souzle 23/31

pe biddyngges of a wicked tyraunt $23 / 35$

pankynges kepen to meche silens. but pleynynges chateren faste $31 / 3$

manere adopts no plural ending in:

per ben pre manere of goodes $31 / 28$ 
but the plural occurs elsewhere:

on diuerse maneres $19 / 15$.

70 a. Conversion

Binyn is used as a noun in:

pi binyn is so feble $23 / 4$

This substantival use is not recorded in OED or MMED.

\section{Genitive}

daies and nyghtes go back to original genitives, but were in the following combination probably taken for plurals:

pe sonne clopith pe eire on daies in his bemes. on nyghtes he hidip hem $31 / 9$

Note the following way of expressing the genitive function:

Thamar Dauid is dowter $3 / 24$

In this construction is is not to be taken as the genitive ending -es, but as the possessive pronoun his. This use was especially common after proper names from OE times onwards. See J. E. Wright, $A n$ Elementary Historical Nere English Grammar, § 303.

The form alderest (not recorded in OED or MMED) in alderest bare $27 / 26$ is used to form an absolute superlative. It represents a remnant of the OE gen. pl. of (e)all with a superlative ending attached. In the Auchinleck MS of Floris and Blauncheflur ${ }^{1}$ the form alderest is followed by a superlative: alderest feblest (1.231).

\section{Pronouns}

72. Personal pronouns

A pronominal adverb is regularly found where modern usage requires it preceded by a preposition:

per of art pou not to wyte $19 / 23$

pe misteries per of $25 / 6$

per to was it ordeined $7 / 18$

The pronoun pat preceded by a preposition occurs also, especially in cases where emphasis is imparted:

1 ed. F. C. de Vries, Groningen, 1966. 
pou art asoiled in pat forme (= from) his obediense $23 / 9$

for in pat drawe pei next to bestis $7 / 14$

who so dispisith pe pore... for pei be pore in pat alle pore he dispisip $35 / 14$

The possessive equivalent occurs in the following sentence, where it may be due to the desire for regularity in the enumeration:

sodeyn slawter of his childryn. seknes of him self. pe los of his goodes were ouer weyk: for to opin his lippes $33 / 28$

The personal pronoun is used in a demonstrative function in:

enforce pe... to be vnlik to hem of pi conuersacioun $19 / 12$

\section{Possessive pronouns}

In the following sentence

richesse taken neuere here leue be per one $33 / 16$

the construction be per one ('by their one') is obsolete in MnE. One is used here as a complement following the poss. pron. per and is almost equivalent to self, selves, cf. OED one 27.d. By the side of the construction with the poss. pron. there existed one with a pers. pron., e.g. bi ham ane in Seinte Marharete, E.E.T.S. O.S. 193, p. 33. I am indebted to Professor Visser for pointing out to me that Cursor Mundi 1.27202 (ed. R. Morris, E.E.T.S.) has the reading 'or queper he be him an it did' in MS Cotton, and ' $\&$ queper be his ane he did hit do' in MS Fairfax. Cf. also the instances in OED, quoted from Cursor Mundi 1. 2021: bi him an (Cott. and Gött.); bi his ane (Fairf.) and be his one (Trin.).

In view of the approximation in sense to self, selves it would seem that the same factors were at work here as with the formation of the compound personal pronouns (cf. me self $>$ myself) and that one came to be regarded as a substantive. It may be noted that Dutch has a corresponding construction op hun eentje.

74. Demonstrative pronouns

pis is used anaphorically implying familiarity with the person referred to:

pe litilnes of $p$ is Dauid $5 / 28$ 
pat is used similarly, but with a connotation of notoriety; cf. Must. p. 171.

pat lusti leuyng $41 / 4$

75. Interrogative pronouns

what, used adverbially in exclamations, is equivalent to $\mathrm{MnE}$ 'how', in which sense it had been common since the OE period.

what wost pou. what is speedful to pe? $9 / 31$

76. Relative pronouns

wich is used four times in this text and is consequently far less frequent than pat as a relative. wich is not used in this text with reference to persons. It is used substantivally in:

pat lusti leuyng wich $41 / 4$

pe cros of our sauiour. wich $41 / 15$

pis tre... wich $41 / 15$

and adjectivally in:

wich name pou mayst not kalenge $13 / 11$

77. The conjunctive uses of pat

i. The most common function of $p a t$ is its use as a relative, referring alike to persons and things. It can also refer to syntactical units as in:

3if hit happede-pat Crist forbede-pat... 23/8

ii. pat is used as a determinative pronoun with non-expression of a following relative:

it may be tide to pe pat hap don to manye. pat... 25/20

but pat is verily pin owne! pat may not be taken fro pe $31 / 34$

fro pe may fortune nouzt bere: but pat sche may bringe to pe $31 / 30$

In such cases modern usage has what or that which.

What occurs in the following construction:

to forzete what is don for hem $31 / 2$

iii. pat is occasionally used after generalising what:

what mannes childe pat euere hit be... sche welkomep hit $15 / 1$ 


\section{LANGUAGE}

pe hungri wiste what sauour pat his mete hadde 33/24

iv. Similarly after adverbs and conjunctions to show subordınation to the main clause:

how precious a juel pat pi souzle is prouep pi redempcion 9/18

after $p a t$ he had be rauyched $9 / 15$

pere inne is no impediment but pat pou mai be a good man $5 / 21$

pat by itself may repeat a conjunction in a second clause:

her vertu is now more knowen be cause pat sche was of pe region of Moab. panne pat sche hadde be born in Ierusalem $11 / 12$

v. pat is also used in the correlative pair pat...pat or what...pat, in which the first member is used determinatively or indefinitely and the second relatively:

kynde wolde not ziffe pe pat ping pat be siknes myzt be corupt $3 / 6$

protitable is pat nede pat constreynep 39/11

what mete sauoreth him best pat pinkep him most holsom 39/25

vi. pat can be used to introduce the 'oratio recta', where it is absent in modern usage

pus seith pe philosophur Plato pat per is no kyng but he kam of seruauntes $15 / 15$

vii. The first part of a comparative of proportion can be followed by pat to show its subordination to the head-clause:

euere pe euyere chere pat pe world schewep pe $35 / 20$

pe more likerous pat pe mete is' pe sunner . 39/27

pe dymmere pat pe fame of p1 cuntre is' pe lithlier $\quad 11 / 8$

vii. pat is often used to introduce clauses, especially final and resultative clauses. But it is also used in cases where its meaning is extremely vague. It may be called a 'stop-gap' conjunction. ${ }^{1}$ In the following cases it is used to introduce what may be interpreted as concessive clauses:

pe swete smel of pe rose is neuere pe lesse pat his moder is a porn $19 / 25$ what noizede it Abraham pat his fader Thare dede honour alıene goddes? 19/5

1 See K C Phillpps, Enghsh Studıes XLVIII, no 5, (Oct 1966), 357 


\section{LANGUAGE}

grucche not pat Crist hath loked vp fro pefes his chosen tresour $9 / 21$

cf. the following instance, where under similar conditions poow is used: sik not poow pou were born nakid $15 / 5$

In the following instance the subordinate clause may be taken as a subject-clause, but it may also be explained as a clause of reason:

penne is pi better pat is pi souzle free $21 / 5$

pat introduces what might be termed an object-clause in :

for pat pou wantes pi delizt he dede it for pi profizt 3/3

but it is impossible to define the exact relation.

\section{Conjunctions}

i. The following are conjunctive correlatives joining negative sentences or part of sentences:

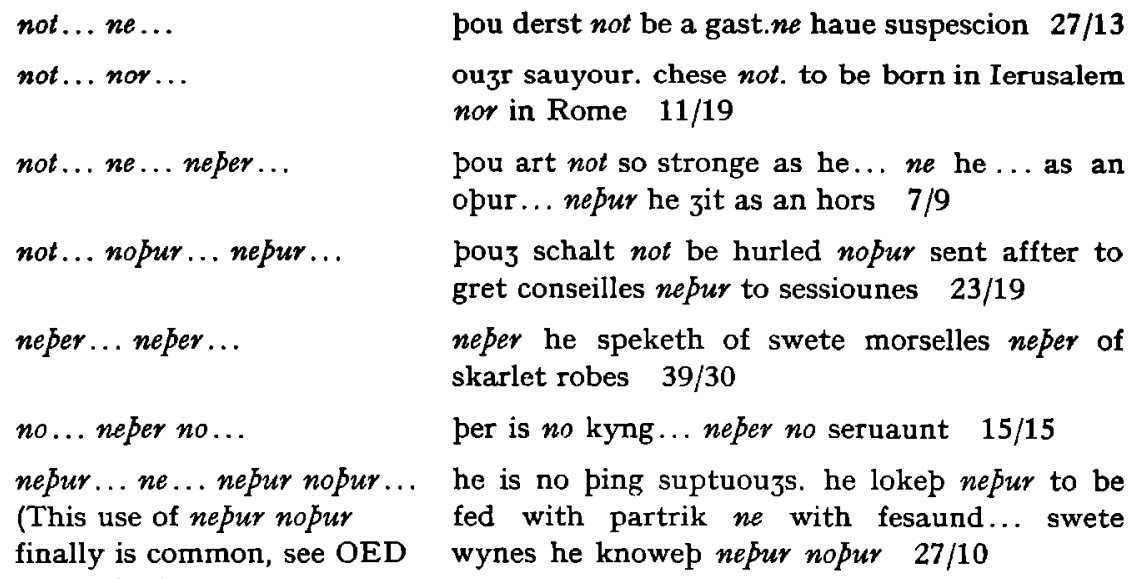
fed with partrik ne with fesaund... swete wynes he knowep nepur nopur 27/10

ii. Conjunctions are often used at the beginning of the sentence (in the MS written with capitals)

And how mayt pou pleyne pe 23/28

$A n d$ wolt pou haue on schort word $25 / 8$

$B u t$ certes in dispeir per pe not be $25 / 14$

$B u t$ it is pe olde manere $31 / 1$

$B u t$ wisdam redeth vs a noper lessoun $31 / 28$ 
79. Word - order

Out of the intricacies of word-order I draw attention to the following cases:

i. Absence of inversion subject-predicate in a question introduced by an interrogative adverb:

whi fortune schulde with drawe here fauour fro me? $31 / 5$

ii. Inversion subject-predicate in:

penne is pi better pat is pi sougle free 21/5

iii. When more than one attributive adjunct qualifies a noun, one may precede and the other(s) follow:

sad man \& whizs $35 / 11$

homly folk $\&$ rude $13 / 14$

in leful pinges $\&$ lawfull $23 / 7$

rote pinges \& faylynge $3 / 7$

iv. The object to an infinitive occasionally precedes it:

pe sagis...kowde no keies fynde pis visioun to schewe 25/5

wepur is fairere to zeue cleernesse...or lizt to borwe $13 / 13$ 


\section{LIST OF WORKS CITED}

\section{DESCRIPIION OF ULC MSII.VI.39}

BROTHER BERNARD, The Threefold Gift of Christ, trans. and ed. by a religious of C.S.M.V., London, 1954.

Bernard, E., Catalogi Librorum Manuscriptorum Angliae et Hiberniae, 2 vols. in 1, Oxford, 1697.

Catalogue of the Manuscripts preserved in the Library of the University of Cambridge, ed. by Charles Hardwick and Henry R. Luard, 6 vols., Cambridge, 1856-67.

Doyle, A. I., 'A Prayer attributed to St. Thomas Aquinas', Dominican Studies, Vol. I, (July 1948), 229-38.

EMDEN, A. B., A Biographical Register of the University of Oxford to A.D. 1500, 3 vols., Oxford, 1957-59.

EMDEN, A. B., A Biographical Register of the University of Cambridge to 1500 , Cambridge, 1963.

Fristedt, S. L., The Wycliffe Bible, Part I. Stockholm Studies in English, no. 4, Stockholm, 1953.

FurNival, , F. J. (ed.), Hymns to the Virgin and Christ, E.E.T.S. O.S. 24, London, 1867.

GARDNER, H. L., 'Walter Hilton and the Authorship of the Cloud of Unknowing', R.E.S., IX, no. 34 (April 1933), 129-47.

GARDNER, J. E. G., The Cell of Self-Knowledge, London, 1925.

Goldschmidt, E. PH., Medieval Texts and their First Appearance in Print, London, 1943.

HoDgSON, PH., The Cloud of Unknoring, E.E.T.S. O.S. 218, 2nd ed., London, 1958.

hodgson, PH., Deonise Hid Diuinite, E.E.T.S. OS. 231, London, 1949.

HORSTMANN, c. (ed.), Yorkshire Writers: Richard Rolle of Hampole and his Followers, 2 vols., London, 1895.

horstman, c. (ed.), Nova Legenda Anglie, 2 vols., Oxford, 1901.

Hoste, A. (ed.), 'Dialogus inter Aelredum et Discipulum: An Adaptation of Aelred of Rievaulx De Spiritali Amicitia', Citeaux, X (1959), 268-76.

venn, J and venn, J. A., Alumni Cantabrigienses, Vol. I, From the Earliest Times to 1751, Cambridge, 1922. 
AdRIANus CARTHUsianus, Liber de Remedzis Utrnusque Fortunae prospere et adverse, Cologne, 1470 ?

Baron, H, 'Franciscan Poverty and Civic Wealth as Factors in the Rise of Humanistic Thought', Speculum, XIII (Jan 1938), 1-37

Baron, $\mathrm{H}$, The Crisis of the Early Italnan Renarssance, 2 vols, Princeton, 1955 BISHOP, MORRIS, Petrarch and his World, London, 1964

Bradshaw, $\mathbf{H}$, 'Two Lists of Books in the University Library' in Collected Papers of Henry Bradshaw, Cambridge, 1889, pp 16-54

BRIE, F . 'Mittelalter und Antike bei Lydgate', Englische Studien, 64 (1929), $261 \mathrm{ff}$ BURCKHARDT, J , Die Kultur der Renaissance in Italien, 1860

BusH, D , The Renarssance and English Humanism, Toronto, 1939

Cambridge History of English Literature, Vol I, Cambridge, 1912

DAUDIN, JEAN SEe ORESME, NICOLAS

Delisle, L, Anciennes Traductions Françaises du Traité de Pétrarque sur les remedes de l'une et l'autre fortune', Notices et Extrants des Manuscrits de la Brbliotheque Natronale, t XXXIV, 1re partie, Paris, 1891, pp 273-304 DEYermond, A D, The Petrarchan Sources of La Celestina, London, 1961 DILTHEY, w, Weltanschaung und Analyse des Menschen sert Renarssance und Reformalion, Gesammelte Schriften, II Band, Leipzig und Berlin, 1914 DoBson, s, Petrarch's View of Human Life, London, 1791 and 1797

DRAPER, w H . (trans), Petrarch's Secret or the Soul's Confluct with Passion, London, 1911

FERGUSON, w $\mathrm{K}$, The Renaissance in Histoncal Thought, Cambridge, Mass, 1948 Françon, M. 'Petrarch, Discıple of Heraclitus', Speculum, XI (April 1936), 265-71

FROMM, E, The Fear of Freedom, Routledge Paperback, London, 1961

galbraith, V H, 'John Seward and his Circle', in Mediaeval and Renarssance Studies, I, London, 1943, pp 85-104

Gallé, J $\mathbf{H}$, 'Een Nedersaksische novelle van Griseldis', Tıjdschrnft voor Nederlandsche Taal-en Letterkunde, IV (1884), 1-44

GARIN, E , Der Italienische Humanismus, Bern, 1947

heitmann, $\mathbf{k}$, Fortuna und Virtus Line Studie zu Petrarcas Lebenswershent Studı Italian1, Band I, Koln und Graz, 1958

huizinga, J , The Waning of the Middle Ages, Pelican Books, 1955

JAMES, M R, Descriptive Catalogue of the Manuscripts in the Library of Corpus Christ College, Cambridge, 2 vols, Cambridge, 1912

JAMES, Y R, The Catalogue of the Library of the Augustinian Friars at York in Fascaculus Ioannı Clark dicatus, Cambridge, 1909, pp 2-96

kORTing, G, Petrarcas Leben und Werke (Geschichte der Litteratur Italiens im Zertalter der Renaussance, Band I), Leipzig, 1878

KRISTELler, P o, Renatssance Thought, Harper Torchbooks, New York, 1960 KRISTEller, P o, Eight Philosophers of the Italian Renaissance, Stanford, Calıfornı, 1964

Lydgate, John, The Fall of Princes, ed H Bergen, E E T S E S, vols 121-24, London, 1918-19 
MarTin, A von, 'Petrarca und Augustin', Archrv fur Kullurgeschichte, XVIII (1928), 57-96

Martin, A Von, Soziologie der Renaissance, Frankfurt a M, 1949

martines, L, The Social World of the Florentine Renaissance, Princeton, 1963

oresme, nicolas, (for Jean Daudin), trans, Messire Françors Petracque des

remedes de lune et lautre fortune prospere et aduerse, Parıs, 1523

PENNINK, $\mathrm{R}$, Twee unt het Latın van pseudo-Petrarca en Petrarca vertaalde middelnederlandse novellen, Zwolle, 1965

PETRARCA, F , Opera, 2 vols, Venice, 1501

RAINE, J, the Younger, (ed), Testamenta Eboracensia, Surtees Socrety, Vol 4,

London, 1836

robertson, D w , JR, A Preface to Chaucer, Princeton, 1963

Robinson, J H , Petrarch, New York, 1908

saAZ, Johannes von, Der Ackermann aus Böhmen in A Bernt und K Burdach,

Vom Muttelalier zur Reformation, Band III, Te1l 1, 3, Berlın, 1917

SAlter, E, Chaucer The Knight's Tale and The Clerk's Tale, Studies in English

Literature, No 5, London, 1962

SAYLE, C, Annals of Cambridge University Library 1278-1900, Cambridge, 1916 SPEIRS, J , Chaucer the Maker, London, 1951

ThoRndike, I, Science and Thought in the Fifteenth Century, New York, 1929

TRINKAUS, C E, Adversity's Noblemen The Italian Humanists on Happiness, New York, 1940

TWYNe, тHOMAs, Phisicke against Fortune, London, 1579 (Translation of Petrarch's De Remedins)

WEISS, R, Humanism in England durtng the Fifteenth Century, 2nd ed , Oxford, 1957

weiss, R, 'An Unnoticed Manuscript of Humphrey, Duke of Gloucester', Bodleian Library Record, V (1955), 123-24

weiss, R, 'An English Augustinian in late fourteenth century Florence', English Miscellany, Vol 9 (1958), 1322

Whitfield, J H , Petrarch and the Renascence, Oxford, 1943

wilkins, E H, Petrarch's Later Years, Cambridge, Mass , 1959

WRIGHT, H G (ed), Morley's Translation of Boccaccio's De Clans Mulneribus,

E E T S OS 214, London, 1940

WYLE, NIKLAS VON, Translationen, herausgegeben durch Adelbert von Keller, Bibliothek des Litterarischen Vereins in Stuttgart, Band LVII, Stuttgart, 1861, pp 314-24 (Contains 'Trostung in Widerwartigkeit', a translation of dialogues 25 and 18 of the second book of Petrarch's De Remedins)

YPES, C, Petrarca in de Nederlandse Letterkunde, Amsterdam, 1934

zeitlin, J , The Life of Solitude, Urbana, Illinois, 1924 (Translation of Petrarch's De Vita Solitaria)

III LITERARY GENRE DIALOGUE AND CONSOLATIO

ADAm scotus OF DRYBURgh, Soliloquium de Instructione Animae Libri Duo, in $P L, t$ CXCVIII, col 843-72 


\section{LIST OF WORKS CITED}

Alanus de insulis, De Planctu Naturae in Th Wright, (ed), Anglo-Latin Saturcal Poets and Eprgrammatists of the Twelfth Century, vol II, London, 1872

Albertini, E, La Composition dans les Ouvrages Philosophrques de Sénèque, Paris, 1923

AUER, P A, Johannes von Dambach und die Trostbucher vom 17 bis zum 16 Jahrhundert, Beitrage zur Geschichte der Philosophie und Theologie des Mittelalters, XXVII, 1-2, Munster 1 W , 1928

BUSH, D , Paradise Lost in Our Time, Ithaca, 1945

cicero, Tusculan Disputations, trans J E King, Loeb Classical Library, 1945 cross, J E, 'On the Genre of the Wanderer', Neophalologus, XLV (Jan 1961), 63-75

Deschamps, eustache, Oeuvres Complètes, ed par le Marquis de Queux de SaintHilaire et Gaston Raynand, III Part, T x, S A T F , Parıs, 1878-1903

Favez, C, La Consolation Latıne Chrétzenne, Parıs, 1937

guillaume DE CONChes, Moraluum Dogma Philosophorum, ed J Holmberg, Uppsala, 1929

gUalteri ab insulis, Liber qui dicitur Moralum Dogma in Thor Sundby (ed). Della Vita e delle Opere di Brunetto Latın, Appendice Terza, Firenze, 1884 (The same work as the above)

HARNACK, A , History of Dogma, V, trans J Millar, 1894-99

HERFORD, $\mathrm{C} \mathrm{H}$, Studies in the Literary Relations of England and Germany in the Sixteenth Century, Cambridge, 1886

HiRzel, R, Der Dialog, 2 vols , Lelpzig, 1895

HOOPES, R, Right Reason in the English Renarssance, Cambridge, Mass , 1962

LEWIS, c s, The Discarded Image, Cambridge, 1964

martha, c, 'Les Consolations dans l'Antiquité' in Etudes Morales sur l'Anizquité, Parıs, 1883, pp 135-89

MARTIN LE FRANC, L'Estrif de Fortune et de Vertu, Paris, 1506

MERRILL, E, The Dialogue in English Literature, Yale Studies in English XLII, New York, 1911

migne, J P, Patrologiae Cursus Completus Series Latına, 221 vols, Paris, 1844-1903

PATCH, H R, The Tradition of Boethus, New York, 1935

PATCH, $\mathrm{H}$ R, The Goddess Fortuna in Mediaeval Literature, Cambridge, Mass, 1927

SENECA, De Remedis Fortuntorum in F Haase (ed), L Annaer Senecae Opera Quae Supersunt, Vol III, pp 446-457, Lelpzig, 1853

sundBy, T (ed). Albertan Brixiensis Liber Consolationis et Consilı, Chaucer Society, 2nd Ser, No 8, London, 1873

usк, тномаs, The Testament of Love in Chaucerian and Other Preces, ed W W Skeat, Oxford, 1897, pp 1-145

verhoeven, c , 'Filosofie van de Troost' in Rondom de Leegte, Utrecht, 1966, PP 51-81

watts, v E, 'Pearl as a Consolatio', Medium Aevum, XXXII (1963), 34-36

wendland, P, Philo und die Kynisch-Stousche Diatribe, Beitrage zur Geschichte der Griechıschen Phulosophie und Relıgıon, Berlın, 1895 


\section{LIST OF WORKS CITED}

Wilamowitz-MOEllendorff, u von, Antigonos von Karystos, Exkurs 3 Der Kynische Prediger Teles, Philologische Untersuchungen, herausgegeben von

A Kiesslıng und A von Wilamowitz, Viertes Heft, Berlin, 1881

WYCLIF, JOHN, Speculum Ecclesiae Milutantıs, ed A W Pollard, London, 1886

IV SOURCE-MATERIAL AND ANALOGUES

Achelis, h (ed ), Acta SS Never et Achiller, Texte und Unters zur Gesch der Altchristl Lit , Band 11, Leipzig, 1893

ADAM ScOTUS OF DRYBURGH, Solnloquzum de Instructione Animae Libri Duo in $P L, \mathrm{t}$ CXCVIII, col 843-72

ARISTOTLE, The Polutics With an English translation by $\mathbf{H}$ Rackham, Loeb

Classical Library, New York, 1932

ARNOLD, T, Select English Works of John Wyclif 3 vols, Oxford, 1869-71

AUgustive, The Caty of God, A Select Library of the Nicene and Post-Nicene

Fathers, Vol II, Buffalo, 1887

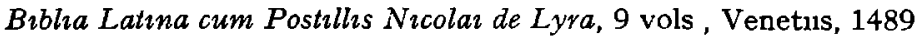

воетнius, De Consolatione Philosophrae ed H F Stewart and E K Rand, Loeb Classical Library, London, 1918

Bromyard, John, Summa Praedicantium, 2 vols, Venetus, 1586

BUltot, $\mathbf{R}$, La Doctrine du Mépris du Monde, Tome IV, Vol 2 Christianisme et Valeurs Humaines A Louvain, 1964

BURley, walter, De Vila et Monibus Philosophorum, ed H Knust, 2 vols, Stuttgart, 1886

curtius, E R, European Literature and the Latin Middle Ages, trans W R Trask, New York, 1953

FORSHALL, REV J and MADDEN, SIR F, The Holy Bible in the Earliest English Versions Made by $J$ Wycliffe and his Followers, 4 vols, Oxford, 1850

Francis, w Nelson, (ed ), The Book of Vices and Virtues, E E T S OS 217. London, 1942

Furnivall, F J (ed), Minor Poems of the Vernon MS, Part II, E E T S O S 117, London, 1901

Glossa Ordinaria, $P L$, t CXIV

GRLGORY, Homiliarum in Evangelia Libri Duo, $P L$, t LXXVI

GUILladme De machaut, Remede de Fortune in Oeuvres de Gurllaume de Machaut, tome II, ed Ernest Hoepffner, S A T F , Paris, 1911

HAASF, F, Index Lectionum in Universitale Vratislaviensi per hiemem a 1859

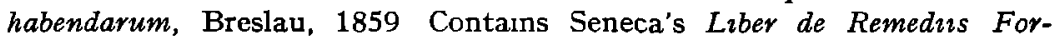
tuntorum

HARNACK, A, History of Dogma, V, trans J Millar, 1894-99

HOLE, C, English Sports and Pastımes, London, 1949

Holmstedt, G (ed ), Speculum Christrani, E E T S O S 182, London, 1929

innocentrus III, De Contemptu Mund2, $P L$, t CCXVII, col 701-46

JoHn chrysostox, The Homilzes on the Gospel of St Matthew, translated with notes by Sir G Prevost, 2 vols, 1838

juvenal, Juvenal's Satires in Juvenal and Persius With an English translation by G G Ramsay, Loeb Classical Library, 1912 


\section{LIST OF WORKS CITED}

LEFìvRE, Y , L'Elucidarum et les Lucrdaryes, Pans, 1954

Lydgate, John, The Legende of St Petronilla in Minor Poems, ed H N Mac-

Cracken, E E T S E S 107, Part I, pp 154-59

MOR RIS, R (ed ), Dan Mrchel's Ayenbute of Inwyt, E E T S O S 23, London, 1886 mustanoja, T F, The Good Wife Taught her Daughter, Annales Academiae

Scientiarum Fennicae, Series B, 61, 2, Helsinkı, 1948

owst, G R, Literature and the Pulpit in Medieval England, 2nd ed , Oxford, 1961 PAlmer, $\mathrm{R}$ G (ed). Seneca's De Remedus Forturtorum and the Elizabethans,

Chrcago, 1953 Contains the English translation by Robert Whyttynton

PLAto, Theaetetus, Sophist With an English Translation by H N Fowler, Loeb

Classical Library, 1921

RoBert of BRUNNE, Handlyng Synne, ed F J Furnivall, E E T S O S 119 and

123, London, 1901

ROBINSON, F N (ed). The Works of Geoffrey Chaucer, 2nd ed , Boston, 1957

SENECA, Ad Lucilium Epistulae Morales, trans Richard M Gummere, 3 vols,

Loeb Classical Library, 1917

STEElE, R (ed), Secreta Secretorum, Part I, E E T S E S 74, London, 1898

STRUTT, J, The Sports and Pastimes of the People of England, new edition by

W Hone, London, 1883

SUMmers, w c , Select Letters of Seneca, London, 1910

SURINGaR, W H D (ed ), Dit sign Seneka Leven, Leiden, 1895

thomas Palmeranus (hibernicus), Flores Doctorum, London, 1558

WETTWeR, A , Englischer Sport im 14 Jahrhundert, Gottıngen, 1933

\section{LANGUAGE, STYLE, AND PROVERBS}

ARISTOtle, Rhetornc, trans Th Buckley, Bohn's Classical Library, 1851

Baldwin, c s, Medieval Rhetoric and Poetic (to 1400), Gloucester, Mass, 1959. bebel, H , Proverbia Germanica, ed W H D Surıngar, Leiden, 1879

вонN, н G , A Hand-Book of Proverbs, London, 1885

CLEmoes, P, 'Liturgical Influence on Punctuation in Late Old English and Early

Middle English Manuscripts', Occaszonal Papers, 1, Department of Anglo-

Saxon (Cambridge 1952), pp $16 \mathrm{ff}$

Croll, m w , 'The Cadence of English Oratorical Prose', Studies in Philology, XVI (1919), 1-55

FuRNIVALL, F I (ed ), Hymns to the Virgin and Christ, E E T S O S 24, London, 1867

herRTAGe, SIDNEY, J H (ed), Catholicon Anglicum An English-Latin Wordbook dated 7483, E E T S OS 75, London, 1881

HodGson, PH (ed ), Deonise Hid,Diunnte, etc, E E T S O S 231, London, 1949 HODGSON, PH (ed), The Cloud of Unknowing, E E T S OS 218, 2nd ed, London, 1958

HORSTMANN, c (ed), Yorkshire Writers Ruchard Rolle of Hampole and his Followers, 2 vols, London, 1895

JORDAN, R, Handbuch der mittelenglischen Grammatı, Heldelberg, 1925, rev ed by Ch Matthes, 1934

KAISER, R, Medieval English, Berlin, 3rd rev ed. 1958 


\section{LIST OF WORKS CITED}

IIndholm, G, Studien zum mittellaternischen Prosarhythmus, Studia Latina Stockholmiensia X, Stockholm, 1963

LUICK, $\mathbf{K}$, Historische Grammatik der englischen Sprache, Lelpzig, 1914-40

Mcintosh, A, 'The Analysis of Written Middle English', TPS (1956), 26-55

KURATH, н and KUHN, s м (eds), Middle English Dictionary, Michigan, 1954-

Mayhew, A L (ed), Promptonum Parvulorum The First English-Latin Dictionary, E E T S E S 102, London, 1908

Moore, S, MEech, S B and whitehall, H, 'Middle English Dialect Characteristics and Dialect Boundaries', Essays and Studies in English and Comparatıve Literature, Michugan (1935), 1-60

MURRAY, J A H, BRADLCY, H, CRAIGIE, W A and onions, $\mathrm{C}$ T (eds), The Oxford English Dictionary, 12 vols plus supplement, Oxford U P , 1933.

Mustanoja, T F, A Middle English Syntax, Part I, Helsinki, 1960

отто, A , Die Sprichwörter und sprichwortlichen Redensarten der Romer, Leipzig, 1890

PHILlipps, $x$ c. 'Adverb Clauses in the Fifteenth Century', Enghsh Studies, XLVII, No 5 (Oct 1966), 355-65

samuels, m L , 'Some Applications of Middle English Dialectology', English Studies, XLIV, No 2 (April 1963), 81-94

SINGER, s, Sprichwörter des Mittelalters, 3 vols , Bern, 1944-47

Smith, william geORge, The Oxford Dictionary of English Proverbs, 2nd ed rev by Sur Paul Harvey, Oxford, 1952

stratuan, F H, A Middle English Dictionary, new ed by Henry Bradley, Oxford, 1891

TAyloR, A, The Proverb and an Index to the Proverb, Copenhagen, 1962

TEMPest, N R, The Rhythm of English Prose, Cambridge, 1930

VISSER, F TH, A Syntax of the Language of St Thomas Move, Materials for the Study of the Old English Drama, Vols 19, 24, and 26, Louvain, 1946, 1952, and 1956

visser, F TH , An Historical Syntax of the English Language, Parts I and II, Leiden, 1963 and 1966

DE VRIES, F C (ed ), Floris and Blauncheflur, Groningen, 1966

WERNER, J, Lateinische Sprichwörter und Sinnspruche des Mittelalters, 2nd rev ed by Peter Flury, Heidelberg, 1966

WYLD, н C , A History of Modern Colloqunal English, 3rd rev ed , Oxford, 1936 WYLD, H C, $A$ Short History of English, 1914, 3rd ed 1927 


\section{GLOSSARY}

N B This glossary aims at giving all the words and spelling variants occurring in the text Words not recorded in the standard dictionaries, or not recorded in the sense they have in this text, are provided with a note See also the section on Vocabulary where they are listed together A list of words recorded in OED and MMED with earliest dates posterior to the presumable date of the treatise can be found there also

Note that 3 follows $g$ Words beginning with $\imath$ or $g$ have been classed together under $\imath$ Under $v$ are similarly classed together words beginning with the vowel or the consonant according to their spelling in the text $p$ follows $t$

In the etymological notes, which are necessarly brief, I have sometimes included the WS form, though in general it is evident from the East Midland complexion of the language that the OE Anglian forms should be regarded as the ancestors of the forms in the text In the case of WS $\bar{e}^{1}$ the Anglian form with $\bar{e}$ precedes the WS form with $\overline{\mathscr{e}}$

A

a, interj ah, 29/5

$a, a n$, art (OE àn) a, an, passim abelte, sb (OF ableté) aptitude, 5/37

$a$ brde, vb (OE àbIdan) abrde to pou seende expect you to get, 39/20, abiden, pp looked forward to, $15 / 10$

$a$ boute, adv (OE onbūtan) about, $31 / 15$

abstrnence, sb (OF \& L) 1d, selfdenıal, $37 / 21$

acceptable, adj (OF \& L) pleasing, agreeable, 15/4, 41/5

a corden, vb pr pl (OF acorder) are of one mind, $25 / 9$

a countes, sb (OF aconte) accounts, $19 / 13$

a queynted, adj (OF acointier) acquainted, $27 / 8$ aduersite, sb (refashioned from $O F$ aversite) adverse fortune, passim

a ferd, adj (OE āfëran, āfǣran) afraid, $27 / 5,37 / 19$

affeccions, sb pl (OF \&L) inclinations, desires, 31/26

afiaunce, $\mathrm{sb}$ (OF) hadde sich afiaunce, inspired so much confidence, $25 / 25$

affluens, sb (OF) abundance, 29/14

affter, per affter, prep (OE after) accordingly, 25/22, after, prep adv , for, in prey after, 9/22, loken after, $31 / 22$, afterward, adv afterwards, $5 / 28$

a gast, ad] (OE ḡ̄stan) terrıfıed, $27 / 13$

age, sb (OF) age, 3/7

$a$ zen, adv (OE ongegen) again, 31/22, 
a zen, prep against, 19/10, a zenes, prep, 31/33, a zens, prep, 7/20, azenward, adv conversely, 13/21, a zeyn, prep, 3/30

aire, $\mathrm{sb}$ (OF) air, 31/10, eire, 31/9

alderest, adv (OE ealra, ælra + -est, forms an absolute superlative in combination with an adjective) most, $27 / 26$

aluene, adj (OF) some one else's, 19/7, alnene goddes, false gods, $19 / 6$

alle, adj adv, (OE all, eall), all, 13/28, alle pe hole, the whole, 13/9, alle one, alone, $11 / 23,31 / 8$, alle only, solely, $35 / 12$, al only, solely, 41/15, alone, alone, $3 / 21$

als, conj ( $\mathrm{OE}$ eall, all swã) as, 31/13, $33 / 5$, al so, conj, as, $7 / 3$, also, adv also, $41 / 16$

altutude, sb (OF) he1ght, 5/27

al poow see pot

alwey, adv (OE ealne weg) always, in every respect, 9/7, 15/25

among, prep (OE on gemang) amid, among, 13/8, a mong. 37/20, a mong, adv contınually, $37 / 18$

amyable, adj (OF) lovable, propitious, $39 / 10$

an see and

and, conj ( $\mathrm{OE}$ and) and passim, if, $35 / 9,41 / 15$, an, and, $27 / 17$

anempirs, prep (OE on + efen) as regards, 23/10

angry, adj (ON angr $+y)$ angry, $39 / 33$

a non, adv (OE on āne, on ān) at once, $41 / 13$

answerede, pa $3 \mathrm{sg}$ (OE andswarian) answered, 9/24, 29

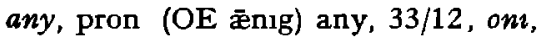
$35 / 11$, ony, $3 / 28$

apostele, sb (OE apostol) apostle, 9/15 , apostle, 7/19

appeinte, sb (OF) appetite, 39/25

apt, adj (L) suitable, fit, 5/36, 7/15

a rarzeth. pr $3 \mathrm{sg}$ (AF arayer) arrays, $15 / 3$ are, aren, art, arn see $b e, \mathrm{vb}$

arest, sb (OF) restraint, control, 9/7 asaule, inf (OF asaillır) attack, 3/4, asailed, pp 9/3

asaye, $\mathrm{pr} 3 \mathrm{pl}$ (AF assa1er, essa1er) try, $37 / 22$

ascende, inf (L) clumb, rise, 13/26, $31 / 19$

a schamed, adj (OE asceamod) ashamed, 15/13, 24

askyng, vbl sb (OE ascunge) request, 9/23

asonled, PP (OF assoller) absolved, relieved, 23/9

aspied. Pp (F espier) discovered, seen, $11 / 9,39 / 15$

assent, sb (OF) consent, 31/35

assis, sb $\mathrm{pl}$ (OE assa) asses, 15/17

ast, pa 2 sg ( $\mathrm{OE}$ ascian) ask, 15/14

at, prep (OE æt) at 33/10, per atte, present, 35/2

auarze, sb (OF) avarice, greed, 31/27

auer(e), sb (AF) possessions, wealth. $33 / 21$ and note

aunceleres, $\mathrm{sb} \mathrm{Pl}$ (OF ancestre) ancestors, $13 / 12$

a wey, adv (OE on weg) away, 19/27, 27/15, 39/19

awte, hym awte, pr $3 \mathrm{sg}$ impers (OE āhte) ought to, 39/12

\section{B}

babe, sb (nursery word, ME) baby, $15 / 21$

badde, adj. (OE bæddel) bad, worthless, $15 / 11$

bakers, sb gen sg (OE bacere) baker's $39 / 21$

balle, sb (ME) ball, 31/20, 21

banges, sb $\mathrm{pl}$ (ON banke) banks, dikes, see see banges

baptım, sb (OF baptesme) baptısm, $15 / 7$

bave, ad) (OE bær) destıtute, uncovered, 27/26

bareyne, adj (OF baraine) barren, devord, $21 / 12$ 


\section{GLOSSARY}

barly, sb (OE bærllc) barley, 39/20

bate, sb (aphetic form of OF debate) quarrel, discord, 37/7

bateilles, sb $\mathrm{pl}$ (OF batalle) battles, $29 / 2$

$b e, \mathrm{vb}$ inf (OE bẽon) to be, 3/1,29, bee, inf , 33/14, ham, pr $1 \mathrm{sg}, 3 / 19$, $5 / 11$, art, pr $2 \mathrm{sg}, 7 / 9,9 / 20,2 s$, pr $3 \mathrm{sg}, 3 / 20,21$, be, pr pl , 35/14, ben, pr pl, 3/32,21/5, ave, pr pl , $31 / 35$, aren, $\mathrm{pr} \mathrm{pl}, 31 / 26$, arn, $\mathrm{pr}$ $\mathrm{pl}, 9 / 17$, be, pr subj $2 \mathrm{sg}, 3 / 30$, $35 / 11, b e, \mathrm{pr}$ subj $3 \mathrm{sg}, 33 / 12,7 / 26$, be, imper sg, $11 / 5$, be, imper $\mathrm{pl}$, $23 / 6$, whas, pa $1 \mathrm{sg}, 11 / 4,15$, was, $3 / 11,21 / 14$, were, pa $2 \mathrm{sg}, 31 / 19$. $35 / 17$, where, pa $2 \mathrm{sg}, 11 / 13$, ware, pa $2 \mathrm{sg}, 19 / 12$, was, pa $3 \mathrm{sg}, 3 / 1,3$, were, pa subj $3 \mathrm{sg}, 39 / 15$, were, pa $\mathrm{pl}, 33 / 22,11 / 18$, weren, pa $\mathrm{pl}$, $33 /$ note to 121

$b e$, prep (OE bi) by, through, 3/6, $39 / 6$, be per one, alone, 33/16, bi, adv, 35/6, by, adv, 39/18

be cause pat, conj (be + cause) because, $11 / 11,25 / 27$

bed, sb (OE bedd) bed, 15/22, 27/29, bedde, 37/26

beden, PP (OE biddan and OE bëodan) ordered, 5/26

$b e e$, inf see $b e, \mathrm{vb}$

bee, $\mathrm{sb}$ (OE bẻo) bee, 5/18

beeste, sb (OF beste) beast, 37/11. bestes, sb pl , 39/7

be for(e), prep of place (OE beforan) before, $7 / 29,33 / 20$, before, prep of order, $33 / 27$

beginnynge, vbl sb (OE beginnan $\perp$ -lng) beginning, 15/9

behap, adv (be + ON sb hap) perhaps, $3 / 25$

be hight, Pp (OE behēht) promised, $35 / 25$

bell, sb (OE belig) belly, 7/29, beln seruaunt, (not in OED or MMED) belly-slave, 39/26 bemes, sb pl (OF bēam) beams, rays, $13 / 17,31 / 9$

be neme, $\mathrm{vb}$ inf (OE benæman or beniman) deprive, $3 / 7$

bere, inf (OE beran) carry, bear, 7/15 . berest, pr $2 \mathrm{sg}, 27 / 27$, berist, pr 2 sg, 27/27, beryng, vbl sb behaviour $25 / 31$, bore, pp born, 3/1, 21/14, born, pp born, $3 / 11,15,21 / 16$

besi, adj (OE bysig) diligent, assiduous, $21 / 10$, bisily, adv , 7/30

besom, sb (OE besma) broom, 19/26

best, adj (OE betsta) best, 31/30; for his beste, for his best interests, $9 / 26$, best, adv (OE betest) best, 23/15

bestes see beeste

beten, PP (OE bẻatan) beaten, 25/28 beteve, adj comp (OE betera) better. $9 / 2,23 / 36$, betere, adv comp (OE betere) better, $37 / 24,39 / 19$, better, adj comp , 21/5, bettere, adj comp . 7/13, 9/34

be tide, inf (ME) happen, befall, 25/20

be tokenep, pr 3 sg (OE tācnian) sıgnifies, symbolizes, $41 / 14$

be trappid, pp (OE betræppan) ensnared, 21/17

better(e) see betere

beuzte, sb (OF beaute) beauty, 3/12, bewte, 3/27

$b i, \mathrm{adv}$ see $b e$

bıddyngges, sb (OE biddan + ing) orders, $23 / 35$

bızere, sb (OE bycgan + er) buyer, $23 / 26$

binyn, sb (OE binnan) inside (this substantival use not in OED or MMED), 23/4

birthe, sb (ON *byrpr) burth, 17/1; brrpe, 13/1, 19/1

birthen, sb (OE byrpen) burden, 7/33; birpen, 23/26, burpen, 5/13

bischops, sb gen sg (OE bisceop) bishop's, 31/23

bisıly see besı

butınge, pr p (OE bitan) stıngıng, 9/15 
bitter, adj (OE biter) bitter, 37/23, $41 / 7$, buttur, $9 / 10$

blamynge, vbl sb (OF blamer, blasmer) censure, criticism, 19/6

blessid, pa 3 sg (OE gebletsian) blessed, 33/25, blessid, ad] (OE gebletsod) blessed, 33/29

bleu3, pa 3 sg (OE blāwan) blew, $39 / 32$

blisse, sb (OE blis) happiness, 29/1

blod, sb (OE blōd) blood, 13/5

blosme, sb (OE blōstm) blossom, 3/27

bodr, sb (OE bodig) body, 3/9, 22 , body, 5/16, 25/9

bond, sb (ON band) tie, fetter, 21/9, $35 / 9$

bondache, sb (AF bondage) servitude, bondage, 21/1,23/30, bondage, 21/3

bonde, $\mathrm{sb}$ as adj (OE banda, ON bōnde) bore bonde born into servitude, $21 / 14$, boonde in servitude $21 / 2$

bord, sb (OE bord) board, table, 39/13

bore, born see bere

borwe, inf (OE borgian) borrow, 7/25, borwed, pp 3/32, borwyng, vbl sb, $29 / 11$

bost, sb (etym uncertain, "behāst?) boast, bragging, 37/8

bothe and, adv (ON bāpar) both and , 33/25, bope, pron both, $15 / 18,35 / 19$

bounde, pp (OE bindan) bound, 9/17

brak see breke

braunches, sb pl (F branche) branches, $13 / 6$

bred, sb (OE brēad) bread, 37/18, $39 / 20$

brefnes, sb (OF bref + nes) shortness (of size), this use not in OED or MMED, 5/23

breke, inf (OE brecan) break, 27/14, $35 / 9$, brak, pa $3 \mathrm{sg}, 25 / 28$

bren, inf (ON brenna, OE bærnan) to burn, intr, 39/37

bridel, sb (OE bridel) bridle, 9/7

brizt, adj (OE beorht) bnght, 13/17, bryghter, comp , 5/8, bry 3 tnesse, 11/8 bringith see brynge

brode, adv (OE brād) wide, far, 31/10 brondes, sb $\mathrm{pl}$ (OE brand) fire, burning, $3 / 6$

broth, sb (OE brop) broth, 37/22

bropur, sb (OE brōpor) brother, 3/25

brouzt(e), broughte see brynge

bryztnesse see brizt

brynge, inf (OE bringan) bring, persuade, 27/20, bringith, pr 3 sg brings, causes, 39/27, brouzt, pa pl , 13/14, brouzte, pa pl, broughte for $p$, pa $3 \mathrm{sg}$ (OE forpbringan) gave birth to, $29 / 11$

burpen see birthen

but, adv (OE būtan) only, 3/27, 5/4, but, conj but, 11/23, 15/20, but pat, conj but, 5/21, but $32 f$, conj unless, $7 / 19$

buxum, adj (OE būhsum) humble, obedient, 25/19

$b y, a d v(O E \mathrm{bl}) \mathrm{by}$, see be

byndere, sb (OE bindan + er) binder, $25 / 8$

\section{C}

calles, pr $2 \mathrm{sg}$ (ON cf OI kalla, but cf LOE ceallian) call, 27/3, callıd. pp 15/5, kald, pp 13/10

capinf, adj sb (ad $L$ captivus of OF chaitıf) enslaved, captıve, 25/6

carnage, sb (AF of CF chariage) burden, load, 5/12

cause, sb (OF cause, L causa) cause, ground, 5/12, 9/29

causen, pr $\mathrm{pl}$ (OF causer of ML causarc) cause, bring about, 41/1

certern, adj (OF) be certern make sure, $35 / 4$

certes, adv (OF), 25/14, certus, 21/12, certannly, surely

cete, sb (OF cité) city, 11/21, pl cetes, $11 / 20$

chalis, sb (OF chalice \& $\mathrm{L}$ calicem) chalice, cup, $23 / 3$ 


\section{GLOSSARY}

charche, sb (OF charge) burden, $23 / 24$, no gret charche, of little $1 \mathrm{~m}$ portance, $35 / 8$

charched, PP (OF charg(1)er) burdened, loaded, 23/29, 27/22, taken into account, $19 / 7$

charnte, sb (OF charité) divine grace, $5 / 6$

chast, ad] (OF chaste) chaste, pure, $3 / 24$

chastesinge, vbl sb (OF chastıer) correction, punishment, 27/19

chateren, pr pl (imutative) chatter, $31 / 4$

chaumbre, sb (OF chambre) chamber, $21 / 10$

chaunchable, adj (OF changeable) unstable, variable, $31 / 13$

chaunge, sb (OF cha(u)nge) change, $23 / 17$

chere, sb (OF chiere, chere) with a lawyng chere cheerfully, 39/17, heuy chered sad faced, 27/7

chese, inf (OE cc̄osan) decıde, choose, $37 / 16$, chese, pa $3 \mathrm{sg}, 11 / 19$, chosen, pp 33/9, chosen, adj (Pp of $\mathrm{OE}$ cēosan) excellent, select, 9/21

chrld(e), sb (OE culd) child, 15/22, $15 / 1$, pl childer, 9/11, children, 13/22, childrin, 33/22, childryn, $15 / 3,33 / 28$

cleernesse, sb (OF cler + nes) splendour, 13/13, clernesse, 5/7

clenly, adv (OE clānlīc) cleanly, neatly, $15 / 3$

clennesse, sb (OE clānnes) purity, innocence, $3 / 9$

clerk, sb (OE clerc, clenc, OF clerc) scholar, author, student, 23/34, clerkes, $\mathrm{pl}, 37 / 20$

cleyme, inf (OF clamer, st claım-) to claim, $15 / 8$

climbe, pr subj 2 sg (OE clımban) climb, 31/16

clips, sb (aphetic form of OF eclipse) deprivation, 13/22. cloistre, sb (OF cloistre, clostre) cloister, 25/32

clothed, PP (OE clāpıan) clothed, $27 / 25$, cloped, clopid, pp 27/23, $5 / 6$, clopith, pr $3 \mathrm{sg}, 31 / 9$

clopes, sb pl (OE clāp) clothes, 15/22, $39 / 29$, clopis, $13 / 30$

colt, sb (OE colt) colt, 9/13

comaundede, pa $3 \mathrm{sg}$ (OF comander) commanded, $23 / 8$

come see komen

comen, adj (OF commun) common, general, 31/25, comyn, 37/20, comynly, 5/14, comen law common law, the general law (of the Church), $19 / 17$, see note

comendable, adj (L) prasseworthy, $33 / 26$

comendid, pp (L comendare, OF comender) praised, complimented, $3 / 17$

compelluth, pr 3 sg (OF compeller) compels, 39/10

comytte, imp sg (L committere) commit, entrust, $9 / 32$

condicions, sb (OF \& L) dispositions, habits, 31/7, condiczoun, nature, condition, 13/3, 15/1

confecciones, sb $\mathrm{pl}$ (OF confeccion) dishes containing fruit and spices, $27 / 10$

conserl, sb (OF concile, consel) judgment, ability to advise, $7 / 1$. conserlle, secret, $7 / 18$, conserlles, conferences, meetings, 23/20

conserlle, inf (AF cunsiler, CF conseillier) consult, seek advice, 39/1 conseruede, pa $3 \mathrm{sg}$ (OF conserver) protected, 9/15

consideracion, $\mathrm{sb}(\mathrm{OF} \& \mathrm{~L})$ thought, attention, 39/26

constaunt, adj (OF) steadfast, constant, $31 / 15$

constrerne, inf (OF) compel, force, $31 / 14$, constreyne $b$, pr $3 \mathrm{sg}, 39 / 11$ contemplacion, sb (L \& OF) contemplation, 23/30 
contempinble, adj (L \& OF) contemptible, disgraceful, $3 / 21$

content, adj ( $\mathrm{pp}$ of contenten, $\mathrm{F}$ contenter) content, 39/30

contynuely, adv (F continuel) continually, 31/21

contrarze, adj (CF contrarié) contrary, opposed, 23/9

contricion, $\mathrm{sb}(\mathrm{L} \mathscr{F} \mathrm{OF})$ contrition, remorse, $41 / 2$, contricioun, $41 / 1$

contrite, ad) ( $\mathrm{L}$ contritus, $\mathrm{pP}$ of conterere) remorseful, contrite, $41 / 6$

conuersacioun, sb (L \& OF) company, $19 / 12$

coprous, adj (L $\&$ OF) plentıful, abundant, $9 / 19$

corn, sb (OE corn) corn, 9/9, cornes, crop, 29/3

corowned, pp (OF coroner) crowned, $33 / 10$

cors, sb (OF cors) body, 5/7, 12

cros, sb (OE cros from OIr cros, ult1mately L crux-cruc1s) cross, $41 / 14$

corupt, PP (L corruptus) destroyed, $3 / 7$

coseyn, sb (OF cosin) cousin, 15/7

couden see kun

couente 5, pr 3 sg (OF coveitier) desires greeduly, 33/6

couetrse, $\mathrm{sb}$ (OF covertise) covetousness, greed, $33 / 4$

couentous, adj (OF covertus) covetous, greedy, 31/14

cradel, sb (OE cradol) cradle, 15/20

crafti, adj (OE craftig) clever, ingenuous, $3 / 31$

crasche, sb (OF crache) manger, 15/20

creature, sb (L creātūra \& OF criature) creature, person, 33/31

crime, sb (OF crume \& $\mathrm{L}$ crimen) crime, sin, 19/7

cubites, sb pl (L cubitum) cubit (length of fore-arm 18-22 ins), 5/29

cumpanye, sb (OF compa(1)gnie) company, 33/19

cuntre, sb (OF cuntrée) country, 11/3, 4,6, kuntre, 27/15 cure, sb (OF cure) cure, 9/32

curteynes, sb pl (OF cortıne) curtains, $15 / 22$

D

daies, sb $\mathrm{pl}$ (OE dag, $\mathrm{pl}$ dagas) days, $5 / 4$, on dares, in day time, $31 / 9$

dame, sb (OF dame) dame, lady, 15/3, $21 / 12$

damesele, sb (AF dameisele, L domicella) young woman, $3 / 25$

daunger, sb (AF daunger) domination, power, $25 / 12$

debate, $\mathrm{sb}(\mathrm{OF})$ at debate in conflict with, $3 / 22$

debıllte, sb (OF debılıté $\&$ L dēbılıtās) physical weakness, $7 / 21$

deceyued, $\mathrm{PP}$ (AF cf $\mathrm{CF}$ decevour) decelved, 31/25

decre, sb (OF, var of decret) edict, decree, $19 / 16$

dede see do

dedes, sb pl (OE dēd, d̄̄d) actıons, $19 / 6,33 / 30$

dedli, adj (OE dēadlic) deadly, mortal, transitory, 19/2, dedly, 35/19

defıle, inf (OF de + OE fỹlan) pollute, defile, 35/6, defiluth, pr $3 \mathrm{sg}$, $3 / 22$

deformute, $\mathrm{sb}$ (OF deformité) uglıness, deformity, 3/5, 22

degre, sb (OF degré) rank, position, $7 / 14$

del, sb (OE dæi) sum del, somewhat, $29 / 14$

dele with, pr 1 sg (OE dælan) have to do with, 39/35

delentable, adj (OF delitable, deleıtable) pleasant, delightful, 13/5

delıcacıes, sb pl (L dēlıcācıa) fine foods, delicacies, 39/23

delıcate, adj (L dēlıcātus) fastıdıous, voluptuous, 39/25

delnces, sb pl (OF delice) joys, 23/31, delights, sensual pleasures, 41/1

delizt, sb (OF delite) pleasure, delight, $3 / 4$, delıt, $7 / 7,37 / 18$ 
delnuere, inf (OF delivrer) release, set free, 25/15, deluuerid, pp $11 / 2$

deme, ımp sg (OE dēman) decide, judge, 13/12, demed, pp 15/10. demen, inf think, 27/16

denyed, pp (OF denwer) denied, refused, $13 / 8$

departıp, pr $3 \mathrm{sg}$ (OF departur) separates, 35/3, deperti $p, 9 / 9$

depe, ad] (OE déop) deep, 13/5

deposed, pp (OF deposer) deposed, $33 / 11$

dere, adj ( $\mathrm{OE}$ dēor) beloved, dear, $35 / 11$

derk, adj (OE deorc) dark, 11/9, derke, $13 / 5$

derst see per, vb

descounfed, inf (OF desconfit, pp of desconfure) to overcome, $15 / 23$

desese, sb (OF desaise, disease) sufferıng, misery, 33/33

desıye, inf (OF désırer) desıre, 35/23, desiven, pr $3 \mathrm{pl}, 27 / 32$

desir(e), sb (OF desir) desire, 5/31, 33/8 despit, sb (OF) I ham had in despit, I am despised, 3/19

deth, sb (OE dēap) death, 3/14, 7/5, dep $\bar{p}, 35 / 24$

deuouzt, adj (OF devout \& L dēvōtus) pious, $37 / 16$

deynte, sb (AF deinté \& CF deintie) pleasure, honour, 13/19, deyntees, pl delicacies, titbits, $37 / 18$, deyntes, pl $39 / 35$

dize, inf (ON, ef OI deyja) to die, $7 / 26, d_{2} z e$, pr subj $2 \mathrm{sg}, 19 / 2$

dignify, inf (OF dignefiler) to honour, exalt, $21 / 11$

dignite, sb (OF dignité) high esteem, high rank, position of honour, 13/7, $29 / 10$

discharched, pp (OF deschargier) relieved from, 23/19

discrecioun, sb (ML \&. OF) rational perception, $21 / 7$

disperr, sb (AF desper) despair, $25 / 13,14$ dispisith, pr $3 \mathrm{sg}$ (OF despis-, stem of despire $\&$ despisier) despises, looks down on, 35/13, 15, dispisip, 35/14, $39 / 18$

displesaunce, sb (OF displaisance) displeasure, annoyance, 21/16

displese, pr subj 3 sg (OF desplaus-, full stem of desplarre) displease, annoy, $31 / 2$

dispose, inf (OF disposer) arrange, ordain, $9 / 34$

diuerse, adj (L diversus \& OF divers(é)) different, varıous, 19/15

diunnte, sb (OF divinité) theology, $37 / 10$

do, inf (OE dōn) do, 11/6, 25/19, don, pp (OE gedōn) done, 23/1, 31/2, dost, $\mathrm{pr} 2 \mathrm{sg}, 13 / 9$, dop, pr $3 \mathrm{sg}$. $7 / 21$, doth, pr $3 \mathrm{sg}, 23 / 28,39 / 10$, dede, $\mathrm{pa} \mathrm{sg}, 19 / 5$

doctour, sb (L $\& \mathrm{OE})$ churchfather, $5 / 10$

dole, sb (OE dāl) alms, dole, 31/23

domes day, sb (OE dōmes dæg) judgment day, doomsday, 19/13

dore, sb (OE duru) door, 35/5

dost, doth, dop see do

douzblet, sb (F doublet) close-fitting jacket, doublet, 37/26

douzteles, adv (OF doute + les) without doubt, 9/33

doun, adv (OE ādūne) down, 27/21. $31 / 22$

dowter, sb (OE dohtor) daughter, $3 / 25,9 / 28$, dowteres, pl $35 / 13$

drank see dryngen

drawe, pr $3 \mathrm{pl}$ (OE dragan) drawe next to resemble, $7 / 14$

dreden, pr 3 pl (OE ondrēdan, dridan) dread, 29/2

drinke, sb (OE drinc, drinca) drink, 9/10, 33/24, drynk, 39/5

druce, inf (OE drifan) drive, 39/19

drunken, adj (pp of OE drincan) drunk, 37/9

dryngen, inf (OE drincan) to drink, $41 / 12$, drank, pa $2 \mathrm{sg}, 23 / 3$ 
drynk see drinke

dulwentted, adj (OE dol, dylle + gewit + ed) dulwitted, $7 / 13$

dures, sb (OF durece) hardness, sever1ty, 25/18

dymmere, adj comp (OE dım) obscurer, $11 / 8$

dyuors, sb (OF divorce) separation, divorce, $35 / 3$

E

ebbith, pr 3 sg (OE ebbian) ebbs, $31 / 12$

ech, pron (OE æghwhulc, æilc) each, every, 19/6, eche, 19/6

eire see aire

elles, adv (OE elles) else, otherwise, $35 / 11$, elles (used elliptically) something else, 9/33

emperour, sb (OF empereor, L $1 \mathrm{~m}$ perātor) emperor, 5/22, $15 / 6$, emperours, pl , 13/23

encrese, Imp sg (AF encress-, L increscere) increase, $5 / 32$, encresis, pr $2 \mathrm{sg}, 5 / 32$

ende, sb (OE ende) end, 15/10, endes, $\mathrm{pl}, 35 / 19$, endeles, ad] (OE endelēas), endless, $19 / 15,21 / 17$

ende $\bar{p}$, pr $3 \mathrm{sg}$ (OE (ge)endian) ends, $25 / 22$

enduet, pp (AF enduer) endowed, provided, $5 / 7$

enemye, sb (OF enemi) enemy, 3/3, $7 / 21$

enforce, imp sg (OF enforcier) exert, $19 / 11$

enformede, pa 3 sg (OF enformer) advised, instructed, 9/31, enformeth. pr $3 \mathrm{sg}$ instructs, $5 / 9$

ennoynted, PP (from OF PP enoint) anointed, 5/28, ennoyntede, pa $3 \mathrm{sg}$. $15 / 18$, enoynten, inf , $5 / 25$

en presound, pp (OF enprisoner) imprisoned, $25 / 27$

ensaumple, sb (AF ensample) example, model, 33/13

ent2rdyte, adj PP (OF enterdit, sb \&
OF entredit, pp of entredure) forbidden, prohibited, 19/21

entre, sb (OF entrée) admittance, access, $33 / 26$

enuye, sb (OF envie) enmity, 27/12

ere, sb $\mathrm{pl}$ (OE ēare) ear, 23/6, eres, pl $37 / 22$

erthely, adj (OE eorplic) earthly, 23/33, erpeli, $19 / 19$

erpe, sb (OE eorpe) earth, 23/1, 32, erthe, $23 / 17$

ete, inf (OE etan) to eat, 39/31, eten pr $3 \mathrm{pl}, 39 / 7$

euen, adv (OE efne) even, 39/23

euene, adj ( $O E$ efen, efn) equal, $7 / 10$

euenehelde, $\mathrm{ad}_{1}$ as $\mathrm{sb}$ ( $\mathrm{OE}$ efeneald or efen $+s b$ eldu) of the same age, co-eval, $7 / 10$

eueve, adv (OE æ̈fre) always, ever, $5 / 9,15 / 2$, eusere $p e$ pe the the, $35 / 19$

euyere see heuy

excusable, adj (L $\mathcal{G}$ OF) excusable, 13/15

exiled, pp (OF exulıer, ML exılıāre) exiled, deprived, 5/9

expedient, adj ( $\mathrm{L}$ expedientem, OF expedient) profitable, 9/30

experience, sb (OF experience, L experientia) experience, 33/23, experiens, $3 / 32$

expunses, $\mathrm{sb} \mathrm{pl}$ (L expensa, OF expense) expenses, $35 / 3$

eyze, sb (OE èage) to $p e$ eyze, to the view, 5/13, enzen, pl 33/20, eyzen, $\mathrm{pl}, 37 / 11$

\section{F}

face, sb (OF face) face, $3 / 13$

fader, sb (OE fæder) father, 9/7, 19/17, faderes, gen sg, 15/17, faderis, gen sg, 15/17, faderles, ad] (OE fæderleas) fatherless, 33/22

farle, inf (OF faillir) faul, dre, 39/6, farle $p$, pr 3 sg fals, is deficient, $7 / 7, \operatorname{fal} h p$, pr 3 sg lacks, 21/12, fanl $p$, pr $3 \mathrm{sg}$ decays,faylıth, pr 3 
sg is wanting, 33/5, taylynge, $\mathrm{pr}$ part , defective, decaying, $3 / 8$

farr, adj (OE fæger) beautiful, 3/13, fanre, 3/29, 5/3, teyre, 15/21, fayr, 27/20, farre fetoured (from OF farture, feture) well bult, handsome, 3/9, farrehed, beauty, 15/7, fairenes, beauty, $3 / 14$, fairere, comp more beautıful, 13/12, fairnes, $3 / 23$, fayrnesse, $5 / 1$ beauty

falle, $\mathrm{sb}$ (OE feall) fall, 11/14

falle, vb pr pl (OE fallen, feallan) fall, 5/1, falle, inf, 23/21, falle, Imp sg $15 / 7$

fals, adj (OF fals) deceitful, untrustful, 25/26, disloyal, 25/27, false, faulty, 31/25, falsly, adv unjustly, $25 / 27$, falsnes, sb deceitfulness, $33 / 17$

fame, sb (OF fame) fame, 5/24, 11/8 famouse, adj (AF, \& L famōsus) celebrated, renowned, 11/22

famylzar, adj (OF famlier) belonging to one's household, 7/21

fare, sb (OE faru, fær) sustenance, food, $37 / 1,16$

farist, pou farist harde, pr 2 sg (OE faran) you are il fed, 41/9

faste, adv (OE fæste) loudly, 31/4, tightly, furmly, 31/26, greatly, $35 / 18$, quickly, $37 / 8$

faueve, $1 \mathrm{mp}$ sg (OF favorer, faveurer) support, 9/2, fauernnge, pr part supporting, 19/14

fauour, sb (OF favor, favour) favour, $31 / 6$

fawty, adj (from OF faute) faling in duty, censurable, 9/8

fayluth, faylynge see fanle

fayn, adv from adj (OE fægen) gladly, eagerly, 3/29

fayr, fayrnesse see fair

teble, ad] (OF feble) weak, 5/34, 36, as sb $7 / 2$, feble fare insufficient food, $37 / 1$

teblen, inf (from adj OF feble) become weak, $3 / 14$ febre, sb (L februs) fever, $37 / 20$

fed, pp (OE fêdan) fed, 27/9, fedıth, pr $3 \mathrm{sg}, 37 / 6$

feet, sb $\mathrm{pl}$ (OE fōt, $\mathrm{pl}$ fēt) feet, $35 / 6,39 / 4$

ferned see feynen

ferth, sb (AF feld, fe1) farth, 33/11, ferthful, adj (AF feid + ful) faithful, loyal, 25/19, 35/10, ferpfullere, comp , $7 / 27$

felawschepe see felowschep

fele, pr subj 3 sg (OE félan) feel, 23/30

felicite, sb (OF) felicity, happiness, $27 / 32$

telouzschepe see felowschep

felow, sb (ON cf OI fēlagi) companıon, friend, $7 / 27$, felowschep (from felow) company, social intercourse, 35/9. felowschepe, 27/12, felawschepe, 15/14, felouzschep $(e), 29 / 15,27 / 17$

fer, adv adj (OE fēor, feorr) far, $23 / 21,41 / 8$

fere, sb (OE gefēra) companion, $7 / 27$, $35 / 10$

feven, pr $3 \mathrm{pl}$ (OE féran, fǣran) fear, $29 / 2$

ferper, ad] (OE furpor with the vowel of ME ferre(r), comp of fer) further, $39 / 4$

ferpinges, sb pl (OE feorpung) farthings, 27/11

fesaund, sb (OF faisan) pheasant, $27 / 10$

feste, sb (OF feste) feast, 27/11, 39/22

feteres, sb pl (OE feter) shackles, fetters, $25 / 29$

fetered, pp (from sb feter) fettered, shackled, 31/26, feterid, pp $21 / 9$

fetoured see farre fetoured

fewe, num (OE fëawe) few, 5/4, 27/11

feynen, pr pl (OF feindre, pr part feignant) imitate deceptively, 5/1, ferned, pp pretended, $35 / 5$

feyre, ad] see farve

fiche, $1 \mathrm{mp}$ sg (OF fichier) fix, plant furmly, $13 / 24$ 
filynge, pr. part. (OE fỹlan) defiling. disgracing, 23/18.

finde $\bar{p}$ see fynde.

fire, sb. (OE fỹr) fire, 39/37.

first, adj. num. adv. (OE fyrst) first adj., 13/29; adv. 25/23; firste, adj., $27 / 7,31 / 30$.

flater, pr. subj. sg. (OF flater) flatter, 35/18.

flateres, sb. pl. (OF flatere, flateur) flatterers, 35/5.

flawme, sb. (AF flaumbe, flaume) flame, blaze, heat, $37 / 6$.

fle, pr. pl. (OE flēon) fly, 37/8.

fleil, sb. (OE *flegel, LOE fligel) flail, $9 / 9$.

flesch, sb. (OE flēsc) flesh, 7/20, 9/1. fleschli, adj. (OE flǣsclic) carnal, fleshly, 27/4.

flod, sb. (OE flōd) river, water, 41/13.

flouzres, sb. pl. (OF flour) prime, height, 33/21; flowres, 33/note to 1. 21.

flowip, pr. 3 sg. (OE flōwan) flows, $31 / 12$.

folie, sb. (OF folie) foolishness, stupidity, 23/27.

folity, adv. (from OF sb. folie) foolishly, stupidly, 33/29.

folk, sb. (OE folc) folk, 13/14, 31/26. folwe, pr. subj. 3 sg. (OE folgian) follow, $3 / 28$; folwen, inf. 33/31; pr. pl., 33/17.

fond see tynde.

fonstone, sb. (OE font, L fontem + $\mathrm{OE}$ stān) fontstone, 15/2.

fool, sb. (OF fol) fool, 37/8.

for, conj. (OE for) for, because, $3 / 3$, $23 / 36$; so that (final) $3 / 12,9 / 19$; prep. for, because of 9/26, 39/9; for to, prep. to, in order that, 9/31, $37 / 24$.

torbede, pr. subj. 3 sg. (OE forbèodan) prohibit, forbid, 23/8; pp. 41/3; forbede $p$, pr. 3 sg. forbids, $5 / 15$.

foreyn, adj. (OF forain, ML foraneus) out of doors, 23/19. forfendit, pp. (OF defendre \& $\mathrm{OE}$ forbēodan) prohibited, 31/8.

torfeten a zen, pr. pl. (from OF pp. forfet) offend against, $5 / 2$.

forzete, imp. sg. (Angl. forge(o)tan) forget, $25 / 21$; inf., $31 / 2$; for zeten, pp. $7 / 19$; forgetynge, vbl. sb. forgetfulness, oblivion, $25 / 3$.

forme see fro.

formed, PP. (L formāre, OF fourmer) formulated, expressed, 27/27.

fortune, sb. (OF, L Fortūna) fortune, chance, 13/28, 29/7.

for $\bar{p}$, adv. (OE forp) forth, 29/11.

for $p i$, pronominal adv. ( $\mathrm{OE}$ for $\mathrm{py}$ ) therefore, 23/5.

forthing, vbl. sb. (OE geforpian) promoting, assisting, 9/2.

for whi, pronom. adv. (OE for hwi) for what reason, 31/17.

fou $3 l$, adj. (OE fúl) unattractive, ugly, 3/25; fouzle, 3/31; fouzlere, comp., $3 / 30$.

foul, sb. (OE fugol) fowl, 39/24.

found, founden see fynde.

foundere, sb. (AF fundur) founder, originator, 13/11.

townden see fynde.

fowten, pp. (OE feohtan) fought, 7/3. trangeleyn, sb. (AF fraunclein) landlord, 29/3.

fraunchis, sb. (OF fraunchise) freedom, independence, 23/34.

fre, adj. (OE frēo) free, 21/15; fre born, of noble/free birth, 21/16; fredam, sb. (OE frēodōm) freedom, 25/6; free, free, noble, 21/5, 25/9; free entre, free access, 33/26.

freend, sb. (OE frēond) friend, 33/23, 37/15; frende, $7 / 33$; frendes, $\mathrm{pl}$. $35 / 5$; frenchip, sb. (OE frēondscipe) friendship, 13/6; frenschepe, 29/15.

frenetzk, adj. (OF frenetique) irrational, crazy, 11/24.

treynede, pa. sg. (OE gefrægnan) asked, inquired, 9/29. 


\section{GLOSSARY}

fro, prep (OE from, fram, ON frā) from, 9/9, 21, forme, 23/9 (not in OED or MMED) , from, 9/26

frowardnesse, sb (OE fromweard + nesse) obstinacy, arrogance, 23/26, $33 / 17$

from see fro

frute, sb (OF fruit) fruit, 3/28, 15/10

fugure, in fugure, sb (L in figūra) symbolising, $41 / 4$

lul, adj (OE full) replete, full, 37/26, tul of, sated, weary, 35/8, ful adv very, 7/16, 29/5, fully, adv (OE fullice) fully, $9 / 3$

$f y$, inter] (OF fi) fie, 15/25

tyn, adj (OF fin) fine, of superior quality, $5 / 35$, fyne, 27/18

tynde, inf (OE findan) fund, 25/5,

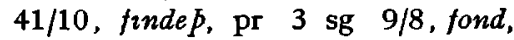
pa $3 \mathrm{sg}, 23 / 26$, found, pa $2 \mathrm{sg}$, $7 / 27$, founden, pP 15/21, fownden, pa pl considered, found, 33/23, fownden of, pp supported, provided with, $29 / 13$

\section{G}

galle, sb (OE galla) gall, 41/7

gamen, sb (OE gamen) amusement, play, 31/18

gardeines, $\mathrm{sb} \mathrm{pl}$ (OF gardın, from Gmc) gardens, 11/16

garnement, sb (OF garnement) artıcle of dress, $5 / 6$

gentul, adj (OF gentil) noble 7/7, 13/11, gentrl folk noblemen, 15/4, gentulmennes, sb gen $\mathrm{pl}$ noblemen's $13 / 22$, gentrlnes noble rank, nobility, $21 / 13$

gest, sb (ON, cf OI gestr) guest, 7/13, $27 / 8$

gilt, adj (pp of $\mathrm{OE}$ (ofer)gyldan) gilt, $27 / 18$

glad, adj (OE glæd) glad, happy, 11/1 , gladder, comp , 35/20

glone, sb (OF gloure, glorie) glory, worldly honour, 13/7

gloriouzs, adj (AF glorious) glonious,
$23 / 17$, glonous, $3 / 20,5 / 13$, glorous, $15 / 9$

glotenye, sb (OF glotonie) gluttony, $27 / 5,39 / 9$

glotoun, sb (OF gloton) glutton, 41/8 go, inf (OE gān) go, 27/18, imp sg , $27 / 12$, pr $1 \mathrm{sg}, 37 / 26$, gost, pr 2 sg, 23/29, 27/26, gon, pr $3 \mathrm{pl}$, $31 / 32,33 / 17$

god, adj see good

god, sb (OE god) god, 5/22, 25, goddes, sb pl gods, 19/6, goddis, gen sg god's, 31/23, goddisbondes, sb pl (OE god + ON band) fetters of god, $9 / 20$

gold, sb (OE gold) gold, 13/30

good, adj cf god (OE gōd) good, 7/29,

$25 / 31$, god, 37/13, good, sb good. 31/27, goodes, sb $\mathrm{pl}, 31 / 24,28$. godes, 29/14, goodnesse, sb. (OE gōdnes) goodness, virtue, excellence, $25 / 25,31 / 29$

gost see go

gostlı, adj (OE gāstlic) spirıtual, 21/10 goten, pp (ON, cf OI geta, o due to analogy of class IV) begotten, engendered, 19/9, 13, gotyn, pp 19/22

gouernaunce, $\mathrm{sb}$ (OF gouvernance) rule, office of ruling, $7 / 1$

gouerne, inf (OF governer) rule (trans E intrans), 23/5, gouerned, $\mathrm{pp}$ ruled, $23 / 5$, gouernen, inf , $13 / 20$

gouernour, sb (OF governeur) ruler, keeper, $25 / 25$

grace, sb (OF grace) favour, credit, $25 / 31$, god's grace, $9 / 25,31 / 23$

gred $\imath$, adj as sb (OE grēdıg, grǣdıg) greedy, gluttonous, 39/11

grees, sb pl (OF gré) flight of stairs, steps, $13 / 25$

gret, adj (OF grēat) great, large, 5/7, 15, grete, great, $11 / 21,37 / 8$, gretly, adv greatly, $9 / 12$

greuest, adj sup (OF grevous) most oppressing, 21/3, greuous, adj heavy, burdensome, 9/6, 35/23, greuou $35,7 / 31,23 / 27$ 
grom, sb. (OE "grōm) servant, 29/4. grounde, sb. (OE grund) ground, 23/22. grucche, inf. (OF groucier, gruchier) grumble, be discontent, 33/29; imp. sg., 9/20; pr. 3 sg., 31/12; grucchest, pr. 2 sg., 41/9; grucching, vbl. sb. resentment, complaining, 5/12, $23 / 28$.

\section{3}

3 at see zeue.

3 ate, sb. (OE gat, geat) gate, 33/25.

$3^{e}$, interj. (OE gē, WS gea) yea, 5/22, $27 / 4$.

3e, pron. (OE ge, gẽ) you pl., 23/6; 30w, pron. pl. obj. (OE low) you, $39 / 16$.

zelden, inf. (OE geldan, gieldan) to present, hand over, $7 / 28$.

zerde, sb. (OE gerd, gierd) rod, staff, $21 / 8$.

$3^{e u e, ~ i n f . ~(O E ~ g e f a n, ~ g i e f a n) ~ g i v e, ~}$ 19/13, 25/30; ziffe, inf., $3 / 6$; zeuen, pp. given, 19/16, 25/7, 29/10; зеие $p$. pr. $3 \mathrm{sg}$. gives, $33 / 12$; 3at, pa. $3 \mathrm{sg}$. gave, $9 / 30$.

3if, conj. (OE gif, gyf) if, 5/2, 5.

ziffe, inf. see zeue.

3ifte, sb. (OE gift) gift, 21/7; 3iftes, pl., 3/8.

$3^{i s,}$ particle (OE gẽse, gise) yes, 27/33. 3it, adv. (OE get, geta, glet) yet, further, $3 / 24,23 / 17$. See also neper. 3 our, pron. (OE èower) your, 23/7.

zow see ze.

\section{$\mathbf{H}$}

had, hadde, etc. see haue.

halt, adv. (OE half, healf) half, 23/29.

halle, sb. (OE hall, heall) palace, court hall, 15/20.

ham see be, vb.

handes, sb. pl. (OE hand) hands, 33/21. handymaidenes, sb. pl. (cf. OE handpegn) handmaidens, 31/31.

happe, pr. subj. sg. (from ON sb. happ) happen (impers.), 13/7, 31/18; happede, pa. sg. should happen, 23/8; happeneth, pr. 3 sg. happens, $7 / 30$.

hard, adj. (OE hard, heard) severe, hardhearted, 25/17; hard fare, bad, insufficient food, 37/14, 16; hard, adv. (OE harde, hearde) hard lokked tight, 25/3; harde, pou farist harde you are ill fed, 41/9; hardnes, sb. hardness, severity, 37/15.

harm, sb. (OE hearm) evil, harm, mischief, 9/13; harmes, pl. evils, $37 / 12$.

harmep, pr. 3 sg. (OE hearmian) harms, injures, 5/18.

hatest, pr. 2 sg. (OE hatian) hate, 37/17. haue, inf. (OE habban) have, 9/33; haue, pr. 1 sg., 7/8; hast, pr. 2 sg., 5/37; hap, pr. 3 sg., 7/7; hath, pr. 3 sg., 7/11; hauen, pr. pl., 21/17; haue, pr. subj. 2 sg., 13/10; haue, pr. subj. 3 sg., 39/21; haddest, pa. 2 sg., 23/14; haddist, pa. 2 sg., 11/14; hadde his askyng, pa. 3 sg., received what he requested, 9/23; hadde, pa. pl., 13/12; hadden, pa. pl., 7/3; had, pp. regarded, esteemed, 3/19. $h e$, pron. (OE hē) he, 23/10; his, 5/23; is, $3 / 23$; him, 25/25; hym, 25/19.

he, pron. see sche.

hed ache, sb. (OE hẻafod + æce) headache, 39/3; cf. heued.

hede, sb. (from vb. OE hëdan) take hede, pay attention, 23/18.

heder too, adv. (OE hider + tõ) hitherto, 29/12; hedur, adv., 31/21. heiere, sb. (OF heir) heir, 19/11; heire, $19 / 19$.

heizest see hize.

hele, sb. (OE hǣlu) bodily health, good fortune, $7 / 29,9 / 22$.

hele, inf. (OE hælan) cure, heal, 9/30; helede, pa. 3 sg., 9/27; helid, pp., $27 / 30$.

helle, sb. gen. sg. (OE hell) of hell, 3/6. helpe, inf. (OE helpan) help, 7/32; helpen, inf., 19/3. 


\section{GLOSSAR Y}

\section{hem see per}

hender, adj comp (OE gehende) nearer, more convenient, 33/12

hepe, imp sg (OE hèapian) load, heap, $25 / 13$

her, sb (OE hēr, hāer) ha1r, 5/1

her see sche

her, poss pron fem sg (OE hiere), $31 / 15$, here, 29/14, her

$h e r$, poss pron pl (OE hiera) their, $27 / 6$, here, 15/5, heren (disjunctive) theirs, $7 / 4$, fer (ON perra, perra), $35 / 6$, pere, $11 / 24$ their

herbored, PP (OE herebeorgian, cf ON herbergja) harboured, lodged, 5/36

herd, Pp (OE hēran, hieran) heard, $9 / 22,25 / 22$

herden, ad] (from $O E$ sb fem pl heordan $=$ hards, hurds, the coarser parts of flax or hemp) made of harden, a coarse fabric, 29/4

here, adv (OE hēr) here, 23/18, 29/10

here see her (their), her (poss her) and sche

hertes, sb pl (OE heorte) hearts, $15 / 24$

heritage, sb (OF heritage) heritage, $15 / 8$, herytage, $19 / 20$

hesi, adj (OF a1sé) easy, 27/8

heued, sb (OE hēafod) head, 9/8, cf hed

heuene, sb (OE heofon) heaven, 19/20, 23/17, heuene, gen $\mathrm{pl}, 23 / 31$

heuenelı, adj (OE heofonlic) celestial, heavenly, 33/8

heuy, ad] (OE hefig) heavy, 25/8, heuy, adv (OE hefige) heavy, 23/29, euyere, adj comp, 35/20

me heuyep, vb impers pr $3 \mathrm{sg}$ (OE hefegian) am bowed down oppressed (impers use not in OED), 9/5

heuynesse, sb (OE hefignes) grief, dejection, 19/24, 41/2

heyzere see hize

hid, pp (OE hȳdan) hidden, 25/7, $h \imath d \imath p$, pr $3 \mathrm{sg}, 31 / 9$ hıep, pr 3 sg (OE hIgıan) hastens, $25 / 15$

hize, adj (OE hēh, hēah) high, 7/29, 11/21, heyzere, comp , 5/31, herzest, $\sup (\mathrm{adj}), 31 / 17$, heizest, sup (adv) 23/16, higze, 13/5, hygnesse, tallnes, height, 5/33, hyze, 15/20, 23/23

him see he

hinderyng, vbl sb (OE hindrian) hınderıng, 9/1, hyndirde, pa sg , $5 / 24$

his see he or hit

hit, pron (OE hit) it, 5/18, 7/17, $\imath t$ $7 / 18,7 / 29$, his its, $5 / 18,13 / 25$

hode, sb (OE höd) hood, 37/7

holde, sb (OE hald \& ON hald) hold, $27 / 25$

holde, inf (OE haldan, healdan) keep. hold, 31/20, holde vp, support, 13/24, holden, 37/8, holdep me lowe, pr $3 \mathrm{sg}$ oppresses me, $7 / 24$

hole, adj (OE hāl) whole, see alle pe hole

holı, adj (OE hālıg) holy, 19/18, 23/16, holy, 5/10, 11/23, holnli, adv , 41/6, holuchirche, Holy Cburch, 11/11, holnnesse, sb (OE hālıgnes) holiness, $9 / 3$

holsom, adj (OE hālsum) wholesome, 39/26

homly, adj (OE hām + ly) simple, plain, 13/14, 39/35

honeste, adj (OF honeste) respectable, $5 / 37$

honeste, sb (OF honeste) moral excellence, high rank, 13/16, 19/26

honour, inf (OF honorer) worship, $19 / 5$, honoure, inf adorn, beautify, $3 / 12$, honoureth, pr $3 \mathrm{sg}$ adorns, confers dignity upon, $3 / 23$

hony, sb (OE hunig) honey, 5/18, 41/3

hoo, interj (OF ho) halt, stop, 33/5

hope, sb (OE hopa) hope, 25/13, $31 / 19$

hornes, sb $\mathrm{pl}$ (OE horn) horns, 5/1

hors, sb. (OE hors) horse, 7/11, 27/18 
hou3s, sb (OE hūs) house, 39/21, houzse, 39/21, hows, 5/15, 27/13

houzsed, PP (OE hūsian) lodged, enclosed, 5/35

houzshold, sb (house + hold) household, 25/26, howsel, 15/21

how, adv (OE hū) how, 3/31, 23/28

howen, pr pl (OE āgan) owe, 31/32

hows see houzs

howsel see houzshold

huches, sb pl (F huche, ML hūtıca) chest, coffer, 27/15

humour, sb (AF humour) inclination, $9 / 10$

hungri, adj (OE hungrig) hungry, $33 / 23$

hungur, sb (OE hungor) hunger. $39 / 18$

hurled, pp (etym uncertain) hurled, tossed, 23/20

hygnesse, sb (OE hēahnes) tallness, height, 5/33

hyze see $h_{3} e$

hym, pron see he and per

hyndirde see hinderyng

\section{I}

I, pron (OE 1c) I, 3/11, 19, me (OE mē) me, $3 / 1,7 / 24$

gdel, adj (OE Idel) 1dle, doing nothing, $35 / 6$

verarches, sb pl (OF verarchie) hierarchies, angelic hosts, 23/32

ghk, adj (OE gelic) same, like, 13/28

2lke, adj (OE Mercian ylc) the

Northern form of eche, each, 27/16

ille, adv (ON 1lla) ill, 27/12

impediment, sb (L impedimentum) hindrance, 5/21

in, prep (OE in) in, 5/32, 9/25, inne, $5 / 21$, jnne, adv in, 15/23

incurable, adj (OF incurable) incurable, 9/35

induellande, pr part (in + $\mathrm{OE}$ dwellan) inhabitants (in lit sense not in OED), 11/22 infames, adj (OF infameux, L infāmıs, -es) of lll repute, 19/27

ınfırmite, sb (F infirmité) bad health, weakness, 9/12, 25

inhabıt, inf (OF enhabiter, L inhab1tāre) dwell in, occupy, 5/15

inhrbete, pr subj 3 sg (ad L inhibitum) prevent, prohibit, 19/17

ınıurye, sb (L injūna) injury, wrong, $29 / 9$

ınned, pp (OE innian) got in, entered, $7 / 12$

ృnow, adj (OE genōh, genōges) enough, $7 / 18,25 / 9$

inportune, adj (F importune) troublesome, vexatious, $39 / 2$

inpossible, adj (F impossible) impossible, 39/37

inpressid, pp (L impress-, pp of imprimere) imprinted, stamped, 41/15

inquisicioun, sb (OF inquisition) investıgation, $35 / 4$

insirument, sb (F instrument) means, $7 / 17$

in to, (OE in tō) prep into, 25/23

inwnt, sb (formed in ME) conscience, reason, $21 / 11$

jogolours, sb pl (OF joglere, jougelour) jesters, tricksters, 35/7

torfullı, adv (OF joie + fullı) joyfully, $33 / 9$

jorze, inf (OF joir) rejolce, enjoy, $35 / 12$

jongkerie, $\mathrm{sb}$ (etym uncertain)

banquet, feast, 35/1

is see be

ıs, gen of pers pron (OE his) his, $3 / 24$

ıssu, sb (OF 1ssu) offspring, 13/10

เt see hit

juel, adv (OE yfele) evil, 17/2, juel, $\operatorname{ad}_{1}, 19 / 4$

juel, sb (AF juel) jewel, 9/18, jueles, $\mathrm{pl}, 9 / 16$

juge, sb (OF juge) judge, $7 / 29$

ıustl, adv (F juste) rightly, properly, $19 / 8$ 


\section{GLOSSARY}

$\mathbf{K}$

kach, Imp sg (ONF cachier) seize, $31 / 18$

kake, sb (ON kaka) loaf of bread, $39 / 20$

kald see calles

kalenge, inf (OF calonger) claim, 13/11

kam see komen

kan see kun

kare, sb (OE caru) sorrow, care, $29 / 5$

katel, sb (ONF catel) property, goods, $29 / 5$

keres, sb pl (OE c⿱亠̄g) keys, 25/5

kepe, inf (OE cẽpan) keep, occupy, $3 / 13,25 / 32$, pr pl observe, keep, $39 / 7$, imp sg watch, 7/29, kepen to, pr $\mathrm{pl}$ obscrve, 31/3, kepip fro, protects against, 27/4, kept guarded, 9/20, kepte, pa sg kept, grazed, $15 / 17$

kisse, inf (OE cyssan) hiss, 39/15, $k i s s i p$, pr $3 \mathrm{sg}, 15 / 3$

knave, sb (OE cnafa) servant, one of low condition, 23/17

knowen, Pp (OE cnāwan) known, 11/11, knowest, pr $2 \mathrm{sg}, 27 / 32$, $31 / 7$, knowe 5 , pr $3 \mathrm{sg}, 27 / 10$

knowlech, $\mathrm{sb}$ (ME, origin of -lech is obscure, OE lǣean from lāc'), knowledge, 13/19

$k n y t, \mathrm{pP}$ (OE cnyttan) tied, knit, 5/7

komen, inf (OE cuman) come, 33/8, pp 13/27, 15/12, come, pp, 13/5, kome $p$, pr $3 \mathrm{sg}$ comes, 15/2, come, pa subj $2 \mathrm{sg}, 19 / 2, k a m$, pa $3 \mathrm{sg}$, $15 / 15,16$, komyng, vbl sb coming, arrival, 27/7, komynge, 13/29, kumme $p$, pr $3 \mathrm{sg}, 39 / 13$

komynly, adv (OF comun + ly) generally, 27/23

kotevelles, $\mathrm{sb} \mathrm{pl}$ (OF coterel) cottagers, low peasants, $13 / 27$

kouer, inf (OF covru) to cover, 39/29 koueres, sb $\mathrm{pl}$ (F covert, $\mathrm{pl}$ covers) covers, $29 / 13$ kouerynge, vbl sb (OF covrir) coverIng, clothing, 29/12

kouzche, sb (F couche) bed, restingplace, $27 / 30$

kowde see kun

kummep see komen

kun, inf (OE cunnan) be able, 27/16, kan, pr $3 \mathrm{sg}, 31 / 20$, kunne, inf $37 / 24$, couden, pa $\mathrm{pl}, 39 / 31$, kowde, pa $3 \mathrm{sg}, 25 / 3$, pa pl, 25/4, kunnynge, vbl sb knowledge, 5/17, $31 / 32$

kuntre see cuntre

kynde, sb (OE gecynde) nature, life, $3 / 6,39 / 6$, be kynde, by nature, naturally, 21/6, kyndeln, ad] (OE gecyndelic) natural, characteristic, 31/13, kyndely, adv naturally, $27 / 32$, kyndly, adj natural, implanted by nature, kyndly wrt, $7 / 12$

kyndom, sb (OE cyningdōm, cynedōm) kıngdom, 35/26

kyng, sb (OE cynıng, cing) kung, 5/22, $15 / 4$, kynges, $\mathrm{pl}, 15 / 18$, kingges, $\mathrm{pl}, 33 / 10$, kyngges, $\mathrm{pl}, 15 / 4$

kynne, sb (OE cynn) family, offspring. $13 / 17,18$

L

laborist, pr 2 sg (OF labourer) toll, labour, 33/7

labour, sb (OF labour) trouble, exertion, $7 / 22$, labourus, $\mathrm{pl}, 23 / 18$

lady, sb (OE hlāfdıze) lady, 25/26

lakkıd, pp (ME lak, cf Du lak and ON lakr) blamed, 19/8

langure, inf (OF langorer) lose health, 9/28

larche, adj (OF large) tall, 5/23

lasse, ad] (OE līssa) less, 7/21, 11/14, lesse, smaller, $11 / 20$

laste, adj (OE latost) last, 31/29, at pe laste, adv finally, at last, 25/28

lawe, sb (ON lagu) law, 19/11, 31/18. lawful, adj legitımate, 13/10, 19/19, lawfull, 23/7, lawfull, adv , 15/8 
lawter, sb (OE hleahtor) laughter, lette, inf (OE lettan) hinder, prevent, $41 / 2$

lawyng, pr part (OE hlæhhan) laughing, 39/17 $35 / 19$, letted hem of her reste gave them no peace, 27/6, lettid, pa sg , $5 / 28$

lecke, sb (OE lēce, lāce) physıcian, 9/33

leccherne, sb (OF lecherie) lust, lechery, $17 / 1$, leccherye, $19 / 22$, lechery, 3/26

lede, pr $1 \mathrm{sg}$ (OE læedan) lead, 25/17

lefe see leue (live)

left see leuep

leful, adj (ME leveful) permissible, $23 / 7$, lefull, adv , $13 / 6$

legale, adj (F légal) legale seruaunt as regards the law, 21/8

len see lenze

lerze, inf (OE lecgan) lay, 15/22, leye to add to, 23/27, len, imp sg, 23/5, ley, $1 \mathrm{mp} \mathrm{sg}, 21 / 4$, levd, $\mathrm{pP}, 9 / 20$. lezde, pa $3 \mathrm{sg}, 15 / 19$, liggeth, pr 3 sg $29 / 4$

lemes, sb pl (OE lim) members, limbs, 3/14

lemman, sb (EME lēofmon) sweetheart, paramour, 3/26

lenage, $\mathrm{sb}(\mathrm{OF} \mathrm{l}(\mathrm{g})$ nage) lineage, ancestry, 13/11

lengere, lengest sec long

lent, pp (OE länan) lent, 5/4, 29/10. pa sg, 29/12

lerne, $1 \mathrm{mp} \mathrm{sg}$, (OE leornian) learn, $5 / 3$, lernen, inf , $33 / 15$

lesse see lasse

lessoun, sb (OF leçon) lecture, 31/28

lest, conj ( $\mathrm{OE}$ py līs pe) lest, for fear that, $3 / 30,37 / 19$

lest, vb inf (OE lystan) like, 27/22, list, pr $2 \mathrm{sg}, 5 / 2$, him liste pleases him, 39/23, liste, inf , 35/7, here lust pleases her, 29/14

lest, adj as sb (OE lǣst) least, 31/29, $33 / 6$

let, 1mp sg (OE lētan, lētan) allow, let, 25/12, lete li3t be, pr pl attach little importance to, $3 / 27$, letist litil by, pr $2 \mathrm{sg}$ have no high opinion of, despise, $39 / 18$

leue, vb inf (Angl leofian, WS libban, lifian) live, 5/3, leuen, inf, $33 / 11$, lifen, inf, 37/24, lefe, imp sg, 19/20, lift, pr $3 \mathrm{sg}, 35 / 21$, leuyng, vbl sb life, livelihood, 19/11, 33/1, leuynge, 19/4, 35/18, lyuyng, 19/26, lyued, PP, 35/22, lyuere, sb liver, one who lives, $19 / 18$

leue, $\mathrm{sb}$ (OE lēaf) taken here leue leave, $33 / 16$

leueve, $\mathrm{adv}$ from adj (OE lēofra) more gladly, $37 / 4$

leue $p$, pr 3 sg (OE læ̈fan) leaves, $31 / 10$, left, pp , 31/1

leye see let

leyth, adj (ON leıpr, cf OE lāp) repulsive, ugly, $3 / 25$

liberte, sb (F liberté) liberty, 25/21

lıcens, sb (F licence) leave, permission, 33/12

licor, sb (OF licour) liquid, 41/14

lit, sb (OE lff) life, 33/20, 35/19, lızt, $9 / 33,23 / 12$

lifen see leue (live)

liflode, sb (OE liflād) food, sustenance, $39 / 31$

lift see leue (live)

lnggeth see lerze

lizt see lif

lizt, adv (OE lēohte) lightly, poorly. $3 / 27$ See also lith-

$l_{3} t$, ad] (OE lēoht, lihht) light, not heavy, 7/32 See also $l$ th -

lızt, sb (OE lēoht, liht) light, 11/9

likerouzs, adj (AF lukerous) of dainty appetite, fastidious, 39/23, likerous, adj pleasing to the palate, 9/27, $39 / 27$, of dainty appetite, 27/19, $41 / 12$

lıkıdde, pa sg (OE IIc1an) liked, 33/11, $l \imath k \imath p$, pr $3 \mathrm{sg}$ impers pleases, 23/33 
liknesse, sb (OE IIcnes) likeness, low, adj (ON lāgr) low, 5/15, lowe, semblance, $5 / 1$

lippes, sb pl (OE lippa) lips, 39/23

list, sb see lust

list $(e)$ see lest $\mathrm{vb}$

litel, adj (OE lytel) small, little, 5/12, lutul, 5/12, 29/5, lutıl, adv, 3/27, 39/18, litnlnes, sb (OE lytelnes) smallness, $5 / 28$

lithlier, adv comp (OE lēohtlicor, lihtlicor) more easily, 11/8, luthly, adv readily, easıly, $37 / 7$, see also $h 3^{t}$

lithsum, adj (ME lightsome) graceful, merry, $7 / 27$

lo, inter] (OE lā) see, behold, 25/6

lode, sb (OE lād) load, burden, 23/27

lok, sb (OE loc) vnder lok under lock, 9/17

loke, sb (from vb) look, appearance, $27 / 6$

loke affter, $1 \mathrm{mp}$ sg (OE löcian) expect, look in hope of getting, 31/16, loken after, $\mathrm{pl}, 31 / 22$, loken $v p$ on, inf look at, 3/32, lokep, pr 3 sg expects, 27/9, lokith, 31/11

loked, pp (from sb loc) locked, 9/21, lokked, PP , 25/3

long, ad) (OE lang) long, 5/13, 30, longe, adv, 29/13, lengere, adv comp (OE lengra), 25/32, lengest. adv sup (OE lengest), 15/10

long of, prep (aphetic form of $\mathrm{OE}$ gelang) due to, $9 / 14$

longep, pr $3 \mathrm{sg}$ (from $\mathrm{OE}$ gelang = at hand, dependent on) belongs to, concerns, $3 / 20$

lord, sb (OE hläford) lord, 5/26, 39/8, lordes, $\mathrm{pl}, 29 / 2$, lordes, gen $\mathrm{sg}$, $21 / 11,25 / 31$

lordenes, sb pl (OE hlāfording) lords, $7 / 15$

lore, sb (OE lār) teachıng, 5/2

los, sb (OE los) loss, 33/28

losede, pa sg (from loose, adj ON lauss) loosened, untied, 25/29

loue, pr $3 \mathrm{pl}$ (OE lufian) love, 27/24. $33 / 19$, loue, subj sg, $27 / 11$

$7 / 24$, lowest, ad] sup , $7 / 14$

lowd, adj (OE hlūd) loud, 31/11

lowly, adj (low + ly) humble, 33/15

lowtede, pa sg (OE lūtan) stooped, obeyed, $23 / 35$

lufly, adj (OE luffic) attractive, beautıful, $3 / 26$

lullth, pr 3 sg (imitative, of $\mathrm{Sw}$ lulla, Du lullen) Julls, 13/29

lust see lest, $\mathrm{vb}$

lust, sb (OE lust) sensual pleasure, $37 / 15$, lustes, $\mathrm{pl}, 27 / 3$, list, 33/10, lusti, adj (ME) pleasant, sensual, $41 / 4$

lyued, lyuere, lyuyng see leue (hve)

M

mad, made see make

magnified, pp (F magnifier) raised to high status, $13 / 16$

mai, marst see may

maiden, sb (OE mægden) virgin, $15 / 21$

maister, sb (OE mægester, L magister) master, 7/22, 25/27, meyster, 37/9

marstries, sb (OF maistrise) feat of skıll, 25/30

make, vb inf (OE macran) make, $23 / 4,37 / 6$, makep, pr $3 \mathrm{sg}, 15 / 4$, mak 2, pr $3 \mathrm{sg}, 9 / 6$, made, pa sg , $3 / 24$, made to, pa sg caused, $7 / 2$, mad, pp , 9/25, made, pp , 11/13

makere, sb (make + er) maker, 21/17 maladıes, sb pl (F maladıe) ıllnesses, 9/27

malice, sb (F malice) wickedness, $21 / 4$

man, sb (OE mann) man, 3/20, 21, mannes, gen $\mathrm{sg}, 15 / 1,19$, men, $\mathrm{pl}$, $7 / 13,14$, mennes, gen $\mathrm{pl}, 13 / 22$

maner, sb (AF manere) kind, 39/6, 18 . manere, 31/28, maneres, $\mathrm{pl}, 19 / 15$ manhod, sb (OE mann + hād) manhood, 5/17

mannes see man 
many, ady (OE manı) many, $7 / 2$, 9/27, manye, $25 / 20,33 / 1$

marchaunt, sb (OF marchand) merchant, 9/19, marchauntes, pl , 29/2

mater, sb (OF matere) ground, subject, $13 / 3$

matrimonye, sb (L mātrımōnıum) matrimony, $17 / 2$

may, aux (OE mæg) may, can, pr $2 \mathrm{sg}$. $11 / 6$, mai, $5 / 21$, marst, $7 / 22,15 / 8$, mayst, 13/11, 31/17, mayt, 19/26, may, pr $\mathrm{pl}$, per may not per of they do not like $1 \mathrm{t}, 37 / 23$, may, pr $3 \mathrm{sg}$, $11 / 6,7$, myght, pa $2 \mathrm{sg}, 41 / 10$, myght, pa $3 \mathrm{sg}, 3 / 7,33 / 31$, myghte, 23/2, 27/20, mygth, 41/12, my $z t, 3 / 7$ me see $I$

mech, adv (OE mycel) much, 35/24, meche, adv , 5/4, sb , 7/21, adj , 5/15 mede, sb (OE mẻd) reward, 33/8 medrcyne, sb (OF medecine) medicine, 9/31, medycin, 39/6

medle, sb (OF medlee) may no medle be mad has nothing to do with, 11/7 meke, adj (ON miukr, EME meoc) piously humble, 41/5, mekenes, sb humility, $19 / 24$, mekenesse, $13 / 3$

men, mennes see man

mene, pr $1 \mathrm{sg}$ (OE mǣnan) mean, $5 / 16$

mene $\bar{p}$ pe (OE mǣnan, Impers) complain, 13/4

mercy, sb (OF merc1) mercy, compassion, 33/22

mener, adj comp (OE myrig) more cheerful, happy, 37/27

merour, sb (OF murour) murror, 7/25, myrrour, 33/32

mes, sb (OF mes) dish of food, mes potage mess of pottage, 39/21

messanger, sb (OF messager) messenger, $5 / 5$

mesurable, adj (F mesurable) moderate, temperate, 39/11

mesure, $\mathrm{sb}$ ( $\mathrm{F}$ mesure) measure, $7 / 11$, $39 / 7$

mete, sb (OE mete) food, 39/18, 27 metıst, pr 2 sg (OE mẽtan) meet, $27 / 16$

meyster see manster

$m i$, pron (OE mln) my, 5/20, 31, my, $3 / 1,9 / 5$, myn, 21/2

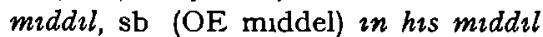
leuynge in the middle of his life, $35 / 18$

mzddis, in middıs of (OE gen middes) in the middle of, $11 / 12$

mightıboned, adj (OE mutıtig + bān + -ed) strongboned, 7/13

misteries, sb pl (AF *misterie, OF mistere) mystery, riddle, 25/6

mo, ad] as sb (OE mā) more, 39/10

mochers, sb pl (EME muchare, from

F) petty thiefs, $27 / 4$

moder, sb (OE mōdor) mother, 15/19. 19/25, modur, 37/5, 41/2

mone, sb (OE mōna) moon, 13/13, $31 / 10$

money, sb (OF monere) money, 35/25, moneye, $39 / 5$

more, adj (OE mära) more, greater, $5 / 14$, adv , $11 / 10$, more ouere, $19 / 13$ morn, sb (OE morgen) at morn in the morning, 37/27

morselles, sb pl (OF morsel) dish, mouthful, 39/30

most (e), adj (OE māst, māst) greatest, $7 / 7,15 / 13$, adv most, $13 / 25$

motes, sb pl (OE mot) specks of dust, spots, blemishes, 19/27

mounteyn, sb (OF montaigne) mountain, 23/16

mowtes, sb pl (OE moppe, mohpe) moths, 33/16

mowth, sb (OE mūp) mouth, 39/2

mulori, sb (OF mulere) vnborn in mulor not born in legitimate wedlock, 19/15, not in this use in OED

mutacions, sb pl (F mutacion) changes, $31 / 12$

myght, etc see may

myghtes, sb pl (OE miht) powers, $23 / 31$ 
$m y(n)$ see $m$

mynde, sb (OE gemynd) mind, 41/10, have mynde, bear in mind, 27/24

mynstrelle, sb (OF ministral) minstrel, $25 / 13$

myraculusly, adv (F miraculeux) muraculously, 9/28

myrpe, sb (OE myrgb) joy, $41 / 2$

myse, sb pl (OE mȳs) mice, 33/16

\section{$\mathbf{N}$}

naked, adj (OE nacod) naked, 21/12, 27/23, nakıd, 15/5,31/10

name, sb (OE nama) name, title, 11/9, $13 / 11$

narwe, adj (OE nearu) narrow, small, 31/11, narwnes, sb (OE nearones) smallness, $11 / 17$

natıunte, sb (OF nativité) burth, 13/2, $15 / 23$

naturel, adj (OF naturel) natural, by nature, 21/6, 31/13

nature, sb (F) nature, 3/1, 3

$n e$, conj (OE ne, n1) nor, 3/7, 7/10

necessarıe, adj (L necessāri-) necessary, 33/1, 39/31

nede, sb (OE nēd) need, want, 33/4, 39/11

nede, inf (OE nèodian) nced, 39/3, nedest, pr 2 sg need, 37/27, nedi $p$ pr $3 \mathrm{sg}$ (1mpers) it is necessary, $15 / 13$, nedith, pr $3 \mathrm{sg}$ needs, 9/7

negardes, sb pl (nig- poss of Scand or, cf ON hnoggr, corr to $\mathrm{Du}$ nauw, + suffix -ard) misers, niggards, $3 / 8$

nekke, sb (ON hnakkı, OE hnecca) neck, 23/25

nev, adv comp (OE, nēr, nēar, ON nār) nearer, closer, 31/23

nest, sb (OE nest) nest, 15/12

nestele, pr pl (OE nestlian) nestle, $3 / 9$

neper, adv con] (OE ne + æeghwaper) neither, 9/23, 11/21, nepur nepur, 11/17, nepur 3tt, used for emphasis, 9/10, nepur, pron neither, 31/20, nepur nopur, adv neither, $27 / 10$

neuer(e), adv (OE næfre) never, $3 / 24,25 / 10$, neuer(e) pe lesse by no means less, $11 / 5,19 / 25$, neuer so (in conditional clauses, denoting an unlimited degree), 35/23, neuerpeles nevertheless, $15 / 14$

next, adv (OE nēhst, nlehst) nearest, $7 / 15$

neyzebour, sb (OE nēh-, nẻahgebūr) neighbour, 27/14

no, pron (OE nān) no $3 / 21,22$, non, $7 / 18,27$, none, $27 / 12$

nobeley. sb (OF noble1e) nobility of rank, noble estate, 11/24, nobleye. $13 / 21$

nobılnte, sb (F nobilité) nobılity, 11/7, 21

noble, adj (F noble) noble, 13/12, $35 / 3$

norzede, pa sg (aphetic form of $\mathrm{OF}$ anoye, cf also OF noire), caused harm, $19 / 5$

nolde, pa sg (ne + wolde) did not want, $25 / 27$

non, none see no

nor, conj (contr of nother) nor, 11/19. 21

norisched, pp (OF nons-, stem of norir) nounshed, supported, 7/6, norschede, pa sg, 29/12

not, adv (OE nōwiht, nāwiht) not, $3 / 1,3$, nouzt, adv not, $5 / 16$, nowt, adv not, 19/10

noping, pron (OE nān + ping) nothing, 3/20, 21, no ping, adv not at all, 27/9

noper see oper

nopur, conj (OE nāhwæper) neither, 23/20 See also neper

nouelte, sb (OF novelté) novelty, $13 / 21$

nouzt see not

nouzt, pron (OE nōwiht, nāwiht) nothing, $31 / 30$ 
now, adv. (OE nū) now, $35 / 4 ;$ now... now..., 31/11.

nowt see not.

nyghtes, on, (orig. adv. gen. -es, analogically added to $\mathrm{OE}$ fem. sb., niht) by night, 31/9; nyzt, 37/6; nyghtis, gen. sg., 29/4.

$n y l$ in wil...nyl... (ne + OE wilt) whether he likes it or not, 25/15.

nyse, adj. (OF nice) foolish, stupid, $35 / 12$.

\section{$\mathrm{O}$}

$o$, interj. oh, 39/10, 41/7.

$o b$, prep. (OE of, ME o, of; assimilated to foll. b) of, $23 / 24$.

obediense, $\mathrm{sb}$. (F obédience) obedience, $23 / 10$

obedient, adj. (F obédient) obedient, $25 / 24$.

obstacle, sb. (OF obstacle) impediment, $19 / 18$

occasioun, sb. (L occasiōnem) ground, circumstance, occasion, 19/24; 37/12; ocasion, $3 / 8$.

odiouzs, adj. (AF odious) hateful, repulsive, $13 / 3$; odious, 39/24.

odour, sb. (AF odour) smell, odour, $13 / 19,39 / 1$.

of, prep. (OE of) of, 3/1, 17; cf. ob; taken of peues by 23/24; come of from, 19/3.

ofer flowed, pp. (OE oferflōwan) inundated, overflowed, 9/14.

offendit, pp. (OF offendre) trespassed, sinned, $31 / 5$.

offered, pp. (OE offrian) sacrificed, $41 / 4$.

offryng, vbl. sb. (OE offrung) sacrifice, $41 / 7$.

ofte, adv. (OE oft) often, 3/5, 31/22; often, $25 / 22$; often tymes, 11/16; ofte sithes, (OE on oftsipas) oftentimes, 9/26.

old, adj. (OE ald, eald) old, 29/15; olde, 29/6, 31/1. olifaunt, sb. (OF olifant) elephant, $7 / 11$.

on, prep. (OE on) on, 23/21, 23; onne, $31 / 3$; on sundur, adv. (OE on sundran) apart, separate, 39/16.

on, adj. num. (OE ān) one, 5/25; all (e) one alone, 11/23, 31/8; be per one, alone, 33/16; ones, adv. (ME) once, $21 / 17,35 / 7$.

oni, ony see any.

only, adv. (OE ānlic), 31/36; al(le) only only, $35 / 12,41 / 15$.

open, adj. (OE open) open, 33/22; patent, evident, 13/28.

opened, pp. (OE openian) disclosed, 9/4; openyd, pp., 3/8; opin, inf., $33 / 29$.

opinions, sb. pl. (F opinion) rumours (a Latinism), 29/1; opinioun, opinion, 31/25; opynyoun, judgment, $37 / 9$.

oppressed. pp. (OF oppresser) ravished, violated, 3/26; oppressid, pp. weighed down, 27/2; oppressing, vbl. sb. oppressing, 27/3.

$o r$, conj. (reduced form of obs. other) or, $3 / 24,7 / 11$.

ordeined, pp. (OF ordein- $3 \mathrm{sg}$. of ordener) ordained, destined, 7/18; ordeynede, appointed, 25/25.

ordere, sb. (OF ordre) order, social status, $7 / 14$; holy orderes, holy orders, $19 / 17$.

oper, adj. (OE ōper) other, 39/28, 33; opere, 31/12, 39/2; opur, 7/10, 31/16; a noper, 31/28; pe topere (OE pæt oper) the other, $9 / 2$.

opes, sb. pl. (OE āp) oaths, swearwords, $37 / 8$.

ouer, adv. (OE ofer) too, excessively, $33 / 29$.

ouer rennep, pr. 3 sg. (over $+\mathrm{OE}$ rinnan, ON renna) runs faster than, $27 / 23$.

ouzr, pron. (OE ùre) our, 11/19; our, 15/19, 41/14; oure, 15/23, 24. 
ouzt, pron (OE āwaht, ōwht) anything, 31/2, owt, $23 / 9$

ou 3 (e) of, prep (OE ūt) out of, 25/12, $17 / 2$, out of, $25 / 15$

owne, adj (OE àgen, āgen) own, 3/17, $29 / 13$

owt see ou $3^{t}$

\section{P}

pacience, sb (OF patience) patience, 7/32, 33/26, pacrens, 33/19

pacrent, adj (OF pacient) endurant of suffering, $33 / 31$

pacient, sb (OF pacient) patient, 9/26 parzede, pa sg (F payer) paid, 9/19 palsie, sb, (OF paralısie) palsy, paralysis, $9 / 28$

panter, sb (OF panter) snare, trap, $31 / 26$

part, sb (OF part) part, 15/13

part, inf (F partur) part from his felawschepe part company, 35/21, partip felowschep disrupts our friendship, 35/2

partrk, sb (OF perdriz, pertriz) partridge (see Phonology, §38), 27/9

passen bi, pr pl (F passer) pass by, 35/6, passen, inf die, 35/17, passith, pr $3 \mathrm{sg}$ passes, is regarded, $37 / 9$

passioun, sb (F passion) passion, suffering, $41 / 8$

path, sb (OE pæp) path, 13/25, 33/12

pechzr prouzd, adj (OF pichier + OE prūd) pot-valiant (not in OED), $37 / 7$

pees, sb (OF pals) peace, 37/8

peniale, sb (OE pening + (e)alu) penny ale, thin ale, 39/24

peramour, sb (OF par amour), lover, $33 / 9$

perauenture, adv (OF per aventure) perhaps, 5/37

perceyued, pp (OF percelvre) apprehended, discovered, 13/23

perchance, adv (AF par chaunce) perhaps, 25/19, perchaunce, 7/9. $23 / 3$ perched, pP (OF periss-, stem of perir) perished, 39/9

perelles, sb pl (F péril) perıls, dangers, $7 / 28,29 / 2$

perfeccioun, sb (OF perfeccion) perfection, $37 / 24$

perfitly, adv (OF parfit + ly) perfectly, 9/25

perpetuel, adj (F perpétuel) enduring, lasting, $7 / 6$

perse, inf (OF percer) pierce, penetrate, 23/30

in pis perti, sb (F partie) in this respect, $19 / 12$

peynte, 1mp sg (OF peint-, pp of peindre) paint, $3 / 16$, peynten, pr $\mathrm{pl}, 3 / 31$

philosophie, sb (OF filosofie) phllosophy, 27/20

philosophore, sb (OF philosophe + our) philosopher, 23/36, philosophur, $15 / 14$

phisician, sb (OF fisicien) physician, 9/26, phisicion, 39/25, phisisian, $39 / 4$

pilgrimes, sb pl (OF pelegrin) pilgrums, 27/22

place, sb (OF place) place, dwelling, $11 / 22,23$

plastere, sb (OE plastre) plaster, 9/15

pleyne, inf (refl) OF plaign-, stem of plaindre) complain, 23/29, 27/26, pleynede, (refl) pa 2 sg, 7/33, pleynes, pr $2 \mathrm{sg}, 5 / 3$, pleynynges, vbl sb pl complaints, $31 / 4$

plesen, inf (OF plesir) please, 39/19, plesid, Pp 29/13

pleyen, pr pl (OE plegıan) play, $31 / 20$

pleynt, sb (OF plainte) complaint, $27 / 27$

podagre, sb (OF podagre) gout, 39/3

ponysch, pr 3 sg (F puniss- from punir) punishes, 19/14

poole, sb (OE pōl) pool, 3/5

pore, adj (OF povre) poor, 35/15, 16 , porer(e), comp, 27/21, 35/17 


\section{GLOSSARY}

possessioun, sb (OF possession) possession, 19/19

mes potage, sb (cf mes $+\mathrm{F}$ potage) mess of pottage, 39/21

pouert, sb (OF poverte) poverty, $35 / 2,9$, pouerte, $27 / 2,13$

powder box, sb (OF poudre + $\mathrm{OE}$ box) spice-box, 39/32

power, sb (AF, OF poer) power, 21/12 poynt, sb (OF point) in no poynt, in no respect (this sense not in $O E D)$. $5 / 29$

preching, vbl sb (OF precher) preachIng, $23 / 6$

precious, adj (OF precios) of great value, $9 / 18$

prenzede for, pa sg (OF preier) prayed for, 9/23, prey, imper sg, 7/32, prey after, pr 1 sg pray for, 9/22 preizere, sb (OF preiere) prayer, 9/30 preised, pp (OF preisier) praised, 3/16, preisid, PP, 19/8, preisinge, vbl sb praise, 13/9, prersynge, $19 / 6$

prerudice, sb (F prejudice) detrıment, damage, $19 / 2$

presens, sb (OF presence) presence, $35 / 12$

presoneres, sb pl (F prisoner) prisoners, $7 / 5,39 / 16$

presoun, sb (OF prisun) prison, 11/1 preuyded, pp (L praevidẽre) arranged, provided, 5/26

pride, sb (OE prȳde, OF prūd) pride, $11 / 24,15 / 25$, pride hem of, pr pl (from sb) pride themselves on, $11 / 23$

princes, sb pl (F prince) princes, 7/2, 13/9, prinse, 25/30

priue, inf (F priver) deprive, 23/33

proceden, pr pl (F procéder) issue, come forth, $13 / 5$

profer, pr subj $3 \mathrm{sg}$ or pl (OF proffrir) tender, present, 13/6

professioun, sb (F profession) profession, $25 / 1$

profetid see profiten pro/ızt, sb (OF profit) profit, advantage, $3 / 4$

profitable, adj (F profitable) fruitful, remunerative, 39/11

profiten, pr pl (F profiter) prosper, gain, 13/22, profetzd, pa sg, 19/3

progentoures, sb pl (F progenteur) ancestors, $13 / 8$

progeny, sb (F progenie) stock, family, $15 / 24$

proper(e) adj (F propre) belonging to oneself, inherent, 19/6, 31/15, properli, adv essentially, properly, 31/34

prophit, sb (F prophète) prophet, $15 / 18$

prouerbe, sb (F proverbe) proverb, concise sentence, 25/21

prouep, pr 3 sg (OF prover) proves, $9 / 18$

prouzd, prouzde, adj (OE prūd, OF prūd) proud, 15/24, 37/7

prudence, sb (F prudence) prudence, $7 / 1$

prudent, adj (F prudent) prudent, 9/25

pulpit, sb (L pulpitum) pulpit, 33/27 purcheth, pr $3 \mathrm{sg}$ (OF purgier) purges, 9/10

\section{Q}

quantıte, sb (OF quantıté) quantity, $5 / 17$

quenchen, inf (OE *cwencan, cf ācwencan) kill, destroy, 3/14

R

rad, $\mathrm{pP}$ see rede

raft, pp (OE rēafıan) deprıved, robbed, $29 / 15$

ragges, sb $\mathrm{pl}$ (ME) rags, 13/30

raunsum, sb (OF raunsom) ransom, 9/19

rauyched, PP (F raviss-, lengthened stem of ravir) carried away, transported, $9 / 15$ 
rebel, adj. (F rebelle) rebellious, refractory, 7/20.

rebukip, pr. 3 sg. (AF rebuker) reproves, chides, $9 / 8$.

receyue, inf. (ONF receivre) accept, $39 / 17$.

recorden of, pr. pl. (OF recorder) bear witness to, $5 / 19$; recordep records, relates, $23 / 36$.

recoueve, pr. pl. (OF recoverer) regain their former position, 31/22.

rede, pa. sg. (OE rèdan, rādan) read, 21/17; reden, pr. pl., 37/20, 41/3; redeth, pr. 3 sg., 31/28; rad, pp. $37 / 19$.

redempcion, sb. (F rédemption) deliverance, redemption, 9/18.

redines, $\mathrm{sb}$. (OE ræ̈d $+\mathrm{i}+$ nes) wisdom (less likely from $\mathrm{OE}$ (ge)ræde + nes, readiness), 7/1.

refreined, $\mathrm{pp}$. (OF refrener) restrained, checked, $9 / 7$; refreyning, vbl. sb., $27 / 3$.

region, sb. (AF regiun) country, 11/11. regne, inf. (OF regner) rule, 15/18, 23/16; reyznede, pa. sg., 5/28.

vehersid, Pp. (OF rehercer) read aloud, $33 / 27$.

rekening, vbl. sb. (OE gerecenian) account, $7 / 28$.

remes, sb. pl. (OF reaume) kingdoms, $13 / 20$.

remocion, sb. (F remotion) removal, taking away, 9/24.

remouyth, pr. 3 sg. (OF remov-, stem of remouvoir) removes, $37 / 12$.

repe, inf. (OE, Angl. *repan) reap, gain, $13 / 9$.

reproued, PP. (OF reprover) censured, condemned, $19 / 4$.

reputacion, sb. (F réputation) esteem, credit, reputation, $11 / 4,15 / 9$.

reved, pp. (OE rǣran) bring to higher position, $7 / 1$.

resoun, $\mathrm{sb}$. (OF raison, reson) reason, understanding, $3 / 3,11$.

reste, sb. (OE ræst, rest) repose, rest,
$27 / 6$; restful, adj. (from sb.) restful, $27 / 30$.

restip, pr. 3 sg. (OE ræstan) rests, $23 / 22$.

reverence, $\mathrm{sb}$. (OF reverence) the condition of being held in esteem, 23/3.

reuevently, adv. (OF reverent $+\mathrm{ly}$ ) with reverence, 19/14.

reward, sb. (ONF reward) reward, $33 / 7$.

reygnede see regne.

rial, adj. (OF rial) befitting a king, magnificent, 11/20.

rich(e) adj. (OE rIce) wealthy, powerful, $33 / 14,20$.

richees, sb. (OF richesse, richeise) riches, wealth, 29/10; riches, 29/7; vichesse, $31 / 31$; richesses, $11 / 22$.

right, rizt, sb. (OE riht) right, 31/8, $3 / 18$; be rizt, rightfully, $13 / 12$.

rise, inf. (OE risan) get up, 39/1; risen, pr. pl., 29/1; risith, pr. 3 sg., 37/7.

robbe, inf. (OF robber) deprive, rob, $5 / 5$.

robere, sb. (AN robere) robber, 27/17.

robes, sb. $\mathrm{pl}$. (OF robe) loose outer garments, $39 / 31$.

rongle, inf. (from ON sb. hrukka (crease) + le, cf. OED runkle, vb.) wrinkle, $3 / 13$.

rose, sb. (OE rose, OF rose) rose, 19/25. rote, roten, adj. (ON rotinn) rotten, $3 / 7,5 / 35$.

rotes, sb. pl. (ON \& LOE rōt) roots, $13 / 5$.

rude, adj. (OF rude) uncultured, unrefined, 13/14, 15.

rule, sb. (OF rule) rule, regulation, $39 / 8$.

rule, vb. (OF ruler) conduct, behave, 25/22.

ruynouzs, adj. (F ruineux, -se) decayed, $11 / 1$.

ryze, sb. (OF ryge, ON rugr) rye, $39 / 20$. 


\section{GLOSSARY}

\section{$\mathrm{S}$}

sacrement, sb (F sacrement) sacrament, $19 / 14$

sacrifice, $\mathrm{sb}$ (F sacrifice) sacrifice, $41 / 3$

sad, adj (OE sæd) constant, 35/11

saf, adj (F sauf) safe, secure, 9/17, safly, adv , 23/22

sagis, sb pl (OF sage) wise men, $25 / 4$

salt, sb (OE salt, sealt) salt, 39/33, adj, 9/14

same, adj (ON same) same, 25/30, $37 / 20$

sat see sitten

sauerly, adv (OF savour + ly) with relish, 29/5

sauery, adj (OF savouré) appetızıng, $41 / 11$

sauiour, sb (OF sauveour) saviour, $41 / 15$, sauyour, $11 / 19,15 / 19$

sauoveth, pr 3 sg (OF savorer, savourer) tastes, smells, 39/25

sauour, sb (OF savour) taste, 33/24

sause, sb (F sauce) sauce, 39/33, 41/10 saw see se

sawe, sb (OE sagu) sayng, proverb, $29 / 6$

sawser, sb (OF saussier) dish, plate, $39 / 32$

schat, sb (OE cæf, ceaf) chaff, 9/9

schal, aux pr $3 \mathrm{sg}$ (OE sceal) shall, will, must, 3/13, schalt, pr $2 \mathrm{sg}$, 39/3, schal, pl, 3/14, schul, pl, $33 / 30,35 / 6$, scholde, pa sg, 27/21, schulde, pa sg, 19/3, schulde, pa pl, 39/5, schuldest, pa $2 \mathrm{sg}, 3 / 15$, schuldıst, pa 2 sg, 27/30

schap, sb (OE gesceap) outward appearance, looks, 3/2, 5/3, shap $3 / 21$

schaply. adj (OE gesceaplíce) beaut1ful, well-formed, $3 / 15$

sche, pron (OE sēo, hēo, spec dev) she, 11/11, 12, he, 29/9, here, 3/26, $9 / 30$ schep, sb pl (OE scèp, sc̄̄p, scēap), sheep, 15/17, schepe, $\mathrm{pI}, 33 / 25$

schepe, sb (OIE scäp, scēap) sheath, $5 / 35$

schewe, inf (OE scēawian) examine, explain, 25/5, schewede, pp shown, $7 / 12$, schewede, pa sg showed, $41 / 13$, schewet, pr $3 \mathrm{sg}, 3 / 32$, scheweth, 13/28, schewe $p, 35 / 20$

scholde see schal

schort, adj (OE sceort) short, 5/14, 16, schortere, ad] comp , 25/18, schortly, adv (OE sceortlice) bricfly, 39/4 schul, schuldest, schuldist see schal schuldres, sb pl (OE sculdor) shoulders $21 / 4$

sciens, $\mathrm{sb}$ (F science) knowledge, learning, $11 / 18$

scole, sb (OE scōl) school, 39/28

scorn, sb (OF escorn) contempt, 35/13 scourgyng, vbl sb (OF escorgier) flogging, whipping, $9 / 9$

se, inf (OE sẽon) see, 37/11, see, $7 / 25$, seen, $\mathrm{pp}, 25 / 4$, sene, $\mathrm{pp}, 11 / 9$, saw, pa $3 \mathrm{sg}, 25 / 2$

seche, adj (OE swylc, swilc, swelc) such, 37/23, 39/17, sıch, 15/6, 33/32, siche, $21 / 7$, such, $31 / 35$

secounde, adj ( $\mathrm{F}$ second) second, $23 / 5$

see, sb (OE s⿱亠凶) ) sea, 31/11, see banges, sea shores, $9 / 14$

seende, $\mathrm{pr}$ subj 2 sg (OE sendan) send, 39/20, sent affter, pp sent for, $23 / 20$, sende, inf , 5/5, 23/32, sendith, pr $3 \mathrm{sg}, 41 / 6$

serd, serze, serth see seye

seke, adj (OE sēoc) sick, 27/29, sik, $7 / 26,9 / 30$

seken, inf (OE sēcan) seek, 15/17

sekenes, sb (OE sēocnesse) sickness, disease, 9/5, seknes, 33/28, 35/23, seknesse, 7/3, 24, siknes, 7/23, 9/24, siknesse, 7/31, 9/35

sekur, adj (OE sicor, L sēcūrus) safe, $23 / 15,27 / 31$, sekerer, comp, 23/5, sekerly, adv, 27/18, sekirli, 13/26, 


\section{GLOSSARY}

sekırnes, sb (OE sicor + nes) safety. $27 / 33$

sekurite, sb (L sēcūritās), 33/18

selden, adv (OE seldan, seldum) seldom, 3/9, 37/26

self wille, $\mathrm{sb}$ (OE selfwill) one's own will, self-will, 21/9

self, adj (in comb with pron $\mathrm{OF}$ self, silf) self, pi silf, 13/15, pi self, $3 / 12$, him self, $33 / 28$, hem self $3 / 31$, pi silff, 13/10

sell, ad] (OE gesēlıg, gesǣlig) blessed, $33 / 31$

semblaunt, sb (F semblant) outward appearance, $5 / 26$, semelaunde, $7 / 12$

seme, pr sub] 3 sg impers (OV scema, ME sēme) seem, 27/7, semed, pp, 11/14, semep, pr $3 \mathrm{sg}$, $31 / 7$

semelaunde, sb see semblaunt

semely, adj (ON sœmlligr) handsome, $3 / 18$, semelynesse, sb pleasing appearance, $3 / 23$

sende, inf see seende

sent aftter, $\mathrm{pp}$ sce seende

sene, pp sec se

seruaund, sb (F servant) servant, slave, $21 / 6$, seruaundes, $\mathrm{pl}, 21 / 6$, seruaunt, $15 / 15,21 / 8$, seruaunt, see also bela, seruauntes, $\mathrm{pl}, 15 / 15$

serue, Inf, (OF servir) 7/17, 23/16, Imp, 21/15, serve, be a servant, seruep, pr $3 \mathrm{sg}, 23 / 15$

seruzce, $\mathrm{sb}$ (OF service) condition of being a servant, service, 23/15, $31 / 33$, seruise, $25 / 19,20$, seruyse, $23 / 28$

sessiounes, sb pl (F session) conferences, assemblies, $23 / 20$

set, imp sg (OE settan) place, set, $33 / 20$

sete, $\mathrm{sb}$ (ON sǣtı) seat, 23/22

seuene, num (OE seofon) seven, 5/8 seuer, inf (OF sevrer) distinguish, $33 / 6$

seye, inf (OE secgan) say, 37/10, serd, pp , 9/24, 33/32, serze, pr pl, 31/27, senth, pr $3 \mathrm{sg}, 15 / 14$, seyze, inf, $39 / 4$, seyzeth, pr $3 \mathrm{sg}, 33 / 4$, seyzt, pr $3 \mathrm{sg}, 39 / 37$

seynt, adj, sb (OF saint) saint, 23/6, seynte, 19/5, seyntes, $\mathrm{pl}, 3 / 27,19 / 3$ shap, sb sec schap sheits, sb pl (OE scēte) sheets, 29/5 sibreden, sb (OE sibrēden, sibrǣen) kinship, $15 / 6$

sich see seche

side, sb (OE sidde) on pat opur side on the other hand, $33 / 18$

$s \imath 3 t, \mathrm{sb}$ (OE sihp, gesiht) sight, 25/31 $s \imath k, 1 \mathrm{mp}$ sg (OE sican) sigh, 15/5

$s i k$, etc, see seke, sekenes

silens, sb (OF silence) silence, 31/3

silf, silff see self

simple, adj (OF simple) simple, 13/2, $15 / 21$, symple, 23/22, 33/19

synnede, pa sg (OE syngran) sinned, $9 / 12$, see synne, sb

sithe, sb pl (OE gen pl sipa) tımes, $5 / 8$

sithen, conj (OE sippan) since, $7 / 20$, adv afterwards, 25/23, sythen, con] , 27/21, sipthen, con] . 23/29

sitten with, inf (OE sittan) sit with, be familiar with, 7/2, sitte, pr $\mathrm{pl}$, 13/23, inf, 31/17, sitip, pr 3 sg, $23 / 21$, sat, pa sg , $23 / 23$

six, num (OF s1x) six, 5/29

skarlet, adj sb (OF escarlate) scarlet, $39 / 31$

skele, sb (ON sk1l) reason, ground, $41 / 1$

skirt, sb (ON skyrta) skurt, lower part of gown, 31/19

slawet, sb (EME slāwpe from OE slāw, adj) indolence, sluggishness, $37 / 6$, slau $3 \not e, 27 / 5$

slawter, sb (ON *slahtr) slaughter, killing, 33/28

slayn, pp (OE slean) defeated, kılled, $25 / 28$, sleeth, pr $3 \mathrm{sg}, 39 / 10$

sleknyth, pr $3 \mathrm{sg}$ (The Northern form repr OE sleccan + -en) extmguishes, $3 / 6$ 
slepe, inf (OE slēpan, slēpan) sleep, $37 / 6$, sleputh, pr 3 sg, 29/5, slepynge, pr part , 25/2

smale, ad] (OE smæl) small, 11/18 smel, sb (EME smel) smell, 19/25

smellynge, pr part (EME smellynge) smelling, 41/7

so, adv (OE swā) so, 3/21, 5/3

sober, ad] (OF sobre) temperate, sedate, 9/6, soburnesse, sb (ME) moderation, $33 / 18,37 / 3$

socour, sb (OF sucurs, soccours) help, assistance, $31 / 23$

sodeyn, ad] (AF sodein) sudden, 33/27 soft, ad] (OE sōft) soft, 27/29, softnes, sb (OE sōftnysse) luxury, voluptuous living, 37/15

sotten, inf (from adj + -en) mollify, $25 / 18$

sogetes, adj (OF suget) subject, obedient, $23 / 6$, sugget, $21 / 3$

sold, pp (OE sellan) sold, 25/23

solempne, adj (OF solempne) grand, imposing, sumptuous, $27 / 31$

son, sb (OE sunu) son, $15 / 6$, sone, $15 / 20,19 / 16$, sones, $\mathrm{pl}, 5 / 25,13 / 20$, sones, gen $\mathrm{sg}, 9 / 8$

sone, adv (OE sōna) soon, 11/9, 31/2, sunner, adv comp sooner, 39/27. sunnere, $11 / 2$

sonne, sb (OE sunne) sun, 5/8, 31/9, sunne, $13 / 13$

sors, sb (OF sors) source, orig1n, 13/18 sorwe, sb (OE sorh, sorge) grief, affliction, $25 / 13,14$

sorwe for, inf (OE sorgian) mourn for, $39 / 36$

soth, adj (OE sōp) true, 29/6

soueveyne, adj $\mathrm{sb}$ (OF soverain, souverein) excellent, 9/33, master, $25 / 24$, souereynes, sb pl lords, $23 / 7$

souzl, sb (OE sāwol) soul, 23/30, souzle, 3/9, 23

souzpe, inf (OE sūpan) eat, sup, 37/22, soupe, 39/24

speche, sb (OE spēc, spǣc) speech, words, $27 / 20$ spedi, adj (OE spēdıg) speedy, swıft, 5/14, speedful, adj (OE spèd + ful) expedient, profitable, 9/32

spekep, pr $3 \mathrm{sg}$ (OE sp(r)ecan) speaks, 27/12, speketh, 39/30

spirizt, sb (AF spirit) spirit, 11/1, 41/5, spirtt, 7/20, 9/1, spiryzt, $35 / 25$

sporle, inf (OF espolluer) deprive, despoil, 21/13, sporled, pp, 31/24, sporlip, pr $3 \mathrm{sg}, 3 / 18$

spore, $\mathrm{sb}$ (OE spora) spur, gilt spore, the 'gilt spur' as the distinctive mark of the knight, 27/18

springen $v p$, pr pl (OE springan) grow, 11/16

staf, sb (OE staf) stıck, staff, 27/17

starith, pr 3 sg (OE starian) shines, $31 / 10$

stature, sb (OF stature) buld, boduly form, 5/20, 27

statutes, sb $\mathrm{pl}$ (OF estatut) laws, decrees, $19 / 18$

in stede of, prep (OE stede, cf OF au lieu de) in stead of, 15/20

steerne, ad] (OE styrne) severe, harsh, $25 / 17$, sterne, $27 / 7$

steppes, sb pl (OE stæpe, stepe) steps, $33 / 31$

stille, adv (OE stille) still, without change, 31/21, stille, adj still, $31 / 11$

stıkkes, sb pl (OE sticca) sticks used as firewood, $37 / 5$

stodre, $\mathrm{sb}$ (OF estudie) his heuy stodre his mental perplexity, 25/8, studie study, 7/1, of pyn owne studie, accomplished by yourself, 3/17

stok, sb (OE stoc) stock, lneage, 13/2

stomak, sb (OF estomac, stomaque) stomach, 39/1

stond, $\mathrm{pr} \quad 3$ sub] (OE standan) stand(s), 35/5, stondep in, consists 1n, $11 / 21$

stoppit, pp (OE stoppian) stopped, $37 / 4$

stor, sb (OE estor) stor of houzse, 
household provisions, whatever happens to be served, 39/21

stone, sb (AF estorie) history, 11/10, storye, 11/22, stories, $\mathrm{pl}, 37 / 23$

straunge, adj (OF estrange) strange, unfamiliar, 27/16

straunger, $\mathrm{sb}$ (OF estrangier) stranger, $27 / 24$

streng $p e, \mathrm{sb}$ (OE strengpu) strength, $7 / 5,8$

strife, 1mp sg (OF estnver) struggle, $3 / 30$

streyt, adj (OF cstreit) narrow, 11/16 strokes, pr $3 \mathrm{sg}$ (OE strācıan) strokes, $9 / 8$

strong, ad] (OE strong) strong, $7 / 3$, stronge, $7 / 9$, sironge, adv , 9/17

studve see stodve

studıe, $1 \mathrm{mp}$ sg (OF estudier) try, apply yourself to, $15 / 9$, studien, pr pl study, read, 37/23

such see seche

sufferaunce, $\mathrm{sb}$ (OF suffrance) patient endurance, forbearance, 33/32

sufficen, pr pl (OF suffiss-, pr stem of suffur) are enough, 33/4, suffices, pr $3 \mathrm{sg}, 25 / 14$, suff $\imath c y p$, pr $3 \mathrm{sg}$, $9 / 25$

sufficzent, adj (OF sufficient) sufficient, $7 / 17$

suffre, inf (AF suffrir) suffer (pain), allow, 5/22, pr $1 \mathrm{sg}, 7 / 31, \mathrm{pr} \mathrm{pl}$, 19/19, pr sub] $2 \mathrm{sg}, 37 / 19$, suffred, $\mathrm{pp}, 35 / 24$, suffrede, pa sg, 3/1, 9/28, suffren, pr pl $13 / 22$

sugget see sogetes

sum, pron (OE sum) some, 11/23, 21/5, sum del see del, summe, $13 / 30$, sum tyme sometımes, 31/10, sum what, pron (ME) somewhat, $31 / 1$

sumned, Pp (OF sumon- stem of sumundre) call to account, call upon, $7 / 28$

sundur see on sunne see sonne sunner(e) comp of sone $\mathrm{q}$. suppose, inf (F supposer) suppose, $33 / 12$, pr $1 \mathrm{sg}, 23 / 12$, pr subj, $2 \mathrm{sg}, 25 / 12$

suptuouzs, adj (OF somptueux) costly, 27/9

surely, adv (OF sure $+1 \mathrm{y}$ ) securely, safely, $9 / 20$

surfet, sb (OF surfet) excess, 39/9, 28

suspescion, sb (AF suspecioun) suspicion, $27 / 14$

susteyne, inf (OF sosteyn-, pr stem of sustenır) support, $39 / 6$

sustınaunce, $\mathrm{sb}$ (AF sustenaunce) nourishment, 39/29

swan, sb (OE swan) swan, 27/25

sweerd, $\mathrm{sb}$ (OE sweord) sword, 39/10, sweerde, 5/35

swellinge, vbl sb (OE swellan) inflation through pride, 9/16

swepe, inf (ME, special development of OE swāpan) sweep, 19/26

swete, adj (OE swẽte) sweet, pleasant, $13 / 18,41 / 5$, swelnesse, sb (OE swètnes) sweetness, 41/17

swipper, adj (OE swipor) quick, nimble, 5/14

symnelle, sb (OF simenel) fine bread, $39 / 20$

symple, adj see simple

synne, sb (OE synn) sin, 21/4, 39/36, cf synnede, vb

\section{$\mathrm{T}$}

take, unf (ON taka, LOE tacan) take, $19 / 17$, take to durect one's attention to, 5/26, taken, pp, 23/34, 29/7. toke, pa $2 \mathrm{sg}, 15 / 7$

talede, pa $\mathrm{pl}$ (OE talıan) would speak of, gossip, 13/4

talke, inf (ME, connected with sb OE talu, cf Early Frisian talken) talk. $37 / 24$

tame, adj (OE tam) tame, 9/11

tasted, pa sg (OF taster) tasted, 41/7 tawt, pp (OE tǣcan) taught, 27/19. $39 / 8$

telle, inf (OE tellan) tell, 25/4, imp 
sg consider, 13/20, telltst, pr 2 sg tell, relate, $15 / 8$

temperaunce, sb (AF temperaunce) moderation, sobriety, 27/19

tempestis, sb $\mathrm{pl}$ (OF tempeste) tempests, 23/19

tepet, sb (EME tipet, $2 \mathrm{OE}$ tæpped) headache scarf, tippet, 39/3

teres, sb pl (OE tēar) tears, 23/15

teyzed, pp (OE tigan, non-WS *tēgan) tied, fastened, 9/13

the, pron (OE pe) you, see bou

thi, pron (OE pIn) your, 9/32, 13/17, $p_{i}, 3 / 3,4, p_{i n}$, disjunctive, 31/34, pyn, 3/3, 27/15, per, 27/25

thrng, sb (OE ping) thing, 5/18, ping. 7/11, 26, pinge, 7/6, pinges, $\mathrm{pl}$, $23 / 4,33 / 3$

thkeluth, pr 3 sg (ME) tıckles, 37/22

thl, conj (ON til) till, 25/5

tiraunt sb (OF tyrant) tyrant, 25/11, tyraunt, 23/35

to, prep adv (OE tō) to, 3/1, 8

to gedere, adv (OE tōgædere) together, $3 / 10,9 / 1$

toke, pa $2 \mathrm{sg}$ of take $\mathrm{q} \mathrm{v}$

ton, pe ton, num (OE pæt ān) the one. $9 / 1$

toty, adj (ME, from tot as in totter) dizzy, tipsy, 23/4

topere, pe topere, adj (OE pæt ōper) the other, $9 / 2$, see oper

toures, sb pl (OE torr, EME tour from $O F$ tor, tur) towers, $11 / 21$, towres, 23/23

towchede, pa sg (OF tuchier) touched, $41 / 13$

town, sb (OE tūn) town, 11/20, townes, $\mathrm{pl}, 11 / 18$

towres see toures

transformeth, pr $3 \mathrm{sg}$ (L transformāre) transforms, 37/10

tre, sb (OE trēow) tree, 41/13, 14, tree, $15 / 10$, treis, $\mathrm{pl}, 11 / 16$

tremblnp, pr 3 sg (OF trembler) trembles, $13 / 24$ tresory, sb (OF tresorie) treasury, 21/11

tresour, sb (OF tresor) treasure, 9/21

trewauntes, $\mathrm{sb} \mathrm{pl}$ (OF truant) 1dle beggars, vagabonds (but cf note), $23 / 7$

tribulacrones, sb pl (OF tribulacion) afflictions, 41/16

triste, imp sg (ON treysta and ME sb trust) trust, 9/33

trone, sb (OF trone) throne, 13/24

trubled, PP (OF trubler) contrite, mournful, 41/6

true, adj (OE trēowe) true, farthful, $25 / 20$, truly, adv (OE trëowlice) faithfully, 21/15

trussen, pr pl (OF trusser) pack, $27 / 23$

trupe, sb (OE trēow p) truth, 25/28

turne, inf (OE tyrnan, OF tourner) turn, change, 31/15, 41/17, turned, pp , 41/14

turnementes, sb pl (ONF torneyment) tournaments, 5/36

twres, num (OE twiges) twice, 25/23

two, num (OE twā) two, 23/4

tyme, sb (OE tima) time, 5/4

tymen, pr pl (OE getimian) prosper, $29 / 3$

tyraunt see trraunt

typingges, sb pl (LOE tiding, ON tipend1) important news, 13/21

\section{$\mathbf{P}$}

pak, sb (OE pæc) roof, 35/7

pan, conj (OE ponne, pænne) than, 23/36, 31/23, panne, conj adv than, then, $11 / 12,21 / 10$, pen, con] but, 19/18, penne, conj adv, 3/30, $25 / 1$

pank, sb (OE panc) thanks, 13/10

pank worthı, adj (ME) thankworthy. $3 / 16$

pankynges, vbl sb pl (OE pancunge) thanks, 31/3

pat, determ pron (OE pæt) that which, 25/20, 31/34 
pat, conj (OE pæt) that (used as a substitute instead of repeating a previous conjunction, cf OED, that, conj 8), 11/12, that (ntroducing a noun clause, cf $O E D$, that, conj 1), $3 / 3,13 / 19$, that (introducing an appositional clause, cf OED, that, conj 1b), $13 / 5(1)$, because (introducing a clause expressing the ground or reason of what is stated in the principal clause, of OED that, conj 2 [b]), 19/25, 21/5, after relatives and adverbs (cf OED, that, conj 6), 9/15, 18 See Points of Syntax, $\$ 77$

pat, dem pron (OE pæt) that, 5/12, $7 / 14$

pat, rel pron (OE pæt) who, which, $3 / 1,25 / 6$

pe see per

$p e$, def art (ENIE) the, 3/8, 27

pe, pron (obj) (OE pẽ) you, 3/4, 6 , the, 7/19, see bou

$p e+$ adv comp (OE py, pē) the, $11 / 7,8$, eueve $p e, 35 / 19$, reinforces a proportional comparative

pedur, adv (OE pider) thither, 31/21

pefes, sb pl (OE pēof) thieves, 9/21, peues, 27/4

per, poss pron see thr

$p e r$, pers pron (ON peir) they, 3/32, $5 / 1, p e, 37 / 22$, hem (OF heom, hım) them, $7 / 2,27 / 20$, hem, refl to themselves, $5 / 3$, hem self themselves, $3 / 31$, hym them, $15 / 18$

penken see prnke

$\operatorname{pen}(n e)$ conj adv see $\operatorname{pan}$

$\operatorname{per}(e)$ see her (their)

per, pret pres vb impers $3 \mathrm{sg}$ (OE pearf with loss of $\mathrm{f}$ ), per pe not be you need not be, $25 / 14$, derst, pret pres vb pr $2 \mathrm{sg}$. (OE dearr, durron), the sense 'need' is due to confusion with pearf, purfon, $27 / 13$

per, adv (OE pèr, pǣr) there, 23/33, $33 / 8$, pere, 25/18, 27/29, per affter see affter, per atte present, 35/1, per by through it, $19 / 24$, per fore therefore, 13/25, perfore for 1t, 9/19. per fro from 1t, $5 / 9$, pere inne in that, 5/21, per of of $1 t, 19 / 23,25 / 6$, per onne about that, $31 / 3$, per to for that purpose, $7 / 18$

pese, pron (OE pes, peos, p1s) these, $3 / 31,29 / 4$, pis this, $7 / 33,13 / 4$

peues see pefes

$p \imath(n)$ see thr and pou

ping(e), pinges see thrng

pinke, inf (OE pencan, pyncan) think, 27/30, finkep him, impers, 39/26, him pinkith, impers he thinks, 39/22, Penken, pr pl, 31/3

$p i n(n e)$, adj (OE pynne) thin, 37/2, 3 pis see pese

Pr self, $p$ i silff see self

pof, conj (ON pōh, OE pāh) though, 35/8, poou3, 7/2, poow, 7/11, 26. al poow, 33/26, pow, 19/13

porn, sb (OE porn) thorn, 19/25

poruz, prep (OE purh, porh) through, 25/26, porw, 11/11, 25/20

pou, pron (OE pū) you, 3/3, 12 , pou3, 19/18, 23/19, роw, 35/10, $p e$, obj (OE pè), 3/4, the, 29/12, pi, 21/4

pouz, pow see pou and pof

pouztes, sb pl (OE poht) thoughts, $23 / 33,25 / 7$

pral, sb (ON præ̈ll, OE præl) bondman, 23/35, praldam bondage, 21/17, praldom, 25/29

pre, num (OE prẽo, prle) three, $31 / 28$

preschfold, sb (OE perscold, ON preskjøldr) threshold, $35 / 6$

pridde, num (OE pridda) third, 9/16 prife, pr sub] (ON prifask) thrive, $41 / 1$, pryuen, pr pl, 25/10

priste, inf (ON prȳsta) thrust, press, 27/21

pristi, adj (OE purstıg, pyrstıg) thirsty, 33/23

pryuen sce prife 
pus, adv (OE pus) thus, to such a degree, 5/9, 7/10

byn see thi

\section{V}

valer, sb (OF valée, $\mathrm{AF}$ pl valeys) valley, $23 / 15$

vante, sb (OF vanité) concelt, vanity, $13 / 4$

verret, adj (AF verral, verrey) true, genuine, $7 / 5,29 / 1$, verrey, 31/36, vernli, adv , 5/33, verily, 31/34

vevtu, sb (OF vertu) vurtue, strength, excellence, 3/20,19/24, vertues, pl, $3 / 16$

vertuosly, adv (AF vertuous $+\mathrm{ly}$ ) virtuously, 19/20

veyn, adj (OF vein, vain) vain, 37/25, veyn glorie, sb (OF vaine gloure) vainglory, $9 / 16$

victorie, sb (AF victore) victory, $5 / 29,7 / 4$

vilany, sb ( $\mathrm{F}$ vileinie) disgrace, discredit, 11/6, vilanye degradation, $37 / 11$

vitailles, sb $\mathrm{pl}$ (AF vitalle) food, 39/18, vitalles, $39 / 13$

visioun, sb (AF visioun) vision, 25/2, 5 visis, $\mathrm{sb} \mathrm{pl}$ (OF vice) vices, $37 / 5$

unable, adj (OF inhabile) unable, 21/7 un apt, adj (un- + L aptus) unsuited, $21 / 8$

vnbond, pa sg (OE unbindan) freed, delivered, 25/7

unborn in mulorn (un- $+\mathrm{OE}$ beran) born out of wedlock, 19/15

vndede, pa sg (OE undōn) unfastened, revealed, $25 / 5$

vnder, prep (OE under) under, 25/17. vndur, 13/24

vnkynde, adj (OE on(ge)cynde) ungrateful, 31/1

vnlawtul, adj (un- + ON lagu + $\mathrm{OE}$ full) unlawful, lllegal, 19/11, vnlawfull, adv llegitımately, 19/9

vnlık, adj (OE ungelic) unlıke, different, $19 / 12$ vnloke, inf (from $\mathrm{OE} \mathrm{sb}$ loc or from pp gelocen) unlock, 25/7

vnlusti, adj (ME) unattractive, 5/3

vnnepe, adv (OE unēape, unēpe) scarcely, 13/23, vnnepes (prec +- s), $13 / 30$

vnnoble, adj (ME, from F, L) not of noble rank, 11/3

vnresonable, adj (un- + OF resonable) not endowed with reason, 39/7

vnschaply, adj (OE ungesceaplice) misshapen, ugly, 3/11

vnsemeli, adj (ON üscemiligr) ugly, $3 / 1,19$, unsemelynesse, $\mathrm{sb}, 3 / 5$

vntıd, pp (OE huntian) hunted, 27/6 vord, ad] (OF vorde) empty, destitute, $23 / 29$

vouchep saf on, pr $3 \mathrm{sg}$ (AF voucher

$+F$ sauf) bestows on, 13/30

$v p$, adv (OE up, upp) up, 13/24, 25/13 vs see we

vsin, inf (OF user) use, 9/31; vse, imp sg practise, 19/26, inf, 31/8

\section{W}

waggeth, (ME, connected with $\mathrm{OE}$ wagian cf Sw wagga) shakes, sways, $23 / 21$

wakest, pr 2 sg (OE wacian) wake, 37/27, wakyng, pr part, 25/4

sualke, inf (OE walcan) walk, 23/31, pr subj $2 \mathrm{sg}, 27 / 15$

walles, $\mathrm{sb} \mathrm{pl}$ (OE wall, weall) walls, $27 / 14$

wan, con] (OE hwanne) when, 41/13, wanne, $3 / 13$, wen, $31 / 23$, wenne, $3 / 4$, whan, 5/6, 41/9, whanne, 3/32, $23 / 27$, when, 37/7, 33/note to 120 wand, sb (ON vendr) rod, cane, 9/10 wane, adj (OE wana) lackıng, 27/33 wante, inf (ON vanta) want, be lackıng, 33/3, wante, pr subj sg , $31 / 27$, wantede, pa $2 \mathrm{sg}, 15 / 22$, wantes, pr $2 \mathrm{sg}, 3 / 3$, want $p$, pr 3 sg (impers), 33/1

wantoun, adj (OE wan $+\mathrm{OE} p \mathrm{pp}$ togen) undisciplined, rebellious, $9 / 6$ 
warde, sb (OE weard) keeping, custody, 9/17

ware, were $(n)$, where see be, vb

warne, inf (OE warnlan) warn, 7/27 was, whas see be, $\mathrm{vb}$

wast, adj (OF wast) Idle, needless, $35 / 3$

wat see what

water, sb (OE wæter) water, $\mathbf{3 7 / 1 8}$, $39 / 37$, zateres, $41 / 11$

$w e$, pron (OE wẽ) we, 15/24, 39/29, vs, 5/9, 39/30

weddıt, pp (OE weddian) married, joined, coupled, $25 / 21$

wedlok, sb (OE wedlāc) matrımony, wedlock, 19/14

weel, adv (OE well) well, 5/3, 13/9, wel, 33/15, 37/4, wele, 25/10, in wel I haue aspied, 39/15, wete wele, 21/16, wel (e) intensifies the meaning of the verb, as per may wel lest with good reason, 27/22

wel, adj (OE well) well, 25/22

wenferande, pr part (OE wegfērende) travellers by the road $33 / 25$

werze, sb (OE weg) way, 37/4, weyze, $25 / 18$

werh $\imath$, pr $3 \mathrm{sg}$ (OE wegan) weighs, $23 / 28$, weyath, $23 / 24$

wele, sb (OE wela) wealth, 23/14, $31 / 20$

wele see wille and weel

welde, inf (OE weldan, wieldan) rule, gain, possess, $5 / 33$

welkome $p$, pr 3 sg (OE wilcumian) welcomes, $15 / 2$

welpe, sb (ME) wealth, 27/33

wen see wan

wene, pr $1 \mathrm{sg}$ (OE wènan) think, suppose, $35 / 21$

wente, pa 3 sg (OE wendan) went, $15 / 16$

weping, vbl sb (OE wèpan) weeping, $41 / 2$, wepith, pr $3 \mathrm{sg}, 29 / 3$

weve, adv (OE hwēr, hwǣr) where, $27 / 12,33 / 19$, wereof from what, $13 / 22$, where, $15 / 21,33 / 3$ were see $b e, \mathrm{vb}$

uerkes, sb pl (OE weorc) works, $33 / 26$

werkyng, vbl sb (ME, influenced by

sb ) activity, action, 31/15

werve, adj comp (OE wyrsa, ON verr1) worse, $27 / 5$, werst, adv sup (ON verst, OE wyrrest, wierst) worst, $27 / 25$

werres, sb $\mathrm{pl}$ (OF werre) wars, 29/1 wete, $1 \mathrm{mp} \mathrm{sg}$ (OE witan) know, realıze, 21/16, wrste, pa $\mathrm{pl}, 33 / 23$, wost (OE wāst) $2 \mathrm{sg}, 23 / 1$

wete, inf (OE wētan, wạtan) wet, steep in, $41 / 10$

wepur or, conj (OE hwæper) whether or , 13/12

wex, sb (OE weax) wax, 5/18

weyze see werze

weyth see $u e t h t p$

weyk, adj (ON velkr) weak, 33/29

whan see wan

whas see was

what, interr pron (OE hwæt) what, $7 / 25,9 / 31$, wat, interj lo, well, $23 / 19$, what so, indef rel pron whatever, $7 / 30$, what euere, 15/1, what so euer, whatever, $13 / 9$

wheel, sb (OE hwēol) wheel, 31/15, 16 when see wan

where see $b e, \mathrm{vb}$ and were, $\mathrm{adv}$

$w h$, adv (OE hwȳ) why, $3 / 11,31 / 8$

whrcch, $\mathrm{sb}$ (OE wecg) wedge, 25/3, rycches, $\mathrm{pl}, 9 / 17$

whrzs see wrse

while, conj (OE hwIl) while, 31/19, cf wilıs, while, sb whlle, $7 / 4,27 / 8$ whise see wrse

who, indef interr pron (OE hwã) who, $35 / 4$, who so, who ever, 23/21, 35/13, whom, (OE hwǣm) whom (rel ), 21/9, 37/17, whos, (OE bwæs and o from the nom ) whose (rel). $33 / 10$, wos, whose (rel ), 21/7

rerch, rel pron (OE hwylc) which, $13 / 11,41 / 15$

wrcked, adj (ME) wicked, 23/35, 


\section{GLOSSARY}

wikkıd, 9/10, wickidnes, sb , 19/16, $41 / 6$

wide, adv (OE wide) wide, 35/5

wrdwes, sb $\mathrm{pl}$ (OE widewe) widous, $33 / 22$

wit, sb (OE wlf) wife, 15/19

wrkkıd see wrcked

$w \imath l$ see $n y l$, also wrlle, inf

wilde, adj (OE wld) wild, 9/11, 13

wilfull, adv (OE wilfullice) willingly, of their own free will, $37 / 16$

wilis, conj (OE hwil + adv gen es) whule, $9 / 1,15 / 6$, of while

wille, sb (OE willa) w 1ll, 9/7, 23/26

wille, inf (OE willan) will, want, $35 / 22$, wille, aux $1 \mathrm{mp} \mathrm{sg}$ (to introduce a polite question), 33/5, wele, pr $3 \mathrm{sg}, 5 / 22$, wnl, pr $3 \mathrm{sg}$ in wnl nyl whether he likes it or not, 25/15, wol, pr $3 \mathrm{sg}, 15 / 5$, $35 / 12$, wole, pr $3 \mathrm{sg}, 5 / 4,25 / 15$, wolen, pr $\mathrm{pl}, 35 / 7$, wolt, pr $2 \mathrm{sg}$, $25 / 8$, nolde, pa sg did not want, $25 / 27$, wolde, pa $1 \delta 3 \mathrm{sg}$ would, wanted to, should like to, $3 / 3,5$, woldest, pa $2 \mathrm{sg}$ woldest pou suffre, if you would allow, 41/9

wrsdam, sb (OE wisdōm) wisdom, $19 / 15,31 / 28$, wisdom, $13 / 18$

wrse, ad] (OE wis) wise, 23/34, whizs, $35 / 12$, whise, 37/9, wrsest, sup, $9 / 18$

\section{unste see wete}

wit, sb (OE wit) intellect, understanding. $7 / 12,11 / 17$

with, prep (OE wip) with, $7 / 4$, in the sight of (OED with, prep 10), 23/11

with drawe, inf (ME) withdraw, 29/14, 31/5, with drawes, 9/26

with gnne, prep (OE wipinnan) within, in $5 / 4$

with ouzten, prep (OE wipūtan) without, 23/1, 27/33, w th owten, $35 / 4$

withstandep, pr $3 \mathrm{sg}$ (OE wipstandan) stands in the way of, $11 / 17$, whthstond $q$, intr , 3/5 witnessith, pr 3 sg (from OE sb witnes) attests, bears witness to, $11 / 10$

woman, sb (OF wifmann) woman, $11 / 10$, womman, 3/24, wymmen, $\mathrm{pl}$, $3 / 31$

wombe ful, sb ME, from OE wamb + ful) bellyful, 39/22

wonder, adv (OE wundor, ef $\mathrm{OE}$ adv dat pl wundrum) exceedingly, wondrously, $3 / 15$, wondur, 35/16

wonderful, adj (OE wundorfull) marvellous, surprising, $25 / 2$

wondes, sb pl (OF wund) wounds, $41 / 10$

wonen, inf, pr pl (OE wunian) dwell, live, $5 / 16,33 / 20$

wont, pp (OE gewunod) accustomed, used to, 33/14

woo, sb (OE wã) misery, 31/20

word, sb (OE word) word, proverb, $25 / 8$

wordlt see world

world, sb (OE worold) world, 23/21, $35 / 20$, worlde, $9 / 19,13 / 14$, worldes, gen sg, 27/33, wordh, ad] (OE woruldlic) worldly, secular, 15/6. $33 / 21$, worldli, 33/note to 121 worschepe, inf (from sb) honour. revere, 11/6, worschipe, 13/17 worschepe, sb (OE weorpscipe)

honour, reverence, esteem, 23/18, $33 / 30$, worschipfulli, adv , 15/2

worth, adj (OE weorp, wurp) valuable, worth, 9/10, 3/27

worth, adj (OF wurp $+y$ ) worthy, distinguished, of standing, 5/33, $11 / 5$, worthilı, adv with dignity, $13 / 16$

wos see who

wost see wete

wrastele, inf (OE *wræstlian) wrestle, 27/25, wrastlen, pr pl, 9/1, wrastelinges, $\mathrm{vbl} \mathrm{sb} \mathrm{pl}$ wrestling matches, $5 / 37$

wrecche, sb (OE wrecca) unfortunate person, 31/36 


\section{GIOSSARY}

wreten see writith.

writith, pr. 3 sg. (OE writan) writes, $39 / 29$; wrytı $p, 7 / 19,21 / 5$; wreten, PP., 39/9.

wrong, adv. (ON *wrangr, LOE wrang) wrong, $27 / 27$.

wrouzt, pa. pl. (OE wrohte) acted, 19/10; wrouzte, pa. sg., 25/30.

wryt, in holi (holy) wryt, sb. (OE writ)
Holy Writ, Scriptures, 19/18, 5/10. wycches see whicch.

wynde, inf. (OE windan) wind, 39/3. wynde, sb. (OE wind) wind, 31/11. wynes, sb. pl. (OE win) wines, 27/10. wynne ouzt of, inf. (OE winnan) get out of, struggle, 25/12.

wyte, to wyte, inf. (OE witan) to blame, in fault, 19/23. 
Abraham, Abraham, 19/5

Alısaundere, Alexander, 5/23

Amoun, Amnon, 3/25

Avthour, Arthur, 7/5

Austeyn, Augustine, 5/10

Arrstotele. Aristotle, 11/18, 21/5

Babiloun, Babylon, 25/4

Bedlem, 5/24, Bedleem, 11/20, Bethlehem

Crisostom, Chrysostom, 39/36

Crist, 9/21, 23/8, 10, 35/15, 25, Cristes, 41/10, Christ, Christ's

Danrel, Daniel, 25/5

Daund, David, 3/24, 5/27, 28, 15/17

Ector, Hector, $7 / 5$

Egıpt, Egypt, 25/23

Esaw, Esau, 19/3

German, St Germain, 37/21

Goly. Golıth, 5/29

Helyab, Eliab, 5/27

Hismalitis, the Ishmaelites, 25/23

Ierusalem, Jerusalem, 11/19

Iesse, Jesse, Isa1, 5/25

Iesu, Jesus, 15/23, 41/7

Iob, Job, 33/29, Job, 9/3, 23/1, 33/21

Isaak, Isaac, 19/4

Israel, Israel, 5/25, 41/12

Jerom, Jerome, 23/35, 37/21

$J o b$ see $I o b$
Joseph, Joseph, 25/23, 30

Josue, Josue, $7 / 4$

Judas Machabe, Judas the Machabee, $7 / 4$

Lucifer, Lucifer, 5/2, 11/12

Marath, Mara, 41/11

Moab, Moab, 11/12

Moyses, Moses, 41/13

Nabugodonosor, Nabuchodonosor, 25/2

Paule, Paul, 5/2, 7/19, 9/23, 30, 39/28

Pernylle, Petronilla, 9/28

Petzr, 5/2, Petre, 23/6, Peter, 9/27. Peter

Plato, Plato, 15/15, 23/34

Putrphar, Putiphar, 25/24

Rome, Rome, 11/19

Ruth, Ruth, 11/10

Sampson, Samson, $7 / 3$

Samuel, Samuel, 5/24, 15/18

Sauzel, Saul, 15/16

Thamar, Thamar, 3/24

Thare, Thare, 19/5

Tutus, Titus, 9/29

Tobye, Tobias, $9 / 3$

Tymope, Timothy, 39/29

Virgıl, V1rgil, 13/17

Ypocras, Hippocras, Hippocrates, $11 / 18$ 


\section{IN DEX}

Ackermann von Boehmen, Der, [24]

Acta SS Nerel et Achillel, 46

Adam the Corthusian, [7]

Adam the Scot (of I)ryburgh), [7], $[41], 45$

Adrianus Carthusianus, [23], [24], [25], [30], [36]

Aelfric, [38], 71

Aelred of Rievaulx, [6]

Alanus de Insulıs, [44]

Albertanus Brissiensis (da Brescia), [7], [47]

Alne, R , [25], [29]

An Alphabet of Tales, 51

Ambrose, St , [5], [41], [47]

Apocalypse, [8]

Apologeticus, [36]

Aquinas, T , [5], [6], [25], [45], [51], [56]

Aristotle, [17], [25], [34], [39], [51], [64], 48, 75

Arnoldus Roterodamus see van Ge1lhoven

Augustine, St , [5], [6], [7], [8], [9], [20], [22], [33], [40], [41], [42], [44], [51], [56], [64], 42, 43

Ayenbite of Inwyt, [52], 43, 45, 51

Azzo dı Correggio, [16], [35], [46]

Ball, S , [6], [10].

Barbaro, E , [60]

Basle see Councils

Beaufort, $\mathrm{H}$, [27]

Bede, [38], 45

Bekynton, T , [26]
Benjamin Minor, [5], [9], 67, 69

Bernard, Brother, [6]

Bernard, St, of Clarrvaux, [6], [7], [20], [25], 45

Blois, P, of (Petrus Blesensis), [7], [47], 45

Bildestone, N , [28]

Blodwell, J , [25]

Boccaccio, G , [20], [31]

Boethius, [17], [20], [25], [34], [37], [39], [40], [41], [42], [47], [48], [51], [59], 44, 49, 50

Bokenham, O , 63, 67

Bole, R , [29]

Boltz, V , [36]

Bonaventura, St , [7]

Book, The see Kempe

Book of Vices and Virtues, [33], [52], 52

Bosso, M , [54]

Bracciolin1, P , [27], [28], [54], [59], [63], [64]

Brant, S , [24]

Brent Eleigh, [10]

Brethren of the Common Life, [30]

Brompton, J , [8]

Bromyard, J , 43

Brotherhouse of Zwolle, [24], [30]

Brun, L , [29], [54], [63]

Bukwode, J , [26]

Buonaccorso da Montemagno see Montemagno

Burley, W , [20], [28], [36], [40], [41]

Bury, $R$ de, [27] $f$ 
Caen, $R$ de, [56], [58], [64], [65]

Capgrave, J , 51, 67

Carmen de Mundı Contemptu, [56], [64]

Catalogue of the Augustınıan Friars at York, [26]

Catholicon Anglicum, 4874

Cato's Distichs, 76

Celestina, La, [21], [24]

Central Midland Standard, $66 \mathrm{ff}$

Charles IV, [24]

Chaucer, [20], [21], [37], [47], [52], 44, $49,50,51,64,76$

Chronicon, [8]

Chrysostom, St John, [57], 46, 47, 52

Cicero, [39], [42], [44], [47], [48], [51], [55], [57], [59], [62], [64]

Clastun, J , [4], [10]

Cloud of Unknowing, [3], [5], [9], [11], $67,68,69$

Colman, T , [4], [10]

Compostellanus, $\mathrm{P}$, [41]

Conches, G de, [36], [40], [42], [52]

Consolatio Theologiae, [48]

Constance see Councils

Controversia Homınıs et Fortunae, [41]

Conversino da Ravenna see Ravenna

I Cor vi, 20 45, II Cor xi, 25-27 46 , II Cor $x 11,945$

Councils of Constance and Basle, [26]

Crantor, [47]

Cyprian, [47]

Dambach, J von (Joh de Tambaco), [39], [48]

Daniel, 1148

Daudin, J , [20], [23], [35]

De Anima, [6]

Decembrio, P C , [27], [29], [64]

De Compunctione Cordis, 52

De Consciencia, [5]

De Consciencia Aedificanda, [6]

De Consolatione Rationis, [41]

De Contemptu Mund1, [21], [54]

De Controversia Homins et Fortunae, [41]
De Creatione, [5]

Decretum Gratianı, $47 \mathrm{f}$

De Dignitate Conditionis Humane, [5]

De Dignitate Sacerdotum, [6]

I)e Doctrina Dicendı et Tacendı, [6]

De Duodecim Utılitatıbus Tribulacionis [7], [9], [47], 45, 46

De Felicitate et Visena Dialogus, [54]

De Felicitate Libr Tres, [54]

De Imagine et Simulitudine [5]

De Interiorı Domo, [6]

De Miseria Humanae Vitae, [54]

De Miseria Humanae Conditionis, [54]

De Nobilitate, [54], [56], [59]

Deonise Hid Diuinite, [7]

De Remedus Fortuitorum, [17], [35] ff $[40] \mathrm{f},[49], 50$

De Remedus (Utrusque Fortunae) passim

Deschamps, E , [52]

De Saeculo et Religione, [54]

De Spiritalı Amicitia, [6]

De Tolerandis Adversis Dialogus, [54]

De Vera Amicicia, [6]

De Vera Nobilitate, [56]

De Virı Felicitate, [54]

De Vita et Moribus Phlosophorum, [36], [41]

De Voluptate ac de Vero Bono, [54]

Devota Exercicia, [24], [30]

Devotio Moderna, [30]

Dial of Ahaz, [8]

Dialogue between Reason and Adversity, passim

Dialogus Anımae Conquerentis et Rationis Consolantis, [41]

Dionysius Carthusianus, [31]

Dit sıjn Seneka Leren, [36]

Dobson, Mrs J , [24]

Durant, P , [4], [10]

Easton, A , [28]

Ecclus , 76, xı 43, x1,1 44, xxx,1 $45, \times \times \times 1,2 \quad 45, x \times \times v 11,3451$

Elcgia de Diversitate Fortunae et Philosophiae Consolatione, [41] 
Elucidarium, 43

Ep Jacob1, 111,3 45

Ep Tit , 11,9-10 48

Estrif de Fortune et de Vertu, [41]

Exodus, xv,23-25 52

Expositio in Antidotorium see Platearius

Eyb, A von, [24]

Ezekiel, xvı1,20 47

Faz1o, B , [54]

Flores Doctorum, [4], [34], 42-47, 49-52

Fortunatus, 51

Franc, M le, [41]

Frulovisı, T L , [27]

Galatians, v,17 44

Gallıo, [41], [46]

Gellhoven, A van, [30]

Genesis, xxxv11,28 48

Germanus Antessiodurum, 51

Germanus Augustodunum, 51

Glossd Ordınarıa, 48

Gloucester see Humphrey

Goldwell, J , [25]

Good Wife Taught her Daughter, The, 52,76

Gregory IX, Pope, 48

Gregory, St , [17], 45, 49, 77

Grey, W , [27]

Griselda, Gnseldis, [20], [21] [27], [29], [31]

Gualterıus ab Insulıs, [43], [52]

Guanno da Verona, [27]

Guigo II, [7]

Gullaume de Conches see Conches

Guillaume de Machaut see Machaut

Handlyng Synne, 43

Hawes, S , 44

Henrıcus of Settımello see Settımello

Heraclitus, [18], [19]

Herne Hill, [10]

Herods, [8]

Herxen, D van, [24], [30]f

Hieronymus contra Iovinianum, [8]
Homılıarum in Evangelia I.ıbrı Duo, 49

Horace, [42], 50, 77

Horologium Sapientiae, [4]

Hoveden, $T$ of, [25]

How the Wise Man Taught his Son, 52,76

Hugo of St Victor, [5] $f$

Humphrey, Duke of Gloucester, [26], [29]

Innocent III, [21], [22], [54]

Isa , xxx, 2643

Isagogicon Moralis Disciplinae, [54]

Isıdore of Seville, [41], 52

Jacobus Magnus see Magnus

Jean de Montreull see Montreuil

Jerome, st , [8], [42], [47], [65], 45, $46,48,50$

Job, v, $648, \quad x \times 1 \times 11-13 \quad 50, \quad x \times x 1$, 16-22 50

Johannes von Saaz see Saaz

John Chrysostom see Chrysostom

John of Salısbury see Salısbury

John, Gospel of St , [8]

Juvenal, 42, 49, 77

Kempe, M , 67

I Kings, 1x 46, I Kings, xvi,6 44, I Kıngs, xvi1, 4 44, II Kıngs, xı1 43

Ladder of Foure Ronges, A, [7]

Ldvynham, R, 67

Legend of St Petronilla, 46

Leviticus, 11,11-12 52, 11152

Liber Consolationis et Consilı, [47]

Liber Extra, 48

Liber Platearı see Platearıus

Litil Tretys, A, 67

Lorens, Frere, [52]

Lydgate, J , [28], 46, 49, 50, 63

Lyra, $\mathrm{N}$ de, 45, 52

Machaut, G de, [37], [41]

Magnus, J , [36] 


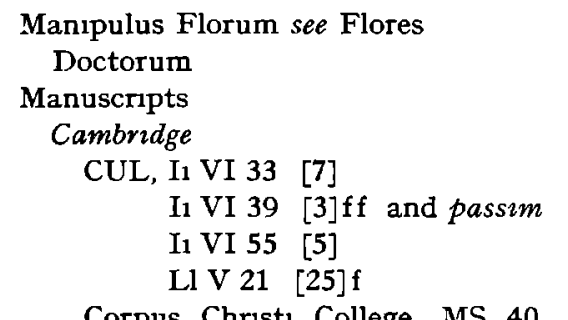

Corpus Christı College, MS 40 [25]

Peterhouse Library, MS 271 [25]

Dublin

Tnnity College, MS 432 (D 4 18) [6]

\section{London}

B M , Additional 10,342 [25]

Additional 14,808 [25]

Additional 27,336 [25], [36]

Arundel $286 \quad 45$

Arundel 334 [20], [25]

Arundel 507 [8]

Cotton Vespasian E XII [29]

Harley 674 [5], [11], 67, 68,69

Harley 1706 [7]

Harley 1883 [25]

Harley 2268 [26], [40], [41]

Harley 2570 [15], [25]

Harley 3346 [36]

Harley 3436 [41]

Harley 3579 [25]

Lansdowne 781 [15]

Royal 813 VI [29]

Lambeth Palace Library, MS 853 [6], 69

Westmuster School Library, MS

369

Oxford

Bodleian Library.

MS Douce 322 [7]

MS Rawlunson 455 [25]

MS Rawlinson C 8947

MS Vernon 45, 46

All Souls College, MS 91 [25]
Martın le Franc see Franc

Matth , 111 47, 1x,7 [57], 46, 47, $x \pm 1,13 \quad 43$

Meung, J de, [41]

Miracle of St Augustine at Compton, [8]

Moleyns, A de, [26]

Monte, $P$ del, [29]

Montemagno, $\mathrm{B}$ da, [54], [56]

Montreuil, J de. [20]

Moore, Bishop, [3], [10]

Moralıum Dogma Philosophorum, [36] [40], [42], [43], [51]

Vero, [41]

Newton, J , [25]

Niclas von Wyle see Wyle

Nola, Paulinus of, [47]

Norwich, Cathedral Priory, [26]

Oratio Thome de Alquin, [6]

Oresme, N , [24]

Otrynghain, J , [25]

Palmer(anus), T , [4], [34]

Pastıme of Pleasure, 44

Paston Letters, 67

Pearl, [47]

I Peter, 11848

Peterborough, [10], 69

Petrarch, passim

Africa, [63]

Canzoni, [30]

De Contemptu Mundi see Suum Secretum

De Otıo Religiosorum, [30]

De Remedus, passim

De Viris Illustribus, [29], [63]

De Vita Solitaria, [17], [29], [30], [31], [63], [64]

Epistulae Familiares, [19]

Historia Griseldis, [30]

Rerum Memorandarum, [29]

Rerum Senlium, [19]

Suum Secretum, [17], [29], [30]. [40], [43], [46], [54], [62], [64], [65]

Trionfi, [30] 


\section{N D E X}

Petworth, R, [28]

Phaedo, [42]

Physicke against Fortune, [24]

Piero del Monte see Monte

Pinicianus, J , [24]

Planctus Bonaventurae de Christo, [7]

Planctus Naturae, [44]

Platearius, J , [4]

Platina, B , [56], [64]

Plato, [42], [47], 46, 77

Poggio see Bracciolın

Poitıers, $P$ de, [19]

Prick of Conscience, [17], 51, 64

Promptorium Parvulorum, 48, 67

Proverbs of Alfred, 76

Proverbs, Book of, 76, x11,15 51, xvi1,5 51, xx11,22 51, xxx1,20 50

Pseudo-Petrarch, 31

Historia de Arono et Marina, [31]

Septem Psalmı Poenitentiales, [30]

Qudestiones in Vetus Testamentum, 52

Ravenna, C da, [54]

Remède de Fortune, [37], [41]

Remedia sive consolationes contra quedam adversa spintualibus accıdentia, [24]

Rolle, R , [25]

Richard of St Victor, [5]

Roger de Caen see Caen

Roja, F de, [24]

Roman de la Rose, [18], [37], 50, 51

Saaz, J von, [24]

Salisbury, J of, [20]

Salutatı, C , [54], [61], [63]

Scala Cel, , [7]

Scala Claustralıum, [7], [9]

Scala Paradisı, [7]

Secreta Secretorum, 42

Seneca, [17」, [35] ff , [39], [40], [44], $[46],[47],[48],[49],[57],[62], 42$, $43,44,46,47,48,49,50,51,52,74$, 77,79
Sermoun of Seynt Austın, [5], [9], 69

Settımello, $H$ of, [41]

Seville see Isıdore

Seward, J , [28]

Sixteen Points of Charity, [6]

Solıloquium de Instructione Animae, [41], 45

Somme des Vices et des Vertus, [52]

Sompnium Doctrinale, [30]

Sophologium, [36]

South English Legendary, 46

Spalatinus, G B , [24]

Specula omnis status humanae vitae, [31]

Speculum Christianı, 49

Speculum Historiale, [36]

Speculum Iuvenum, [31]

Stahel, P , [24]

Summa contra Gentıles, [51], [56]

Summa Predicantium, 43

Suso, H , [4]

Synonyma de Lamentatione Anımae Peccatricis, [41]

Talkıng of the Love of God, A, 70

Tambaco see Dambach

Tanner, $\mathrm{T}$, [7]

Teghen die strael der minnen see Pseudo-P'Ptrarch

Tertulhan, [36]

Thomas Aquinas see Aquinds

Thomas de Clifton (Thomasius de inglia), [28]

Thomas de Hibernia see Palmer

Thomas of Hoveden see Hoveden

I I Im v, 2346, v1, 852

Tretıs of Mayndenhod, [4], [9], 67, 69

Trevisa, J of, 64

Trostung in Widerwartigkeit, [24]

Twelve Profits of Tribulation, [47]

Twyne, T , [24], 43

Usk, T , [37]

Valerius Maxımus, [23], [32]

Valla, L , [54]

Vaucluse, [62] 


\section{N DEX}

Vegio, M., [54].

Vigilius, S., [24].

Vincent of Beauvais, [36]

Virgil, [42]

Vornken, W., [30].

Walsingham, T., [28].

Wanderer, The, [47].
Whethamstede, J., [29].

Whyttynton, R., [36].

Windesheim, [30].

Wyclif, J., [38], 49, 52, 64, 79.

Wycliffite Bible, [5], [9], 44, 69, 72.

Wyle, N. von, [24].

Zabarella, F., [54]. 

Het spreekwoord the more he has, the more he wants staat dichter bij multa petentibus desunt multa (Horatius, Carmina, III, 16, 24), bij whanne he most hath, most he failith (Romance of the Rose, middelengelse versie, regel 5720) en bij ...permultis eos indigere qui permulta possideant (Boethius, De Consolatione Philosophiae, II, Prosa v) dan bij de door A. Taylor gesuggereerde passage uit Ecclesiasticus v, 9.

Zie A. Taylor, The Proverb and an Index to the Proverb, 1962, p. 56.

II

Het humanisme van de Renaissance was, wat prestige betreft, de gouden eeuw van de A-faculteiten.

III

Petrarca's 'accidia' kan niet zonder meer vertaald worden met het Engelse 'sloth', maar vertegenwoordigt een verwereldlijking van de middeleeuwse kloosterziekte.

IV

De lage plaats die Matthew Arnold toekent aan Dryden en Pope in zijn classificatie van de Engelse dichters is, afgezien van de romantische achtergrond van zijn tijd, te verklaren uit zijn ideeën over 'culture'.

Zie M. Arnold, The Study of Poetry. 

De interessantste conclusie die $\mathrm{K}$. Heitmann bereikt in zijn boek Fortuna und Virtus is dat Petrarca geen duidelijk sluitend philosophisch systeem heeft gehanteerd.

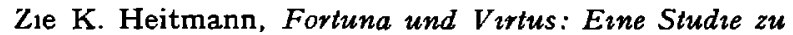
Petrarcas Lebenswershent. Studi Italiani, Band I, Koln und Graz, 1958.

VI

Het is wenselijk dat meer gedetailleerde studies van de middelengelse woordenschat de mogelijkheid vergroten deze gegevens als dialectcriteria te gebruiken.

\section{VII}

Moderne critische uitgaven van middeleeuwse florilegia, zoals de Communiloquium van John of Wales en de Manipulus Florum van Thomas Palmer, zouden een beter licht werpen op de belezenheid van middelengelse schrijvers.

\section{VIII}

In zijn editie van John Heywood's A Dialogue of Proverbs, 1963, p. 187 verkijkt R. E. Habenicht zich, taalkundig gezien, op Heywood's stylistische kwaliteiten, wanneer hij spreekt over diens 'sheer originality' en 'ad hoc' gebruik van actieve werkwoorden in een passieve betekenis (of vice versa) en van intransitieve werkwoorden in een transitieve betekenis. Dit zijn vrijheden die in het Renaissance taalgebruik veelvuldig voorkomen.

Zie F. Th. Visser, An Historical Syntax of the English Language, I, 1963, § 133 e.v. en $\S 163$ e.v.

IX

Het kan geen kwaad als in het bijvak ontwikkelingspsychologie voor toekomstige leraren relatief minder nadruk wordt gelegd op de kleuterjaren en meer op de puberteit.

$\mathbf{x}$

De weinig succesvolle resultaten wat betreft de toepassing van moderne literair-critische methoden op de middelengelse literatuur, zijn deels een gevolg van de aard van het materiaal zelf. 
Stellingen behorende bij F. N. M. Diekstra, A DIALOGUE BETWEEN REASON AND ADVERSITY, Nijmegen, 1968. 


$$
\begin{aligned}
& \text { 烃 }
\end{aligned}
$$

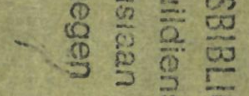

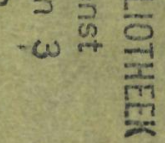


色 